Published bimonthly_January, March, May, July, September, November

Copyright 2000 by the Society for Range Man-agement

INDIVIDUALSUBSCRIPTION is by membership in the Society for Range Management.

LIBRARY or other INSTITUTIONAL SUBSCRIPTIONS on a calendar year basis are $\$ 95.00$ for the United States postpaid and $\$ 112.00$ for other countries, postpaid. Payment from outside the United States should be remitted in US dollars by international money order or draft on a New York bank.

BUSINESS CORRESPONDENCE, concerning subscriptions, advertising, reprints, back issues, and related matters, should be addressed to the Managing Editor, 445 Union Blvd., Suite 230, Lakewood, Colorado 80228.

EDITORIAL CORRESPONDENCE, concerning manuscripts or other editorial matters, should be addressed to the Editor, Gary Frasier, 7820 Stag Hollow Road, Loveland, Colorado 80538. Page proofs should be returned to the Production Editor, 445 Union Blvd., Lakewood, Colorado 80228.

INSTRUCTIONS FOR AUTHORS appear on the inside back cover of most issues. THE JOURNAL OF RANGE MANAGEMENT (ISSN 0022-409X) is published bimonthly for $\$ 56.00$ per year by the Society for Range Management, 445 Union Blvd., Ste 230, Lakewood, Colorado 80228. SECOND CLASS POSTAGE paid at Denver, Colorado and additional offices.

POSTMASTER: Return entire journal with address change - RETURN POSTAGEGUARANTEED to Society for Range Management, 445 Union Blvd., Suite 230, Lakewood, Colorado 80228.
Plant Ecology

211 Seasonal chemical composition of saltbush in semiarid grasslands of Jordan by Moh'd Khair J. El-Shatnawi, and Yaser M. Mohawesh

215 Grazing effects on spring ecosystem vegetation of California's hardwood rangelands by Barbara Allen-Diaz and Randall D. Jackson

\section{Plant Physiology}

221 Switchgrass growth and development: Water, nitrogen, and plant density by M.A. Sanderson and R.L. Reed

228 Effects of nitrogen fertilization in leafy spurge root architecture by Kirstin Ringwall, Mario E. Biondini, and Carolyn E. Grygiel

Soils

233 Rangeland management impacts on soil biological indicators in southern Alberta by Johan F. Dormaar and Walter D. Willms

\section{Improvements}

239 Broom snakeweed establishment following fire and herbicide treatments by K.C. McDaniel, D.B. Carroll, and C.R. Hart

Book Review

246 The Politics of Ecosystem Management, By Hanna J. Cortner and Margaret A. Moore; Carbon and Nutrient Dynamics in Natural and Agricultural Tropical Ecosystems, edited by L. Bergström and II. Kirchmann; The Pheasants of the World by Paul A. Johnsgard.

PRINTED IN USA

$\begin{array}{ll}\text { Managing Editor } & \text { Electronic JRM Editor } \\ \text { J. CRAIG WHITTEKIEND } & \text { M. KEITH OWENS } \\ \text { 445 Union Blvd., Ste 230 } & \text { Texas A\&MUniversity } \\ \text { Lakewood, Colorado 80228 } & \text { Research Center } \\ \text { (303) 986-3309 } & \text { 1619 Garner Field Road } \\ \text { Fax: (303) 986-3892 } & \text { Ulvade, Texas } \\ \text { e-mail address: } & \text { e-mail address: } \\ \text { srmden@ix.netcom.com } & \text { m-owens@tamu.edu } \\ \text { Editor/Copy Editor } & \\ \text { GARY FRASIER/JOFRASIER } & \text { Associate Editors } \\ \text { 7820 Stag Hollow Road } & \text { VIVIEN G. ALLEN } \\ \text { Loveland, Colorado 80538 } & \text { Texas Tech University } \\ \text { e-mail address: } & \text { Dept. of Plant \& Soil Science } \\ \text { gfrasier@lamar.colostate.edu } & \text { Box 42122 } \\ \text { Production Editor } & \text { Lubbock, Texas 79409-2122 } \\ \text { PATTYRICH } & \\ \text { Society for Range Management } & \text { YUGUANG BAI } \\ \text { 445 Unnion Blvd., Ste 230 } & \text { Kamloops Range Res. Sta. } \\ \text { Lakewood, Colorado 80228 } & \text { Agr. and Agri-Food Canada } \\ \text { e-mail address: } & \text { 3015 Ord Road } \\ \text { prich@ix.netcom.com } & \text { Kamloops, British Columbia } \\ \text { Book Review Editor } & \text { V2B 8A9 } \\ \text { DAVID L. SCARNECCHIA } & \text { CANADA } \\ \text { Dept of Natural Res. Sci. } & \\ \text { Washington State University } & \text { DAVID BELESKY } \\ \text { Pullman, Washington 99164-6410 } & \text { 1224 Airport Road } \\ \text { e-mail address: } & \text { P.O. Box 400 } \\ \text { scarneda@mail.wsu.edu } & \text { Beaver, West Virginia 25813 }\end{array}$

ROBERT R. BLANK
USDA-ARS
920 Valley Road
Reno, Nevada 89512
JOE E.BRUMMER
Mt. Meadows Res. Ctr.
P.O. Box 598
Gunnison, Colorado 81230
DAVID GANSKOPP
USDA-ARS
HC-71 4.51 HWY 205
Burns, Oregon 97720
ELAINE E. GRINGS
USDA-ARS
Fort Keogh-LARRL
Route 1, Box 2021
Miles City, Montana 59301
MARK JOHNSON
Louisiana State University
Forestry and WIIdlife Management
Baton Rouge, Louisiana 70803
WILLIAM H. MILLER
Arizona State University
School of Planning \&
Landscape Architecture
Tempe, Arizona 85287

PAULOHLENBUSCH Kansas State University Department of Agronomy Throckmorton Hall Manhattan, Kansas 66506

MICHAELH. RALPHS USDA-ARS

Poisonous Plant Lab $1150 \mathrm{E} 1400 \mathrm{~N}$ Logan, UT84341-2881

FAISALK. TAHA KISR-Aridland Agriculture Box 24885 13109 Safat KUWAIT

ALLEN TORELL New Mexico State University Agricultural Economics Box 3169 Las Cruces, New Mexico 88003

MIMI WILLIAMS

USDA-ARS

22271 Chinsegut Hill Rd

Brooksville, FL34601-4672 


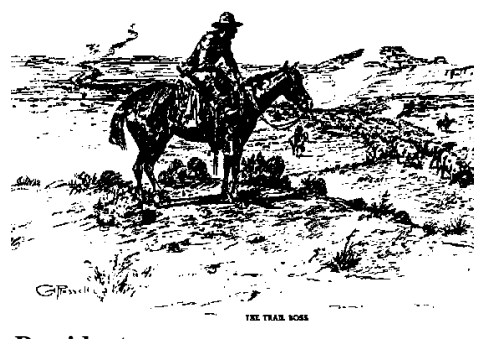

President

JOHN L. MCLAIN

340 N. Minnesota St.

Carson City, Nevada 89703-4152

1st Vice-President

JAMES T. O'ROURKE

61 Country Club Road

Chadron, Nebraska 69337

2nd Vice-President

Rodney K. Heitschmidt

USDA-ARS

Ft. Keogh LARRL

Rt 1, Box 2021

Miles City, Montana 59301-9801

Executive Vice-President

J. CRAIG WHITTEKIEND

445 Union Blvd. Suite 230

Lakewood, Colorado 80228-1259

(303) 986-3309

Fax: (303) 986-3892

e-mail address:

srmden@ix.netcom.com

\section{Directors}

1998-2000

PATRICK L.SHAVER

2510 Meadow Lane

Woodburn, Oregon 97071-3727

CAROLYNHULL SIEG

Forest \&Range Experiment Station

501 E. Saint Joseph Street

School of Mines Campus

Rapid City,South Dakota 57701-390

1999-2001

JAMES LINEBAUGH

3 Yhvona Dr.

Carson City, NV 89706-7717

GLENSECRIST

Idaho Dept. of Agriculture

3818 S. Varian Ave.

Boise, Idaho 83709-4703

2000-2002

RICHARDH. Hart

USDA-ARS

High Plains Grasslands Station

8408 Hildreth Rd.

Cheyenne, Wyoming 82009-8809

DONKIRBY

North Dakota State University

Animal \&Range Science

Fargo, North Dakota 58105

The term of office of all elected officers and directors begins in February of each year during the Society's annual meeting.
THE SOCIETY FOR RANGE MANAGEMENT, founded in 1948 as the American Society of Range Management, is a nonprofit association incorporated under the laws of the State of Wyoming. It is recognized exempt from Federal income tax, as a scientific and educational organization, under the provisions of Section 501(c)(3) of the Internal Revenue Code, and also is classed as a public foundation as described in Section 509(a)(2) of the Code. The name of the Society was changed in 1971 by amendment of the Articles of Incorporation.

The objectives for which the corporation is established are:

- to properly take care of the basic rangeland resources of soil, plants, and water;

- to develop an understanding of range ecosystems and of the principles applicable to the management of range resources;

- to assist all who work with range resources to keep abreast of new findings and techniques in the science and art of range management;

-to improve the effectiveness of range management to obtain from range resources the products and values necessary for man's welfare;

- to create a public appreciation of the economic and social benefits to be obtained from the range environment;

— to promote professional development of its members.

Membership in the Society for Range Management is open to anyone engaged in or interested in any aspect of the study, management, or use of rangelands. Please contact the Executive VicePresident for details.

The Journal of Range Management is a publication of the Society for Range Management. It serves as a forum for the presentation and discussion of facts, ideas, and philosophies pertaining to the study, management, and use of rangelands and their several resources. Accordingly, all material published herein is signed and reflects the individual views of the authors and is not necessarily an official position of the Society. Manuscripts from anyone-nonmembers as well as members-are welcome and will be given every consideration by the editors. Editorial comments by an individual are also welcome and, subject to acceptance by the editor, will be published as a "Viewpoint."

In Cooperation With: Some of the articles appearing in The Journal of Range Management (JRM) are presented in cooperation with The American Forage and Grassland Council (AFGC). This cooperation consists of $J R M$ acceptance of professional papers in forage grazing management and related subject areas from AFGC members and the appointment of 2 AFGC affiliated associate editors to JRM's Editorial Staff. The American Forage and Grassland Council Offices: P.O. Box 94, Georgetown, Texas 78627; Larry Jeffries, President; Dana Tucker, Executive Secretary.

Contribution Policy: The Society for Range Management may accept donations of real and/or personal property subject to limitations set forth by State and Federal law. All donations shall be subject to management by the Executive Vice President as directed by the Board of Directors and their discretion in establishing and maintaining trusts, memorials, scholarships, or other types of funds. Individual endowments for designated purposes can be established according to Society policies. Gifts, bequests, legacies, devises, or donations not intended for establishing designated endowments will be deposited into the SRM Endowment Fund. Donations or requests for further information on Society policies can be directed to the Society for Range Management, Executive Vice-President, 445 Union Blvd., Suite 230, Lakewood, Colo. 80228-1259. We recommend that donors consult Tax Advisors in regard to any tax consideration that may result from any donation. 


\title{
Are Namibia's grasslands desertifying?
}

\author{
DAVID WARD AND BEN T. NGAIRORUE
}

Authors are associate professor, Mitrani Department for Desert Ecology and Director, Ramon Science Center, Jacob Blaustein Institute for Desert Research, Ben Gurion University of the Negev, Sede Boqer 84990, Israel and Research Student, Desert Research Foundation of Namibia, 7 Rossini Street, Windhoek, Namibia.

\begin{abstract}
We compared the herbage standing crop on 31 farms along a rainfall gradient in Namibia (southwestern Africa) in 1997 with the results attained for the same gradient by Walter (1939). We found that the slope for the regression of herbage yield on mean annual rainfall in 1997 was 5.93 , i.e. $5.93 \mathrm{~kg}$ herbage was produced per hectare for every $1 \mathrm{~mm}$ increase in rainfall along the gradient. This regression slope is considerably lower than that in Walter's (1939) study (slope $=\mathbf{1 0 . 3 4}$ ). Thus, current grassland productivity per unit of rainfall in Namibia is about half that of 50 years ago. There is no evidence of a change in annual rainfall over this period, nor is there any evidence that either short-term (current) or longer-term (11 years) stocking densities affect current herbage yield. We conclude that, while desertification has taken place, grazing over the last decade has not been the cause of this reduced productivity.
\end{abstract}

Key Words: Africa, rangelands, historical records, grazing, rainfall

There is widespread concern over desertification (i.e. a longterm decline in productivity) of the semi-arid grasslands of the world (Schlesinger et al. 1990, 1996, Hall and Scurlock 1991, Strohbach 1992, Parton et al. 1995). However, it is often difficult to unequivocally determine whether desertification has occurred, because different types of information (e.g. on soil quality, carbon isotopes, vegetation quality and quantity) may give conflicting results (Hoffman et al. 1995, Parton et al. 1995, Parsons et al. 1997). Also, logistical problems such as variability in annual rainfall cause great natural fluctuations in herbage growth, making it difficult to differentiate pattern in declining productivity from noise caused by random or event-driven fluctuations (Hoffman and Cowling 1990, Sullivan 1996, Hoffman 1997, Ward et al. 1998, Ward et al. 1999). Long-term cycles in rainfall can further exacerbate this problem. For example, Hoffman and Cowling (1990) and Hoffman (1997) have shown that Acocks' (1953) claim that desertification was rampant in the semi-arid Karoo region of South Africa was probably caused by the long

We thank Japhet Karamata and Immanuel Kapofi for their assistance. We also thank the 31 farmers, the technicians at the Namibian weather bureau for their assistance, and the Namibian department of veterinary services for the provision of long-term stocking data. This study was funded by grant TA-MOU-94-C13-149 from the U.S. Agency for International Development to David Ward, Uriel Safriel and Mary Seely. This is publication number 287 of the Mitrani Department for Desert Ecology and publication number 88 of the Ramon Science Center.

Manuscript accepted 28 Jan 1999

\section{Resumen}

Se comparó el cultivo de pastoreo estable en 31 fincas a lo largo de un gradiente de precipitación en Namibia (sudoeste de Africa), en 1997, con los resultados obtenidos para el mismo gradiente por Walter (1939). Encontramos que la pendiente en la regresión para la producción de pasto en relacion con la precipitación media anual en 1997 fue 5.93, i.e. $5.93 \mathrm{~kg}$ de pasto es producido por hectarea en cada incremento de 1 mm en la precipitación a lo largo del gradiente. Esta linea de regresión es considerablemente más baja a la del estudio realizado por Walter (1939), (pendiente $=10.34$ ). De este modo, la actual productividad por unidad de precipitación en las praderas de Namibia es cercana a la mitad de la productividad hace 50 años. No hay evidencias de un cambio en la precipitación anual en este periodo de tiempo, ni hay alguna evidencia de que la densidad de la ganaderia a corto-plazo (actualmente) o a largo-plazo (11 años) afecten la producción de pastos. Concluimos que, mientras la desertificación ha tomado lugar, el pastoreo en la ultima decada no ha sido la causa de esta reducida productividad.

dry period in the 1950's. When one compares photographs of the vegetation taken in 1925 by I.B. Pole Evans with photographs taken at the same sites by Hoffman in 1993, it appears that vegetation cover has declined. However, if one compares Pole Evans' photographs to those taken in 1989 , one sees that no long-term change has occurred, since the 1920's and 1980's were similarly wet periods (Hoffman 1997).

Another major problem in assessing whether desertification has occurred is that few long-term data exist to define the past condition of grasslands. The grasslands of Namibia are notable exceptions to this. Walter (1939) examined the relationship between herbage production and average annual rainfall in Namibia (southwestern Africa) over a rainfall gradient of 100-500 mm. These data represent a baseline that can be used to make comparisons between production 58 years ago with the present day. Furthermore, because these data represent the relationship of grassland production with rainfall along a rainfall gradient, we can compare past productivity with that of today without having to concern ourselves with possible differences in rainfall between the sampling periods because the effects of variance in rainfall can be controlled by regression analysis. For these reasons, we attempt here to assess whether there have been significant changes in the productivity of Namibia's grasslands from the time of Walter's (1939) study and the present day. 


\section{Materials and Methods}

\section{Study sites}

In 1997 we studied herbage yield on 31 commercial farms in 3 clusters of 11,10 , and 10 farms, each within a $100 \mathrm{~km}$ radius of Otjiwarongo, Windhoek and Keetmanshoop, respectively (Fig. 1). All the farms were commercial and not communal farms, i.e. the possibility that the farms were in poor state due to the 'tragedy of the commons' (sensu Hardin 1968) or similar mechanism is unlikely. These 3 towns were chosen as the centers of our study for 2 important reasons: (1) long-term rainfall data exist, and (2) they are found along the length of a rainfall gradient from the dry southern part of Namibia (Keetmanshoop: mean \pm S.E. annual rainfall $=141.98 \pm 9.82 \mathrm{~mm})$, through central Namibia (Windhoek: mean + S.E. annual rainfall $=361.15 \pm$ $13.71 \mathrm{~mm})$ to the more mesic north (Otjiwarongo: mean + S.E. annual rainfall $=449.63+18.04 \mathrm{~mm}$ ) (Fig. 1). The vegetation in the northern region of this study is thornbush savanna, with varying degrees of dominance of thorn trees (mostly Acacia species) and perennial grasses (Van der Merwe 1983). Central Namibia is open dry savanna, also dominated by Acacia trees with a mixture of

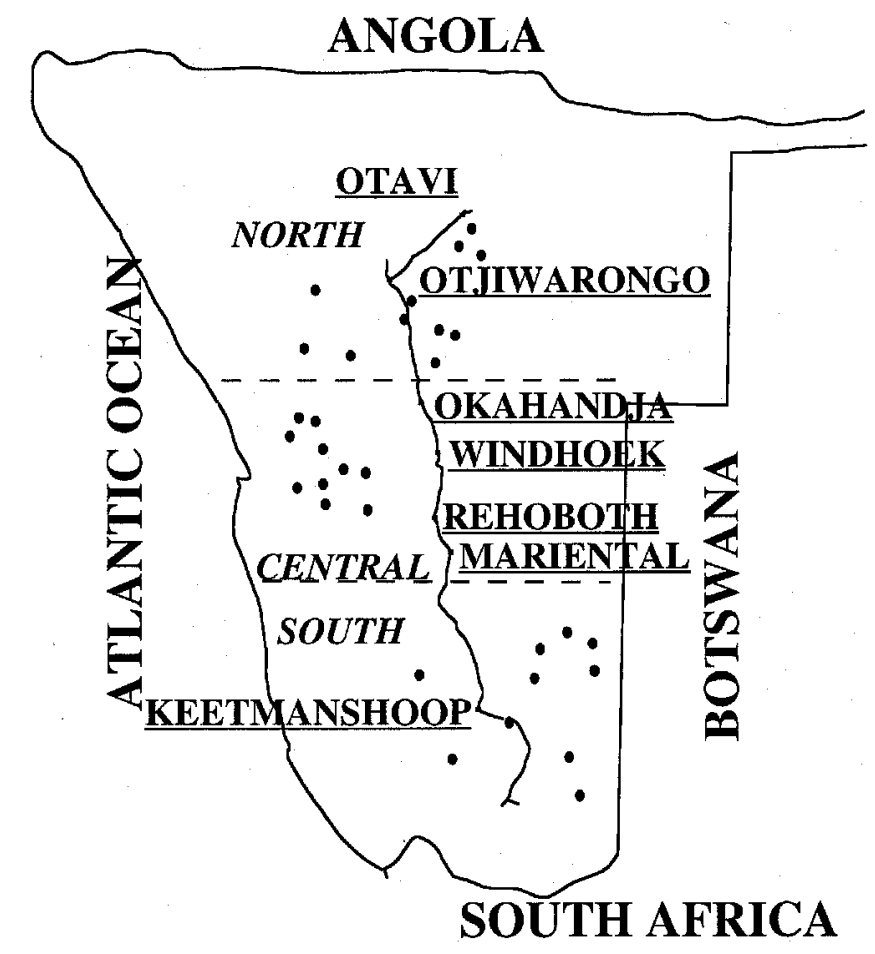

Fig. 1. Study sites on 31 farms in Namibia. Black circles indicate farm positions. annual and perennial grasses. Southern Namibia is covered by dwarf shrub savanna and open dry grasslands dominated by annual grasses. The only criterion for choosing farms within each of these regions was that long-term rainfall records were available for each farm from the Namibian national weather service. Stocking density for each farm was obtained either directly from the farmers (1997 season) or from the Namibian Department of Veterinary Services (longterm data). Long-term data are collected once a year for each by the Namibian Department of Veterinary Services for the purposes of disease control.

\section{Herbage measurements}

We used a point-frequency frame to measure herbage height (MuellerDombois and Ellenberg 1974) on the 31 farms. Note that we use the term 'herbage' here to denote all plant species that are not predominantly woody. In the main, these are grasses, but not entirely so. The study was done from the end of February to the middle of April 1997, the peak of the wet season in Namibia. On each farm, herbage height was measured at 3 points $20 \mathrm{~m}$ apart along the length of a gradient at 100 , $200,300,500$, and $1,000 \mathrm{~m}$ from stock watering points. This ensured that herbage height was measured from the worst to the best places on each farm as degradation around water points did not extend as far as $1,000 \mathrm{~m}$ from water on any farm (Ngairorue and Ward, Personal communication). Average herbage height from all these points was used to derive a single herbage height data point for each farm. Herbage height was converted to herbage mass $\left(\mathrm{kg} \mathrm{ha}^{-1}\right)$ from a regression where we measured herbage height using the pointfrequency frame and herbage mass by cutting, drying, and weighing herbage from a $1 \mathrm{~m}^{2}$ quadrat placed under the point-frequency frame. At each farm, sampling sites were chosen at random. The relationship between herbage mass and herbage height was defined by the equation:

Herbage Mass $\left(\mathrm{kg} \mathrm{ha}^{-1}\right)=10 *(4.17 *$ Herbage Height - 2.02); $\left(\mathrm{r}^{2}=0.88, \mathrm{P}<\right.$ $0.001)$.

\section{Soil quality}

We measured the following soil variables: organic carbon, total nitrogen, total phosphorus, $\mathrm{pH}$, conductivity, water-holding capacity. Soil was collected at 10-30 $\mathrm{cm}$ depth at the same 3 points used for the herbage biomass measurements, i.e. $20 \mathrm{~m}$ apart at each of the 5 distances from the waterpoints. These 3 samples were mixed to give a single value for each distance from the waterpoint. Organic carbon was measured as percentage mass loss on ignition at $400^{\circ} \mathrm{C}$ for 16 hours in a muffle furnace (Nelson and Sommers 1996). Total nitrogen was measured by conventional Kjeldahl techniques (Bremner 1996), and total phosphorus was measured with the Olsen technique (Olsen and Sommers 1982). Conductivity and $\mathrm{pH}$ were measured using $\mathrm{pH}$ and conductivity meters. Waterholding capacity was recorded as the percentage increase in mass of $10 \mathrm{~g}$ of dry soil when distilled water was added until the saturation point was reached. We also used radishes (Raphanus sativus Linneaus 1758) cv. Sparkler as a bioassay (total dry weight after 3 weeks) of soil nutrients (OlsvigWhittaker and Morris 1982).

\section{Statistical analyses}

We used conventional least-squares regressions to determine the relationships between herbage mass and rainfall. Residuals from these regressions were used to assess the effects of stocking density on herbage mass after the effects of rainfall differences among farms were removed. Multiple regressions were used to determine the effects of several independent variables such as soil nutrient parameters on herbage mass. Analyses of 
covariance were used to compare intercepts of regressions. Paired t-tests were used for paired data.

In addition to using least-squares regres sions to determine the relationship between herbage mass and rainfall, we also examined the maximal relationship between herbage mass and rainfall. In any relationship between productivity and a controlling environmental variable, one might expect that an 'envelope effect' exists (sensu Goldberg and Scheiner 1993). That is, there is a maximal (theoretical) relationship between herbage production and rainfall but in any single site a plethora of factors (not least of which is grazing) may skew this relationship downwards. No upwards skew can occur because there is a constraint placed by rainfall on herbage production over which additional herbage cannot be produced. We therefore expect an 'envelope' that describes a triangular cluster of data points below the regression line (Fig. 2). Such a relationship violates the assumption of conventional least-squares regression that there is homogeneity of variance (by definition, an 'envelope' results in greater variance at higher values of the independent variable). Thomson et al. (1996) describe a simple statistical test for an 'envelope effect': One first takes the positive residuals from the least-squares regression of the dependent and independent variables in question. These positive residuals are then regressed against the independent variable. The positive residuals of this new regression are taken and

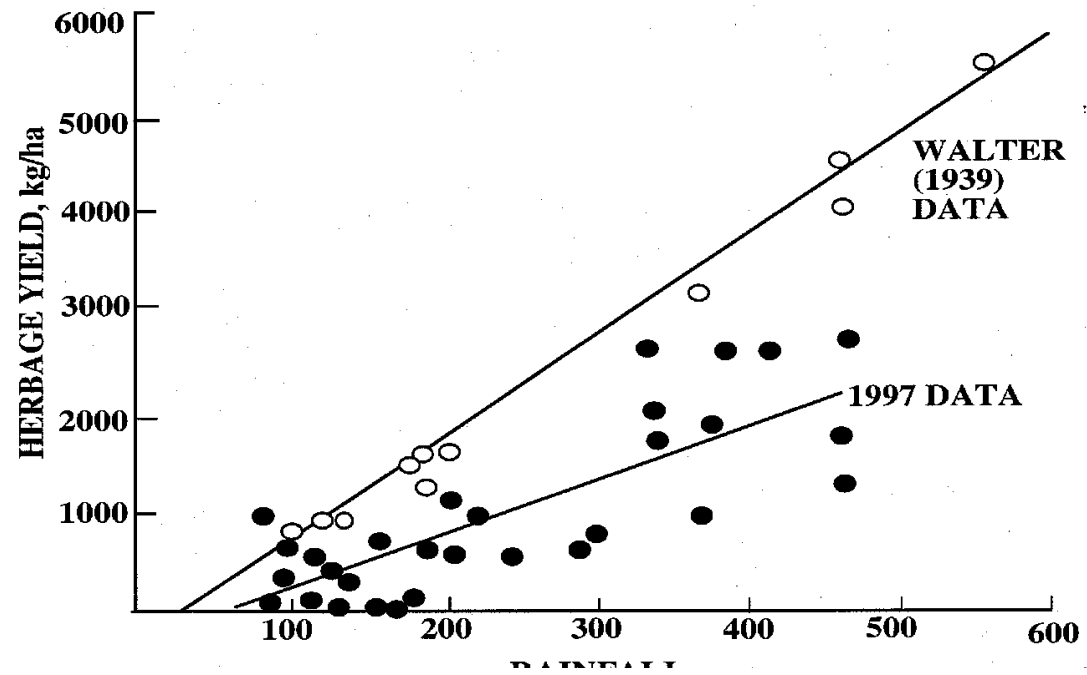

Fig. 3. Relationship between herbage yield $(\mathrm{kg} / \mathrm{ha})$ and mean annual rainfall $(\mathrm{mm})$ on 31 farms in Namibia. Walter's (1939) regression formula is: herbage yield $=10.34$ average annual rainfall - 401.3 (Rutherford 1980). Our regression for 1997 is: herbage yield $=\mathbf{5 . 9 3}$ average annual rainfall $\mathbf{- 3 2 8 . 5 5}$.

regressed against the original independent variable. This process is continued until the regression slope is no longer significantly different from zero. If there is indeed an 'envelope effect', the uppermost regression line (Fig. 2) will describe the upper limit to the 'envelope' (Thomson et al. 1996). If there is no envelope, the positive residuals will not be significantly related at any stage to the independent variable.

To test for possible cyclicity in longterm rainfall patterns, we used autocorrelation analyses. This is a statistical index that reveals the extent of the correlation between the residuals. The first-order autocorrelation is the conventional Pearson correlation of a series of numbers with the same series shifted by 1 year. This is then repeated for second-order (series shifted by 2 years), third-order (series shifted by 3 years), and further autocorrelations for as many years as there are in the series. Each correlation is tested for significance at the conventional level of $\alpha(0.05)$.

\section{Results}

\section{Herbage Yield}

The slope of the regression of current (1997) herbage yield per hectare on longterm average rainfall (herbage yield $=5.93$ average annual rainfall - 328.55) is far lower than that reported by Walter (1939) (herbage yield $=10.34$ average annual rainfall - 401.3) (following Rutherford 1980) (Fig. 3). More of the variance in average herbage yield is explained by variance in average annual rainfall $\left(\mathrm{r}^{2}=\right.$ $0.64, \mathrm{~F}=52.406, \mathrm{P}<0.0001$, error d.f. $=$ $29)$ than is explained by variance in the current season's rainfall $\left(\mathrm{r}^{2}=0.49, \mathrm{~F}=\right.$ 27.796, $\mathrm{P}<0.0001$, error d.f. $=29$ ).

We also regressed maximal herbage yield (i.e. where there was no grazing effect at a distance of 1,000 $\mathrm{m}$ from the waterpoint) against average annual rainfall at each site. The slope was steeper (herbage yield $=6.618$ average annual rainfall - 504.126, $\mathrm{r}^{2}=0.58, \mathrm{~F}=40.028, \mathrm{P}$ $<0.0001$, error d.f. $=29)$ than that for
Fig. 2. The 'envelope' effect in regression. Dots indicate individual data points, all of which are below the regression line that constrains the relationship. Note the heterogeneity of variance in the relationship; there is more variability on the right side of the $\mathrm{x}$-axis than on the left. 
average annual rainfall, although this difference was not significant (ANCOVA: F $=0.822, \mathrm{P}=0.368$, error d.f. $=59$ ). Indeed, there was no significant difference between herbage yield at 1,000 $\mathrm{m}$ from waterpoints and the herbage yield averaged over all distances from waterpoints on all the farms (paired t-test: $\mathrm{t}=1.671, \mathrm{P}$ $=0.105$, error d.f. $=30$ ).

Studies such as these could be biased by the logistical difficulties involved in sampling all sites simultaneously. For example, if all farms with high herbage yield were sampled at the end of the season after grazing, wind and other effects have reduced herbage yield, a significantly lower slope would be recorded for the herbage yield:rain regression. To test for bias produced by sampling date, we examined the correlation between the residuals of the regression of average herbage yield against average annual rainfall and sampling date. Because there was no significant correlation $\left(\mathrm{r}^{2}=0.01, \mathrm{~F}=0.339, \mathrm{P}=\right.$ 0.565 , error d.f. $=29)$, no effect of sampling date on the results is presented here.

It is possible that Walter's regression line represents a maximal relationship between herbage yield and rainfall (Rutherford 1980), and therefore our current regression line will lie through the average of the points below Walter's regression. We performed the procedure outlined above for testing for an 'envelope' effect and found that no such effect exists $\left(r^{2}=0.034, F=0.212, P=0.661\right.$, error d.f. $=6)$.

We also calculated the slope for maximal herbage yield against rainfall by regressing herbage yield for the two farms with the most positive residuals in the original least-squares regression against the independent variable (long-term average rainfall). In doing so, we created the maximal regression for our 1997 data. This regression (herbage yield $=8.49$ average annual rainfall - 110.87) was still $20 \%$ lower than that of Walter (1939).

\section{Stocking densities}

To test for the effects of grazing pressure on herbage yield, we took the residuals from the regression between herbage height and average annual rainfall (Fig. 3) and regressed them against current stocking densities [expressed in Large Stock Units (LSU) per hectare $]^{1}$. This regression removed the effect of variance in rainfall, and allowed us to directly examine the effects of stocking density on herbage yield. There was no significant relationship between these two variables $\left(\mathrm{r}^{2}=\right.$ $0.006, \mathrm{~F}=0.181, \mathrm{P}=0.674$, error d.f. $=$

NAMIBIAN HERBAGE PRODUCTION VS. STOCKING RATE

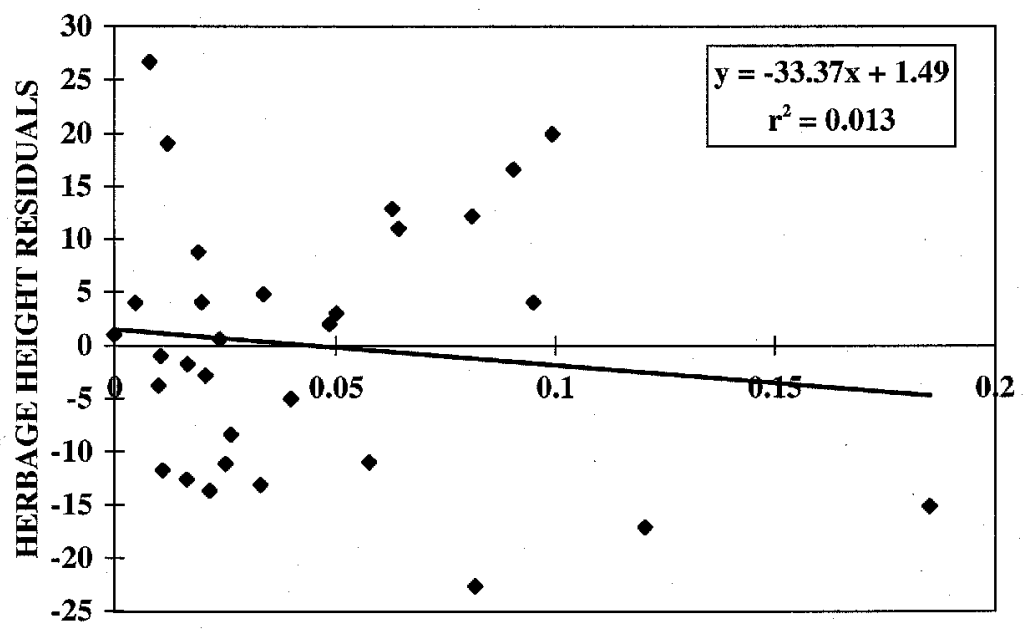

MEAN LONG-TERM STOCKING RATE, LSU/ha

Fig. 4. Relationship between residuals of herbage height vs. mean annual rainfall and mean long-term stocking rate (LSU/ha).

29), nor between the residuals of herbage height and long-term stocking densities (data from 1986-1996) $\left(\mathrm{r}^{2}=0.013, \mathrm{~F}=\right.$ $0.384, \mathrm{P}=0.540$, error d.f. $=29-$ Fig. 4$)$.

\section{Soil variables}

We tested for the effects of variance in soil variables on herbage yield after the confounding effect of average annual rainfall was removed. We used a multiple regression with the residuals of herbage yield as the dependent variable and organic carbon, total nitrogen, total phosphorus, water-holding capacity, $\mathrm{pH}$, conductivity, and total dry mass of radishes from the bioassay as independent variables. There was no significant effect of any of the soil variables on herbage yield $(\mathrm{F}=0.856, \mathrm{P}=$ 0.554 , error d.f. $=23$ ).

\section{Changes in rainfall over time}

Our study was conducted in an average rainfall year for the region. Mean \pm S.E. $\%$ of seasonal (1996/1997) rainfall was 231.8 $\pm 29.61 \mathrm{~mm}(\mathrm{c} . \mathrm{v} .=0.72)$ while long-term average rainfall for all 31 farms was 240.4 $+21.94 \mathrm{~mm}$ (c.v. = 0.52). Thus, 1996/1997 season rainfall was $96.4 \%$ of the long-term average. This difference was not significant (paired t-test, $\mathrm{t}=0.524, \mathrm{P}=0.604$, error d.f. $=30$ ).

We tested whether long-term rainfall changes might have led to the decline in production that we recorded compared to

\footnotetext{
${ }^{1}$ A Large Stock Unit is the equivalent of a single mature cow or 6 goats or sheep (Meissner et al. 1983).
}

Walter (1939). There was no significant change in rainfall at any of the 3 long-term rainfall stations (Otjiwarongo, Windhoek (Fig. 5) and Keetmanshoop). Declines could potentially be recorded because measurements were made at the low point in a rainfall cycle. We tested for the presence of rainfall cycles by autocorrelation analyses. Only at the Windhoek station was there any evidence of a cycle $(\mathrm{P}<$ 0.05 ), and this cycle is just 2-years long. Hence, the results we have for herbage yield are not a result of being in the low point of a long-term rainfall cycle.

\section{Discussion}

There is currently much concern in Namibia about the effects of various agricultural practices on productivity of the land (Quan et al. 1994, Seely and Jacobson 1994, Bester 1995, Ward 1996, Aharoni and Ward 1997). Indeed, about $60 \%$ of northern Namibia suffers from bush encroachment, while up to $90 \%$ of southern Namibia is considered to be overgrazed (Quan et al. 1994). However, statistics such as these do not tell us whether these problems are leading to long-term degradation. Thus, results such as ours form an important baseline to determine whether land degradation, and hence desertification, is occurring.

Our conclusion clearly rests on the validity of Walter's (1939) data. In making such a comparison, it is necessary to ensure that all possible confounding variables are controlled, which we have 


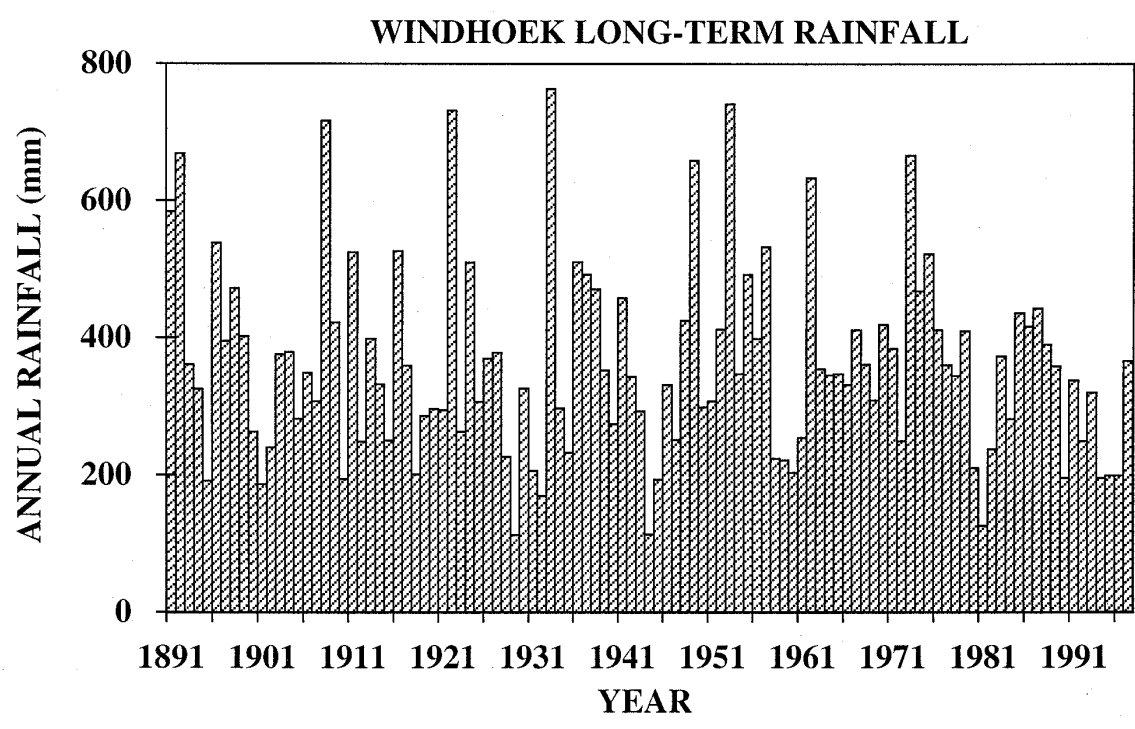

Fig. 5. Long-term rainfall patterns at Windhoek. There has been no significant change in rainfall over the period of measurement $(r=0.095, F=0.938, P=0.335$, error d.f. $=103)$. Data from the Namibian National Weather Bureau.

attempted to do in our study. Importantly, we have demonstrated that variation due to soil type and grazing regime over the last 11 years was not correlated with herbage height (and by inference with biomass) on the 31 farms. Furthermore, we have shown that more of the variance in herbage yield can be explained by longterm average rainfall than by seasonal rainfall. Thus, it is appropriate that we and Walter (1939) used long-term average rainfall as the independent variable in the regression with herbage yield. This conclusion is inconsistent with Rutherford's (1980) claim that annual rainfall has a greater effect on grassland productivity than long-term average rainfall. Rutherford (1980) concluded that only annual grasslands should have been used in Walter's (1939) study to allow for a direct relationship with annual rainfall. We consider this point to be unnecessarily restrictive because grasslands tend to change from annual to perennial grasses with increasing rainfall (Shmida 1985), thereby precluding appropriate comparison along the rainfall gradient in Namibia. Additionally, annual grasses tend to replace perennial grasses in desertified grasslands, especially those suffering from heavy grazing (Kelly and Walker 1977, Frost et al. 1986, O'Connor 1991, O'Connor and Pickett 1992, Seely and Jacobson 1994, Parton et al. 1995, Parsons et al. 1997).

A possible reason for the reduced productivity (identified by the lower regression slope of herbage yield:rainfall) in our data compared with that recorded by Walter (1939) is that Walter's regression line represents a maximum, rather than an average relationship as suggested by Rutherford (1980). Indeed, Whittaker and Marks (1975) found the low variance in Walter's relationship "remarkable". We note the very low variance about the regression line (Fig. 3). We consider it parsimonious to conclude that some degree of data "smoothing" was done by Walter (1939). We tested whether the reduced productivity in 1997 was due to comparison of our average regression relationship with a possible maximal relationship described by Walter (1939). We did this by regressing herbage yield for the 2 farms with the most positive residuals (in the herbage yield: average rainfall regression) against rainfall to produce a maximum slope. We still found that our data lay below those of Walter (1939). We believe, therefore, that even "smoothing" of the data by Walter cannot account for the lower slope of the regression in the current data. We noted that the maximal slope in our data (8.49) is very similar to Deshmukh's (1984) regression compiled for data from a wide range of sites in eastern and southern Africa, viz. herbage yield $=8.488 *$ rainfall -195.768 . This similarity in slopes suggested to us that Namibian herbage production may once have been similar to that described by Deshmukh (1984), but that it has now declined to an average slope of 5.93 (Fig. 3).

\section{Desert-grassland transition}

Rutherford (1980) used Seely's (1978a, b) data to justify a claim that a slope of about 5 was "normal" for southern African grasslands [Seely's regression equation was: Plant Production $\left(\mathrm{kg} \mathrm{ha}^{-1}\right)=5.48 *$ Seasonal Rainfall (mm) - 113.0], and also for his claim that it is only appropriate to use this year's rainfall and annual grasses. However, Seely's data are at the low end of the rainfall scale $(<100 \mathrm{~mm}$ rain per annum), and annual grasses only occur there. We believe that it is prudent to consider there to be a piecewise regression relationship (rather than a linear one) between herbage production and rainfall. That is, from $20 \mathrm{~mm}$ up to about $100 \mathrm{~mm}$ of annual rainfall, herbage production (annual grasses only) increases by about 5 $\mathrm{kg} / \mathrm{ha}$ for every $1 \mathrm{~mm}$ increase in annual rainfall (because $5.48=$ slope of Seely's equation). Above $100 \mathrm{~mm}$ annual rainfall, the perennial grass component increases as rainfall increases. This increase in the proportion of perennial grasses produces an increase in the standing crop of grasses per unit of rainfall because perennial grasses remain in the grassland even in low rainfall years. Thus, the slope of the herbage yield:rainfall regression should become steeper with annual rainfall exceeding 100 $\mathrm{mm}$. In undegraded situations, we tentatively suggest that this slope should be about $8 \mathrm{~kg} \mathrm{ha}^{-1}$ for every $1 \mathrm{~mm}$ increase in average annual rainfall, i.e. the slope (8.488) derived by Deshmukh (1984) for a wide range of undisturbed eastern and southern African sites. From our results, it appears logical to consider long-term average annual rainfall as the major factor affecting herbage production above 100 $\mathrm{mm}$ annual rainfall and actual annual rainfall below this amount. Thus, we consider both Walter (1939) and Seely (1978a, b) to be correct in their choices of the independent variables, and therefore disagree with the choice advocated by Rutherford (1980).

We therefore return to our original question: Are Namibia's grasslands desertifying? We conclude in the affirmative. The level of productivity per unit rainfall is considerably lower than that previously measured. Identification of the causes for this decline in productivity is needed so that appropriate management strategies can be developed for the sustainable use of these rangelands, especially because current stocking densities do not seem to have an effect.

O'Connor (1985) analyzed long-term experiments in southern Africa on the effects of rainfall and grazing on state variables but he found no evidence that changes in rainfall patterns have caused a major change in any system. Cyclic changes in grassland composition have 
followed rainfall cycles, i.e. grassland composition has been nearly constant for any particular rainfall condition and all species eliminations have been of a temporary nature only. He concluded that long-term rainfall variability, independent of rainfall regime, has an overriding effect on grassland compositional trends. The cumulative effects of grazing, however, do influence the rate of rainfall-induced compositional changes (O'Connor 1985). This conclusion is consistent with Bester's (1995) claim that the major cause of rangeland degradation in Namibia is the overestimation of the annual forage production, resulting in overutilization of the rangeland.

Our data on short-term (current season) and longer term (11 years) stocking densities are inconsistent with these claims. We found no evidence for changes or longterm cycles in rainfall, and no effects of stocking densities on biomass. This result does not mean that grazing has not affected the botanical composition of the rangelands. Grazing may affect botanical composition in semi-arid and arid rangelands (Landsberg et al. 1997, 1999). Milchunas and Lauenroth (1993) found that there was a positive correlation between the degree of grazing-induced change in botanical composition and mean annual rainfall, although increasing evolutionary history of grazing produced increasing dissimilarity in species composition between grazed and ungrazed sites regardless of the level of precipitation. A grazing-induced change in botanical composition may cause an indirect decline in productivity if the original species had higher biomasses than the current species. However, if this were the case, it would still be possible to detect a decline in productivity by the regression approach we used. Furthermore, due to the absence of such data in Walter's (1939) study, no comparison can be made between the botanical composition along this environmental gradient in 1939 and the composition in our study.

We suggest that while stocking densities have been the cause of the lowered herbage production in Namibia, this effect is very gradual and takes more than the 11 years to manifest itself. In another study in the central part of the rainfall gradient in Namibia, Ward et al. (1998) found that 10fold differences in stocking rates over the short- to medium-term ( $1-50$ years) did not cause detectable differences in herbage yield or soil quality. However, a decline in herbage productivity was discerned when comparing sites known to have had heavy grazing for the last 150 years with similar sites that have experienced only 5-10 years of heavy grazing. Wiegand and Milton (1996) have shown by spatiallyexplicit modeling in the arid Karroo of South Africa that simulated overgrazing of a rangeland in good initial condition only became obvious 40 or 50 years after the initiation of heavy grazing, and after 70 years the mean vegetation state eventually reached that of an overgrazed rangeland. Both Wiegand and Milton's (1996) and our (Ward and Kapofi 1999, Personal communication) results point to the extremely long-term nature of declining productivity or desertification brought about by heavy grazing in such arid habitats. It is clearly necessary that future research programs establish long-term sampling plots along the rainfall gradient in Namibia to determine whether slow long-term degradation is occurring, as appears to be the case from the results presented here.

\section{Literature Cited}

Acocks, J.P.R. 1953. Veld types of South Africa. Mem. Bot. Surv. So. Afr. 28:1-192.

Aharoni, B. and D. Ward. 1997. A new predictive tool for identifying areas of desertification that combines Principal Components Analysis and Geographical Information Systems: a case study from Namibia. Desert. Control Bull. 31:12-18.

Bester, F. 1995. Drought and rangeland management. p. 91-104. In: R. Moorsom (ed). Coping with aridity: drought impacts and preparedness in Namibia. Brandes and Appel/NEPRU: Windhoek, Namibia.

Bremner, J.M. 1996. Nitrogen - total. p. 1085-1121. In: D.L. Sparks (ed). Methods of soil analysis. Part 3 - Chemical methods. Soil Science Society of America, Madison, Wisc.

Deshmukh, I.K. 1984 . A common relationship between precipitation and grassland peak biomass for East and southern Africa. Afr. J. Ecol. 22:181-186.

Frost, P.G.H., J.C. Menaut, B.H. Walker, E. Medina, O.T. Solbrig, and M. Swift. 1986. Responses of savannas to stress and disturbance. Biol. Internat. 10:1-82.

Goldberg, D.E. and S.M. Scheiner. 1993. ANOVA and ANCOVA: Field competition experiments. p. 69-93. In: S.M. Scheiner and J. Gurevitch (eds). Design and analysis of ecological experiments. Chapman and Hall, London.

Hall, D.O. and J.M.O. Scurlock. 1991. Climate change and productivity of natural grasslands. Annals Bot. 67 (suppl.):49-55.

Hardin, G. 1968. The tragedy of the commons. Sci. 162:1243-1248.

Hoffman, M.T. 1997. Human impacts on vegetation. p. 507-534. In: R.M. Cowling, D.M. Richardson and S.M. Pierce (eds). Vegetation of southern Africa. Cambridge Univ. Press, Cambridge.
Hoffman, M.T. and R.M. Cowling. 1990. Vegetation change in the semi-arid eastern Karoo over the last two hundred years: an expanding Karoo - fact or fiction? So. Afr. J. Sci. 86:286-294.

Hoffman, M.T., W.J. Bond and W.D. Stock. 1995. Desertification of the eastern Karoo, South Africa: conflicting palaeological, historical and soil isotopic evidence. J. Environ. Monit. Assess. 37:159-177.

Kelly, R.D. and B.H. Walker. 1977. The effects of different forms of land use on the ecology of the semi-arid region in south-eastern Rhodesia. J. Ecol. 62:553-576.

Landsberg, J., C. James and S. Morton. 1997. Assessing the effects of grazing on biodiversity in Australia's rangelands. Aust. Biologist 10:153-162.

Landsberg, J., T.G. O'Connor, and D. Freudenberger. 1999. The impacts of livestock grazing on biodiversity in natural ecosystems, pp. 752-777. In: H.J.G. Jung and G.C. Fahey. (eds.). Nutritional ecology of herbivores. Amer. Soc. of Anim. Sci., Savoy, Ill.

Meissner, H.H., H.S. Hofmeyr, W.J.J. Van Rensburg, and J.P. Pienaar. 1983. Classification of livestock for realistic prediction of substitution values in terms of a biologically defined large stock unit. Tech. Comm. 175. Dept of Agr, Pretoria, So. Africa.

Milchunas, D.G. and W.K. Lauenroth. 1993. Quantitative effects of grazing on vegetation and soils over a global range of environments. Ecol. Monogr. 63:327-366.

Mueller-Dombois, D. and H. Ellenberg. 1974. Aims and methods of vegetation ecology. Wiley, New York.

Nelson, D.W. and L.E. Sommers 1996. Total carbon, organic carbon, and organic matter, pp. 961-1010. In: D.L. Sparks (ed). Methods of soil analysis. Part 3 - Chemical methods. Soil Sci. Soc. of Amer., Madison, Wisc.

Ngairorue, B.T. and D. Ward. 1999. Grazing, rainfall and soil impacts on farms along a rainfall gradient in arid Namibia. In Prep.

O'Connor, T.G. 1985. A synthesis of field experiments concerning the grass layer in the savanna regions of southern Africa. South African Nat. Sci. Prog. Rep. 114. CSIR, Pretoria, So. Africa.

O'Connor, T.G. 1991. Local extinctions in perennial grasslands: a life-history approach. Amer. Nat. 137:753-773.

O'Connor, T.G. and G.A. Pickett. 1992. The influence of grazing on seed production and seed banks of some African savanna grasslands. J. Appl. Ecol. 29:247-260.

Olsen, S.R. and L.E. Sommers. 1982. Phosphorus. p. 403-430. In: A.L. Page, A.L. (ed). Methods of soil analysis. Part 2. Soil Sci. Soc. of Amer, Madison, Wisc.

Olsvig-Whittaker, L. and J.W. Morris. 1982. Comparisons of certain Nylsvley soils using a bioassay technique. So. Afr. J. Bot. 4:91-96.

Parsons, D.A.B., C.M. Shackleton and R.J. Scholes. 1997. Changes in herbaceous layer condition under contrasting land use systems in the semi-arid lowveld, South Africa. J. Arid Environs. 37:319-329. 
Parton, W.J., J.M.O. Scurlock, D.S. Ojima, D.S. Schimel, D.O. Hall and SCOPEGRAM members. 1995. Impact of climate change on grassland production and soil carbon worldwide. Global Change Biol. 1:13-22.

Quan, J., J. Barton and C. Conroy. 1994. A preliminary assessment of the economic impact of desertification in Namibia. D.E.A. Research Discussion Paper 3. Dept. Environmental Affairs, Windhoek, Namibia.

Rutherford, M. 1980. Annual plant production-precipitation relations in arid and semiarid regions. So. Afr. J. Sci. 76:53-56.

Schlesinger, W.H., J.F. Reynolds, G.L. Cunningham, L.F. Huenneke, W.M. Jarrell, R.A. Virginia and W.G. Whitford. 1990. Biological feedbacks in global desertification. Sci. 247:1043-1048.

Schlesinger, W.H., J.A. Raikes, A.E. Hartley and A.F. Cross. 1996. On the spatial pattern of soil nutrients in desert ecosystems. Ecol. 77:364-374.

Seely, M.K. 1978a. Grassland productivity: the desert end of the curve. So. Afr. J. Sci. 74:295-297.

Seely, M.K. 1978b. Standing crop as an index of precipitation in the central Namib grassland. Madoqua 11:61-68.
Seely, M.K. and K. Jacobson. 1994. Desertification and Namibia: a perspective. Afr. J. Zool. 108:21-36.

Shmida, A. 1985. Biogeography of the desert flora. p. 23-77. In: M. Evenari, I. Noy-Meir, and D.W. Goodall (eds). Ecosystems of the world. vol. 12A Elsevier, Amsterdam.

Strohbach, B.J. 1992. Loss of genetic diversity due to veld degradation-a case study in the northern Kalahari, Grootfontein district. Dinteria 23:102-115.

Sullivan, S. 1996. Towards a non-equilibrium ecology: perspectives from an arid land. J. Biogeog. 23:1-5.

Thomson, J.D., G. Weiblem, B.A. Thomson, S. Alfaro and $P$. Legendre. 1996. Untangling multiple factors in spatial distributions: lilies, gophers, and rocks. Ecol. 77:1698-1715.

Van der Merwe, J.H. 1983. National atlas of South West Africa (Namibia). National Book Printers, Cape Town, So. Africa.

Walter, H. 1939. Grassland, Savanne und Busch der ariden Teile Afrikas in ihrer ökologischen Bedingtheit. Jaarb. wissensch. Bot. 87:750-860.
Ward, D. 1996. Game and stock farming in arid Namibia. Namib Bull. 13:8-9.

Ward, D., D. Saltz and L. Olsvig-Whittaker. 1999. Distinguishing signal from noise: longterm studies of vegetation in Makhtesh Ramon erosion cirque, Negev desert, Israel. Plant Ecol. In Press.

Ward, D., B.T. Ngairorue, J. Kathena, R. Samuels, and Y. Ofran. 1998. Land degradation is not a necessary outcome of communal pastoralism in arid Namibia. J. Arid Environs. 40:357-371.

Ward, D. and I. Kapofi. 1999. Long-term declines in grassland productivity in arid Otjimbingwe, Namibia. In prep.

Wiegand, T. and S.J. Milton. 1996 Vegetation change in semiarid communities: Simulating probabilities and time scales. Vegetatio 125:169-183.

Whittaker, R.H. and P.L. Marks. 1975. Methods of assessing terrestrial productivity. p. 55-118. In: H. Lieth and R.H. Whittaker (eds). Primary productivity of the biosphere. Springer Verlag, New York. 


\title{
Ungulate herbivory on Utah aspen: Assessment of long- term exclosures
}

\author{
CHARLES E. KAY AND DALE L. BARTOS
}

Authors are Natural Resource Policy Associate, Institute of Political Economy and Adjunct Assistant Professor, Department of Political Science, Utah State University, Logan, Utah 84322; and Ecologist, USDA Forest Service, Rocky Mountain Research Station, Logan, Utah 84321.

Abstract

The role of livestock grazing and big-game browsing in the decline of aspen (Populus tremuloides Michx.) in the Intermountain West has long been questioned.All known aspen exclosures $(n=8)$ on the Dixie and Fishlake National Forests in south-central Utah were measured during late summer of 1995 and 1996 to determine aspen stem dynamics, successional status, and understory species composition. Five of the exclosures were of a 3-part design with a total-exclusion portion, a livestockexclusion portion, and a combined-use portion which permitted the effects of deer (Odocoileus hemionus) and elk (Cervus elaphus) herbivory to be measured separately from those of livestock. Aspen within all total-exclusion plots successfully regenerated and developed multi-aged stems without the influence of fire or other disturbance. Aspen subjected to browsing by wildlife, primarily mule deer, either failed to regenerate successfully or regenerated at stem densities significantly lower $(2,498$ stems ha-1) than that on total-exclusion plots $\left(4,474\right.$ stems $\left.^{-1} a^{-1}\right)$. On combined wildlife-livestock-use plots, most aspen failed to regenerate successfully, or did so at low stem densities $\left(1,012 \mathrm{stems}^{-h^{-1}}{ }^{-1}\right)$. Aspen successfully regenerated on ungulate-use plots only when deer numbers were low. Similarly, ungulate herbivory had significant effects on understory species composition. In general, utilization by deer tended to reduce shrubs and tall palatable forbs while favoring the growth of native grasses. The addition of livestock grazing, however, tended to reduce native grasses while promoting introduced species and bare soil. Thus, communities dominated by old-age or single-age trees appear to be a product of ungulate browsing, not a biological attribute of aspen as has been commonly assumed. There was no evidence that climatic variation affected aspen regeneration. Observed differences are attributed to varied histories of ungulate herbivory.

Key Words: Populus tremuloides communities, reproduction, decline, cattle grazing, deer browsing, elk browsing, undergrowth.

Aspen (Populus tremuloides Michx.) in the western United States does not commonly grow from seed because of its demanding seed bed requirements (Kay and White 1995,

\footnotetext{
Research was funded by U.S. Forest Service's Intermountain Research Station (now part of the Rocky Mountain Research Station) and we thank the many agency employees who helped with various aspects of this project, especially Robert B. Campbell, Jr. and Dr. Walter F. Mueggler (Scientist Emeritus). Also, Brad Williams and the Utah State Trust Lands Administration for granting access to their files on the Parker Mountain exclosure.

Manuscript accepted 28 June 1999.
}

\section{Resumen}

El papel del apacentamiento del ganado y el ramoneo de la fauna silvestre mayor en la disminución del "Aspen" (Populus tremuloides Mitch.) en la región intermontañosa del oeste has sido ampliamente cuestionado. A fines de los veranos de 1995 y 1996 se midieron todas las exclusiones conocidas $(n=8)$ de "Aspen" en los Bosques Nacionales Dixie y Fishlake situados en la región surcentral de Utah. Las mediciones realizadas en estas exclusiones fueron para determinar la dinámica de tallos, el estado sucesional y la composición de especies herbáceas. Cinco de las exclusiones estuvieron dentro de un diseño de tres factores: exclusión total, exclusión contra el ganado y uso combinado, el cual permitía medir separadamente los efectos de la herbívora de venados (Odocoielus hemonius) y alces (Cervus elaphus) de la del ganado. El "Aspen" se regeneró exitosamente dentro de las exclusiones, y sin la influencia del fuego u otro factor de disturbio, desarrollo una estructura de tallos de diferentes edades. El "aspen" sujeto al ramoneo de la fauna silvestre, principalmente venado, fallo en regenerarse exitosamente o se desarrollo con densidades de tallos significativamente menores $(2,498$ tallos ha' $)$ que el "aspen de las parcelas totalmente excluidas $\left(4,474\right.$ tallos ha $\left.{ }^{-1}\right)$. En las parcelas de uso combinado, ganado-fauna, la mayoría del aspen no se regeneró satisfactoriamente o lo hizo con bajas densidades de tallos (1,012 tallos ha $\left.{ }^{-1}\right)$. El "Aspen" se regeneró exitosamente en las parcelas utilizadas por ungulados solo cuando el número de venados fue bajo. En forma similar, la herbívora de los ungulados tuvo efectos significativos en la composición del estrato herbáceo. En general, la utilización por el venado tendió a reducir los arbustos y las hierbas altas palatables mientras que favoreció el crecimiento de los zacates nativos. Por otra parte, la adición del apacentamiento de ganado domestico, tendió a reducir los zacates nativos y promovió el desarrollo de especies introducidas y de suelo desnudo. Así, las comunidades dominadas por arboles viejos o de una sola edad parecen ser el producto del ramoneo por los ungulados y no un atributo biológico del "Aspen" como comúnmente se ha asumido. No hubo evidencia de que la variación climática afectara la regeneración del "Aspen". Las diferencias observadas se atribuyeron a diferentes historiales de herbívora de los ungulados.

McDonough 1979). Because individual trees are relatively shortlived ( $<150$ years), long-lived aspen clones are often dependent on periodic disturbance such as fire to stimulate vegetative regeneration via root suckering, and to reduce conifer competition (Bartos and Mueggler 1981, Shepperd and Smith 1993).

Aspen has been declining throughout the Intermountain West since shortly after European settlement (Kay 1997a, Bartos and 


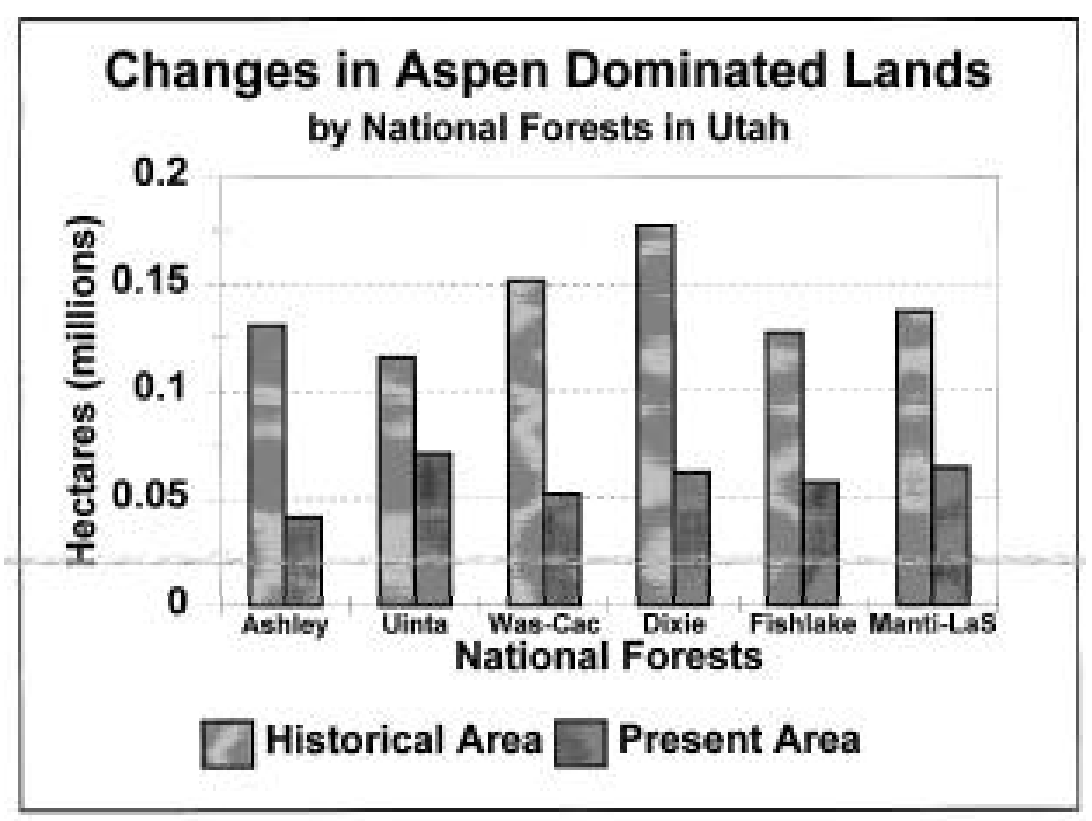

Fig. 1. The decline of aspen on National Forests in Utah. Unpublished forest inventory data, Rocky Mountain Research Station, USDA Forest Service, used with permission.

Campbell 1998). On the Fishlake and Dixie National Forests in Utah, for example, there were historically over 304,000 ha of aspen; today there are only approximately 120,000 ha (Fig. 1). Furthermore, many aspen stands contain old-age or single-age trees and have not successfully regenerated for 80 years or longer (Mueggler 1989).

Several hypotheses have been advanced to explain this decline. These include fire suppression (Houston 1973, Despain et al 1986), climate change (Despain et al. 1986, Romme et al. 1995), livestock grazing (Sampson 1919, Baker 1925), and browsing by mule deer (Odocoileus hemionus) and/or elk (Cervus elaphus) (Olmstead 1979, Shepperd and Fairweather 1994).

To test the ungulate herbivory hypothe- ses, we measured all of the long-term, aspen-containing exclosures on the Fishlake and Dixie National Forests in south-central Utah. These exclosures, established during the 1930s to 1970 s, were built to study the effect of livestock and/or wildlife use on aspen communities (Young 1956, Laycock 1969).

\section{Methods}

Laycock's (1975) list of range reference sites in Utah was first checked for aspencontaining exclosures on the Fishlake and Dixie National Forests. Forest Service employees on both national forests were then contacted to see if these exclosures still existed and if additional aspen-con- taining exclosures were present on the 2 forests. These potential study sites were subsequently field-checked to see if the exclosures were still functional. We tried to locate in agency files all previous vegetation data, written description of permanent vegetation sampling schemes, and any old photographs.

Some of the exclosures were of a 2-part design where an inside area was fenced to exclude livestock, primarily cattle, but deer and elk had access. Adjacent unfenced outside plots were grazed by both wild and domestic ungulates. Other exclosures were of a 3-part design where 1 area was fenced to exclude all ungulates (treatment 1), another was fenced to exclude livestock (treatment 2 ), and outside areas were open to wild and domestic ungulates (treatment 3 ).

At each exclosure, any permanent aspen plots previously established by the agencies were resampled and permanent photopoints rephotographed. Sampling was done during late summer of 1995 and 1996. Next, 2 x 30 m belt transects were placed in representative aspen communities within each of the various parts of each exclosure (Kay 1990). The varied size of exclosures did not always allow sampling with an equal number of transects (Table 1). Each treatment at the following exclosures were sampled by 3 belt transects: Pot Holes, Blind Lake, Riddle Swale, and Hancock. Each treatment on Park Pasture was sampled by 4 transects, and Parker Mountain by 6. At Woodchuck, treatments 1 and 2 were sampled by 3 transects and treatment 3 by 2 ; at Grindstone, treatments 1 and 2 were also sampled by 3 transects, but treatment 3 by 4. To facilitate recording data, each $30 \mathrm{~m}$ transect was subdivided into 3 segments and the number of live aspen stems was recorded using the following size classes within each segment: (1) stems less than 2 $\mathrm{m}$ tall, (2) stems greater than $2 \mathrm{~m}$ tall but

Table 1. Location and description of aspen containing exclosures in south-central Utah, compiled in 1995-1996.

\begin{tabular}{|c|c|c|c|c|c|c|c|c|c|c|}
\hline \multirow{2}{*}{ Exclosure } & \multirow{2}{*}{$\begin{array}{c}\text { Land } \\
\text { Ownership }\end{array}$} & \multicolumn{3}{|c|}{ Location } & \multirow{2}{*}{$\begin{array}{c}\text { Year } \\
\text { established }\end{array}$} & \multicolumn{2}{|c|}{ Size $(m)$} & \multirow[t]{2}{*}{ Elevation } & \multirow{2}{*}{$\begin{array}{l}\text { Main } \\
\text { aspect }\end{array}$} & \multirow{2}{*}{$\begin{array}{c}\text { Vegetation } \\
\text { type }^{2}\end{array}$} \\
\hline & & Township & Range & Section & & $\begin{array}{l}\text { Livestock } \\
\text { exclusion }\end{array}$ & $\begin{array}{l}\text { Total } \\
\text { exclusion }\end{array}$ & & & \\
\hline & & & & & & & & $(\mathrm{m})$ & & \\
\hline Pot Holes & DNF & $30 \mathrm{~S}$ & $3 \mathrm{E}$ & 27 & 1958 & $62 \times 63$ & None & 2743 & NW & $\mathrm{A}, \mathrm{S} / \mathrm{G}$ \\
\hline Park Pasture & DNF & $31 \mathrm{~S}$ & $5 \mathrm{E}$ & 22 & 1957 & $88 \times 94$ & None & 2652 & $\mathrm{NE}$ & $\mathrm{A}, \mathrm{G}$ \\
\hline Blind Lake & DNF & $30 \mathrm{~S}$ & $4 \mathrm{E}$ & 24 & 1958 & $44 \times 117$ & None & 2984 & SE & A,G \\
\hline Riddle Swale & DNF & $33 \mathrm{~S}$ & $1 \mathrm{~W}$ & 19 & 1957 & $65 \times 76$ & $65 \times 113$ & 2554 & $\mathrm{~N}$ & $\mathrm{~A}, \mathrm{~S} / \mathrm{G}, \mathrm{C}$ \\
\hline Woodchuck & DNF & $31 \mathrm{~S}$ & $21 / 2 \mathrm{~W}$ & 33 & 1947 & $63 \times 63$ & $63 \times 63$ & 2804 & $\mathrm{~S}$ & $\mathrm{~A}, \mathrm{~S} / \mathrm{G}$ \\
\hline Grindstone & FNF & $29 \mathrm{~S}$ & $4 \mathrm{~W}$ & 29 & 1934 & $46 \times 63$ & $46 \times 63$ & 2816 & $\mathrm{~S}$ & $\mathrm{~A}, \mathrm{C}$ \\
\hline Hancock & FNF & $26 \mathrm{~S}$ & $1 \mathrm{E}$ & 11 & 1962 & $61 \times 61$ & $61 \times 61$ & 3054 & SE & $\mathrm{A}, \mathrm{C}$ \\
\hline Parker Mountain & UT & $28 \mathrm{~S}$ & $1 \mathrm{~W}$ & 26 & 1974 & $100 \times 100$ & $100 \times 100$ & 2804 & $\mathrm{E}$ & $\mathrm{A}, \mathrm{S} / \mathrm{G}$ \\
\hline
\end{tabular}

${ }^{\mathrm{D}} \mathrm{DNF}$ = Dixie National Forest, FNF = Fishlake National Forest, UT= Utah State School Trust Lands.

${ }^{2}$ Vegetation types within the exclosures. $\mathrm{A}=$ aspen, $\mathrm{S} / \mathrm{G}=$ sagebrush/grasslands, $\mathrm{G}=$ grasslands, and $\mathrm{C}=$ conifers 
less than $5 \mathrm{~cm}$ diameter at breast height (DBH), (3) stems between 6 and $10 \mathrm{~cm}$ DBH, (4) stems between 11 and $20 \mathrm{~cm}$ $\mathrm{DBH}$, and (5) stems greater than $21 \mathrm{~cm}$ DBH. Ages of aspen within each size class were determined by coring the larger and cutting the smaller stems and counting annual rings.

The number and species of conifers were recorded on the $2 \times 30 \mathrm{~m}$ belt transects using the same size classes. While a $2 \times 30 \mathrm{~m}$ belt transect is adequate to measure aspen stem dynamics and conifer seedlings (Bartos et al. 1994), a plot of that size tends to underestimate the more widely spaced conifers. To overcome this problem, the total percent conifer canopy cover was estimated in each aspen stand following Mueggler (1988).

Aspen and conifer stem counts on each of the $2 \times 30 \mathrm{~m}$ belt transects were used to produce a mean number of stems per hectare by size classes for each treatment at each site. The treatment means of the various aspen size class data were then compared using repeated measures analysis of variance. Each site was considered an experimental unit for this analysis.

Frequency and canopy-cover of understory plants, bare soil, and rock were recorded from $0.1 \mathrm{~m}^{2}$ plots at $1 \mathrm{~m}$ intervals to the right of each of the belt-transect's centerline (Daubenmire 1959). Readings from all the $0.1 \mathrm{~m}^{2}$ understory plots were averaged within each treatment and then compared using Student's t-test.

Other information recorded at each study site included: Universal Mercator Grid coordinates, elevation, aspect, old and new bark damage, highlining, and sucker browsing. The last 3 items provided an estimate of past ungulate use. Elk and moose (Alces alces) strip-off and eat the bark of aspen. Such bark damage usually occurs during winter when other foods are in short supply. Mule deer do not strip aspen bark, but mule deer, elk, and moose all browse aspen when the plants are available.

To determine the effects of deer herbivory on Indian paintbrush (Castilleja miniata Dougl.) we measured the height, crown diameter, total number of flower stalks, and the number of grazed flower stalks. These measurements were made just at the Hancock site.

\section{Results}

Many of the aspen-containing exclosures listed by Laycock (1969) for southcentral Utah no longer exist or were not maintained. Thus, only 8 exclosures containing aspen were evaluated (Table 1). Prior data were found for the Grindstone Flat exclosure. Photographs showing the originally enclosed aspen communities were found for 4 exclosures (Pot Holes, Park Pasture, Grindstone Flat, and Parker Mountain).

\section{Pot Holes}

With protection from cattle grazing, the aspen stand successfully established new stems without fire or other disturbance, and increased in size inside the exclosure as evidenced by photographs. The new suckers established in the early 1970s when mule deer numbers were low (Fig. 2). Later when deer numbers expanded the animals consumed all the lower branches from the newly grown aspen, termed highlining, and prevented new suckers from exceeding $1 \mathrm{~m}$ in height. The aspen stand inside the exclosure is now composed of

Table 2. Mean aspen stem densities by size classes and estimated conifer canopy cover inside and outside exclosures in south-central Utah in 1995-96.

\begin{tabular}{|c|c|c|c|c|c|c|}
\hline \multirow[b]{2}{*}{ Exclosure } & \multicolumn{4}{|c|}{ Mean aspen stem density by size classes } & & \multirow{2}{*}{$\begin{array}{c}\text { Conifer } \\
\text { canopy } \\
\text { cover }\end{array}$} \\
\hline & $<2 \mathrm{~m}$ tall & $\begin{array}{l}2 \mathrm{~m} \text { tall to } \\
5 \mathrm{~cm} \mathrm{DBH}\end{array}$ & $\begin{array}{l}6 \text { to } 10 \mathrm{~cm} \\
\text { DBH }\end{array}$ & $\begin{array}{l}11 \text { to } 20 \mathrm{~cm} \\
\text { DBH }\end{array}$ & $\begin{array}{l}>20 \mathrm{~cm} \\
\mathrm{DBH}\end{array}$ & \\
\hline & \multicolumn{5}{|c|}{ 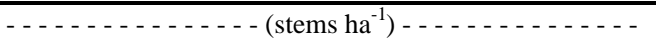 } & $(\%)$ \\
\hline \multicolumn{7}{|c|}{$\mathrm{s}^{2}$} \\
\hline Livestock exclusion & 7,348 & 3,791 & 2,221 & 618 & 333 & $<1$ \\
\hline Outside & 9,018 & 668 & 0 & 55 & 55 & $<1$ \\
\hline \multicolumn{7}{|l|}{ Park Pasture } \\
\hline Livestock exclusion & 1,221 & 4,676 & 3,758 & 1,378 & 250 & $<1$ \\
\hline Outside & 459 & 835 & 835 & 0 & 584 & $<1$ \\
\hline \multicolumn{7}{|l|}{ Blind Lake } \\
\hline Livestock exclusion & 9,574 & 8,684 & 3,228 & 1,057 & 556 & $<1$ \\
\hline Outside & 8,963 & 6,568 & 167 & 55 & 668 & $<1$ \\
\hline \multicolumn{7}{|l|}{ Riddle Swale } \\
\hline Total exclusion & 7,228 & 4,670 & 2,780 & 1,890 & 168 & $<1$ \\
\hline Livestock exclusion & 8,613 & 2,446 & 834 & 0 & 449 & $<1$ \\
\hline Outside & 1,890 & 0 & 111 & 0 & 222 & 5 \\
\hline \multicolumn{7}{|l|}{ Woodchuck } \\
\hline Total exclusion & 5,177 & 4,787 & 2,394 & 1,169 & 390 & None \\
\hline Livestock exclusion & 946 & 0 & 56 & 779 & 390 & None \\
\hline Outside & 2,088 & 0 & 0 & 1,086 & 0 & None \\
\hline \multicolumn{7}{|l|}{ Grindstone Flat } \\
\hline Total exclusion & $\mathrm{NA}^{1}$ & 2,505 & 3,396 & 1,614 & 333 & 30 \\
\hline Livestock exclusion & NA & 0 & 222 & 835 & 668 & 50 \\
\hline Outside & NA & 0 & 0 & 167 & 752 & 60 \\
\hline \multicolumn{7}{|l|}{ Hancock } \\
\hline Total exclusion & 5,288 & 7,738 & 1,225 & 557 & 445 & 11 \\
\hline Livestock exclusion & 2,728 & 0 & 0 & 0 & 557 & 31 \\
\hline Outside & 4,676 & 0 & 0 & 0 & 500 & 30 \\
\hline \multicolumn{7}{|l|}{ Parker Mountain } \\
\hline Total exclusion & 974 & 2,672 & 1,308 & 84 & 500 & None \\
\hline Livestock exclusion & 4,509 & 389 & 0 & 0 & 84 & None \\
\hline Outside & 1,030 & 28 & 0 & 0 & 306 & None \\
\hline \multicolumn{7}{|l|}{ Means } \\
\hline Total Exclusion & $4,668 \mathrm{a}^{2}$ & $4,474 \mathrm{a}$ & $2,221 \mathrm{a}$ & $1,063 \mathrm{a}$ & $734 a$ & - \\
\hline Livestock Exclusion & 4,991a & $2,498 b$ & $1,289 \mathrm{ab}$ & $583 a$ & $822 a$ & - \\
\hline Outside & $4,018 \mathrm{a}$ & $1,012 b$ & $139 b$ & $170 \mathrm{a}$ & $772 \mathrm{a}$ & - \\
\hline
\end{tabular}

NA $=$ Stems less than $2 \mathrm{~m}$ tall were not counted because most had been consumed by a recent fire - see text.

${ }^{2}$ Means within columns followed by the same letter are not different at $\mathrm{P}<0.08$ by analysis of variance on means. 
stock had been excluded, while Antennaria microphylla Rydb. was more prevalent outside the exclosure. There was also more bare soil and less litter outside the exclosure than inside.

\section{Park Pasture}

When the Park Pasture exclosure was erected on the east side of Boulder Mountain, the area was a heavily used sheep-cattle allotment. Sheep were eliminated in 1963 and cattle herbivory subsequently reduced (U.S. Forest Service 1995). Historically, the area was also grazed by high numbers of mule deer, but that herd has since declined (Fig. 2). When the exclosure was built elk were rare, but they are now common. In fact, several fresh elk beds were observed inside the exclosure when the site was visited during August 1995.

There were no young aspen stems in 1957, but with exclusion of livestock, aspen regenerated and spread inside the exclosure (Fig. 3). This exclosure is also on an aspen-grassland ecotone with few conifers. Ponderosa pine, Douglas-fir, spruce (Picea spp. A. Dietr.), and subalpine fir (Abies lasiocarpa (Hook.) Nutt.) are the most common species in the immediate area. The largest aspen were 38-40 cm DBH and were $105-115$ years old. Inside the exclosure there were numerous $10-15 \mathrm{~cm}$ DBH stems that were 25-30 years old, but there were none outside (Table 2). These began growth during the mid-1960's when combined high deer and cattle grazing apparently prevented aspen regeneration outside the exclosure. When deer numbers declined during the early to mid-1970s (Fig. 2), aspen regenerated both inside and outside the exclosure, but trees were about 5-times more numerous where cattle also were excluded (Table 2). The 6-10 cm DBH stems were all approximately 20 years old. Rebounding deer populations during the 1980s highlined the regenerated aspen and prevented new suckers from growing taller. Little difference, however, existed in understory species composition or frequency.

\section{Blind Lake}

The Blind Lake exclosure on the north side of Boulder Mountain is in an area comprised primarily of aspen and small meadows. Aspen stems inside the exclosure are multi-sized and multi-aged, and began regenerating shortly after the exclosure was erected (Table 2). The elimination of cattle grazing reduced browsing on the aspen suckers and allowed them to grow into the larger size classes. Aspen

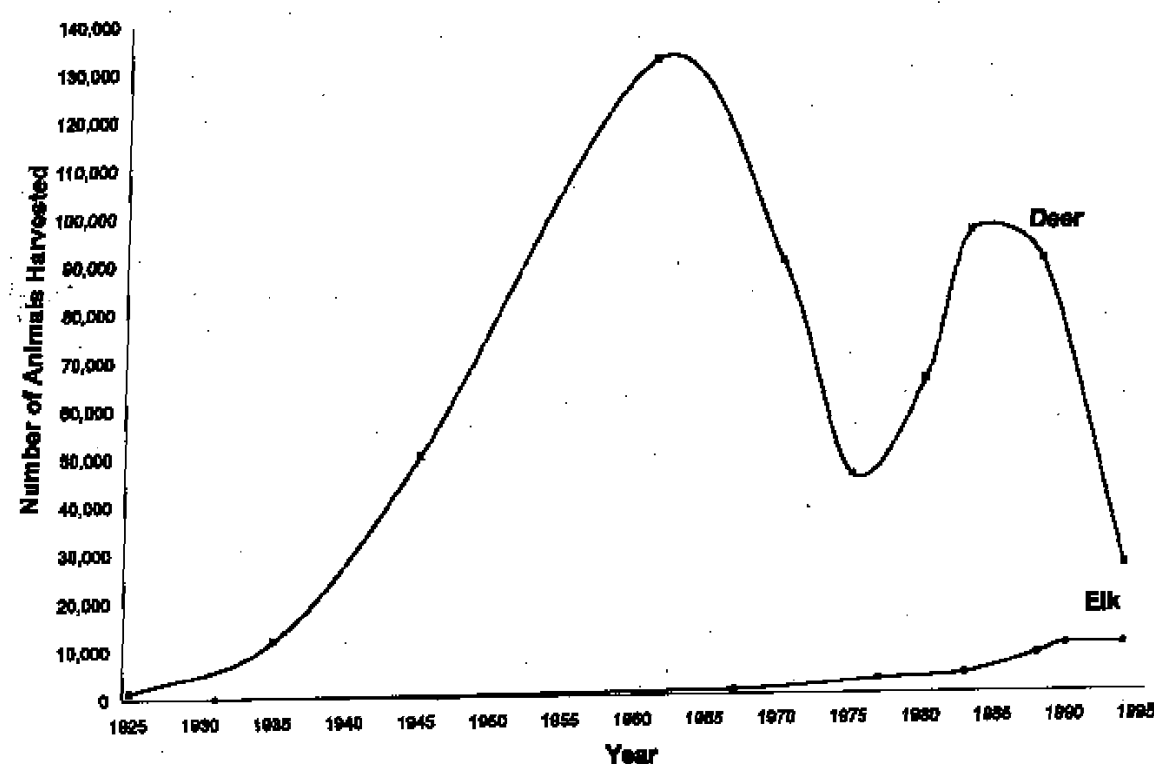

Fig. 2. The number of deer and elk harvested by hunters in Utah from 1925 to 1995. (Utah Div. of Wildlife Resources' Annual big Game Reports-data smoothed to show historical trends.)

outside the exclosure regenerated approximately 20 years ago when deer populations plummeted (Fig. 2), despite continued access by cattle. The largest aspen were $30-38 \mathrm{~cm} \mathrm{DBH}$ and $95-105$ years old, while the $4-5 \mathrm{~cm}$ DBH stems were 18-25 years of age. Photographic evidence indicates that the aspen clone inside the exclosure has increased in area displacing a largely grassland community.

There was significantly less snowberry (Symphoricarpos oreophilus Gray) $(\mathrm{P}<0.01)$ and lovage (Ligusticum porteri Coult. \& Rose) $(\mathrm{P}<0.01)$, and significantly more bare soil $(\mathrm{P}<0.01)$ and dandelion (Taraxacum officinale Weber ex Wiggers) outside the exclosure. In general, there were more palatable forbs (U.S. Forest Service 1937, Nelson and Leege 1982, Wallmo and Regelin 1981) inside than outside the exclosure, while less palatable and non-native forbs were more common outside than inside. There was also more vegetative cover inside than outside the exclosure $(\mathrm{P}<0.01)$.

\section{Riddle Swale}

Riddle Swale is a 3-part exclosure with a total-exclusion portion, a livestockexclusion portion, and an outside plot open to both wildlife and cattle. The site is located on the west side of Escalante Mountain at the ecotone between aspen, sagebrush, and pinyon-juniper. A few Utah juniper (Juniperus osteosperma (Torr.) Little), pinyon pine (Pinus mono phylla Torr. \& Frem. In Frem.), ponderosa pine, and Douglas-fir are found both inside and outside the exclosure.
Inside the total-exclusion part aspen began regenerating shortly after the exclosure was constructed in 1957; the stems are now multi-sized and multi-aged (Table 2 ). In the livestock-exclusion portion of the exclosure, aspen only regenerated when deer numbers declined around 20 years ago (Fig.2). As the deer recovered, however, they highlined all the previous aspen regeneration inside the livestock exclosure and prevented any new aspen suckers from growing more than $1 \mathrm{~m}$ tall. Where both cattle and deer grazed, few aspen stems attained more than $2 \mathrm{~m}$ in height (Table 2). The largest aspen at this site were $23-26 \mathrm{~cm} \mathrm{DBH}$ and $72-78$ years old. The $8-10 \mathrm{~cm}$ DBH stems were $20-25$ years old, and the $3-5 \mathrm{~cm}$ stems were 14-20 years old.

There were also major differences in understory species composition. Deer use only and combined use eliminated Indian paintbrush, while combined big game and cattle use significantly $(\mathrm{P}<0.01)$ reduced the canopy cover of native grasses compared to the exclosures. Conversely, sagebrush increased under deer use, but more so under combined use. Bare soil and rock were not apparent where ungulate herbivory was absent, but increased to $6.4 \%$ cover where only wildlife grazed and to $27.2 \%$ cover with combined deer-cattle use $(\mathrm{P}<0.01)$.

\section{Woodchuck}

Woodchuck is a 3-way exclosure built on the northeast slope of Mount Dutton. Although this exclosure is at over $2,800 \mathrm{~m}$ 

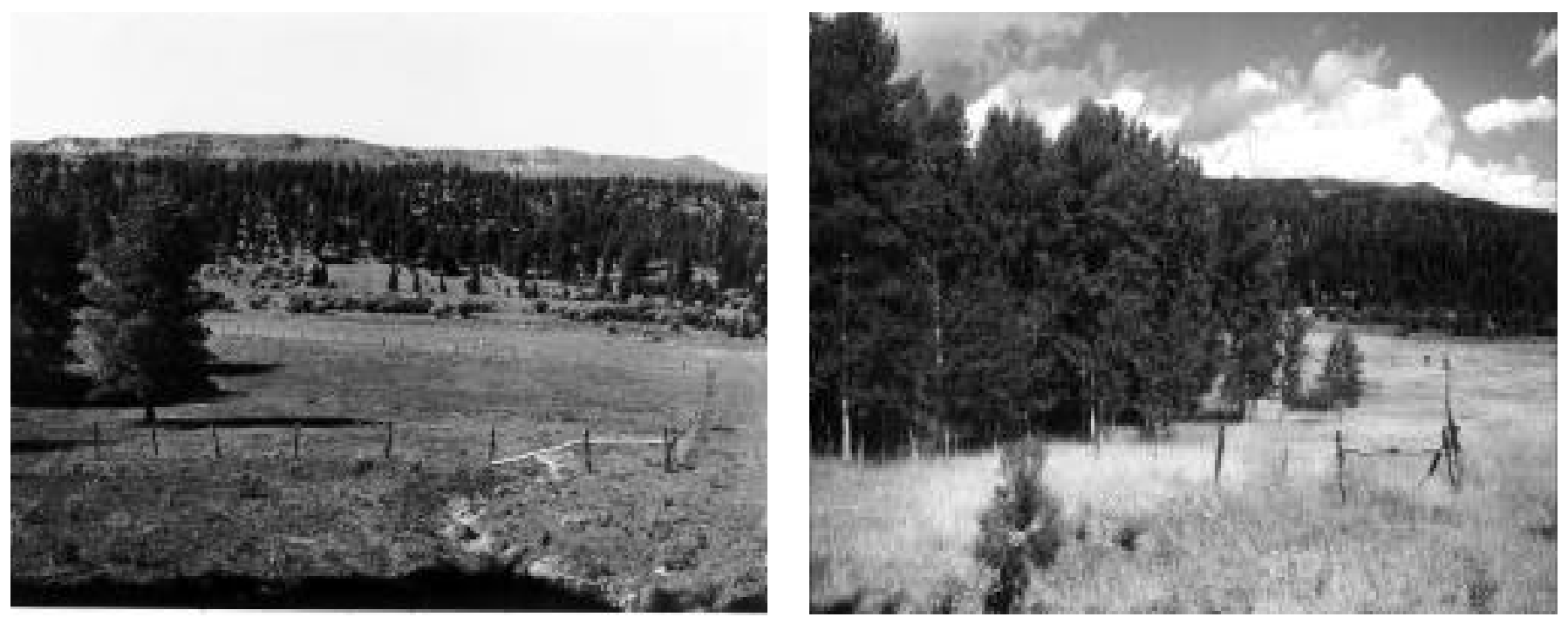

Fig. 3. Photographs of the Park Pasture exclosure: (a) taken in September 1958 shortly after the exclosure was constructed and showing no aspen regeneration; and (b) in August 1995 showing spread of aspen inside the exclosure.

in elevation, it is surrounded by extensive sagebrush-grasslands and lacks conifers. Cattle have used this allotment historically, and deer numbers have also been high. Elk have recently become common on Mount Dutton but do not appear to use this isolated patch of aspen.

Aspen within the total-exclusion part is multi-sized and multi-aged (Table 2), and began regenerating shortly after the exclosure was constructed in 1947. No new aspen stems have attained heights of $2 \mathrm{~m}$ or more in the livestock-exclusion or combined-use areas. The deer at this site have not allowed aspen to regenerate even where cattle have been excluded. The largest aspen were 25-30 cm DBH and 100+ years old, while aspen in the $15-16 \mathrm{~cm}$ size class were 65-70 years of age. Apparently, some event in the late 1920 s and early 1930 s allowed some aspen regeneration in this stand before it was enclosed.

Deer use significantly reduced wild rose (Rosa woodsii Lindl.), snowberry, lupine (Lupinus caudatus Kellogg), and Indian paintbrush, but favored the growth of native grasses, especially needle and thread (all $\mathrm{P}<0.01$ ). The addition of cattle grazing significantly reduced native grass cover $(<0.01)$ and significantly increased the amount of bare soil $(\mathrm{P}<0.01)$. The canopy cover of introduced Kentucky bluegrass (Poa pratensis L.) increased from $1.9 \%$ in the total exclusion area, to $23.7 \%$ under deer only use $(\mathrm{P}<0.01)$, and to $50.9 \%$ with the addition of cattle grazing $(\mathrm{P}<0.01)$. Total vegetative understory cover declined significantly $(\mathrm{P}<0.01)$ from $95.9 \%$ in the non-grazed area to $77.7 \%$ in the wildlife only area to $63.7 \%$ with combined use.

\section{Grindstone Flat}

The 3-part exclosure at Grindstone Flat (Table 1) was evaluated during the 1950s (Young 1956), and then remeasured by the U.S. Forest Service in 1975 (Mueggler and Bartos 1977). Part of the site was originally clear-cut prior to exclosure construction, but $1 / 3$ of each exclosure, as well as all of the outside aspen, were left uncut. Only the uncut areas were analyzed to maintain comparability with the other sites.

Aspen regenerated inside the totalexclusion area, while deer use prevented aspen regrowth in the livestock-exclusion area, as well as the outside area (Table 2). Spruce and subalpine fir have heavily invaded the area (Mueggler and Bartos 1977)

During late June 1996 the exclosure and much of the surrounding lands were burned by the Pole Creek wildfire. Much of the vegetation inside the exclosure complex was burned, and the old exclosure pole-fence destroyed. The total-exclusion and livestock-exclusion areas were completely consumed by flames, as was the surrounding outside aspen. In contrast, the cut total-exclusion area was largely unburned while the cut livestock-exclusion area did not burn at all.

Since this is 1 of only 2 long-term exclosures on the Fishlake National Forest containing aspen, the Forest Service rebuilt the exclosure fences in 1997 . We were able to measure aspen stem densities in September 1996 because the largersized live stems were too green to be consumed by the fire. Aspen stems less than 2 $\mathrm{m}$ tall, however, were not quantified because many of those were removed by the fire. Understory species composition was not measured for the same reason.

Of most relevance in this exclosure comparison is that aspen in the totalexclusion area successfully regenerated and produced a multi-aged stand prior to the 1996 fire, while aspen in the livestock exclosure and outside combined use areas produced no new stems greater than $2 \mathrm{~m}$ tall. Conifer cover in the total-exclusion area was less than in the areas accessible to either deer or cattle (Table 2).

The largest aspen trees were $38-44 \mathrm{~cm}$ DBH, but age determination was difficult because of extensive heart rot. In 1975 , Mueggler and Bartos (1977) recorded a 41 cm DBH aspen that was 175 years old, so the few remaining, unburned trees were likely approaching or near the maximum age (200 years) recorded for aspen in the Intermountain West (Jones and Schier 1985).

\section{Hancock}

This 3-part exclosure is located above Doctor Canyon, approximately $3 \mathrm{~km}$ southeast of Hancock Flat and $1 \mathrm{~km}$ northeast of Rust Spring. Unlike the other exclosures in this study, Hancock has been a sheep allotment and mule deer were the most abundant wild ungulate.

Aspen in the total-exclusion portion began regenerating shortly after the exclosure was constructed and today is multisized and multi-aged despite invasion by conifers (Table 2). Aspen has not regenerated successfully in either the wildlifeonly or the combined-use areas; all of the aspen suckers that occur have been repeatedly browsed by deer and/or sheep. When this site was measured in July, mule deer 
had already browsed many of the new aspen suckers in the livestock-exclusion portion of the exclosure. The largest aspen stems were $30 \mathrm{~cm} \mathrm{DBH}$ and $105+$ years old. Spruce canopy cover appeared greater on the grazed portion than on the ungrazed portion of the exclosure.

Deer grazing and combined use created major differences in understory species composition. Both deer grazing and combined use significantly $(\mathrm{P}<0.01)$ reduced Indian paintbrush, dandelion, and total vegetative cover, and significantly $(\mathrm{P}<0.01)$ increased cover of grass, yarrow (Achillea millefolium L.), rock, bare soil, and litter. Deer grazing also significantly $(\mathrm{P}<0.01)$ reduced height, crown diameter, and number of flower stalks of individual Indian paintbrush plants. Deer had already grazed $63 \%$ of the Indian paintbrush flower stalks inside the livestock-exclusion portion of this exclosure when it was sampled in July.

\section{Parker Mountain}

When this site was fenced (1974) there was concern that browsing by jackrabbits (Lepus spp.) might effect aspen regeneration. To monitor this, each of the totalexclusion and livestock-exclusion areas were partitioned with additional fencing to prevent entry by lagomorphs on half of these areas.

The exclosure is on a joint cattle-sheep allotment where mule deer and antelope (Antilocapra americana) have been abundant. In recent years, however, the deer population has declined and most of the present wildlife use is by elk. The exclosures are also near the lower elevation of aspen and the site is surrounded by sagebrush-grasslands.

Exclusion of lagomorphs had no effect on aspen regeneration or understory composition so the 2 data sets were pooled. When protected from ungulates, aspen successfully regenerated on this site producing a multi-aged stand (Table 2). Aspen successfully regenerated in the livestock-exclusion part and on outside plots, especially after deer declined, but at significantly lower $(\mathrm{P}<0.05)$ densities than on the total exclusion plot. The increasing elk population, however, highlined those stems and inflicted extensive bark damage (Krebill 1972) on the unprotected aspen. The largest aspen were 26-28 cm DBH and 90-95 years of age. Photographic evidence indicates that aspen in the totalexclusion part of this exclosure has spread into sagebrush-grasslands, an indication that climate had not limited expansion at this site.
Although this exclosure had been in place for only 22 years, there were significant $(\mathrm{P}<0.05)$ differences in understory species composition. Indian paintbrush and littleflower penstemon (Penstemon pro cerus Dougl. ex Graham) had greater frequency and canopy cover in the totalexclusion area than on the wildlife exclusion area, and they were virtually eliminated by combined wildlife-livestock use. Conversely, native grasses were most abundant in the total-exclusion part (54\%), were halved by wildlife-only use, and reduced to only $16 \%$ under combined use. The addition of livestock grazing also increased $(\mathrm{P}<0.05)$ the amount of bare soil.

\section{Discussion}

\section{Aspen Stem Dynamics}

Aspen within all total-exclusion exclosures regenerated successfully without disturbance and developed multi-sized, multiaged stems, even where the stand had been heavily invaded by conifers (i.e., the Hancock exclosure). Aspen subjected to browsing only by wildlife, primarily mule deer, either failed to produce new stems greater than $2 \mathrm{~m}$ tall, or regenerated at stem densities lower than on the totalexclusion plots. On combined wildlifelivestock use plots, most aspen failed to regenerate successfully, or did so at stem densities lower than on the livestockexclusion plots. Aspen regenerated successfully on livestock-exclosed and combined-use plots only when mule deer pop- ulations were low.

Mule deer have been the most prevalent wild herbivore in south-central Utah since at least the 1930s. Moose were only recently transplanted into the area, and elk populations were very low until the 1980s. Deer numbers in Utah generally peaked during the early 1960s, but declined precipitously by 1975 (Fig. 2). This reduced the browsing pressure on aspen suckers, and many stands in southern Utah were able to regenerate successfully if livestock use was not excessive. An increase in deer during the 1980s prevented new aspen suckers from increasing in height, and the deer also consumed the lower branches from aspen that had regenerated earlier (Fig. 4). In the mid-1990s, mule deer populations again declined, but few aspen stands were able to regenerate successfully because increasing numbers of elk were foraging on the young suckers (Fig. 2). Thus, in some areas of Utah, deer browsing has been replaced by elk browsing. Elk also seem to have a greater preference for aspen than mule deer (Kay 1997b, Shepperd and Fairweather 1994). Episodes of aspen regeneration have been observed in other areas when mule deer (Julander and Low 1976, Olmstead 1979) or elk (Olmstead 1979, Kay and White 1995) numbers were low.

\section{Understory Species Composition}

Understory species composition of aspen stands was significantly affected by ungulate herbivory. In general, utilization by mule deer tended to eliminate palatable

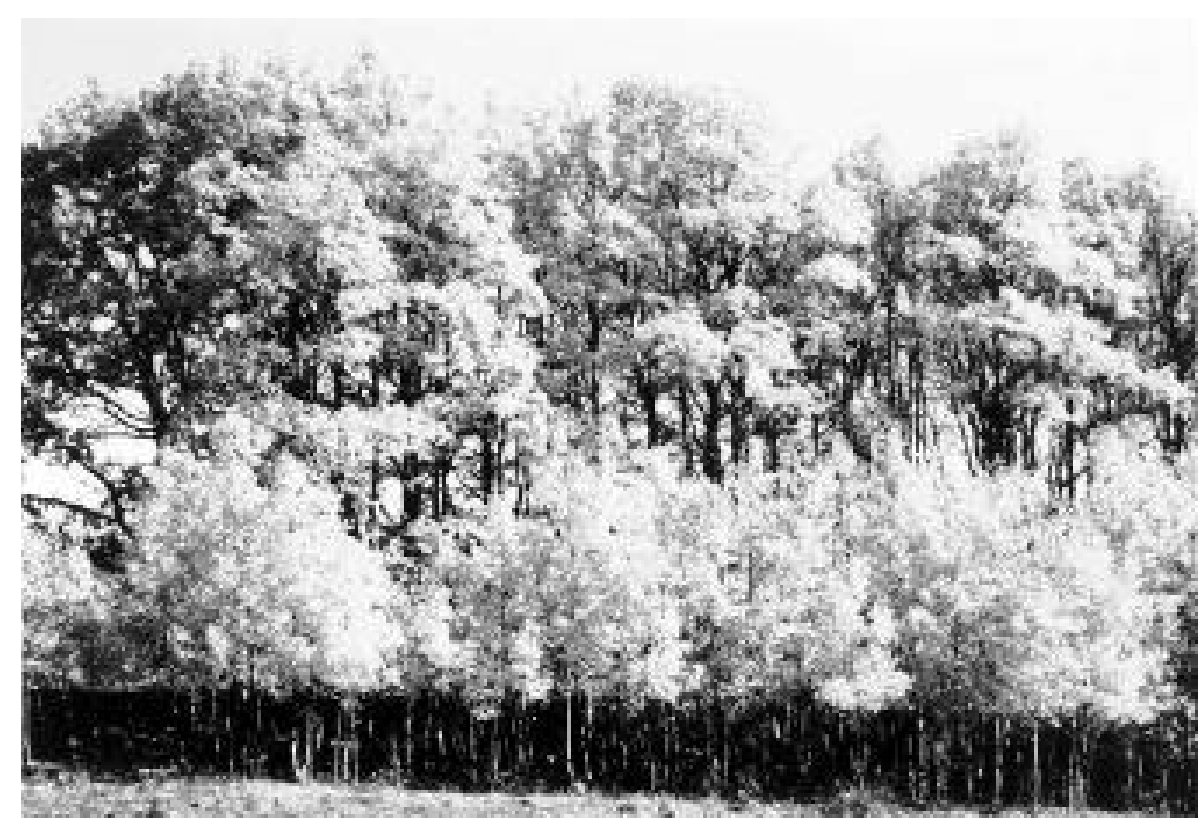

Fig. 4. Highlining by mule deer in a 2-age class aspen stand on the Dixie National Forest. 
Table 3. Mean frequency (Freq.) and canopy cover (C.C.) of undergrowth species on total-exclusion (wild \& domestic ungulates), partial exclusion (livestock), and no-exclusion plots. (Means are based on only those sites where the species occurred; "n" = number of sites where species occurred; summation of cover values therefore are meaningless.)

\begin{tabular}{|c|c|c|c|c|c|c|c|c|c|}
\hline & \multicolumn{3}{|c|}{ TOTAL EXCLUSION } & \multicolumn{3}{|c|}{ PARTIAL EXCLUSION } & \multicolumn{3}{|c|}{ NO EXCLUSION } \\
\hline & $\mathrm{n}$ & Freq. & C.C. & $\mathrm{n}$ & Freq. & C.C. & $\mathrm{n}$ & Freq. & C.C. \\
\hline & \multicolumn{3}{|c|}{$-\cdots(\%)-\cdots$} & \multicolumn{3}{|c|}{$-\ldots-\ldots(\%)-\ldots$} & \multicolumn{3}{|c|}{$-\cdots(\%)-\cdots$} \\
\hline TREES & & & & & & & & & \\
\hline Picea engelmannii Parry ex Engelm. & 1 & 18 & 10.6 & 2 & 45 & 30.3 & 2 & 23 & 14.8 \\
\hline \multicolumn{10}{|l|}{ SHRUBS } \\
\hline Artemisia tridentata Nutt. & 3 & 20 & 7.7 & 4 & 24 & 12.2 & 4 & 25 & 11.3 \\
\hline Artemisia tripartita $\mathrm{Rydb}$ & 1 & 3 & 0.4 & 2 & 2 & 0.2 & 2 & 15 & 4.5 \\
\hline Chrysothamnus nauseosus (Pallas) Britt. & 1 & 1 & 0.1 & 2 & 4 & 1.1 & 2 & 8 & 2.1 \\
\hline Chrysothamnus viscidiflorus (Hook.) Nutt. & 1 & 0 & 0.0 & 2 & 15 & 4.8 & 2 & 20 & 8.1 \\
\hline Juniperus communis L. & 0 & 0 & 0 & 1 & 0 & 0.0 & 1 & 1 & 0.4 \\
\hline Juniperus osteosperma (Torr.) Little & 1 & 7 & 3.3 & 1 & 0 & 0.0 & 1 & 8 & 5.9 \\
\hline Potentilla fruticosa $\mathrm{L}$. & 0 & 0 & 0 & 1 & 4 & 0.3 & 1 & 5 & 0.7 \\
\hline Purshia tridentata (Pursh) DC. & 1 & 0 & 0.0 & 1 & 0 & 0.0 & 1 & 2 & 1.9 \\
\hline Ribes spp. L. & 0 & 0 & 0 & 1 & 8 & 2.9 & 1 & 4 & 1.4 \\
\hline Rosa woodsii Lindl. & 3 & 2 & 0.9 & 4 & 3 & 0.8 & 4 & 4 & 0.8 \\
\hline Symphoricarpos oreophilus Gray & 3 & 17 & 8.0 & 5 & 19 & 8.4 & 5 & 11 & 3.3 \\
\hline \multicolumn{10}{|l|}{ GRAMINOIDS } \\
\hline Agropyron caninum (L.) Beauv. & 3 & 28 & 4.0 & 3 & 16 & 2.4 & 3 & 8 & 0.7 \\
\hline Bromus ciliatus L. & 4 & 28 & 5.6 & 6 & 15 & 1.7 & 6 & 10 & 1.0 \\
\hline Carex spp. L. & 2 & 18 & 0.1 & 1 & 17 & 4.2 & 1 & 0 & 0.0 \\
\hline Festuca idahoensis Elmer & 2 & 1 & 0.1 & 3 & 42 & 9.7 & 3 & 39 & 6.5 \\
\hline Festuca thurberi Vasey & 2 & 40 & 13.4 & 4 & 23 & 5.2 & 4 & 31 & 6.2 \\
\hline Koeleria cristata (L.) Pers. & 1 & 4 & 0.5 & 1 & 35 & 4.2 & 1 & 24 & 2.6 \\
\hline Muhlenbergia wrightii Vasey ex Coult. & 0 & 0 & 0 & 2 & 1 & 0.1 & 2 & 16 & 3.4 \\
\hline Poa interior (NY) & 1 & 7 & 1.1 & 1 & 0 & 0.0 & 1 & 8 & 0.8 \\
\hline Poa pratensis L. & 2 & 8 & 2.8 & 4 & 22 & 15.4 & 4 & 42 & 18.8 \\
\hline Sitanion hystrix (Nutt.) J. G. Sm. & 3 & 18 & 2.6 & 5 & 19 & 3.0 & 5 & 18 & 2.5 \\
\hline Stipa columbiana Macoun & 1 & 4 & 1.8 & 1 & 0 & 0.0 & 1 & 0 & 0.0 \\
\hline Stipa comata Trin. \& Rupr. & 3 & 42 & 11.7 & 6 & 46 & 14.1 & 6 & 30 & 4.1 \\
\hline Stipa lettermanii Vasey & 1 & 17 & 2.3 & 1 & 11 & 2.2 & 1 & 0 & 0.0 \\
\hline \multicolumn{10}{|l|}{ FORBS } \\
\hline Achillea millefolium $\mathrm{L}$. & 2 & 10 & 0.8 & 3 & 34 & 2.7 & 3 & 25 & 14.6 \\
\hline Antennaria microphylla $\mathrm{Rydb}$. & 0 & 0 & 0 & 1 & 0 & 0 & 1 & 54 & 11.9 \\
\hline Aquilegia coerulea James & 1 & 8 & 2.3 & 1 & 3 & 0.2 & 1 & 0 & 0 \\
\hline Aster spp. L. & 1 & 13 & 2.4 & 1 & 9 & 0.9 & 1 & 9 & 0.7 \\
\hline Castilleja linariaefolia Benth. & 3 & 28 & 3.9 & 4 & 6 & 1.1 & 4 & 1 & 0.1 \\
\hline Castilleja miniata Dougl. ex Hook. & 1 & 56 & 29.5 & 1 & 6 & 0.4 & 1 & 2 & 0.2 \\
\hline Fragaria virginiana Duchesne & 0 & 0 & 0 & 1 & 16 & 1.2 & 1 & 3 & 0.2 \\
\hline Galium spp. L. & 1 & 38 & 3.9 & 1 & 28 & 3.6 & 1 & 0 & 0.0 \\
\hline Ligusticum porteri Coult. \& Rose & 0 & 0 & 0 & 2 & 42 & 12.3 & 1 & 0 & 0.0 \\
\hline Lupinus argenteus Pursh & 1 & 37 & 14.2 & 2 & 6 & 1.5 & 2 & 29 & 6.7 \\
\hline Lupinus caudatus Kellogg & 1 & 82 & 40.4 & 1 & 0 & 0.0 & 2 & 18 & 4.4 \\
\hline Penstemon procerus Dougl. ex Graham & 1 & 18 & 3.7 & 1 & 0 & 0.0 & 1 & 0 & 0.0 \\
\hline Phlox spp. L. & 1 & 0 & 0.0 & 1 & 22 & 4.3 & 1 & 6 & 1.2 \\
\hline Potentilla glandulosa Lindl. & 1 & 40 & 8.0 & 1 & 45 & 5.5 & 1 & 10 & 1.0 \\
\hline Potentilla gracilis Dougl. ex Hook. & 0 & 0 & 0 & 1 & 2 & 1.3 & 1 & 0 & 0.0 \\
\hline Senecio spp. L. & 1 & 10 & 2.0 & 1 & 0 & 0 & 1 & 0 & 0 \\
\hline Taraxacum officinale Weber ex Wiggers & 1 & 29 & 4.6 & 3 & 14 & 2.6 & 3 & 31 & 8.7 \\
\hline Vicia americana Muhl. & 0 & 0 & 0 & 1 & 83 & 25.2 & 1 & 72 & 26.5 \\
\hline ROCK & 4 & 1 & 0.3 & 7 & 8 & 3.1 & 7 & 9 & 3.1 \\
\hline BARE SOIL & 4 & 3 & 0.6 & 7 & 13 & 2.0 & 7 & 30 & 9.4 \\
\hline LITTER & 4 & 63 & 25.3 & 7 & 66 & 26.8 & 7 & 69 & 28.9 \\
\hline
\end{tabular}

tall forbs and shrubs while favoring the growth of native grasses and unpalatable forbs (U.S. Forest Service 1937, Nelson and Leege 1982, Wallmo and Regelin 1981) (Table 3). Indian paintbrush in particular was harmed by mule deer herbivory. The addition of livestock, primarily cattle, significantly reduced the native grass cover at most sites, while introduced grasses and bare soil increased. It is clear that the combined level of ungulate use at all sites has not only altered the age structure of aspen stands but also altered understory species composition. It is equally clear that wildlife can dramatically affect the structure of aspen communities. Earlier open-range grazing studies have reported similar findings (Baker 1925, Weatherill and Keith 1969, Julander and Low 1976, Mueggler 1988, Smith et al. 1972).
Numerous hummingbirds were observed feeding on Indian paintbrush inside the total-exclusion area at the Hancock exclosure, but not inside the livestock-exclusion area or on outside plots. Thus, grazinginduced reduction of this flowering forb alone may have major effects on species not normally considered in range-wildlife studies. 


\section{Other Aspen Exclosure Studies}

Aspen exclosure studies throughout the western United States and Canada depict similar findings. Coles (1965) and Mueggler and Bartos (1977) report similar results in central Utah. Kay (1990) measured 14 aspen exclosures in the Yellowstone Ecosystem where elk are the major herbivore. He found that all protected stands regenerated and developed multi-aged stands and that protection completely altered the composition of the undergrowth: shrubs and palatable forbs dominated inside the exclosures, whereas non-native grasses resistant to grazing dominated outside. In 3 out of 4 exclosures in Colorado's Rocky Mountain National Park, where deer and elk are the primary herbivores, aspen developed multi-aged stands while areas outside did not (Hess 1993, Baker et al. 1997). In South Dakota, aspen in Custer State Park expanded into grasslands where wildlife were excluded (Hoffman and Alexander 1987), and aspen in Wind Cave National Park develop multi-size class stands after exclusion of wild ungulates (Kay 1990).

From study of 4 exclosures in Alberta's Elk Island National Park where elk and moose are the major herbivores, Milner (1977) concluded that not only was aspen regeneration restricted by browsing, but palatable shrubs were more abundant under protection. Trottier and Fehr (1982), evaluating exclosures in Canada's Banff National Park, concluded that aspen regeneration was limited by elk browsing and that protected plots had both greater shrub density and more diverse height than the unprotected plots. Comparing repeat photographs taken of an exclosure (after 50 years protection) near Banff, Kay et al. (1994) observed that a dense multi-aged aspen stand had grown up inside the exclosure while no aspen stems had regenerated successfully outside. These same authors also reported that aspen regenerated successfully where protected for approximately 10-years within the game-proof fenced Trans Canada Highway right-of-way through Banff's lower Bow Valley, but did not where elk were free to browse.

The consensus of all of these studies is that deer and elk can significantly hinder aspen regeneration and change understory species composition. Moreover, livestock use has an additive negative effect on aspen regeneration and understory composition. Excessive use by wildlife tends to reduce woody species and palatable forbs. Utilization by mule deer favors native grasses. Excessive elk use has a negative effect on grasslands because elk utilize a broader array of forages than deer (Nelson and Leege 1982). Excessive use by cattle also tends to reduce the abundance of native grasses and increase the amount of non-native species and bare soil.

\section{Climate Change}

The exclosures also demonstrate that climatic variation has had little effect on reproduction in aspen communities compared to that imposed by ungulates. Since the exclosure fence usually bisects a single aspen clone, differences between protected and open areas cannot be a product of either genetics or climate. The more abundant vegetation inside the exclosures, especially on total-exclusion plots, alters the microclimate, but that is an incorporated variable caused by the plant's response to the elimination of ungulate browsing, not the cause of the vegetation's response. Such microclimatic conditions would prevail in any aspen stand not subject to heavy ungulate use, whether in an exclosure or not.

If climatic variation is having an overriding effect on aspen community dynamics as proposed by others (Romme et al. 1995), we would expect aspen inside exclosures in south-central Utah to show signs of stress, especially since many of the exclosures are situated at the lower elevation of aspen or at grassland-aspen ecotones. However, no signs of physiological stress were observed during this study. In fact, the area occupied by aspen has increased inside exclosures at the expense of grasslands (Fig. 3). Baker et al. (1997) reported no correlation between climatic variation and aspen regeneration, while Kay (1990) reported that enclosed aspen in the Yellowstone Ecosystem replaced grasslands even on south-facing hillsides. White et al. (1998) and Kay (1997b) similarly reported no correlation between climate and aspen regeneration in the Canadian Rockies.

\section{Conclusions}

1. Browsing by native and domestic ungulates has hindered aspen regeneration throughout south-central Utah.

2. Aspen need not always be burned or clear-cut to regenerate successfully.

3. Wild ungulates, primarily mule deer, can have a major effect on aspen stem dynamics and understory composition.

4. Livestock grazing, as historically practiced in southern Utah, has had widespread effects on aspen communities, including changes in understory species composition.
5. Combined wildlife-livestock use most severely alters aspen community dynamics.

6. Aspen stands in the Rocky Mountain west dominated by old or single-age trees are most likely a product of excessive ungulate browsing.

7. Managers should quantify the level of ungulate herbivory before treating aspen stands with fire or cutting, because developing suckers may be subject to repeated browsing. If ungulate browsing is excessive, treatment of aspen stands may only hasten their demise.

\section{Literature Cited}

Baker, F.S. 1925. Aspen in the central Rocky Mountain region. USDA Agr. Bull. No. 1291.

Baker, W.L., J.A. Monroe, and A.E. Hessl. 1997. The effects of elk on aspen on the winter range in Rocky Mountain National Park. Ecography 20:155-165.

Bartos, D.L. and R.B. Campbell, Jr. 1998. Decline of aspen in the interior West-examples from Utah. Rangelands. 20:17-24.

Bartos, D.L. and W.F. Mueggler. 1981. Early succession in aspen communities following fires in western Wyoming. J. Range Manage. 34:315-318.

Bartos, D.L., J.K. Brown, and G.D. Booth. 1994. Twelve years biomass response in aspen communities following fire. J. Range Manage. 47:79-83.

Coles, F.H. 1965. The effects of big game and cattle grazing on aspen regeneration. M.S. Thesis, Brigham Young Univ., Provo, Utah.

Daubenmire, R. 1959. A canopy-coverage method of vegetational analysis.Northwest Sci. 33:43-64.

Despain, D.G., D. Houston, M. Meagher, and P. Schullery. 1986. Wildlife in transition: Man and nature on Yellowstone's northern range. Roberts Rinehart Inc., Boulder, Colo.

Hess, K. Jr. 1993. Rocky times in Rocky Mountain National Park: An unnatural history. University Press of Colorado, Niwot, Colo.

Hoffman, G.R. and R.A. Alexander. 1987. Forest vegetation of the Black Hills National Forest of South Dakota and Wyoming: A habitat type classification. USDA Forest Serv. Res. Paper RM-276. Fort Collins, Colo.

Houston, D.B. 1973. Wild fires in northern Yellowstone National Park. Ecol. 54:1111-1117.

Jones, J.R. and G.A. Schier. 1985. Growth pp. 19-24 In: Debyle, N.V. and R.P. Winokur eds. Aspen: Ecology and Management in the Western United States. U.S. Forest Service Gen. Tech. Rep. RM119. $382 \mathrm{pp}$.

Julander, O. and J.B. Low. 1976. A historical account and present status of the mule deer in the West. p. 3-19. In: Workman, G.W. and J.B. Low, (eds.), Mule deer decline in the West: A symposium. Utah State Univ. Agr. Exp. Sta., Logan, Utah. 
Kay, C.E. 1990. Yellowstone's northern elk herd: A critical evaluation of the "natural regulation" paradigm. Ph.D. Diss., Utah State Univ., Logan, Utah.

Kay, C.E. 1997a. Is aspen doomed? J. Forest. 95:4-11.

Kay, C.E. 1997b. The condition and trend of aspen, Populus tremuloides, in Kootenay and Yoho National Parks: Implications for ecological integrity. Canad. Field-Nat. 111:607-616.

Kay, C.E., and C.W. White. 1995. Long-term ecosystem states and processes in the central Canadian Rockies: A new perspective on ecological integrity and ecosystem management. p. 119-132. In: Linn, R.M.,( ed.) Sustainable society and protected areas. The George Wright Society, Hancock, Mich.

Kay, C.E., B. Patton, and C. White. 1994. Assessment of long-term terrestrial ecosystem states and processes in Banff National Park and the Central Canadian Rockies. Resource Conservation, Parks Canada, Banff National Park, Banff, Alberta.

Krebill, R.G. 1972. Mortality of aspen on the Gros Ventre elk winter range. USDA Forest. Serv. Res. Paper INT-129. Ogden, Utah.

Laycock, W.A. 1969. Exclosures and natural areas on rangelands in Utah. USDA For. Serv. Res. Paper INT-62. Ogden, Utah.

Laycock, W.A. 1975. Rangeland reference areas. Soc. for Range Manage., Range Sci. Series 3.

McDonough, W.T. 1979. Quaking aspen seed germination and early seedling growth. USDA Forest Serv. Res. Paper INT-234. Ogden, Utah.

Milner, B.J. 1977. Vegetation analysis of ungulate range exclosures, Elk Island National Park. Canadian Wildlife Serv., Edmonton, Alberta.
Mueggler, W.F. 1988. Aspen community types of the Intermountain region. USDA Forest. Serv. Gen. Tech. Rep. INT-250. Ogden, Utah. Mueggler, W.F. 1989. Age distribution and reproduction of aspen stands in the Intermountain Region. West. J. Appl. Forest. 4:41-45.

Mueggler, W.F. and D.L. Bartos. 1977. Grindstone Flat and Big Flat exclosures-a 41-year record of changes in clearcut aspen communities. USDA Forest Serv. Res. Paper INT-195. Ogden, Utah.

Nelson, J.R. and T.A. Leege. 1982. Nutritional requirements and food habits. p. 323-367. In: Thomas, J.S. and D.E. Toweill, (eds.), Elk of North America: Ecology and management. Stackpole Books, Harrisburg, Penn.

Olmsted, C.E. 1979. The ecology of aspen with reference to utilization by large herbivores in Rocky Mountain National Park. p. 89-97. In: Boyce, M.S., and L.D. Hayden-Wing, (eds.), North American elk: Ecology, behavior, and management. Univ. of Wyoming, Laramie, Wyo.

Romme, W.H., M.G. Turner, L.L. Wallace, and J.S. Walker. 1995. Aspen, elk, and fire in northern Yellowstone National Park. Ecol. 76:2097-2106.

Sampson, A.W. 1919. Effect of grazing upon aspen reproduction. USDA Bull. No.741.

Shepperd W.D. and F.W. Smith. 1993. The role of near-surface lateral roots in the life cycle of aspen in the central Rocky Mountains. For. Ecol. and Manage. 61:157-170.

Shepperd, W.D. and M.L. Fairweather. 1994. Impact of large ungulates in restoration of aspen communities in a southwestern ponderosa pine ecosystem. p. 344-347. In: Covington, W.S., and L.F. DeBano, (eds.), Sustainable ecological systems: Implementing an ecological approach to land management. USDA Forest Serv. Gen. Tech. Rep. RM-247. Fort Collins, Colo.
Smith, A.D., P.A. Lucas, C.O. Baker, and G.W. Scotter. 1972. The effects of deer and domestic livestock on aspen regeneration in Utah. Utah Division of Wildlife Resources Pub. 72-1. Salt Lake City, Utah.

Sokal, R.R. and F.J. Rohlf. 1981. Biometry: The principles and practice of statistics in biological research. 2nd ed. W.H. Freeman and Co., San Francisco, Calif.

Trottier, G.C. and A. Fehr. 1982. Re-evaluation of four range exclosures in Banff National Park, 1981. Canadian Wildlife Service, Edmonton, Alberta.

U.S. Forest Service. 1937. Range plant handbook. USDA, Forest Service, Washington, D.C. $841 \mathrm{pp}$

U.S. Forest Service. 1995. Environmental assessment for revised east slope cattle allotment management. Dixie National Forest, Teasdale, Utah.

Wallmo, O.C., and W. L. Regelin. 1981. Rocky mountain and intermountain habitats. Part 1. Food habits and nutrition. pp. 387-398 in Wallmo, O.C., ed. Mule and blacktailed deer of North America. Univ. of Nebraska Press, Lincoln, Nebr. 605 pp.

Weatherill, R.G. and L.B. Keith. 1969. The effect of livestock grazing on an aspen forest community. Alberta Dept. of Lands and Forests, Fish and Wildlife Div. Tech. Bull. No. 1. Calgary, Alberta.

White, C.A., C.E. Olmstead, and C.E. Kay. 1998. Aspen, elk, and fire in the Rocky Mountain national parks of North America. Wildl. Soc. Bull. 26:449-462.

Young, S. 1956. Survey and evaluation of big game exclosures in Utah. Utah State Dept. of Fish and Game, Federal Aid Division, Dept. Inform. Bull. No. 24. Salt Lake City, Utah. 


\title{
Herpetofaunal responses to brush management with herbi- cide and fire
}

\author{
BOB JONES, STANLEY F. FOX, DAVID M. LESLIE, JR., DAVID M. ENGLE, AND ROBERT L. LOCHMILLER
}

Authors are former graduate teaching assistant and professor, Department of Zoology; unit leader, U.S. Geological Survey, Biological Resources Division, Oklahoma Cooperative Fish and Wildlife Research Unit; professor, Department of Plant and Soil Sciences; and professor, Department of Zoology, Oklahoma State University, Stillwater, Okla. 74078. Reprint requests should be sent to S. F. Fox.

Abstract

We examined how native herpetofauna of the Cross Timbers in Oklahoma, USA, were influenced by vegetation types derived from combinations of herbicide applications and prescribed burning. Brush management treatments consisted of tebuthiuron $(\mathrm{N}-$ [5-(1,1-dimethylethyl)-1,3,4-thiazol-2-y-1]-N,N'-dimethylurea)only, tebuthiuron + fire, and untreated pastures of mature hardwood forest (no herbicide or fire). A total of 292 individuals representing 30 species was captured in 1994 and 1995 using timeconstrained searching and drift-fence arrays on 3 replicates of the 3 treatments. Relative total abundance and species richness of herpetofauna were similar on all 3 treatment types. However, differences were apparent by taxonomic group. In general, amphibians were most abundant in untreated and tebuthiuron-only pastures, lizards were most abundant on the untreated pastures, and snakes were most abundant on pastures treated with tebuthiuron + fire. Maintenance of a mosaic of habitats in the Cross Timbers may enhance diversity of the native herpetofauna.

Key Words: reptiles, amphibians, brush management, tebuthiuron, prescribed burning, Cross Timbers, Oklahoma.

The Cross Timbers is a western extension of the oak-hickory ecoregion and contains about 19 million ha of upland hardwood forest and tallgrass prairie in the central United States (Garrison et al. 1977, Soil Conserv. Serv. 1981). Livestock production in these oak-dominated rangelands is relatively limited because of low production of herbaceous forage (Scifres 1980). Brush management can increase production of herbaceous forage by selectively removing woody overstory species; this benefits livestock production (Scifres and Mutz 1978, Stritzke 1980, McCollum et al. 1987) and economic returns (Bernardo and Engle 1990, Bernardo et al. 1992).

There are no published studies that directly address effects of brush management on native herpetofauna, but a few studies from the western United States have revealed that abundances of lizards and snakes were reduced in areas that were either grazed by livestock or modified by humans (Busack and Bury 1974, Berry 1978, Jones 1981, 1988, Szaro et al. 1985, Bock et al. 1990). Our research in the Cross Timbers of central Oklahoma

The study was funded by the Departments of Zoology and Plant and Soil Sciences, Oklahoma State University, and the Oklahoma Cooperative Fish and Wildlife Research Unit (Okla. Dep. Wildl. Conserv., Okla. State Univ., U.S. Geol. Surv. Biol. Resour. Div., and Wildl. Manage. Inst., cooperating). We gratefully acknowledge the suggestions from the late G. L. Kirkland, Jr. This is a journal article of the Oklahoma Agricultural Experiment Station.

Manuscript accepted 30 May 1999.

\section{Resumen}

Examinamos como la herpetofauna nativa de los Cross Timbers de Okla., USA, fue influenciada por los tipos de vegetación derivados de combinaciones de tratamientos de herbicida y quemas prescritas. Los tratamientos de manejo de mata fueron tebuthiuron (N-[5-(1,1-dimethylethyl)-1, 3, 4-thiazol-2-y-1]-N, $N^{\prime}$-dimethylurea)-sólo, tebuthiuron + quema, y pastizales no tratados de bosque caducifolio maduro (no herbicida ni quema). Un total de 292 individuos representantes de 30 especies fueron capturados en 1994 y 1995 por medio de búsquedas de tiemporestringido y matrices de cercas de desvío en tres réplicas de los tres tratamientos. La abundancia relativa total y la riqueza de las especies de la herpetofauna fueron parecidas en los tres tipos de tratamiento. Sin embargo, se vieron diferencias por grupo taxonómico. Por lo general, los anfibios fueron más abundantes en los pastizales no tratados y los de tebuthiuron-sólo, las lagartijas fueron más abundantes en los pastizales no tratados, y las culebras fueron más abundantes en los pastizales tratados de tebuthiuron + quema. El mantenimiento de un mosaico de hábitat en los Cross Timbers puede fomentar la diversidad de la herpetofauna nativa.

showed that modification of this habitat with herbicides and fire can have both deleterious and favorable effects on native biota. Generally, eastern cottontail rabbits (Sylvilagus floridanusLochmiller et al. 1991, 1995), cotton rats (Sigmodon hispidus tex ianus-McMurry et al. 1994), and white-tailed deer (Odocoileus virginianus-Soper et al. 1993a, 1993b, Leslie et al. 1996) responded positively to annual burning as part of the brush management prescription. Conversely, occurrence and numbers of some avian species [e.g., Louisiana waterthrush (Seiurus motacil la), tufted titmouse (Parus bicolor)] were impacted negatively by habitat alterations associated with brush control (Schultz et al. 1992a, 1992b).

Landowners likely will continue to convert the Cross Timbers into grasslands (Boren et al. 1996), so it is important to understand effects of such conversion on wildlife populations. Our objective was to determine effects of derived habitat types resulting from brush management with herbicide and fire on populations of reptiles and amphibians in the Cross Timbers.

\section{Study Area and Methods}

We conducted our study on the Cross Timbers Experimental Range (CTER), located about $12 \mathrm{~km}$ southwest of Stillwater, Okla. ( $36^{\circ} 02^{\prime} 40^{\prime \prime}$ to $36^{\circ} 04^{\prime} 20^{\prime \prime} \mathrm{N}, 97^{\circ} 09^{\prime} 30^{\prime \prime}$ to $\left.97^{\circ} 11^{\prime} 39^{\prime \prime} \mathrm{W}\right)$. The 
CTER is a 648-ha research facility that lies near the western edge of the Cross Timbers ecoregion (Kuchler 1964). Upland forest of the CTER is dominated by post oak (Quercus stellata Wangenh.) and blackjack oak (Q. marilandica Muenchh.) in the overstory, interspersed with a mosaic of tallgrass prairie (Ewing et al. 1984). The understory is predominantly eastern redcedar (Juniperus virginiana L.), American elm (Ulmus americana L.), redbud (Cercis canadensis L.), poison ivy (Rhus radicans L.), and rough-leaf dogwood (Cornus drummondii Meyer). The predominant herbaceous ground cover is little bluestem [Andropogon scoparius (Michx.) Nash], but rosette panicgrass (Panicum oligosanthes Schultes), indiangrass [Sorghastrum nutans (L.) Nash], and western ragweed (Ambrosia psilostachya D.C.) occur in varying amounts throughout the CTER. Bottomland forest is restricted to intermittent stream drainages that transect the study area (Ewing et al. 1984).

The CTER was established in 1983 to evaluate responses of livestock and vegetation to various brush management techniques. It was divided into 20, 32.4-ha $(0.41 \times 0.79 \mathrm{~km})$ fenced experimental pastures that represented 4 replicates of 5 treatments comprising 2 herbicides and prescribed burning. Herbicide + fire treatments were burned annually for 3 years starting in 1985 and then on a 3-year rotation starting in 1990. Both herbicides were effective, although pastures treated with tebuthiuron (N-[5-(1,1-dimethylethyl)1,3,4-thiadiazol-2-yl]-N,N'-dimethylurea) resulted in the greatest tree kill of 52-99\% (Stritzke et al. 1987) and increased herbaceous production (Engle et al. 1991, Stritzke et al. 1991). Untreated habitats had a dense woody canopy, little herbaceous cover, and moderate amounts of woody understory (Engle et al. 1991, Stritzke et al. 1991). Treatments with fire had reduced cover of eastern redcedar (Stritzke et al. 1991), although other woody species were not greatly reduced by fire alone.

All experimental pastures were grazed by beef cows in 1984 and by yearling beef cattle in summer in 1985 and after. Stocking was adjusted annually on individual pastures on the basis of the residue of previous year's end-of-season herbage and expected forage production during the following year with the goal of $50 \%$ utilization of annual forage production (Stritzke et al. 1991).

In 1994 and 1995, we evaluated herpetofaunal communities on 3 of the 5 experimental treatments: (1) soil-applied tebuthiuron herbicide applied at $2 \mathrm{~kg}$ a.i. $\mathrm{ha}^{-1}$ in March 1983; (2) tebuthiuron + fire in spring; and (3) untreated (no herbicide or burning). We chose those treatments because they represented the maximal range of habitats available on the CTER relative to overstory cover and composition of the vegetation (Ewing et al. 1984). Untreated pastures were mature upland oak forest (Fig. 1a); tebuthiuron + fire treatments were open, park-like prairie with a scattering of eastern redcedar (Fig. 1b); and the tebuthiuron-only treatments were a mixed-brush type dominated by eastern redcedar (Engle et al. 1991, Stritzke et al. 1991; Fig. 1c)a derived habitat that was structurally and compositionally similar to dense stands of eastern redcedar that now occur on former prairies and hardwood forests through the south-central Great Plains due to fire supression. Production of grasses and forbs in 1994 and 1995 averaged $20 \mathrm{~kg} / \mathrm{ha}$ in the untreated pastures, 680 $\mathrm{kg} / \mathrm{ha}$ in the tebuthiuron-treated pastures, and $1,250 \mathrm{~kg} / \mathrm{ha}$ in the tebuthiuron + fire pastures (Engle, unpublished data). Canopy cover of woody plants in the upland forests was greatest in the untreated pastures and least in the tebuthiruon + fire pastures (Stritzke et al. 1991; Fig. 1). Woody vegetation in the treated pastures was less spatially homogenous than in the untreated pastures and understory production and composition reflected that variability (Fig. 1). Three of the 4 replicates of each of the 3 selected treatments ( 9 pastures) were chosen at random prior to sampling for reptiles and amphibians. Sampling was conducted only on those areas of experimental pastures that were upland forest prior to herbicide application.

Herpetofauna were sampled monthly from mid-May through early October, 1994, and late-March through early October, 1995. Two capture techniques were used to assess abundances of reptiles and amphibians. During the sampling period in 1994 , we performed time-constrained, search-and-seizure techniques

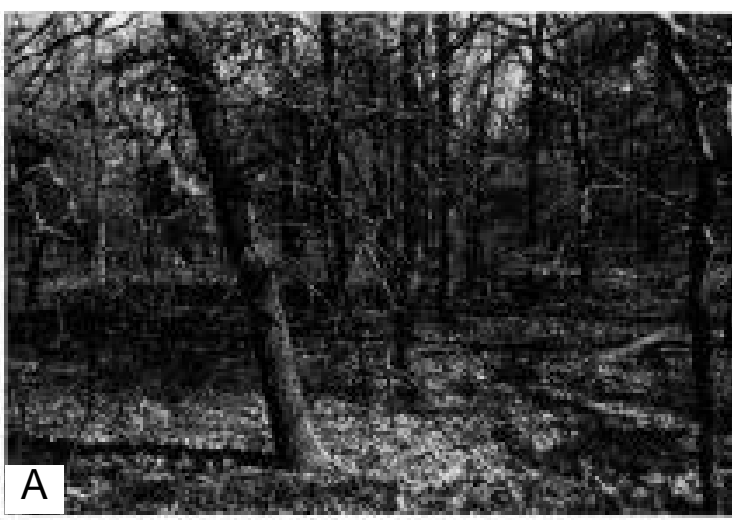

Fig. 1. Habitats in which herpetofauna were studied at the Cross Timbers Experimental Range resulting from the following treatments: a) untreated (no herbicide or fire), b) tebuthiuron + fire, and c) tebuthiuron only.

(Scott 1994). For sampling in 1995, we used both time-constrained searches and drift-fence arrays with funnel traps. Use of drift-fence arrays is a standard effective method of sampling reptiles and amphibians (Scott 1994). Use of standardized drift fences, in combination with searchand-seizure techniques, to assess relative abundance and species richness of reptiles and amphibians facilitates comparisons of experimental units (Enge and Marion 1986, Jones 1986, Bury and Corn 1987). Time-constrained searching allowed counting of species not readily caught in drift-fence arrays or funnel traps (Bury and Corn 1987, Scott 1994).

One drift-fence array was installed on each of the 9 pastures. Each array consist- 
ed of 3, 15.2-m x 30.5-cm lengths of galvanized metal flashing emanating from a central point and radiating out at $120^{\circ}$ angles. One edge of the flashing was buried about $6 \mathrm{~cm}$ below the ground surface, and the fence was stabilized on both sides with $2.5-\mathrm{x} 60-\mathrm{cm}$ wooden stakes placed near the ends and at 5-m intervals. We buried a 19.0-1 plastic drop can flush with the soil surface at the center of the array and at the end of each arm (Campbell and Christman 1982, Vogt and Hine 1982, Corn 1994). When drift fences were not in use, we placed lids on drop cans to prevent entry of animals. To reduce mortality during trapping sessions, lids were propped $10-12 \mathrm{~cm}$ above the drop can to provide shade and ventilation. To avoid confounding treatment effects, drift-fences were placed $\geq 100 \mathrm{~m}$ from treatment boundaries and $\geq 200 \mathrm{~m}$ from permanent water sources. We also placed one double-ended funnel trap constructed of aluminum window screening on each side of each array arm ( $n=6$ funnel traps per array). Funnel traps were $66 \mathrm{~cm}$ long and $16 \mathrm{~cm}$ in diameter with an inside funnel opening of $7 \mathrm{~cm}$ in diameter and were primarily intended for the capture of snakes. Thin rubberized floor mats were cut $30 \mathrm{~cm} \mathrm{x} 45 \mathrm{~cm}$ and were placed over the center of these traps to provide captured animals shelter from the weather. Traps were unbaited, which is standard for herpetofaunal studies.

Monthly drift-fence sampling periods in 1995 lasted 10 days. We checked arrays every second or third day during cool weather (daily high temperature $<25^{\circ} \mathrm{C}$ ) and every other day during hot weather (daily high temperature $>25^{\circ} \mathrm{C}$ ). Captured animals were identified to species, permanently marked by toe or scale clipping, and released at the point of capture. Recaptures were rare and were not included in data tabulations. Time-constrained searching was conducted in 1994 and 1995; each replicate received about 3.5 person-hours of active searching in 1994 and 2.5 person-hours in 1995 . Random encounters and opportunistic observations of reptiles and amphibians also were recorded during monitoring periods if they occurred $\geq 100 \mathrm{~m}$ from pasture boundaries and $\geq 200 \mathrm{~m}$ from permanent water.

Herpetofaunal taxonomic groups were not lumped together because of their differential responses to habitat structure based on their physiological and behavioral capabilities (Jones 1986). Because our data were not normally distributed and sample sizes of some species were small, we used chi-square analyses (SAS 1985) to assess frequencies of captures among treatments by taxonomic group (amphibian and reptile; the latter subdivided into turtle, lizard, and snake) and pooled data across the 3 pasture replicates in each treatment to maximize sample size. We used Kruskal-Wallis tests to evaluate treatment effects on individual species (Anderson et al. 1991). Significance was set at $\mathrm{P} \leq 0.10$.

\section{Results and Discussion}

We captured 292 animals representing 30 species during 2 years of study (Table 1). Thirty-six individuals of 16 species were documented during 32 hours of timeconstrained searching in 1994 (1.1 captures per person-hour). Time-constrained searching during the 1995 season yielded 48 captures of 14 species during 21.5 hours of active searching (2.2 captures per person-hour). The 9 drift-fence arrays and associated funnel traps produced 199 captures during 60 nights of effort (540 arraynights) between late March and early October, 1995 (0.4 captures per arraynight). Nine additional individuals were recorded as chance encounters in 1995.

Herpetofaunal abundance (summed over all 3 replicates) was greatest in untreated pastures $(n=110)$, less in tebuthiuron + fire pastures (95), and least in tebuthiurononly pastures (87) (Table 1). Species richness (summed over all 3 replicates) was similar among pastures: tebuthiuron + fire (22), tebuthiuron-only pastures (21), and untreated pastures (20). Of 30 species, 3 each were unique to untreated pastures and pastures treated with tebuthiuron + fire, and 2 species were found exclusively on tebuthiuron-only pastures (Table 1). Considering individual species, only numbers of the 5-lined skink (Eumeces fascia tus) varied among treatments, being more common on untreated pastures (KruskalWallis $\mathrm{W}=5.45,2 \mathrm{df}, \mathrm{P}=0.07)$.

Numbers of captures of reptiles and amphibians differed among treatments (Table 1). Both taxonomic groups were about equally common on untreated pastures, but amphibians were least common on pastures with tebuthiuron + fire, and reptiles were least common on tebuthiuron-only pastures. Reptile taxa (snakes, turtles, and lizards) also differed significantly among treatments (Table 1). Lizards were more abundant on untreated pastures and were less abundant on tebuthiuron-only plots. Snakes were most abundant in pastures treated with tebuthiuron + fire. Turtles were captured too infrequently for definitive conclusions about their habitat associations.

Amphibians were most abundant on untreated and tebuthiuron-only pastures. They were less common on the most open park-like pastures created with tebuthiuron + fire. Those open pastures were exposed to more insolation and were likely drier, which are conditions generally unfavorable for amphibians. Reptiles, like amphibians, were common on untreated pastures but were more abundant on tebuthiuron + fire pastures than on the dense mixed-brush pastures created by tebuthiuron-only. For the most part, reptiles tolerate drier conditions and bask more than amphibians. Nevertheless, reptile taxa were not uniform in their habitat affiliations. Lizards were least common on the brushiest pastures and were most common on untreated pastures. Skinks, a subgroup of lizards, were most common in untreated pastures, followed by tebuthiuron + fire, and then tebuthiuron-only $\left(\mathrm{X}^{2}\right.$ $=24.00,2 \mathrm{df}, \mathrm{P}<0.01)$. Snakes were most common in open park-like pastures and least so in untreated pastures. Prairie snakes such as the eastern yellowbelly racer (Coluber constrictor) were found exclusively on tebuthiuron + fire treatments. Rough earth snakes (Virginia striatula) also were most abundant on the prairie-like pastures that were treated with either tebuthiuron or tebuthiuron + fire.

Our results indicate that modification of the Cross Timbers with tebuthiuron-only has a negative effect on reptiles in general and lizards in particular. The tebuthiurononly treatment created the least heterogeneous habitats on the CTER and, 10 years post-treatment, was virtually an homogenous forest of eastern redcedar (J. F. Stritzke, pers. comm.), with little structural diversity. Changes in structural heterogeneity due to heavy grazing can reduce abundance and diversity of lizards (Jones 1981). Nevertheless, 2 species of snakes [speckled kingsnake (Lampropeltis getulus) and flathead snake (Tantilla gra cilis)] occurred exclusively on the tebuthiuron-only treatment, although both were represented by a single capture.

We could not analyze the effect of cattle grazing because all the experimental plots were grazed at similar intensity. Other research similar to ours focused on the direct effect of livestock grazing, which in most cases was negative for reptiles and amphibians (Reynolds 1979, Ballinger and Jones 1985, Bock et al. 1990, Fleischner 1994). 
Table 1. Numbers of captures of amphibians and reptiles on untreated and experimental pastures treated with tebuthiuron-only and tebuthiuron + fire at the Cross Timbers Experimental Range, Oklahoma, 1994-1995.

\begin{tabular}{|c|c|c|c|c|c|}
\hline \multirow[b]{2}{*}{ Category } & \multirow[b]{2}{*}{ Common name } & \multirow[b]{2}{*}{ Scientific name } & \multicolumn{3}{|c|}{ Treatments } \\
\hline & & & $\begin{array}{l}\text { Tebuthiuron- } \\
\text { only }\end{array}$ & $\begin{array}{l}\text { Tebuthiuron } \\
+ \text { fire }\end{array}$ & Control \\
\hline \multirow[t]{8}{*}{ Frogs/toads } & American toad & Bufo americanus & 6 & 6 & 19 \\
\hline & Cricket frog & Acris crepitans & 5 & 2 & 7 \\
\hline & Spotted chorus frog & Pseudacris clarkii & 0 & 1 & 1 \\
\hline & Strecker's chorus frog & Pseudacris streckeri & 1 & 0 & 1 \\
\hline & Great Plains & & & & \\
\hline & narrowmouth toad & Gastrophryne olivacea & 7 & 9 & 6 \\
\hline & Bullfrog & Rana catesbeiana & 2 & 4 & 1 \\
\hline & Southern leopard frog & Rana utricularia & 30 & 16 & 21 \\
\hline Salamanders & Smallmouth salamander & Ambystoma texanum & 0 & 3 & 0 \\
\hline $\begin{array}{l}\text { Total number of } \\
\text { amphibians }(\%)^{1}\end{array}$ & & & $51(35.2)$ & $38(26.2)$ & $56(38.6)$ \\
\hline \multirow[t]{3}{*}{ Turtles } & Red-eared slider & Trachemys scripta & 0 & 0 & 1 \\
\hline & Eastern box turtle & Terrapene carolina & 3 & 1 & 3 \\
\hline & Ornate box turtle & Terrapene ornata & 1 & 1 & 0 \\
\hline $\begin{array}{l}\text { Total number of } \\
\text { turtles }(\%)^{2}\end{array}$ & & & $4(40.0)$ & $2(20.0)$ & $4(40.0)$ \\
\hline \multirow[t]{6}{*}{ Lizards } & Slender glass lizard & Ophisaurus attenuatus & 1 & 1 & 0 \\
\hline & Northern prairie lizard & Sceloporus undulatus & 3 & 7 & 3 \\
\hline & Five-lined skink & Eumeces fasciatus & 2 & 7 & 26 \\
\hline & Great Plains skink & Eumeces obsoletus & 0 & 0 & 1 \\
\hline & Ground skink & Scincella lateralis & 7 & 8 & 12 \\
\hline & Six-lined racerunner & Cnemidophorus sexlineatus & 5 & 6 & 0 \\
\hline \multicolumn{6}{|l|}{ Total number of } \\
\hline lizards $(\%)^{2}$ & & & $18(20.2)$ & $29(32.6)$ & $42(47.2)$ \\
\hline \multirow[t]{13}{*}{ Snakes } & Eastern yellowbelly racer & Coluber constrictor & 0 & 4 & 0 \\
\hline & Ringneck snake & Diadophis punctatus & 0 & 2 & 1 \\
\hline & Eastern hognose snake & Heterodon platyrhinos & 1 & 0 & 1 \\
\hline & Speckled kingsnake & Lampropeltis getula & 1 & 0 & 0 \\
\hline & Coachwhip & Masticophis flagellum & 2 & 2 & 1 \\
\hline & Rough green snake & Opheodrys aestivus & 0 & 1 & 1 \\
\hline & Brown snake & Storeria dekayi & 1 & 1 & 0 \\
\hline & Flathead snake & Tantilla gracilis & 1 & 0 & 0 \\
\hline & Western ribbon snake & Thamnophis proximus & 1 & 3 & 0 \\
\hline & Rough earth snake & Virginia striatula & 6 & 12 & 2 \\
\hline & Smooth earth snake & Virginia valeriae & 0 & 1 & 0 \\
\hline & Copperhead & Agkistrodon contortrix & 0 & 0 & 1 \\
\hline & Timber rattlesnake & Crotalus horridus & 1 & 0 & 1 \\
\hline $\begin{array}{l}\text { Total number of } \\
\text { snakes }(\%)^{2}\end{array}$ & & & $14(29.2)$ & $26(54.2)$ & $8(16.7)$ \\
\hline $\begin{array}{l}\text { Total number of } \\
\text { reptiles }(\%)^{1}\end{array}$ & & & $36(24.5)$ & $57(38.8)$ & $54(36.7)$ \\
\hline $\begin{array}{l}\text { Total number } \\
\text { of captures }\end{array}$ & & & 87 & 95 & 110 \\
\hline $\begin{array}{l}\text { Total number } \\
\text { of species }\end{array}$ & & & 21 & 22 & 20 \\
\hline
\end{tabular}

\section{Management Implications}

Herbicides and prescribed fire are common range management tools, and we expect to see more rangeland of the Cross Timbers modified in this manner in the future (Boren et al. 1996). Our results suggest that the Cross Timbers can be man- aged for both cattle and wildlife by providing a mosaic of habitat types (Leslie et al. 1996) with applications of herbicide and prescribed fire in a spatially diverse pattern leaving some areas with unmodified mature upland forest. Application of tebuthiuron followed by prescribed burning is the most profitable practice for managing hardwood forests of the Cross
Timbers for cattle grazing (Bernardo and Engle 1990, Bernardo et al. 1992). Applying herbicide and burning treatments in a mosaic can increase carrying capacity of livestock and white-tailed deer and the profitability of livestock and lease hunting under multiple-use objectives in the Cross Timbers (Bernardo et al. 1992). The application scale for herbicide and 
burning treatments to optimize habitat for livestock and game species likely would be larger than the scale required for herpetofauna. Spot treatments, generally considered by rangeland managers as illadvised because they lead to overuse by grazing animals, perhaps could be used to enhance herpetofauna habitat under carefully controlled livestock grazing.

No single habitat, derived or not, is universally beneficial to herpetofauna or other wildlife. Herbicide application without fire does not benefit most reptiles, whereas herbicide with fire appears to negatively affect most amphibians. Complete removal of mature oak forest would alter species composition of amphibians and reptiles, and it might cause disappearance of some woodland species [e.g., skinks, (Eumeces spp.) and the copperhead (Agkistrodon contortrix)]. On a broader scale, native prairies in the south-central Great Plains that are now dominated by eastern redcedar due to decades of fire suppression likely have a less rich herpetofauna compared with more structurally diverse habitats, but even those areas appear to provide important habitat for some species.

\section{Literature Cited}

Anderson, D.R., D.J. Sweeney, and T.A. Williams. 1991. Introduction to statistics: concepts and applications. West Publishing Co., St. Paul, Minn.

Ballinger, R.E. and S.M. Jones. 1985. Ecological disturbance in a sandhills prairie: impact and importance to a lizard community on Arapaho prairie in western Nebraska. Prairie Nat. 17:91-100.

Bernardo, D.J. and D.M. Engle. 1990. The effect of manager risk attitudes on range improvement decisions. J. Range Manage. 42:242-249.

Bernardo, D.J., D.M. Engle, R.L. Lochmiller, and F.T. McCollum. 1992. Optimum vegetation management under multiple use objectives in the Cross Timbers. J. Range Manage. 45:462-467.

Berry, K.H. 1978. Livestock grazing and the desert tortoise. Trans. North Amer. Wildl. Nat. Resour. Conf. 43:505-519.

Bock, C.E., H.M. Smith, and J.H. Bock. 1990. The effect of livestock grazing upon abundance of the lizard, Sceloporus scalaris, in southeastern Arizona. J. Herpetol. 24:445-446.

Boren, J.C., D. M. Engle, M.S. Gregory, R.E. Masters, T.G. Bidwell, and V.A. Mast. 1996. Landscape structure and change in a hardwood forest-tallgrass prairie ecotone. J. Range Manage. 50:244-249.

Bury, R.B. and P.S. Corn. 1987. Evaluation of pitfall trapping in northwestern forests: trap arrays with drift fences. J. Wildl. Manage. 51:112-118.
Busack, S.D. and R.B. Bury. 1974. Some effects of off-road vehicles and sheep grazing on lizard populations in the Mojave Desert. Biol. Conserv. 6:179-183.

Campbell, H.W. and S.P. Christman. 1982. Field techniques for herpetofaunal community analysis, p. 193-200. In: N.J. Scott (ed.). Herpetological communities. U.S. Fish and Wildl. Serv. Wildl. Res. Rep. 13.

Corn, P.S. 1994. Straight-line drift fences and pitfall traps, p. 109-117. In: W.R. Heyer, M.A. Donnelly, R.W. McDiarmid, L.C. Hayek, and M.S. Foster (eds.). Measuring and monitoring biological diversity. Standard methods for amphibians. Smithsonian Institution Press, Washington, D.C.

Enge, K.M. and W.R. Marion. 1986. Effects of clearcutting and site preparation on herpetofauna of a north Florida flatwoods. For. Ecol. Manage. 14:177-192.

Engle, D.M., J.F. Stritzke, and F.T. McCollum. 1991. Vegetation management in the cross timbers: response of understory vegetation to herbicides and bruning. Weed Tech. 5:406-410.

Ewing, J.H., J.F. Stritzke and J. Kulbeth. 1984. Vegetation of the Cross Timbers Experimental Range, Payne County, Oklahoma. Oklahoma Agr. Exp. Sta. Res. Rep. P-586.

Fleischner, T.L. 1994. Ecological costs of livestock grazing in western North America. Conserv. Biol. 8:629-644.

Garrison, G.A., A.J. Bjugstad, D.A. Duncan, M.E. Lewis, and D.R. Smith. 1977. Vegetation and environment features of forest amd range ecosystems. U. S. For. Serv. Agr. Handb. No. 475.

Jones, K.B. 1981. Effects of grazing on lizard abundance and diversity in western Arizona. Southwest. Nat. 26:107-115.

Jones, K.B. 1986. Amphibians and reptiles, p. 267-290. In: A.Y. Cooperrider, R.J. Boyd, and H.R. Stuart (eds.). Inventory and monitoring of wildlife habitat. U.S. Dept. Interior, Bur. Land Manage., Denver, Colo.

Jones, K.B. 1988. Comparison of herpetofaunas of a natural and altered riparian ecosystem, $\mathrm{p}$. 222-227. In: R.C. Szaro, K.E. Severson, and D.R. Patton (eds.). Management of amphibians, reptiles, and small mammals in North America. U.S. For. Serv. Gen. Tech. Rep. RM-166.

Kuchler, A.W. 1964. Potential natural vegetation of the conterminous United States. Amer. Geogr. Soc. Spec. Publ. 36. New York, N.Y.

Leslie, D.M., Jr., R.B. Soper, R.L. Lochmiller, and D.M. Engle. 1996. Habitat use by white-tailed deer on cross timbers rangeland following brush management. J. Range Manage. 49:401-406.

Lochmiller, R.L., J.F. Boggs, S.T. McMurry, D.M. Leslie, Jr., and D.M. Engle. 1991. Response of cottontail rabbit populations to herbicide and fire applications on cross timbers rangeland. J. Range Manage. 44:150-155.

Lochmiller, R.L., D.G. Peitz, S.T. McMurry, D.M. Leslie, Jr., and D.M. Engle. 1995. Alterations in condition of cottontail rabbits (Sylvilagus floridanus) on rangelands following brush management. J. Range Manage. 48:232-239.

McCollum, F.T., D.M. Engle, and J.F. Stritzke. 1987. Brush management on the Cross Timbers Experimental Range: III. Carrying capacity and steer performance. Okla. Agr. Exp. Sta. Res. Rep. 110-113.
McMurry, S.T., R.L. Lochmiller, J.F. Boggs, D.M. Leslie, Jr., and D.M. Engle. 1994. Demographic profiles of populations of cotton rats in a continuum of habitat types. J. Mammal. 75:50-59.

Reynolds, T.D. 1979. Responses of reptile populations to different land management practices on the Idaho National Engineering Laboratory Site. Great Basin Nat. 39:255-262.

SAS. 1985. Procedure's guide. Stat. Analysis Sys., Inc., Cary, N.C.

Schulz, C.A., D.M. Leslie, Jr., R.L. Lochmiller, and D.M. Engle. 1992a. Herbicide effects on cross timbers breeding birds. J. Range Manage. 45:407-411.

Schulz, C.A., D.M. Leslie, Jr., R.L. Lochmiller, and D.M. Engle. 1992b. Autumn and winter bird communities on herbicide-treated cross timbers in Oklahoma. Amer. Midl. Nat. 127:215-223.

Scifres, C.J. 1980. Brush management: principles and practices for Texas and the southwest. Texas A\&M Press, College Station, Tex. 360 p.

Scifres, C.J. and J.L. Mutz. 1978. Herbaceous vegetation changes following applications of tebuthiuron for brush control. J. Range Manage. 31:375-378.

Scott, N.J. 1994. Complete species inventories, p. 78-84. In: W.R. Heyer, M.A. Donnelly, R.W. McDiarmid, L.C. Hayek, and M.S. Foster (eds.). Measuring and monitoring biological diversity. Standard methods for amphibians. Smithsonian Institution Press, Washington, D.C.

Soil Conservation Service. 1981. Land resource regions and major land areas of the United States. Soil Conserv. Serv. Handb. No. 296.

Soper, R.B., R.L. Lochmiller, D.M. Leslie, Jr., and D.M. Engle. 1993a. Nutritional quality of browse after brush management on cross timbers rangeland. J. Ranage Manage. 46:399-410.

Soper, R.B., R.L. Lochmiller, D.M. Leslie, Jr., and D.M. Engle. 1993b. Condition and diet quality of white-tailed deer in response to vegetation management in central Oklahoma. Proc. Okla. Acad. Sci. 73:53-61.

Stritzke, J.F. 1980. Effect of tebuthiuron on herbage production in tallgrass prairies. Southern Weed Sci. Proc. 33:114.

Stritzke, J.F., D.M. Engle, and F.T. McCollum. 1987. Brush management on the Cross Timbers Experimental Range. I. Brush problems and responses to herbicides. Oklahoma Agr. Exp. Sta. Res. Rep. MP-119:99-102.

Stritzke, J.F., D.M. Engle, and F.T. McCollum. 1991. Vegetation management in the Cross Timbers: response of woody species to herbicides and burning. Weed Tech. 5:400-405.

Szaro, R.C., S.C. Belfit, J.K. Aitkin, and J.N. Rinne. 1985. Impact of grazing on a riparian garter snake, p. 359-363. In: R.R. Johnson, C.D. Ziebell, D.R. Patton, P.F. Ffolliott, and F.H. Hamre (eds.). Riparian ecosystems and their management: Reconciling conflicting issues. U.S. For. Serv. Gen. Tech. Rep. RM-120.

Vogt, R.C. and R.L. Hine. 1982. Evaluation of techniques for assessment of amphibian and reptile populations in Wisconsin, p. 201-217 In: N.J. Scott (ed.). Herpetological communities. U.S.Fish and Wildl. Serv. Wildl. Res. Rep. 13. 


\title{
$\mathrm{N}$-alkane as an internal marker for predicting digestibility of forages
}

\author{
RUSSELL E. SANDBERG, DON C. ADAMS, TERRY J. KLOPFENSTEIN, AND RICHARD J. GRANT
}

Sandberg is research associate and Adams is professor, University Nebraska-Lincoln, West Central Research and Extension Center, North Platte, Neb. 69101; Klopfenstein is professor and Grant is associate professor, Animal Science Department, University Nebraska-Lincoln, Lincoln, Neb. 68583-0908.

\section{Abstract}

Independent digestion trials with 5 forages were conducted to compare n-alkane with indigestible acid-detergent fiber (IADF) as internal markers to predict in vivo dry matter digestibility (digestibility). Forages were mixed grasses from subirrigated meadow (meadow), meadow regrowth (regrowth), native range (range), mature mixed grass hay from meadow, and alfalfa (Medicago sativa L.) hay. Meadow, regrowth, and range diets were immature grasses harvested 0.5 hours before feeding. Feces from the meadow hay and alfalfa hay trials were divided to compare freeze drying and oven drying $\left(60^{\circ} \mathrm{C}\right)$. All diets were subjected to in vitro fermentation for 0,48 , or 96 hours. $\mathrm{N}$-alkane was separated from samples by 4.5 -hour saponification with alcoholic KOH followed by extraction with n-hexane. Indigestible ADF was measured by 96-hour in vitro fermentation followed by ADF extraction. Digestibility estimated by markers was compared with in vivo digestibilities. $\mathbf{N}$-alkane based digestibilities were lower $(P<0.01)$ than in vivo digestibility for all diets. $\mathrm{N}$ alkanes provided higher estimates of digestibilities than IADF for meadow $(P<0.01)$, regrowth $(P=0.06)$, and alfalfa hay $(P=$ $0.06)$, and lower digestibility for meadow hay $(P=0.02)$. Digestibilities calculated using n-alkanes for range tended to be higher $(P=0.14)$ than IADF values. Freeze drying increased $(P<0.01)$ the amount of $n$-alkane extracted from alfalfa hay, but did not affect $(P=0.1)$ the amount extracted from meadow hay. $\mathrm{N}$-alkane disappeared $(\mathrm{P}<0.001)$ from residue collected after 48 hours of in vitro fermentation, but no additional disappearance $(P=0.78)$ was evident at 96 hours. Neither marker was completely recoverable, although recovery of $n$-alkane was higher than indigestible ADF for 4 of the 5 forages tested.

Key Words: indigestible, ADF, hydrocarbon, beef cattle

In vitro dry matter disappearance and internal markers such as indigestible acid-detergent fiber (IADF) and lignin are common methods for estimating forage digestibility in cattle. However, these methods often fail to accurately predict in vivo digestibility (Galyean et al. 1986). Mayes et al. (1986) proposed that long chained hydrocarbons (n-alkanes) may accurately predict in vivo digestibility.

Naturally occurring n-alkanes found in most pasture species contain odd-numbered carbon chains with 25 to 35 carbon atoms. Because fecal recovery of $n$-alkanes improves with increasing

Published with the approval of the director of the University Nebraska-Lincoln, Institute of Agr. and Natur. Resources, Agric. Res. Div. as Journal Ser. No. 12440.

Manuscript accepted 30 May 1999.
Resumen

Se condujeron ensayos individuales de digestibilidad con 5 forrajes para comparar el n-alcano con la fibra indigestible ácidodetergente (IADF) como marcadores internos para predecir la digestibilidad in vivo de la materia seca (digestibilidad). Los forrajes evaluados fueron: zacates mezclados de una pradera subirrigada (pradera), rebrote de la pradera (rebrote), pastizal nativo (pastizal), heno de zacates mezclados maduros de la pradera y heno de alfalfa (Medicago sativa L.). Las dietas de pradera, rebrote y pastizal consistieron de zacates inmaduros cosechados 0.5 horas antes de ofrecerlos como alimento. Las heces fecales de los ensayos de los henos de pradera y alfalfa se dividieron para comparar el secado por congelamiento y el secado en horno (600 C). Todas las dietas se sometieron a fermentación in vitro por $\mathbf{0}$, 48 y 96 horas. El n-alcano fue separado de las muestras mediante una saponificación de $\mathbf{4 . 5}$ horas con $\mathrm{KOH}$ alcohólico seguido por una extracción con n-hexano. La ADF indigestible se midió mediante una fermentación in vitro de 96 horas seguida por la extracción de ADF. La digestibilidad estimada por los marcadores se comparó con las digestibilidades in vivo. En todas las dietas, la estimación de la digestibilidad basada en n-alcano fue menor $(P<0.01)$ que la digestibilidad in vivo. Las estimaciones de digestibilidad obtenidas con n-alcanos fueron mayores que las obtenidas con IDAF, esto para pradera $(P<0.01)$, rebrote $(P=$ 0.06) $y$ heno de alfalfa $(P=0.06), y$ menor para heno de pradera $(P=0.02)$. Las digestibilidades del pastizal calculadas usando $n$ alcano tendieron a ser mayores $(P=0.14)$ que los valores obtenidos con IADF. El secado por congelamiento aumento $(P<$ 0.01) la cantidad de n-alcano extraída del heno de alfalfa, pero no afecto $(P=0.01)$ la cantidad extraída del heno de pradera. El n-alcano desapareció ( $P$ < 0.001$)$ del residuo colectado después de 48 horas de fermentación in vitro, pero no se evidencio una mayor desaparición de n-alcano en la fermentación de 96-horas. Ningún marcador fue completamente recuperable, aunque la recuperación de n-alcano fue mayor que la IADF en 4 de los 5 forrajes evaluados.

chain length, tritriacontane $\left(\mathrm{C}_{33} \mathrm{H}_{68}\right)$ is commonly used to estimate digestibility (Mayes et al. 1986a). Tritriacontane and penttriacontane $\left(\mathrm{C}_{35} \mathrm{H}_{72}\right)$ are not present in some tropical forages (Laredo et al. 1991). However, there is evidence that long chain $\mathrm{n}$-alkanes disappear during gastrointestinal passage (Mayes et al. 1986). Mayes et al. (1988) determined in sheep that a site of disappearance of $n$-alkanes is from the small intestine. In contrast, with dairy cattle Ohajuruka and Palmquist (1991) estimated that $15 \%$ of a ruminally infused synthetic n-alkane marker disappeared in the rumen. To correct for incomplete recovery of $n$ alkane markers in the feces, Mayes et al (1986) proposed dosing 
animals twice daily with synthetic evenchained n-alkanes. However, for many studies on range or pasture, dosing of synthetic n-alkanes may not be practical. Little is known on how method of drying (i.e., oven vs. freeze drying) affects nalkane extraction from samples. Objectives of this study were to: 1) identify which n-alkanes were present in sufficient quantities to be used as internal markers for range, meadow and alfalfa, 2) compare the effectiveness of n-alkane with IADF in estimating in vitro and in vivo digestibility when externally dosing an even-chain n-alkane is not practical because of pasture size and animal distribution, 3) determine if n-alkane disappearance occurs in the rumen, and 4) evaluate effects of different drying methods on nalkane extraction.

\section{Material and Methods}

\section{Animals and Feeding}

Five yearling steers (body weight $=425$ $\mathrm{kg} \pm 13$ ) were housed individually in $3 \times 3$ $\mathrm{m}$ pens for 5 independent digestion trials using immature mixed grasses from subirrigated meadow (meadow), meadow regrowth (regrowth), and native sandhills range (range), mature mixed grass hay from meadow, and alfalfa (Medicago sati va L.) hay. Meadow, range, and meadow regrowth trials were conducted in 1995 using vegetative grasses, beginning 1 June, 1 July, and 15 July, respectively, at the Gudmundsen Sandhills Laboratory located $11 \mathrm{~km}$ northeast of Whitman, Neb. The meadow hay and alfalfa hay trials were conducted in September 1996 at the West Central Research and Extension Center, North Platte, Neb.

Dominant vegetation for the meadow, meadow regrowth, and meadow hay was Kentucky bluegrass (Poa pratensis L.), slender wheatgrass [Elymus trachycaulum (Link) Gould ex Shinn.], quackgrass [Elytergia repens (L.) Nevski], redtop (Agrostis stolonifera L.), timothy (Phleum pratense L.), several species of sedges (Carex spp.), smooth bromegrass (Bromus inermis Leyss.), and reed canarygrass (Phalaris arundinacea L.). Other common species were prairie cordgrass (Spartina pectinata Link), rushes (Juncus spp. and Eleocharis spp.), big bluestem (Andropogon gerardii Vitman), indiangrass [Sorgastrum nutans (L.) Nash], switchgrass (Panicum virgatum L.), and several species of clover (Trifolium $\mathrm{spp}$ ).

The forage collected from the range site was dominated by warm-season grasses, including little bluestem [Schizachyrium scoparium (Michx.) Nash], prairie sandreed [Calamovilfa longifolia (Hook.) Scribn.], sand bluestem (Andropogon hal lii Hack.), and switchgrass (Panicum vir gatum L.). Other common species were blue grama [Bouteloua gracilis(H.B.K.) Lag. ex Griffiths], hairy grama (Bouteloua hirsuta Lag.), sand dropseed [Sporobolus cryptandrus (Torr.) Gray], prairie junegrass [Koeleria pyramidata (Lam.) Beauv.], needleandthread (Stipa comata Trin. \& Rupr.), western ragweed (Ambrosia psilostachya DC.), Schweinitz flatsedge (Cyperus schweinitzii Torr.), and sun sedge (Carex heliophila Mack.). More detail of meadow and range vegetation and soils is given by Adams et al. (1998).

Each trial consisted of a 10-day diet adaptation period followed by 5 days of total fecal collection. Each forage was limit-fed twice daily at $1.0 \%$ of body weight per feeding with the forage from meadow, meadow regrowth, and range harvested 0.5 hours before feeding. Feed samples were collected and frozen before each feeding. Refusals were collected and frozen before the morning feeding, and feces were collected and frozen twice daily.

\section{Laboratory analysis}

Diets, refusals, and feces from each trial were freeze dried and ground in a Wiley Mill to pass through a 1-mm screen. Samples were composited by dry weight across days on an individual animal basis. Feces from the meadow hay and alfalfa hay trials were subsampled and either freeze dried or dried in a forced air oven $\left(60^{\circ} \mathrm{C}\right)$ to compare the effect of drying method on n-alkane extraction. Laboratory analyses included dry matter, organic matter (AOAC 1990), and IADF (Berger et al. 1979, Cochran et al. 1986) for all samples and NDF (Van Soest et al. 1991), ADF (Van Soest 1963), crude protein (AOAC 1990), and in vitro dry matter disappearance (Tilley and Terry 1963) using modified procedures as described by Hollingsworth-Jenkins et al. (1996) for the diet samples.

Hentriacontane disappearance in the rumen was examined by using a modified Tilley and Terry (1963) method for in vitro dry matter disappearance. Samples weighing 1.8 $\mathrm{g}$ were measured into three , 30-ml polypropylene in vitro tubes in $0.6 \mathrm{~g}$ increments, inoculated with a mixture of rumen fluid:McDougall's buffer (McDougall 1948), and incubated in a $39^{\circ} \mathrm{C}$ water bath for either 48 or 96 hours. The contents from the 3 tubes were filtered through filter paper (Whatman ${ }^{1}$ 541), and the residues were combined to form a single sample and saved for later n-alkane analysis.

\section{Alkane Analysis}

Subsamples weighing either $1 \mathrm{~g}$ for feces or $2 \mathrm{~g}$ for forage were placed in a $75-\mathrm{ml}$ tube (fitted with a screwcap and teflon liner) with $0.6 \mathrm{ml}$ of a 1,000 $\mathrm{mg} / \mathrm{liter}^{-1}$ solution of dotriacontane $\left(\mathrm{C}_{32}\right.$ $\mathrm{H}_{66}$ ) n-hexane as an internal standard. Each tube was then placed in a $90^{\circ} \mathrm{C}$ water bath to saponify samples for 4.5 hours with $10 \mathrm{ml}$ alcoholic $\mathrm{KOH}$. After saponification, liquid-liquid extraction was performed by adding $7 \mathrm{ml}$ of $\mathrm{n}$-hexane and 2 $\mathrm{ml}$ of $\mathrm{H}_{2} \mathrm{O}$, shaking vigorously, centrifuging $(1,000 x \mathrm{x}$ for $10 \mathrm{~min})$, and transferring the n-hexane layer to a prepared column for solid phase separation. The column was prepared by first placing $2 \mathrm{~g}$ of silicic acid per column in a $110^{\circ} \mathrm{C}$ oven to activate the silicic acid. Then the silicic acid was suspended in solution using $10 \mathrm{ml}$ of $\mathrm{n}$-hexane and placed in an extraction column. The extract eluted from the column was evaporated to dryness, reconstituted with $2 \mathrm{ml}$ of $\mathrm{n}$-hexane, and placed into a glass vial for later analysis using gas chromatography. Ten samples from the meadow, meadow regrowth, and range trials selected randomly were reconstituted with $2 \mathrm{ml}$ of a triacontane $\left(\mathrm{C}_{30} \mathrm{H}_{26}\right)$ standard ( $0.3 \mathrm{mg}$ per $\mathrm{ml}$ of $\mathrm{n}$-hexane) to determine the recovery rate of dotriacontane during the extraction procedure.

\section{Calculations and Statistical Analysis}

In vivo DMD and estimated values of DMD using IADF and n-alkanes as internal markers were calculated following procedures outlined by Schneider and Flatt (1975). N-alkane concentrations were determined using the following formula with $0.6 \mathrm{mg}$ representing $0.6 \mathrm{ml}$ of a standard solution containing $1.0 \mathrm{mg}$ of dotriacontane per $\mathrm{ml}$ of $\mathrm{n}$-hexane:

$$
\begin{gathered}
\text { mg of } \mathrm{n} \text {-alkane/kg sample }=\frac{\text { peak area of alkane }}{\text { peak area of internal standard }} X \\
\frac{0.6 \mathrm{mg} \mathrm{x} 100}{\text { sample weight } \times \text { DM }}
\end{gathered}
$$

Dry matter digestibility coefficients and marker recovery for each trial and drying

\footnotetext{
Whatman Labsales, P.O. Box 1359, Hillsboro, Ore. 97123.
} 
methods for the meadow hay and alfalfa hay trials were analyzed as a randomized complete block, with steers as blocks using the General Linear Model Procedure of SAS (1990).

\section{Results}

Because the n-alkane, tritriacontane, did not produce any detectable peaks using gas chromatography for the freshly harvested forages, the next smaller, odd-chained nalkane, hentriacontane $\left(\mathrm{C}_{31} \mathrm{H}_{64}\right)$, was used. The recovery of the dotriacontane internal standard averaged $82 \%$. The chemical composition of the 5 diets are given in Table 1 . For all 5 diets, digestibility estimates calculated using $n$-alkane ratio were lower $(\mathrm{P}$ $<0.01$ ) than in vivo DMD (Table 2). Comparison of digestibilities estimated using the n-alkane ratios and IADF ratios showed that the n-alkane ratio predicted higher DMD for meadow ( $\mathrm{P}<0.01$ ), meadow regrowth $(\mathrm{P}=0.06)$, and alfalfa hay $(\mathrm{P}$ $=0.06)$, and lower DMD for meadow hay $(\mathrm{P}<0.02)$. Forage digestibilities for native range using n-alkane ratio tended to be higher $(P=0.14)$ than IADF ratio values. Indirect comparisons between in vivo digestibility and digestibilities estimated using an n-alkane and IADF showed that for meadow, range, meadow regrowth, and alfalfa hay, n-alkane provided a better estimate of in vivo digestibility. Intake and fecal output estimates are shown in Table 3.

Although statistical comparisons between in vitro dry matter disappearance and the other methods of estimating digestibility were not possible because in vitro methods produce a single estimate that does not account for the variation between animals, in vitro dry matter disappearance appeared to produce estimates of digestibility comparable to the n-alkane ratio method for the immature, freshly harvested forages and higher estimates for the alfalfa and meadow hay.

Fecal recoveries of hentriacontane and IADF are shown in Table 4. While marker recoveries were not consistent across forages, n-alkane recoveries for the forages that were freshly harvested were higher $(\mathrm{P}$ $<0.02)$ than IADF recoveries. Both markers had similar recoveries for alfalfa hay $(P=0.14)$, and IADF recovery rate was higher for meadow hay $(\mathrm{P}=0.07)$. The amounts of hentriacontane extracted from the meadow hay fecal samples were simi$\operatorname{lar}(\mathrm{P}>0.10)$ for freeze drying $(0.235 \mathrm{~g}$ $\left.\mathrm{kg}^{-1}\right)$ and oven drying $\left(0.240 \mathrm{~g} \mathrm{~kg}^{-1}\right)$. However, freeze drying increased $(\mathrm{P}<$ $0.01)$ the amount of n-alkane extracted

Table 1. Chemical composition of fresh harvested forage from subirrigated meadow, subirrigated meadow regrowth, native sandhills range, mature hay from subirrigated meadow and alfalfa hay diets.

\begin{tabular}{llccccc}
\hline \hline & $\begin{array}{c}\text { Dry } \\
\text { matter }\end{array}$ & $\begin{array}{c}\text { Organic } \\
\text { matter }\end{array}$ & NDF & ADF & $\begin{array}{c}\text { Crude } \\
\text { protein }\end{array}$ & Hentriacontane \\
\hline $\begin{array}{l}\text { Fresh meadow forage } \\
\text { harvested in June }\end{array}$ & 96.1 & 91.4 & 62.8 & 33.0 & 10.3 & 0.076 \\
$\begin{array}{l}\text { Fresh native range forage } \\
\text { harvested in July }\end{array}$ & 96.7 & 93.5 & 70.0 & 32.7 & 11.3 & 0.081 \\
$\begin{array}{l}\text { Fresh meadow regrowth } \\
\text { harvested in July }\end{array}$ & 96.4 & 87.9 & 63.8 & 34.0 & 11.3 & 0.093 \\
$\begin{array}{l}\text { Alfalfa hay } \\
\text { Meadow hay }\end{array}$ & 96.2 & 87.8 & 54.3 & 36.3 & 19.1 & 0.162 \\
Standard error of means & 96.8 & 90.5 & 67.1 & 38.9 & 7.7 & 0.175 \\
\hline
\end{tabular}

Table 2. In vivo, hentricontane, indigestible ADF (IADF), and in vitro dry matter disappearance (IVOMD) calculations of apparent dry matter digestibiliy estimates of fresh harvested forage from subirrigated meadow, subirrigated meadow regrowth and native sandhills range, mature hay from subirrigated meadow, and alfalfa hay.

\begin{tabular}{lcccccc}
\hline \hline Diet & In vivo & $\begin{array}{c}\text { Hentria- } \\
\text { contan }\end{array}$ & $\begin{array}{c}\text { p- } \\
\text { value }^{\mathrm{a}}\end{array}$ & IADF & $\begin{array}{c}\text { p- } \\
\text { value }^{\mathrm{b}}\end{array}$ & $\begin{array}{c}\text { In vitro } \\
\text { DMD }\end{array}$ \\
\hline $\begin{array}{l}\text { Fresh meadow forage } \\
\text { harvested in June }\end{array}$ & 67.5 & 62.9 & 0.004 & 57.2 & 0.001 & 61.5 \\
$\begin{array}{l}\text { Fresh native range } \\
\text { forage harvested in July }\end{array}$ & 70.5 & 61.8 & 0.004 & 58.3 & 0.14 & 58.3 \\
$\begin{array}{l}\text { Fresh meadow regrowth } \\
\text { harvested in July }\end{array}$ & 70.7 & 57.5 & 0.002 & 51.0 & 0.06 & 57.8 \\
$\begin{array}{l}\text { Alfalfa hay } \\
\text { Meadow hay }\end{array}$ & 60.2 & 50.0 & 0.01 & 43.8 & 0.06 & 58.2 \\
Standard error of means & 55.1 & 36.2 & 0.0001 & 42.6 & 0.01 & 47.1 \\
\hline
\end{tabular}

${ }^{\mathrm{a} C o m p a r i s o n}$ between in vivo digestibility and digestibility predicted using hentriacontane.

${ }^{\mathrm{b}}$ Comparison between digestibility predicted using hentriacontane and IADF.

Table 3. Fecal output of dry matter, actual dry matter intake, hentriacontane intake and dry matter intake predicted by hentriacontane used to calculate digestibilities ${ }^{\mathrm{a}}$.

\begin{tabular}{|c|c|c|c|c|}
\hline \multirow[b]{2}{*}{ Diet } & \multicolumn{2}{|c|}{ Intake } & \multicolumn{2}{|c|}{ Fecal Output } \\
\hline & $\begin{array}{l}\text { Hentriacontane } \\
\text { predicted } \\
\text { dry matter }\end{array}$ & $\begin{array}{c}\text { Actual } \\
\text { dry matter }\end{array}$ & Hentriacontane & Dry matter \\
\hline $\begin{array}{l}\text { Fresh meadow forage } \\
\text { harvested in June }\end{array}$ & $\begin{array}{l}\left(\mathrm{kg} \mathrm{day}^{-1}\right) \\
4.8\end{array}$ & $\begin{array}{l}\left(\mathrm{kg} \mathrm{day}^{-1}\right) \\
5.5\end{array}$ & $\begin{array}{l}\left(\mathrm{g} \mathrm{day}^{-1}\right) \\
0.36\end{array}$ & $\begin{array}{l}\left(\mathrm{kg} \mathrm{day}^{-1}\right) \\
1.8\end{array}$ \\
\hline $\begin{array}{l}\text { Fresh native range } \\
\text { forage harvested in July }\end{array}$ & 5.3 & 7.0 & 0.42 & 2.0 \\
\hline $\begin{array}{l}\text { Fresh meadow regrowth } \\
\text { harvested in July }\end{array}$ & 5.8 & 8.5 & 0.50 & 2.4 \\
\hline Alfalfa hay & 6.1 & 7.5 & 1.05 & 3.0 \\
\hline Meadow hay & 5.6 & 8.0 & 1.09 & 3.6 \\
\hline
\end{tabular}

${ }^{\mathrm{a}}$ Data in table is for reader information, no statistics performed.

from alfalfa hay $\left(0.316 \mathrm{~g} \mathrm{~kg}^{-1}\right)$ compared with oven drying $\left(0.249 \mathrm{~g} \mathrm{~kg}^{-1}\right)$.

Hentriacontane amounts found in residues collected by filtration after a 48 hour in vitro fermentation period decreased $(\mathrm{P}<0.001)$ over $0.1 \mathrm{~g} \mathrm{~kg}^{-1}$ (Table 5). However, samples incubated for
96 hours produced residues similar $(\mathrm{P}=$ 0.78 ) to those produced after 48 hours of incubation. In terms of hentriacontane recovery, an average of $18.8 \%$ was recovered for the residues obtained after 48 and 96 hours of incubation. 
Table 4. Recoveries of indigestable acid detergent fiber (IADF) and hentriacontane from the feces of steers fed fresh harvested forage from subirrigated meadow, subirrigated meadow regrowth, native sandhills range, mature hay from subirrigated meadow, and alfalfa hay.

\begin{tabular}{lccc}
\hline \hline Diet & Alkane & IADF & p-value \\
\hline $\begin{array}{l}\text { Fresh meadow forage } \\
\text { harvested in June }\end{array}$ & 87.2 & 75.6 & 0.01 \\
$\begin{array}{l}\text { Fresh native range } \\
\text { forage harvested in July }\end{array}$ & 76.0 & 69.9 & 0.002 \\
$\begin{array}{l}\text { Fresh meadow regrowth } \\
\text { harvested in July }\end{array}$ & 67.6 & 57.9 & 0.02 \\
Alfalfa hay & 80.4 & 71.1 & 0.14 \\
Meadow hay & 70.5 & 78.4 & 0.07 \\
Standard error of means & 5.2 & 5.2 & \\
\hline
\end{tabular}
recoveries. An exception is that hentria-

\section{Discussion and Conclusions}

Although n-alkane recovery increases with increasing chain length (Mayes et al. 1986), hentriacontane was selected as the internal marker to estimate DMD because tritriacontane was not detected in the freshly harvested forages. The inability of tritriacontane to be detected in this study was attributed to lack of column sensitivity where n-alkane amounts less than 20 $\mathrm{mg} \mathrm{kg}^{-1}$ are not detectable. This agrees with Casson et al. (1990) who suggested that odd chain n-alkane concentrations should be at least $50 \mathrm{mg} \mathrm{kg}^{-1} \mathrm{DM}$ for accurate prediction of DMD. Additionally, Laredo et al. (1991) concluded that for some tropical forages tritriacontane was not present in sufficient quantity for intake to be estimated using dotriacontane: tritriacontane ratios.

Although hentriacontane consistently underestimated the in vivo digestibilities for all forages examined, it offered an improvement over digestibilities estimated with IADF for freshly harvested forages. The differences between digestibilities estimated with hentriacontane and IADF can be explained by examining fecal contane and IADF had similar fecal recoveries but different digestibility estimates for alfalfa hay. Fecal recoveries of hentriacontane for freshly harvested range and meadow forages were lower than those reported for hays. In contrast to freshly harvested forages, fecal recovery of hen-

triacontane for alfalfa and meadow hays were within ranges reported for other hays (Dove et al. 1989, Ohajuruka and Palmquist 1991). Differences between digestibilities predicted using hentriacontane and in vitro dry matter disappearance were small for meadow, meadow regrowth, and range.

Cochran et al. (1986) reported that fecal IADF recoveries from animals grazing immature forages are lower than for animals fed mature forages. However, hentriacontane recoveries appeared to be greater for the studies using freshly harvested forage. Additionally, Owens and Hanson (1992) stress that markers be chemically discrete with a specific method of analysis. When comparing the 2 markers, one benefit $n$-alkanes have over IADF is that n-alkanes meet this requirement, because their composition remains the same over a variety of forages. Another concern is IADF can have additional sources of error due to variations found among donor animals and handling of innoculum (Horton et al. 1980, Fahey and Berger 1988).

Replacing freeze-drying of fecal samples with oven drying would decrease the amount of drying time and increase the number of samples handled. While hentriacontane amounts in feces from steers fed meadow hay were not affected by drying method, oven drying reduced the amount of hentriacontane recovered from the feces of steers on an alfalfa hay diet by $20 \%$. In a review of n-alkanes as markers, Dove and Mayes (1991) indicated drying method affects herbage n-alkane concen-

Table 5. Hentriacontane in residue after 0,48 , and 96 hours of in vitro fermentation.

\begin{tabular}{lccc}
\hline \hline Time & Hentriacontane $\mathrm{g} / \mathrm{kg}$ & $\mathrm{SE}^{\mathrm{c}}$ & $\mathrm{p}$-value \\
\hline Control, 0 hours & .184 & 61.8 & \\
48 hours & .031 & 14.9 & $.0002^{\mathrm{a}}$ \\
96 hours & .038 & 10.9 & $.78^{\mathrm{b}}$ \\
\hline
\end{tabular}

${ }^{\mathrm{a}}$ Comparison of control with 48-hour fermentation.

${ }^{\mathrm{b}}$ Comparison of 48- and 96-hour fermentation.

${ }^{\mathrm{c}}$ Standard error of means. trations and that further research was needed to determine the effect of drying method on n-alkane concentrations in feces. During oven drying, the high temperatures may subject hentriacontane to either marker degradation or chemical reactions that make complete extraction difficult. Because hentriacontane concentrations vary with drying methods in both forage and feces, it is recommended that samples should be freeze dried for n-alkane analysis.

In vitro fermentation was used to determine if hentriacontane was degraded in the rumen. Filter paper rated to retain particles greater than $25 \mu \mathrm{m}$ was used to isolate the residue since Mayes et al. (1988) indicated that $\mathrm{n}$-alkanes are associated with the particulate phase of digesta. Initial examination of the results indicated that hentriacontane is highly degraded in the rumen. However, the in vivo studies showed an average total tract recovery of $76.3 \%$. Hentriacontane recovery in the residue left after in vitro fermentation was approximately 60 percentage units lower. While in vitro fermentation could degrade hentriacontane to a greater extent than gastrointestinal passage, large differences are unlikely. Because the hentriacontane amounts found in the residues remained unchanged between the 48-hour and 96hour incubation times, we propose that the low recovery was due to association of the marker with the liquid phase, which was lost during filtration rather than degradation as suggested by Mayes et al. (1988). Further examination is recommended to determine which digesta phase hentriacontane associates with during gastrointestinal passage.

Locating the site of $n$-alkane disappearance is important when evaluating their use as potential internal markers. If disappearance is isolated to the lower tract, the marker may be used to estimate forage dry matter digestibility in the rumen. Faichney (1975) indicated that a marker needs to be intimately associated with the material it is marking. If $n$-alkanes are to be reliable as internal markers, it is important that the digesta phase association of n-alkanes be determined.

We concluded that digestibility was underestimated by n-alkanes and hentriacontane recovery was not consistent across forages. Freeze-drying should be used to dry fecal samples for $n$-alkane analysis. In grazing situations where internal markers are desired, naturally occurring n-alkanes may be a more reliable alternative than IADF for estimating DMD of immature forages. 


\section{Literature Cited}

Adams, D.C., R.T. Clark, P.E. Reece, and J.D. Volesky. 1998. Research and education for managing resources within the Nebraska Sandhills: The Gudmunsen Sandhills Laboratory. Rangelands 20:48.

AOAC. 1990. Official methods of analysis (14th ed.). Association of Official Analytical Chemists. Washington, D.C.

Berger, L., T. Klopfenstein, and R. Britton. 1979. Effect of sodium hydroxide on efficiency of rumen digestion. J. Anim. Sci. 49:1317-1323.

Casson, T., J.B. Rowe, C.W. Thorn, and D. Harris. 1990. The use of natural n-alkanes in medic and clover as indigestible markers. Proc. Australian Soc. Anim. Prod. 18:462.

Cochran, R. C., D.C. Adams, J.D. Wallace, and M.L. Galyean. 1986. Predicting digestibility of different diets with internal markers: Evaluation of four potential markers. J. Anim. Sci. 63:1476-1483.

Dove, H. and R.W. Mayes. 1991. The use of plant wax alkanes as marker substances in studies of the nutrition of herbivores: a review. Australian. J. Agr. Res. 42:913-952.

Dove, H., R.W. Mayes, M. Freer, J.B. Coombe, and J.C. Foot. 1989. Faecal recoveries of the alkanes of plant cuticular waxes in penned and in grazing sheep. p. 1093-1094. XVI Int. Grassl. Congr. Vol. II, Nice, France.

Fahey, G.C. and L.L. Berger. 1988. Carbohydrate nutrition of ruminants. pp. 269-297 In: D.C. Church (ed.), The ruminant animal: Digestive physiology and nutrition. Waveland Press, Inc., Prospect Heights, Ill.
Faichney, G.J. 1975. The use of markers to partition digestion within the gastro-intestinal tract of ruminants. p. 277-291.In: I.W. MacDonald and A.C.I. Warner (ed.), Digestion and metabolism in the ruminant. Univ. of New England Publishing Unit, NSW, Australia.

Galyean, M.L., L.J. Krysl and R.E. Estell. 1986. Marker based approaches for estimation of fecal output and digestibility in ruminants. p. 96-113 In: F.N. Owens (Ed.) Feed Intake by Beef Cattle: Symposium. Oklahoma Agr. Exp. Sta. MP-121, Stillwater,Okla.

Hollingsworth-Jenkins, K.J., T.J. Klopfenstein, D.C. Adams, and J.B. Lamb. 1996. Ruminally degradable protein requirement of gestating beef cows grazing native winter Sandhills range. J. Anim. Sci. 74:1343-1348.

Horton, G.M.J., D.A. Christensen, and G.M. Steacy. 1980. In vitro fermentation of forages with inoculum from cattle and sheep fed different diets. Agron. J. 72:601-605.

Laredo, M.A., G.D. Simpson, D.J. Minson, and C.G. Orpin. 1991. The potential for using $\mathrm{n}$-alkanes in tropical forages as a marker for the determination of dry matter intake by grazing ruminants. J. Agr. Sci. (Camb.). 117:355-361.

Mayes, R.W., C.S. Lamb and P.M. Colgrove. 1986. The use of dosed and herbage n-alkanes as markers for the determination of herbage intake. J. Agr. Sci. (Camb.) 107:161-70.
Mayes, R.W., C.S. Lamb, and P.M. Colgrove. 1988. Digestion and metabolism of dosed even-chain and herbage odd-chain n-alkanes in sheep. p. 159-163. In: Proc. 12th General Meeting of the European Grassl. Federation. European Grassl. Federation: Dublin, Ireland.

McDougall, E.I. 1948. Studies on ruminant saliva. I. The composition and output of sheep's saliva. Biochem. J. 43:99-109.

Ohajuruka, O.A. and D.L. Palmquist. 1991. Evaluation of $\mathrm{n}$-alkanes as digesta markers in dairy cows. J. Anim. Sci. 69:1726-1732.

Owens, F.N. and C.F. Hanson. 1992. Symposium: External and internal markers (External and internal markers for appraising site and extent of digestion in ruminants). J. Dairy Sci. 75:2605-2617.

SAS. 1990. SAS User's Guide: Statistics. SAS Inst. Inc., Cary, N.C.

Schneider, B.H. and W.P. Flatt. 1975. The evaluation of feeds through digestibility experiments. p. 169. Univ. Georgia Press, Athens, Ga.

Tilley, J.M.A. and R.A. Terry. 1963. A two-stage technique for the in vitro digestion of forage crops. J. Brit. Grassl. Soc. 18:104-111.

Van Soest, P.J. 1963. Use of detergents in the analysis of fibrous feeds. 2. A rapid method for the determination of fibre and lignin. J. Assoc. Official Agr. Chem. 46:829-835.

Van Soest, P.J., J.B. Robertson, and B.A. Lewis. 1991. Methods for dietary fiber, neutral detergent fiber, and non starch polysaccarides in relation to animal nutrition. J. Dairy Sci. 74:3583-3597. 


\title{
Spatial distribution of economic change from Idaho ranches
}

\author{
AARON J. HARP, ROBERT R. LOUCKS, AND JAMES N. HAWKINS
}

Authors are assistant professor, Department of Agricultural Economics and Rural Sociology, University of Idaho, Moscow, Ida. 83844-2334; professor, University of Idaho Cooperative Extension System, Lemhi County, Salmon, Ida 83467; professor, University of Idaho Cooperative Extension System, Custer County, Challis, Ida. 83226.

\section{Abstract}

Economic impacts from federal grazing policy frequently figure in public debate about federal land in the American West. The spatial and economic level of aggregation at which impacts are estimated is a significant issue, both politically and methodologically. We present an input/output model incorporating spatial detail at the sub-county level. Seven community-level economies are portrayed and contrasted with the aggregated 2county economy. Our argument is that economic dependencies, notably dependencies on the range cattle industry, differ significantly between communities and that this differentiation is completely masked when the 2 county area is examined as 1 economy. The sub-county breakdown illustrates the degree to which communities are differentially vulnerable to reduced cattle prices and a reduction in available federal forage.

Key Words: Public land, grazing, input/output models

The importance of the range cattle industry to communities in the western U.S. is a frequent topic for local people, policy makers, federal land managers, and the general discussion of public land management. The economic impact of changes in grazing policies on public lands continues to be an important issue. Typically, overall economic impacts are evaluated either with statistics about employment or earnings derived from an industry (Power 1996), with regional economic techniques (Lacy and Johnson 1990), or with econometrics (LaFrance and Watts 1995). Other studies focus on the impact of changes in grazing fees or other land management issues (Torell and Drummond 1997, Bartlett et al. 1979, Cook et al. 1980, Anderson et al. 1993, Torell and Doll 1991, Lambert 1987, Rowan and White 1994). All approaches to estimating economic impacts have limitations. Most approaches can only focus on ranches as a group or on a large region taken as a single area. Given this, a notable limitation of traditional impact studies is the absence of spatial economic detail. Estimation of local economic impacts on communities and their spatial distribution are beyond the capabilities of most methodologies and approaches.

The level of spatial and economic aggregation used to assess policy changes is a significant problem for impact assessment. It is not simply a methodological choice to use a state or county

Research was supported in part by Idaho Experiment Station project IDA01047, and cooperative agreement D030A0003 of U.S. Department of Interior, Bureau of Land Management, Salmon National Forest of U.S. Forest Service, County Commissions of Custer and Lemhi Counties, Ida. This paper is Idaho Agricultural Experiment Station Publication.

Manuscript accepted 31 May 1999.

\section{Resumen}

Los impactos económicos de las políticas federales de apacentamiento frecuentemente figuran en los debates públicos acerca de las tierras federales del oeste Americano. El nivel de agregación espacial y económico al cual los impactos son estimados es un problema significativo, tanto político como metodológico. Aquí presentamos un modelo de entrada/salida en el que se incorpora detalles espaciales al nivel de sub-municipio. Siete economías a nivel de comunidad se describieron y contrastaron con el agregado de 2 economías de municipio. Nuestro argumento es que las dependencias económicas, dependencias notablemente en la industria ganadera de pastizal, difieren significativamente entre comunidades, y que esta diferenciación es completamente enmascarada cuando las 2 áreas municipales se examinan como una sola economía. La separación en sub-municipios ilustra el grado al cual las comunidades son diferencialmente vulnerables a los precios reducidos del ganado y a una reducción del forraje federal disponible.

estimate, for example. The choice has implications for policy in that an impact may be very large for 1 county, but negligible for the state as a whole. Thus, how we approach aggregation frames the policy discussion about the estimated economic consequences of different policy choices. Even county level analysis can mask significant differentiation between community-level economies and this differentiation has direct implications for evaluating the range cattle industry and federal grazing policies.

We use input/output techniques to evaluate the spatial distribution of economic impacts from public land grazing across 7 communities in a 2 county area of central Idaho. Examining the importance of ranching at the 2 county, aggregate level portrays the local economy very differently from the disaggregated community economies of the area. We use this model to illustrate how economic change will be distributed across 7 communities when cattle prices decline or available federal grazing animal unit months (AUMs) are reduced.

\section{Materials and Methods}

Custer and Lemhi Counties in central Idaho are dominated by federal lands: both counties contain over $90 \%$ public land. The U.S. Forest Service and Bureau of Land Management dominate the management of these lands. Local economies have historically depended on ranching, recreation, government, mining, and some timber.

We conducted over 160 semi-structured household interviews for a parallel social assessment. Respondents in these interviews 
helped define numerous assumptions used in the economic models. Respondents defined the trade "hierarchy" used in the economic model. In such a hierarchy, some communities "trade up" to a central trade community from which money "leaks" to larger, outside trade centers. To accomplish this, we asked both personal interview and business interview respondents to describe the spatial pattern of their purchases. For example, they broke purchases down into local and non-local categories. We added further detail by asking which purchases were made in which local communities. This information was used to build the local trade hierarchy. In central Idaho, it is reasonable to assume that Salmon is a dominant trade area. The Tendoy/Leadore, Pahsimeroi, Northfork, and, to a lesser extent, Challis communities are connected to the trade center at Salmon. The Mackay area has sufficient trade with Challis to warrant inclusion in the trade hierarchy. The Stanley Basin, on the other hand, is in Custer County but has less trade in the 2 county area. Its primary economic trade with the rest of the county involves fuel, transportation services, and outfitters and guides.

Respondents also assisted in defining functional economic areas. We disaggregated the 2 counties into 7 functional economic areas closely resembling the Census areas from the 1990 Census of Population ${ }^{1}$. Figure 1 outlines these areas. Census areas are usually defined in rural areas by physical boundaries, political boundaries, or long distances between population centers. The functional areas described by respondents matched very well with the areas used in the Census.

The primary economic sector examined in this paper is agriculture and this is almost exclusively cow/calf ranching. [A small dairy sector around Salmon supplies milk to a small cheese plant there.] Ranch sector data is derived from actual ranch records of 15 enterprises in the 2 county area using the FINPACK program (FINPACK 1993). These 15 enterprises are not a sample. They represent all local ranches willing to provide the very detailed financial records necessary to accurately estimate and evaluate ranch costs and returns using FINPACK. These data are used to construct a detailed ranch sector in the I/O model. According to the 1992 Census of Agriculture 316 ranches in this area are commercially viable and 217 of these operations hold federal grazing permits. A small percentage of land is privately

\footnotetext{
${ }^{1}$ For a technical description of this model and its theoretical basis, see Robison (1997).
}

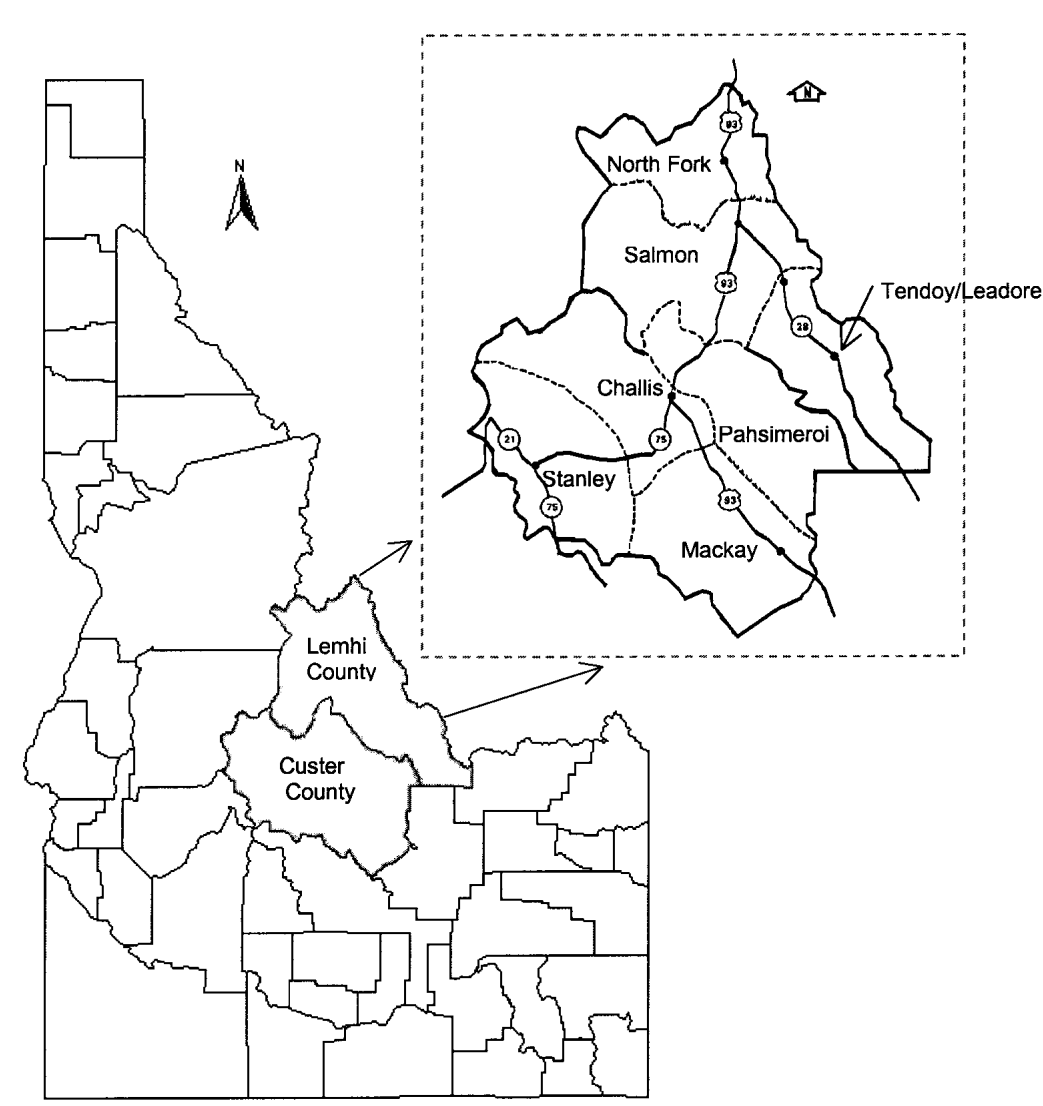

Fig. 1. Central Idaho study area.

owned. Our interviews with local ranchers indicated that, in the short run, few if any private forage options exist for federal permit holders. Ranchers indicated that in the past they had more options than they do currently. When feasible, nearby ranches could be purchased for additional forage and federal AUMs. The current appreciation of ranch land for non-agricultural uses mitigates this strategy. Many respondents had focused their efforts in recent years on upgrading their agronomic and irrigation practices to raise forage yields on their private ground. As an option, this was seen as quickly reaching its technical limits. Purchasing hay or grazing forage outside the area was judged to be unrealistic even in the long run. In the end, we concluded that if federal AUMs are reduced, herd size must be reduced or management intensified on existing private forage while searching for other forage sources and opportunities ${ }^{2}$.

For all other economic sectors, telephone books and local interviews were

\footnotetext{
${ }^{2}$ More intensive management of existing private forage on the part of federal permit holders might make up for some of the AUM reduction, but this factor is almost impossible to estimate and will not be evaluated here..
}

used to identify businesses in each community. We attempted to survey all known local businesses using drop off/pick up and personal interview methods. Respondents supplied information about their employment, sales, where they purchased inputs, and to whom they make sales, by sector. Over 250 businesses were surveyed. The data were used along with employment totals from state and federal sources to build the final model. Finally, we derived unearned income estimates from household income breakdowns for the respective Census areas. These estimates include Social Security payments, dividends, interest, rents, pensions, income support, Medicare, and similar payments. The base year for this model was 1991.

We derived model parameters from interviews with ranchers and businesses in each area. These interviews provided insights into trade patterns, economic exports, income sources, functional economic areas, and reactions to possible changes in the ranch economy. The accuracy and legitimacy of this model rests on these extensive interviews which allowed us to make the fewest assumptions possible. 
Table 1: Custer and Lemhi combined economy, and income summary, 1991.

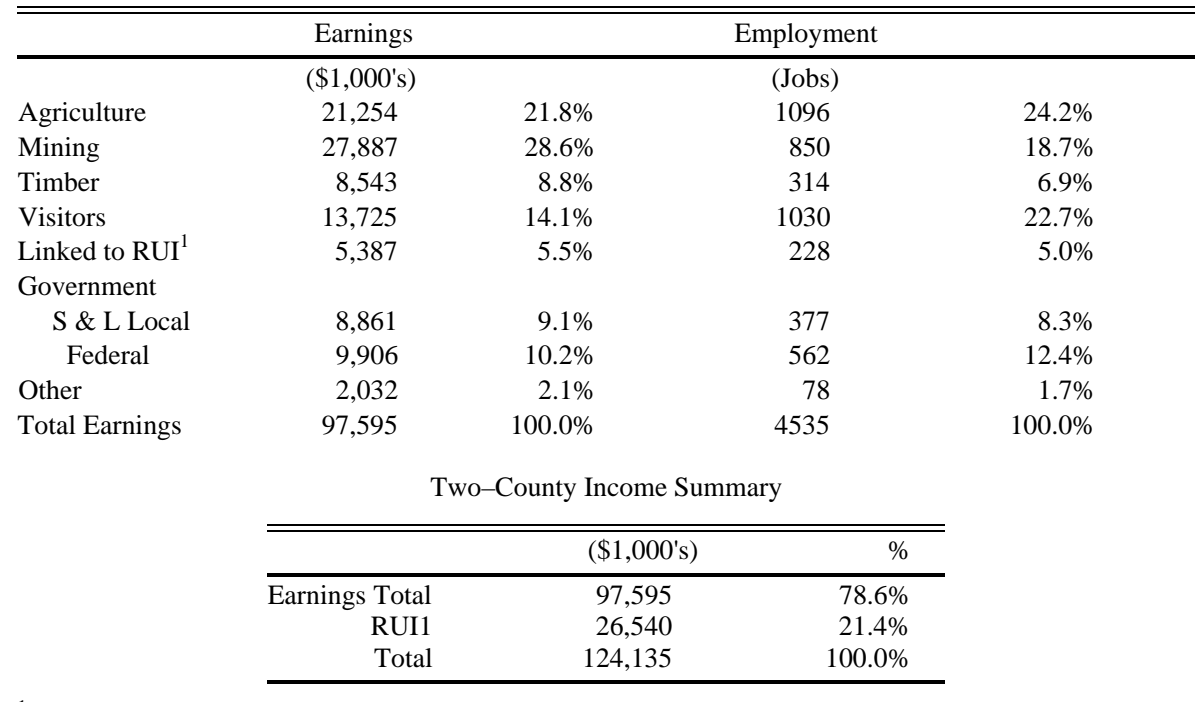

${ }^{1}$ RUI is residents' unearned income. This is all unearned income such as dividends, transfer payments, rents, pensions, income support payments, etc. or income that is unrelated to employment. Earnings and income in this category represent secondary economic activity attributable to the expenditure of residents' unearned income.

\section{Economy of Custer and Lemhi Counties}

Table 1 displays the combined economy and income summary of Custer and Lemhi counties. The economy appears most dependent on agriculture, mining, government and visitors for its earnings and employment. It is important to note that about $21 \%$ of total income comes from residents unearned income (RUI), which in turn generates about $5 \%$ of the total economic activity. The low percent of economic activity related to RUI is derived from the its relation to economic activity. Unlike most sectors, unearned income does not generate direct employment or sales. It is spent as household expenditure, and therefore its impact is limited to a few sectors. Visitors account for about $14 \%$ of earnings, but almost $23 \%$ of the jobs in the 2 county area. Low wages and seasonal employment account for this disparity.

The economies of the 7 communities are presented in Tables 2, 3, and 4. Table 2 presents earnings and Table 3 presents employment, by sector, for each community. Table 4 presents a breakdown of earned and unearned income for each community. Salmon is the county seat of Lemhi County and the trade center for the 2 county region. The government accounts for over $24 \%$ of the earnings due to a BLM District office, a U.S. Forest Service supervisor's office, and state and local government including the school districts. Visitors account for almost a quarter of all jobs, but less than $20 \%$ of the earnings. Northfork is heavily reliant on visitors who account for $43 \%$ of earnings and $63 \%$ of employment. At the same time, over
$50 \%$ of their income is unearned. This situation is not reflected in the local economy because Northfork has few services or retail establishments where local people can spend that income. They must drive to Salmon to buy most goods and services. Wholesale trade and fuel come to North Fork from Salmon to supply goods that are sold there. This is an example of how Salmon serves as a trade center.

The economy of Tendoy/Leadore is clearly dominated by agriculture. The same situation holds for the Pahsimeroi Valley. Over $85 \%$ of earnings in Tendoy/Leadore, and $96 \%$ of the earnings in the Pahsimeroi Valley are derived from ranching. These levels of dependence are extremely high. They also represent extreme departures from the local economy depicted at the 2 county level of aggregation. Note also that almost $44 \%$ of the income in the Pahsimeroi Valley comes from unearned income, income unrelated to earnings. While the earnings of people in the valley are dependent on ranching, almost half of the personal income has nothing to do with ranches. This is partially an artifact of Census aggregation techniques. The Patterson Census area includes a small subdivision on the Salmon River with a largely retired population. This accounts for the high proportion of unearned income. Again, people travel to Salmon or Challis for household purchases so the contribution of this income to their local economy is minimal. A high dependence on mining holds for Challis. Almost $69 \%$ of earnings in that area are derived from mining activities. These payrolls push the percentage of total income from earnings to well over $90 \%$. The economy of the Stanley area is similar, but the dependence instead is on visitors. Finally, the economy of Mackay illustrates another situation. Ranching is extremely important to this area. At the same time, resident's unearned

Table 2. Earnings in 7 communities in Custer and Lemhi Counties, 1991.

\begin{tabular}{|c|c|c|c|c|c|c|c|c|c|c|c|c|c|c|}
\hline & \multicolumn{14}{|c|}{ EARNINGS } \\
\hline & \multicolumn{2}{|c|}{ Salmon } & \multicolumn{2}{|c|}{ Northfork } & \multicolumn{2}{|c|}{ Tendoy-Leadore } & \multicolumn{2}{|c|}{ Pahsimeroi } & \multicolumn{2}{|c|}{ Challis } & \multicolumn{2}{|c|}{ Stanley } & \multicolumn{2}{|c|}{ Mackay } \\
\hline & $(\$ 1000)$ & $(\%)$ & $(\$ 1000)$ & $(\%)$ & $(\$ 1000)$ & $(\%)$ & $(\$ 1000)$ & $(\%)$ & $(\$ 1000)$ & $(\%)$ & $(\$ 1000)$ & $(\%)$ & $(\$ 1000)$ & $(\%)$ \\
\hline Agriculture & 7,126 & 15.8 & 19 & 1.0 & 4,089 & 85.4 & 2823 & 96.5 & 3194 & 10.0 & & & 4003 & 49.8 \\
\hline Mining & 5,660 & 12.5 & & & & & & & 22001 & 68.8 & & & 226 & 2.8 \\
\hline Timber & 7,866 & 17.4 & 75 & 3.9 & & & & & 410 & 1.3 & & & 192 & 2.4 \\
\hline Visitors & 8,886 & 19.7 & 838 & 43.7 & 93 & $1.9 \%$ & 16 & 0.5 & 1587 & 5.0 & 2002 & 72.3 & 303 & 3.8 \\
\hline Linked to ROI & 3,564 & 7.9 & 56 & 2.9 & 53 & $1.1 \%$ & 24 & 0.8 & 729 & 2.3 & 22 & 0.8 & 939 & 11.7 \\
\hline Government & & & & & & & & & & & & & & \\
\hline S \& L Local & 5,495 & 12.2 & 216 & 11.3 & 305 & $6.4 \%$ & 39 & 1.3 & 1644 & 5.1 & 197 & 7.1 & 965 & 12.0 \\
\hline Federal & 5,635 & 12.5 & 709 & 36.9 & 245 & $5.1 \%$ & 24 & 0.8 & 1656 & 5.2 & 497 & 17.9 & 1140 & 14.2 \\
\hline Other & 935 & 2.1 & 6 & 0.3 & 3 & $0.1 \%$ & & & 765 & 2.4 & 50 & 1.8 & 273 & 3.4 \\
\hline Earnings Total & 45,167 & 100.0 & 1,919 & 100.0 & 4,788 & $100.0 \%$ & 2926 & 100.0 & 31987 & 100.0 & 2769 & 100.0 & 8042 & 100.0 \\
\hline
\end{tabular}


Table 3. Employment in 7 communities in Custer and Lemhi Counties, 1991.

\begin{tabular}{|c|c|c|c|c|c|c|c|c|c|c|c|c|c|c|}
\hline & \multicolumn{14}{|c|}{ EARNINGS } \\
\hline & \multicolumn{2}{|c|}{ Salmon } & \multicolumn{2}{|c|}{ Northfork } & \multicolumn{2}{|c|}{ Tendoy-Leadore } & \multicolumn{2}{|c|}{ Pahsimeroi } & \multicolumn{2}{|c|}{ Challis } & \multicolumn{2}{|c|}{ Stanley } & \multicolumn{2}{|c|}{ Mackay } \\
\hline & (Jobs) & $(\%)$ & (Jobs) & $(\%)$ & (Jobs) & $(\%)$ & (Jobs) & $(\%)$ & (Jobs) & $(\%)$ & (Jobs) & $(\%)$ & (Jobs) & $(\%)$ \\
\hline Agriculture & 522 & 22.7 & 5 & 2.8 & 139 & 76.8 & 68 & 84.0 & 157 & 13.1 & & & 205 & 50.7 \\
\hline Timber & 293 & 12.7 & 3 & 1.7 & & & & & 12 & 1.0 & & & 6 & 1.5 \\
\hline Visitors & 572 & 24.8 & 112 & 63.6 & 11 & 6.1 & 7 & 8.6 & 143 & 11.9 & 151 & 79.1 & 34 & 8.4 \\
\hline Linked to ROI & 150 & 6.5 & 4 & 2.3 & 3 & 1.7 & 2 & 2.5 & 32 & 2.7 & 1 & 0.5 & 36 & 8.9 \\
\hline Federal & 309 & 13.4 & 43 & 24.4 & 15 & 8.3 & 2 & 2.5 & 97 & 8.1 & 30 & 15.7 & 66 & 16.3 \\
\hline Other & 42 & 1.8 & 0 & 0.0 & & & & & 24 & 2.0 & 1 & 0.5 & 11 & 2.7 \\
\hline $\begin{array}{l}\text { Employment } \\
\text { Total }\end{array}$ & 2303 & 100.0 & 176 & 100.0 & 181 & 100.0 & 81 & 100.0 & 1199 & 100.0 & 191 & 100.0 & 404 & 100.0 \\
\hline
\end{tabular}

income accounts for about $35 \%$ of the total income and generates enough secondary activity to account for well over $12 \%$ of the earnings. This situation is mostly due to the number of care facilities for the elderly located in Mackay. This draws unearned income in the form of Medicaid, Social Security and pensions into the economy, and a large portion of it is spent in these care facilities. Finally, employees of the Idaho National Engineering Laboratory near Idaho Falls also live in Mackay, accounting for a higher proportion of federal government earnings.

The economic structure of these $7 \mathrm{com}$ munities differs greatly from that of the 2 county aggregate area. Examined at the aggregate level, the economy of this area appears balanced, as does the economy of Salmon, its major trade center. However, extreme departures from this economic structure are the dependence of Tendoy/Leadore and the Pahsimeroi Valley on ranching, the role of mining in the economy of Challis, and the dependence of the Stanley Basin on visitors and tourism. The spatial distribution of economic change in this area is now examined with respect to the ranching sector.

\section{Spatial Distribution of Economic Impacts}

Significant changes to the ranching sector in Custer and Lemhi Counties will clearly affect these 7 communities in different ways. To illustrate this spatial distribution of effects, the input/output model is used to examine 2 scenarios, 1 real and 1 hypothetical. First, we examine the impact of the decline in cattle prices from 1991 to 1996. This serves as an example of the straightforward economic fluctuation of a cattle cycle that affects community economies. Second, we examine a hypothetical reduction in available AUM's on federal range. This serves as an example of a public policy impact that, while hypothetical, is commonly discussed and for which impacts are often estimated.

Reduced Cattle Prices: FINPACK data indicated that total revenue per cow in Custer and Lemhi counties averaged \$508 in 1991. By 1996, this was reduced to $\$ 398$ per cow, or a $21.7 \%$ drop in per cow revenue $^{3}$. We do not expect ranchers to reduce herd size significantly in response to lower prices. Their proprietor's income is reduced and their options include postponing household purchases, or reducing

Table 4. Community income summary for 7 communities in Custer and Lemhi Counties, 1991.

\begin{tabular}{|c|c|c|c|c|c|}
\hline & \multicolumn{2}{|c|}{ Total Earnings } & \multicolumn{2}{|c|}{ RUI } & Total Income \\
\hline & $(\$ 1000)$ & $(\%)$ & $(\$ 1000)$ & $(\%)$ & $(\$ 1000)$ \\
\hline Salmon & 45,167 & 77.3 & 13,298 & 22.7 & 58,465 \\
\hline Northfork & 1,919 & 49.6 & 1,952 & 50.4 & 3,871 \\
\hline Tendoy-Leadore & 4,788 & 85.3 & 826 & 14.7 & 5,614 \\
\hline Pahsimeroi & 2,926 & 56.3 & 2,273 & 43.7 & 5,199 \\
\hline Challis & 31,987 & 90.9 & 3,207 & 9.1 & 35,194 \\
\hline Stanley & 2,769 & 81.9 & 611 & 18.1 & 3,380 \\
\hline Mackay & 8,042 & 64.8 & 4,373 & 35.2 & 12,415 \\
\hline
\end{tabular}

the overall household draw from ranch revenues. We evaluate the reduced income by reducing household consumption. The implication is that herd size and associated costs remain fixed.

The total impact of this reduction in price on the 2 county area and the 7 communities is presented in Table 5. Sales, earnings and employment in the 2 county area each fall about $2 \%$. The distribution of these impacts differs among communities. These differences depend, largely, on primary versus secondary impacts. North Fork has few ranches, and loses little. The Pahsimeroi Valley and Tendoy/Leadore experience different effects. The Pahsimeroi area has few establishments at which ranch households can spend money. Hence, the impacts presented in Table 5 are almost exclusively direct impacts. In terms of sales and earnings, the Mackay economy is hit hardest. Ranches in this area can trade for household goods in Mackay to a greater extent than the more ranch-dependent areas of Pahsimeroi and Tendoy/Leadore. Challis is dominated by mining and this dilutes the overall impact of falling cattle prices on the local economy. In addition, these areas trade with Salmon. Salmon therefore loses sales, earnings and jobs from direct impacts on its ranching sector. It also derives secondary impacts from lost regional trade. However, the overall impact represents a small percentage due to the relative size and diversity of the Salmon economy.

Reduced federal AUMs: The recovery of endangered fish species is an important issue in Custer and Lemhi Counties. Frequently, recovery plans in this area include proposals to reduce grazing near riparian fish habitat on both public and

\footnotetext{
${ }^{3}$ Ranchers might use the futures market to reduce price risk. Our experience, however, is that this excellent option is rarely utilized.
} 
Table 5. Impacts on sales, earnings and employment of drop in cattle prices, 1991 to 1996.

\begin{tabular}{llllrrr}
\hline \hline & \multicolumn{5}{c}{ CHANGE } \\
\cline { 2 - 6 } & Sales & \multicolumn{3}{c}{ Earnings } & \multicolumn{1}{c}{ Employment } \\
\hline & $(\$ 1,000)$ & $(\%)$ & $(\$ 1,000)$ & $($ Jobs $)$ & $(\%)$ \\
CHALLIS & $\$(2,059)$ & -1.8 & $\$(801)$ & -2.5 & $(39)$ & -3.2 \\
Stanley & $\$-$ & 0.0 & $\$-$ & 0.0 & 0 & 0.0 \\
Mackay & $\$(1,225)$ & -4.7 & $\$(246)$ & -3.1 & $(9)$ & -2.3 \\
Pahsimeroi & $\$(45)$ & -0.6 & $\$(18)$ & $-0.6 \%$ & $(1)$ & -1.6 \\
SALMON & $\$(1,837)$ & -1.5 & $\$(745)$ & $-1.6 \%$ & $(33)$ & -1.4 \\
Tendoy-Leadore & $\$(280)$ & -2.5 & $\$(113)$ & -2.3 & $(6)$ & -3.4 \\
North Fork & $\$(1)$ & 0.0 & $\$(0)$ & 0.0 & $(0)$ & 0.0 \\
\hline 2 County Change & $\$(5,447)$ & -1.9 & $\$(1,923)$ & -2.0 & $(89)$ & -2.0 \\
\hline
\end{tabular}

private land. The National Marine Fisheries Service (NMFS) directs recovery efforts in this region for endangered and threatened salmon species. In the delineation of critical habitat, NMFS has suggested that salmon require a $25 \%$ reduction in grazing on federal public lands in this area (Huppert et al. 1992 p.3-82 [citing Haynes et al. 1992]). Other similar proposals to reduce grazing on public lands are common throughout the West. Thus, a

There were 221,286 federal AUMs in Custer and Lemhi Counties in 1991. A $25 \%$ reduction would be a loss of 55,322 AUMs. Data from FINPACK indicate that 13.1 AUMs are required per cow per year (7.9 pasture and 5.2 hay). With the absence of additional private pasture, a loss of 55,322 AUMs results in an estimated 2 county herd reduction of 4,223 cows $(7.4 \%)$. Though not ideal, the most reasonable way to estimate the impact of this

Table 6. Available AUMs, Custer and Lemhi Counties, $1991{ }^{1}$

\begin{tabular}{|c|c|c|c|c|}
\hline & Custer $^{2}$ & Lemhi $^{2}$ & Total & Total \\
\hline Federal AUMs & & & & $(\%)$ \\
\hline USFS & & & 113,716 & 14.7 \\
\hline BLM & & & 107,570 & 14.0 \\
\hline Total Federal AUMs & & & 221,286 & 28.7 \\
\hline Private Pasture AUMs & & & 243,700 & 31.6 \\
\hline Hay AUMs & & & 306,067 & 39.7 \\
\hline Total Feed AUMs & 305,322 & 465,731 & 771,053 & 100.0 \\
\hline
\end{tabular}

${ }^{\mathrm{T}}$ Source: Census of Agriculture (1992).

${ }^{2}$ These AUMs cannot be disaggregated. Ranchers have permits in both counties, the Challis National Forest is in both, and the county line splits the Pahsimeroi Valley.

common policy question is the economic impact such reductions will have on ranchers and rural communities. We model a $25 \%$ reduction in federal grazing and estimate how these impacts would be distributed across the 7 community area.

The available AUMs, both private and federal, are presented in Table 6. Federal AUMs account for over one quarter of all AUMs in the 2 county area. Private pasture accounts for another third of the AUMs. Private land is very limited in these counties and rancher interviews indicate that virtually no additional private pasture is available to compensate for lost federal AUMs in the short run. To estimate the changes in sales, earnings and employment from a $25 \%$ reduction in all federal AUMs in the 2 counties, we estimate the corresponding reduction in the cow herd and the resulting drop in ranch revenue. loss is to distribute the herd reduction proportionally across the seven areas defined in the model. Table 7 presents baseline and reduced cow herd numbers and cow revenues and reflects a $7.4 \%$ reduction in cow herd for each area. The economic impact of this reduction in AUMs and revenues is presented in Table 8. The impact on the overall economy is small, less than $2 \%$ of sales, earnings and employment. Even in those areas highly dependent on ranching, the losses in sales, earnings and employment are roughly in the 5\% to $7 \%$ range. The impact on any single ranch operation of a loss in federal AUMs might be enormous, depending on the flexibility of its nonfederal forage base and other factors. Nonetheless, the overall impact on each community of a $25 \%$ loss of federal grazing ranges from negligible to just over $7 \%$ of economic activity, and the magnitude of the impact is a function of the economic dependence on ranching.

Ideally, the actual AUM reductions would be enumerated by ranch and aggregated in each community area. This would shift the spatial distribution of the cuts to an unknown degree, and result in a different spatial pattern of impacts. However, current discussions about endangered species recovery often include area-wide reductions in grazing and/or forage utilization and cross federal agency jurisdictions and county boundaries. The assumption that all areas will have a proportional AUM reduction is reasonable.

\section{Conclusions}

An input/output model of 7 communities in a 2 county area of central Idaho was described. This model incorporates intercommunity trade and the spatial detail of the local economies. The important result is the degree to which local economies differ from the aggregate 2 county economy. To illustrate this finding, the model was used to evaluate 2 changes in the local ranching industry: the fall in cattle prices from 1991 to 1996 , and a $25 \%$ reduction in available federal grazing AUMs. The spatial distribution of those changes indicated that communities highly dependent

Table 7. Cow herd distribution and revenues before and after $25 \%$ reduction in federal AUMs, 1991.

\begin{tabular}{lcccc}
\hline \hline & $\begin{array}{l}\text { Baseline } \\
\text { Cows }\end{array}$ & $\begin{array}{l}\text { Baseline } \\
\text { Revenues }\end{array}$ & $\begin{array}{c}\text { Proportional Herd } \\
\text { Reduction }\end{array}$ & $\begin{array}{l}\text { Proportional } \\
\text { R e v e n u e }\end{array}$ \\
\hline Mackay & $($ Number $)$ & $(\$ 1,000)$ & $($ Number $)$ & $(\$ 1,000)$ \\
Pahsimeroi & 9,370 & $\$ 4,760$ & 696 & $\$(354)$ \\
Challis & 12,250 & $\$ 6,223$ & 910 & $\$(462)$ \\
Tendoy/Leadore & 14,500 & $\$ 4,318$ & 631 & $\$(321)$ \\
Northfork & 75 & $\$ 7,389$ & 1,080 & $\$(549)$ \\
Salmon & 12,120 & $\$ 6,157$ & 600 & $\$(3)$ \\
Stanley & 0 & $\$-$ & 0 & $\$(457)$ \\
Total & 56,860 & $\$ 28,885$ & 4,223 & $\$-$ \\
\hline
\end{tabular}


Table 8. Impacts on sales, earnings and employment 25\% reduction in federal AUM's, 1991.

\begin{tabular}{lcccrrr}
\hline \hline & \multicolumn{5}{c}{ CHANGE } \\
\hline & Sales & \multicolumn{3}{c}{ Earnings } & \multicolumn{2}{c}{ Employment } \\
\hline & $(\$ 1,000)$ & $(\%)$ & $(\$ 1,000)$ & $(\%)$ & Jobs & $(\%)$ \\
CHALLIS & -517 & $-0.5 \%$ & -194 & $-0.6 \%$ & 10 & $-0.8 \%$ \\
Stanley & 0 & $0.0 \%$ & 0 & $0.0 \%$ & 0 & $0.0 \%$ \\
Mackay & -676 & $-2.6 \%$ & -210 & $-2.6 \%$ & 11 & $-2.7 \%$ \\
Pahsimeroi & -521 & $-7.3 \%$ & -214 & $-7.3 \%$ & 5 & $-6.4 \%$ \\
SALMON & $-1,000$ & $-0.8 \%$ & -389 & $-0.9 \%$ & 31 & $-1.4 \%$ \\
Tendoy-Leadore & -668 & $-6.0 \%$ & -273 & $-5.7 \%$ & 9 & $-4.9 \%$ \\
North Fork & -3 & $-0.1 \%$ & -1 & $-0.1 \%$ & 0 & $-0.2 \%$ \\
2 County Change & $-3,385$ & $-1.2 \%$ & $-1,281$ & $-1.3 \%$ & -66 & $-1.5 \%$ \\
\hline
\end{tabular}

on ranching experience greater overall economic impact than do communities with more diverse economies, or those highly dependent on other industries such as tourism or mining. This situation is not surprising yet it is overlooked in most public policy assessments.

There are larger, more normative policy implications that can be drawn from this research. First, if the impact of eliminating all public land grazing in Custer and Lemhi counties is evaluated at the level of the Idaho state economy, it is probably negligible. The impact of a $25 \%$ reduction in AUMs in those counties appeared to be negligible on the 2-county area as a whole, but did have differential impact on individual communities. Nonetheless, the decision to evaluate the impacts of a public policy at the state level implicitly chooses to ignore local impacts. Moreover, economic changes from different sources can produce cumulative impacts greater for some economies than others. The model presented here forces recognition that local impacts often differ greatly from aggregate impacts. The level of analysis in evaluating grazing policies is a vital issue in the overall public debate.

Second, changing cattle prices affect local economies differently than a reduction in AUMs. We assume that ranchers reduce household consumption when prices fall, but maintain production expenditures, at least in the short run. Reductions in AUMs require overall production in the area to be reduced in addition to contractions in household consumption. In the long run, a reduction in AUMs creates a demand for additional forage in an area where private land is both scarce and high priced. Thus, management flexibility greatly determines how well ranchers can respond to change. Over time, ranchers respond to fewer AUMs via management options and this produces a proportionally larger impact on local economies than a short-term price reduction. To illustrate this, a $21.7 \%$ drop in prices results in a $21.7 \%$ reduction in revenues, and reduces economic activity by about $2 \%$ [Table 5]. The loss of $25 \%$ of AUMs reduces herd size and associated revenues by about $7.4 \%$ [Table 7], reducing economic activity by about $1-1.5 \%$ [Table 8]. The overall impact of the AUM loss is proportionally greater than the impact of the price drop.

These findings have implications for modeling efforts addressing public land policy in general. As we show, the structure of local economies can be very different. Many of the policy options frequently offered to ease the economic transition of rural communities to less dependence on traditional industries fail to account for these very different local economies. Some argue that growth in the services and recreation sectors and in single proprietorships not dependent on local resources (so-called "lone eagles") is the best future for the west (Power 1996, Rasker 1993). These sectors can be very important to rural communities, particularly recreation. However, their economic impact depends on the structure of the local economy. In this study, areas like Challis would benefit differently from an expanded recreation sector than would the Tendoy/Leadore area. A basic economic infrastructure exists to capture recreation dollars in Challis, but is almost negligible in Tendoy/Leadore. Moreover, the relationship between earnings and employment in this model reflects the low pay and seasonal nature of many jobs in the service and recreation sectors. These issues are often ignored when the economic future of rural communities in the west is discussed.

\section{Literature Cited}

Anderson, D. P., J. W. Richardson, and R. D. Knudson. 1993. Alternative grazing fee formulation impacts on representative public land ranches. J. Range Manage. 46(6):548-554.
Bartlett, E.T., R.G. Taylor, and J.R. McKean. 1979. Impacts of Federal Grazing on the Economy of Colorado. Colo. State Univ., Dept. of Range Sci., Fort Collins, Colo.

Cook, C.W., R.G. Taylor, and E.T. Bartlett. 1980. Impacts of Federal Range Forage on Ranches and Regional Economics of Colorado. Colo. State Univ. Exp. Sta. Bull. 576S. July.

FINPACK User's Guide. 1993. Center for Farm Financial Management, Univ. of Minn.

Lacey, J. R. and J. B. Johnson. 1990 Livestock Grazing on Federal Lands: A Boon to Montana's Economy. West. Wildl. 16(2):23-27.

LaFrance, J. T. and M. J. Watts. 1995. Public grazing in the west and Rangeland Reform '94. Amer. J. Agr. Econ. 77(3):447-461.

Lambert, D. K. 1987. Ranch values and the federal grazing fee. J. Range Manage. 40(5):397-400.

Haynes, R. W., D. T. Hormaechea and A. Bolon. 1992. The economic impact on the forest sector of critical habitat delineation for Columbia River basin salmon. Draft working paper, Pacific Northwest Res. Sta., U.S.D.A., U.S.F.S., Portland, Ore., May.

Huppert, D. D., D. L. Fluharty, and E. S. Kenney. 1992. Economic effects of management measures within the range of potential critical habitat for Snake River endangered and threatened salmon species. School of Marine Affairs, HF-05, Univ. of Wash., Seattle, Wash. Submitted to Nat. Marine Fisheries Service, June.

Power, T. 1996. Lost Landscapes and Failed Economies. Washington D.C: Island Press.

Rasker, R. 1993. Rural development, conservation, and public policy in the greater Yellowstone ecosystem. Soc. Natur. Resources. 6(2):109-126.

Robison, M. H. 1997. Community input-output models for rural area analysis with an example from central Idaho. Ann. of Reg. Sci. 31(3):325-352.

Rowan, R.C. and White, L. D. 1994. Regional differences among Texas rangeland operators. J. Range Manage. 47(5):338-343.

Torell, L. A. and J. P. Doll. 1991. Public land policy and the value of grazing permits. West. J. Agr. Econ. 16(1):174-184.

Torell, L. A. and T.W. Drummond. 1997. The Economic impacts of increased grazing fees on Gila National Forest grazing permittees. J. Range Manage. 50(1):94-105. 


\title{
Supplementation of yearling steers grazing Northern Great Plains rangelands
}

\author{
JAMES F. KARN
}

Author is a research animal scientist, USDA-ARS, Northern Great Plains Research Laboratory, P. O. Box 459, Mandan, N.D 58554.

\begin{abstract}
Growing yearling steers on summer rangelands as part of a cow-calf-yearling operation would allow producers to maximize forage utilization, and selling yearling steers when forage was in short supply would minimize potential genetic losses in the cow herd. A series of summer supplementation and intake studies were conducted from 1988-1992 to determine if weight gains of grazing yearling steers could be increased by supplemental energy (ground barley), phosphorus (P), or crude protein. Studies were conducted at 2 locations on pastures of approximately 51 ha each, which contained quite different mixtures of forage species. Forage $P$, crude protein and IVDOM levels were monitored throughout the grazing season. Supplementation results varied among years and between locations. There were significant $(P<$ 0.14) location by treatment interactions in 1989 and 1990 because steers at the WEST location tended to respond more to supplementation than steers at the EAST location, but EAST location steers had the highest rates of gain. Providing supplements at gradually increasing rates produced results comparable to supplementing at a constant rate all summer. Supplemental crude protein showed no significant benefit, but crude protein levels in pasture forage were generally above steer requirements. Weight gains averaged over all 5 years were greater $(P<0.05)$ for steers supplemented with barley or barley and $P$, compared to unsupplemented control steers. The response to supplementation should be beneficial most years, but results may vary with the quantity and quality of available forage.
\end{abstract}

Key Words: Dry matter intake, forage crude protein, forage phosphorus, ground barley

Grazing yearling steers on Northern Great Plains native rangelands could improve the economic viability of a ranching operation. During dry years, steers could easily be sold without jeopardizing the investment in a high quality cow herd. When forage production was abundant, steers could be used to harvest the extra forage without increasing cow numbers. Enhancing the weight gains of grazing steers through appropriate supplementation may make this option even more viable. Chemical composi-

This article is a contribution from USDA, Agricultural Research Service, Mandan, North Dakota. The author wishes to thank Mr. Richard Huppler for diligently caring for the animals and for collecting and processing research samples and Dr. Gary V. Richardson for advice and assistance with statistical procedures.

U.S. Department of Agriculture, Agriculture Research Service, Northern Plains Area, is an equal opportunity/affirmative action employer, and all agency services are available without discrimination.

Mention of a trade name is solely to identify materials used and does not constitute endorsement by the U. S. Department of Agriculture.

Manuscript accepted 28 Jan 1999.

\section{Resumen}

El desarrollar novillos en pastizales de verano como parte del sistema vaca-becerro-novillo podría permitir a los productores maximizar la utilización de forraje y vender los novillos cuando el forraje es escaso y minimizar las perdidas genéticas potenciales en el hato de vacas. De 1988 a 1992 se condujo una serie de estudios de consumo y suplementación de verano para determinar si las ganancias de peso de novillos en apacentamiento podrían ser incrementadas por la suplementación energética (cebada molida), de fósoforo (P) o de proteína cruda (PC). Los estudios se condujeron en 2 localidades en potreros de aproximadamente 51 ha cada uno, los cuales contenían mezclas de especies forrajeras muy diferentes. El contenido de fósforo, proteína cruda del forraje y su digestibilidad in vitro de la materia orgánica se monitorearon a través de la estación de apacentamiento. Los resultados de la suplementación variaron entre años y entre localidades. En 1989 y 1990, hubo interacciones significativas $(P<0.14)$ entre tratamiento y localidad, esto debido a que los novillos de la localidad OESTE tendieron a responder mejor a la suplementación que los novillos de la localidad ESTE, pero los novillos de la localidad ESTE tuvieron mayores tasas de ganancia de peso. El proveer el suplemento a tasas graduales de incremento produjeron resultados comparables que suplementar a una tasa constante durante todo el verano. La proteína cruda suplementaria no mostró beneficios significativos, pero los niveles de proteína cruda en el forraje del potreo generalmente fueron superiores a los requerimientos de los novillos. Las ganancias de peso, promediadas en los 5 años, fueron mayores ( $P$ < 0.05) para los novillos suplementados con cebada o con cebada y fósforo que las ganancias obtenidas por los novillos sin suplemento (control). La respuesta a la suplemetación debe ser benéfica en la mayoría de los años, pero los resultados pueden variar con la cantidad y calidad del forraje disponible.

tion data for Northern Great Plains native forages reported by Karn (1992) suggest that phosphorus (P), crude protein, and energy are probably the nutrients which most limit animal productivity, especially during the latter part of the grazing season.

Although the recommended (NRC 1996) range of $P$ for yearling steers is $0.15-0.24 \%$, depending on steer weight and rate of gain, Call et al. (1978) reported that $\mathrm{P}$ supplementation was not beneficial to replacement heifers receiving a basal diet containing $0.14 \%$ P (as fed basis). However, Echevarria et al. (1987) reported that steers grazing grasses containing 0.16 to $0.19 \% \mathrm{P}$ had improved weight gains when supplemented with dicalcium phosphate. Winter (1988) reported an immediate weight gain response in $\mathrm{P}$ supplemented steers grazing grasses containing 0.1 to $0.15 \%$ $\mathrm{P}$ during the wet but not the dry season. 
Table 1. Precipitation and mean monthly ambient air temperatures between April and September for 1988, 1989, 1990, 1991, and 1992, and the 80year average.

\begin{tabular}{|c|c|c|c|c|c|c|c|c|c|c|c|c|}
\hline & \multicolumn{2}{|c|}{1988} & \multicolumn{2}{|c|}{1989} & \multicolumn{2}{|c|}{1990} & \multicolumn{2}{|c|}{1991} & \multicolumn{2}{|c|}{1992} & \multicolumn{2}{|c|}{ 80-year average } \\
\hline & Temp. & Precip. & Temp. & Precip. & Temp. & Precip. & Temp. & Precip. & Temp. & Precip. & Temp. & Precip. \\
\hline & $\left({ }^{\circ} \mathrm{C}\right)$ & $(\mathrm{mm})$ & $\left({ }^{\circ} \mathrm{C}\right)$ & $(\mathrm{mm})$ & $\left({ }^{\circ} \mathrm{C}\right)$ & $(\mathrm{mm})$ & $\left({ }^{\circ} \mathrm{C}\right)$ & $(\mathrm{mm})$ & $\left({ }^{\circ} \mathrm{C}\right)$ & $(\mathrm{mm})$ & $\left({ }^{\circ} \mathrm{C}\right)$ & $(\mathrm{mm})$ \\
\hline Apr. & 6.7 & 2.5 & 6.6 & 54.1 & 6.5 & 3.3 & 8.0 & 47.5 & 4.9 & 7.9 & 5.3 & 39.1 \\
\hline June & 24.3 & 23.1 & 17.3 & 19.6 & 18.6 & 132.8 & 19.6 & 97.8 & 17.1 & 110.2 & 17.8 & 89.2 \\
\hline July & 22.7 & 38.6 & 24.0 & 31.0 & 21.0 & 25.6 & 21.8 & 21.1 & 17.0 & 77.0 & 21.2 & 56.9 \\
\hline Aug. & 20.8 & 82.0 & 20.9 & 32.8 & 21.9 & 48.5 & 22.9 & 22.3 & 17.6 & 36.6 & 20.4 & 50.0 \\
\hline Sep. & 13.3 & 15.7 & 14.3 & 27.2 & 16.4 & 41.1 & 14.9 & 59.4 & 13.3 & 26.7 & 14.0 & 39.6 \\
\hline
\end{tabular}

Denham (1975) found that supplementing steers grazing annual rye with $0.9 \mathrm{~kg}$ of corn daily over a 63-day period increased daily gains by $0.33 \mathrm{~kg}$. Vadiveloo and Holmes (1979) reported that when herbage supply was limiting, weight gains of grazing steers were significantly increased by supplemental energy but not by protein, however, when herbage was adequate supplementation was not beneficial. Reyneke (1976) reported that strategic supplementation of grazing steers produced significant results 2 out of 3 years, with protein concentrate producing the greatest response and maize meal producing the least. Lusby et al.(1981) also reported that in the late summer and fall, steer weight gains were efficiently increased by supplemental protein but not by energy. The inconsistency of previous results, plus a lack of research on supplements for grazing steers in the Northern Great Plains, suggested a need for further research. Thus, the objective of the current research was to determine the effect of crude protein and energy supplementation, at either constant or variable rates, and $\mathrm{P}$ supplementation at a constant rate, on the performance of yearling steers summer grazing on native rangelands.

\section{Materials and Methods}

\section{Study Site}

Two pastures located near Mandan, N.D., were used in these studies and will be referred to as EAST and WEST. Each pasture contained approximately 51 ha and was primarily native rangeland, but the topography and species represented in each pasture was quite different. The WEST pasture was relatively flat and contained primarily western wheatgrass (Pascopyrum smithii (Rydb.) A. Love), needleandthread (Stipa comata Trin. and Rupr.), green needlegrass ( $S$. viridula Trin.), blue grama (Bouteloua gracilis (H.B.K.) Griffiths), prairie junegrass [Koeleria cristata (Lam.) Beauv.], and upland sedges (Carex spp.). The EAST pasture was more rolling and contained a greater diversity of species, including the same species as the WEST pasture plus lead plant (Amorpha canescens Pursh), western snowberry (Symphoricarpos occidentalis Hook), buffaloberry [Sherpherdia argentea (Pursh) Nutt.], and the introduced cool-season grass species crested wheatgrass [Agropyron desertorum (Fisch. ex Link) Schultes] and smooth broomegrass (Bromus inermis Leyss).

Daily precipitation and ambient minimum and maximum air temperatures were recorded at a weather station located about $3.2 \mathrm{~km}$ north of the study site. Monthly precipitation totals and mean monthly temperatures (minimum and maximum) were calculated and compared to historic values (Table 1).

\section{Supplementation}

A series of supplementation trials were conducted with yearling steers (Bos taurus) grazing during the summer on the previously described pastures. Supplementation trials were conducted at the WEST pasture in 1988 and 1989, while both supplementation and intake trials were conducted at the EAST pasture. In 1990, 1991, and 1992 replicated studies were conducted at both locations. Trials were conducted from 26 May to 4 October 1988 (131 days); 30 May to 6 October 1989 (129 days); 5 June to 12 October 1990 (129 days); 31 May to 11 October 1991 (133 days); and 28 May to 8 October 1992 (133 days). Straight bred Hereford steers were used in all years, but in 1988, Hereford-Simmental crossbred steers also were used to compare the effect of breed type on supplementation response. Initial and final steer weights, as well as weights taken at 21-day intervals, were obtained following an overnight stand without feed or water.

\section{8}

Supplementation treatments in 1988 were no supplement (control), ground barley, and ground barley plus $\mathrm{P}$. There were 6 steers per treatment and 2 breed types for a total of 36 steers at the WEST location and 5 Hereford steers per treatment for a total of 15 steers at the EAST location. Supplement composition and amounts fed daily (as-fed basis), 6 days per week, are shown in Table 2.

\section{9}

The control, barley, and barley $+\mathrm{P}$ treatments were also used in 1989 , but there

Table 2. Barley (B), barley-phosphorus (BP), barley-soybean meal (BS), and barley-soybean mealphosphorus (BSP), supplement ingredients, and the grams (as-fed basis) fed per steer per day during the summers of 1988, 1989, 1990, 1991, and 1992.

\begin{tabular}{|c|c|c|c|c|c|c|c|c|}
\hline \multirow{2}{*}{$\begin{array}{l}\text { Year/ } \\
\text { Month }\end{array}$} & \multirow{2}{*}{$\frac{\mathrm{B}}{\text { Barley }}$} & \multicolumn{2}{|c|}{$\mathrm{BP}$} & \multicolumn{2}{|c|}{ BS } & \multicolumn{3}{|c|}{ BSP } \\
\hline & & Barley & $\overline{\mathrm{MSP}^{2}}$ & Barley & $\mathrm{SBM}^{2}$ & Barley & SBM & MSP \\
\hline $1988^{3}$ & 908 & 908 & 23 & -- & -- & -- & -- & -- \\
\hline $1989^{3}$ & 908 & 908 & 23 & -- & -- & -- & -- & -- \\
\hline $1990^{3}$ & 908 & 908 & 23 & 454 & 454 & 454 & 454 & 23 \\
\hline $1991-1992^{4}$ & & & & & & & & \\
\hline Jun. & 454 & 454 & 23 & -- & -- & 363 & 91 & 23 \\
\hline Jul. & 681 & 681 & 23 & -- & -- & 454 & 227 & 23 \\
\hline Aug. & 908 & 908 & 23 & -- & -- & 454 & 454 & 23 \\
\hline Sep. & 1135 & 1135 & 23 & -- & -- & 681 & 454 & 23 \\
\hline Oct. & 1498 & 1498 & 23 & -- & -- & 817 & 681 & 23 \\
\hline Mean & 908 & 908 & 23 & -- & -- & 539 & 369 & 23 \\
\hline
\end{tabular}

${ }^{\mathrm{T}}$ Steers were fed 6 days per week.

${ }^{2} \mathrm{MSP}=$ monosodium phosphate; SBM=soybean meal

${ }^{3}$ Steers supplemented at a constant rate all summer.

${ }^{4}$ In 1991 and 1992, steers were supplemented at a variable rate; there were 24 feeding days at the June, July, August, and September rates respectively, and 18 feeding days at the October rate. 
Table 3. Phosphorus, crude protein and metabolizable energy provided daily, 6 days per week in supplements fed to yearling steers grazing native rangelands in $1988,1989,1990,1991$, and 1992. ${ }^{1,2}$

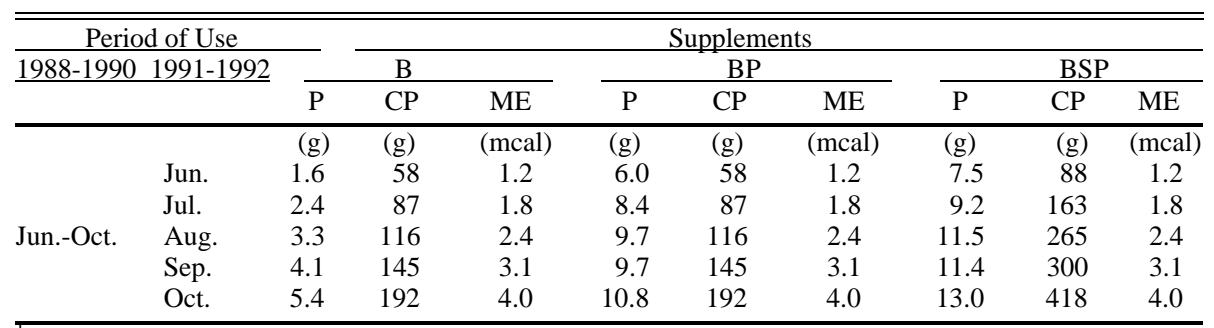

$\mathrm{B}=$ ground barley; $\mathrm{BP}=$ ground barley and monosodium phosphate; $\mathrm{BSP}=$ ground barley, monosodium phosphate and soybean meal.

${ }^{2}$ The barley-soybean meal supplement used in 1990 had the same crude protein and metabolizable energy content with 6 grams less phosphorus than the August BSP supplement.

were 7 steers per treatment for a total of 21 steers at the WEST location and 6 steers per treatment for a total of 18 steers at the EAST location.

\section{0}

In 1990, in addition to the control, barley, and barley + P treatments, supplements containing a 50-50 mixture of barley and soybean meal and a 50-50 mixture of barley and soybean meal plus $\mathrm{P}$ were also used. Supplements were isocaloric. There were 5 steers per treatment per location for a total of 50 steers.

\section{1 and 1992}

In 1991 and 1992, only the control, barley, barley $+\mathrm{P}$, and barley + soybean $+\mathrm{P}$ treatments were used, and there were 7 steers per treatment per location for a total of 56 steers used each year. Supplements in 1991 and 1992 were fed at gradually increasing rates from June through October in contrast to 1988,1989 , and 1990 when supplements were fed at a constant rate throughout the summer (Table 2). Supplement levels were increased to coincide with the usual decline in forage quality. Levels of $\mathrm{P}$, crude protein, and metabolizable energy supplied by supplements are shown in Table 3.

\section{Supplementation Procedure for all Years}

In all treatments where $\mathrm{P}$ was supplemented, monosodium phosphate was used as the $\mathrm{P}$ source and it was fed at a rate of $6 \mathrm{~g} \mathrm{P}$ steer $^{-1}$ day $^{-1}$. Steers at each location were maintained together at all times except when corralled each morning between 0600 and 0800 hours, 6 days per week, separated into treatment groups and bunk fed their respective supplements by group. Non-supplemented steers were also corralled while supplemented steers were being fed. Trace mineralized salt contain- ing $96-98.5 \%$ salt, $0.35 \%$ zinc, $0.34 \%$ iron, $0.20 \%$ manganese, $0.033 \%$ copper, $0.007 \%$ iodine, and $0.005 \%$ cobalt (Akzo Salt, Inc., Clarks Summit, Penn.) was available at all times.

\section{Intake}

Five intake trials were conducted at the EAST location each summer during 1988 and 1989, and 2 intake trials were conducted at each location during the summers of 1991 and 1992. Intake trials were initiated on 23 June, 14 July, 4 and 25 August and 15 September 1988; and 22 June, 13 July, 3 and 24 August and 14 September 1989. In 1991, trials were initiated on 26 June (early summer) and 28 August (late summer), and in 1992, trials were initiated on 15 July (early summer) and 9 September (late summer). Dry matter intake was estimated for unsupplemented (control) steers, steers fed ground barley, and steers fed ground barley $+\mathrm{P}$ in 1988 and 1989 and for control and barley + soybean + P treatment steers in 1991 and 1992. All steers at the EAST location were used in the 1988 and 1989 intake trials, and all steers on the control and barley + soybean $+\mathrm{P}$ treatments at both locations were used in 1991 and 1992 trials.

Fecal output was estimated using chromium as an external indicator. In 1988 and 1989, gelatin capsules containing chromic oxide were administered daily. In 1991 and 1992, chromium was delivered with an intra-ruminal continuous release device ${ }^{1}$ (Adams et al. 1991) administered at the beginning of each trial. Five daily fecal collections were made following a 10-day adjustment period to insure that chromium had reached a consistent concentration in the digestive tract. During the first 2 trials in 1988 , steers were dosed with $10 \mathrm{~g}$

${ }^{1}$ Captec chrome manufactured by Captec PTY, LTD., Laverton, Victoria, Australia. chromic oxide per steer daily, which was midway between levels used by Rittenhouse et al. (1970) and Adams et al. (1986). From the third trial on and for all of the 1989 trials, chromic oxide was given at the rate of $8 \mathrm{~g}$ per steer daily (Rittenhouse et al. 1970). The continuous release device used in 1991 had mean release rates of either 1.57 or $1.74 \mathrm{~g}$ chromic oxide day ${ }^{-1}$ and the continuous release device used in 1992 had mean release rates of $1.48 \mathrm{~g}$ chromic oxide day ${ }^{-1}$ according to the manufacturer. Two unsupplemented steers in 1988 and 1989 and 3 unsupplemented steers in 1992 were fitted with fecal collection bags and dosed with chromic oxide during each trial in 1988 and 1989 or given a continuous release device at the beginning of each trial in 1992 to measure total fecal output for chromium recovery calculations. Daily fecal collections during each trial were composited on an equal wet volume basis across days for each steer, so that a single sample per steer per trial was saved for analysis.

Indigestible neutral detergent fiber (INDF) was determined on extrusa, supplement, and fecal samples as suggested by Ellis et al. (1984) and was used instead of lignin to calculate forage intake according to procedures outlined by Rittenhouse et al. (1970). Because supplements and forages are likely to have different digestibilities, the amount of fecal dry matter originating from supplements must be partitioned from the total fecal dry matter before forage intake can be calculated. Since the amount of supplement dry matter is known, the amount of an internal indicator such as lignin or indigestible NDF, which is presumed to be indigestible can be determined for supplements and feces. Then the amount of indicator originating from the supplement can be subtracted from the total amount of indicator in the feces. The remaining quantity of the indicator is presumed to originate from ingested forage. Forage intake can then be determined by dividing the weight of indicator in the feces originating from the forage by the concentration of the indicator in the forage. Once forage dry matter intake is determined, total dry matter intake is calculated by combining forage and supplement intake values.

\section{Sampling Procedures}

Forage samples were collected each year at both locations with 3 mature esophageally fistulated steers at approximately 3 week intervals throughout the grazing season. Fistulated steers were penned off feed overnight before each sampling date to ensure that they would 
Table 4. Mean $( \pm$ SD) monthly phosphorus and crude protein concentrations in Northern Great Plains native pastures being grazed by yearling steers receiving energy, phosphorus and crude protein supplements in 1988, 1989, 1990, 1991, and 1992. ${ }^{1,2,3}$

\begin{tabular}{|c|c|c|c|c|c|c|c|c|c|c|c|}
\hline \multirow[b]{2}{*}{ Year } & \multirow[b]{2}{*}{ Location } & \multicolumn{5}{|c|}{ Phosphorus } & \multicolumn{5}{|c|}{ Crude protein } \\
\hline & & Jun. & Jul. & Aug. & Sep. & $\begin{array}{c}\text { Location } \\
\text { mean }\end{array}$ & Jun. & Jul. & Aug. & Sep. & $\begin{array}{c}\text { Location } \\
\text { mean }\end{array}$ \\
\hline & & & & & & & & & $\%$ of D.M. & & \\
\hline 1988 & W & $0.174 \pm 0.023$ & $0.178 \pm 0.020$ & $0.166 \pm 0.018$ & $0.144 \pm 0.012$ & $0.167 \pm 0.021$ & $8.6 \pm 0.7$ & $9.1 \pm 0.5$ & $11.1 \pm .0 .6$ & $8.2 \pm 0.1$ & $9.4 \pm 1.4$ \\
\hline \multirow[t]{2}{*}{1989} & $\mathrm{E}$ & $0.229 \pm 0.004$ & $0.183 \pm 0.009$ & $0.140 \pm 0.024$ & $0.176 \pm 0.008$ & $0.180 \pm 0.029$ & $13.7 \pm 0.5$ & $9.9 \pm 0.5$ & $8.7 \pm 1.2$ & $11.3 \pm 0.1$ & $10.9 \pm 1.8$ \\
\hline & $\mathrm{W}$ & $0.195 \pm 0.023$ & $0.133 \pm 0.007$ & $0.151 \pm 0.009$ & $0.234 \pm 0.003$ & $0.178 \pm 0.038$ & $11.4 \pm 1.8$ & $11.6 \pm 0.5$ & $9.0 \pm 0.8$ & $12.1 \pm 0.7$ & $10.8 \pm 1.7$ \\
\hline 1990 & $\mathrm{E}$ & $0.238 \pm 0.014$ & $0.262 \pm 0.029$ & $0.190 \pm 0.008$ & $0.194 \pm 0.019$ & $0.224 \pm 0.038$ & $13.5 \pm 0.4$ & $13.1 \pm 2.5$ & $8.5 \pm 0.6$ & $10.6 \pm 0.9$ & $11.6 \pm 2.4$ \\
\hline 1991 & W & $0.209 \pm 0.029$ & $0.175 \pm 0.017$ & $0.135 \pm 0.009$ & $0.129 \pm 0.020$ & $0.162 \pm 0.038$ & $13.8 \pm 1.6$ & $9.3 \pm 0.4$ & $6.0 \pm 0.3$ & $6.2 \pm 0.9$ & $8.8 \pm 3.3$ \\
\hline \multirow[t]{2}{*}{1992} & $\mathrm{E}$ & $0.166 \pm 0.011$ & $0.189 \pm 0.018$ & $0.140 \pm 0.016$ & $0.122 \pm 0.001$ & $0.159 \pm 0.029$ & $12.5 \pm 0.8$ & $14.4 \pm 1.1$ & $10.8 \pm 1.4$ & $9.9 \pm 0.2$ & $12.2 \pm 2.0$ \\
\hline & W & $0.122 \pm 0.004$ & $0.138 \pm 0.011$ & $0.112 \pm 0.006$ & $0.091 \pm 0.013$ & $0.119 \pm 0.021$ & $13.3 \pm 0.6$ & $12.3 \pm 2.0$ & $9.0 \pm 0.8$ & $7.5 \pm 0.7$ & $10.7 \pm 0.3$ \\
\hline
\end{tabular}

Samples were collected with unsupplemented esophageal fistula steers in 1988-1991 and by hand clipping in 1992.

${ }^{2}$ The EAST (E) location pasture was used for the intake trials in 1988 and 1989 and as a replicate pasture in 1990, 1991 , and 1992

${ }^{3}$ Monthly values are means of 3 to 6 sample collections.

graze the following morning. Grazing selectivity did not appear to be affected by this method. Individual animal collections were mixed, subsampled, freeze dried and analyzed for nitrogen (N), in vitro digestible organic matter (IVDOM) and INDF. Extrusa subsamples for $\mathrm{P}$ analysis were squeezed to remove saliva (Hoehne et al. 1967) and oven dried at $50^{\circ} \mathrm{C}$. In 1992 , because no squeezed extrusa samples were collected, samples were hand clipped to simulate grazing (Karn and Hofmann 1990) and analyzed for $\mathrm{N}$ and $\mathrm{P}$. Hand clipped samples were freeze dried before grinding. All forage samples were ground to pass a $1 \mathrm{~mm}$ screen before chemical analyses.

\section{Chemical Analyses}

Nitrogen and $\mathrm{P}$ in forage were determined with a Quikchem 8000 continuous flow autoanalyzer (Lachat Instruments, Milwaukee, Wisc. 53218). Fecal samples from the intake trials were prepared for chromium analysis according to Williams et al. (1962), and chromium was determined with a Perkin Elmer P II inductive coupled plasma optical emission spectrophotometer (Perkin Elmer, Norwalk, Conn.). In vitro digestible organic matter was determined by the Tilley and Terry (1963) procedure as modified by Moore and Mott (1974). Indigestible neutral detergent fiber was determined by following a 6-day in vitro fermentation (Ellis et al. 1984) with neutral detergent fiber analysis of the fermentation residue (Goering and Van Soest 1970).

\section{Statistical Analyses}

Steer weight gain data were analyzed over locations by year using a randomized design, with locations considered as replications and treatment groups considered the experimental unit. Treatment and location were tested with the treatment $\mathrm{x}$ location interaction term. Although crossbred and Hereford steers responded similarly to supplements, only Hereford steer data were included in the analysis over both locations in 1988 so that data would be more nearly balanced. Treatment means for individual years were separated by the Student-Newman-Keuls' test. In a second analysis, treatments in common over the 5 years were analyzed as a mixed model according to a treatment by location factorial in a randomized block design. Least squares means were separated by a Tukeys test. Constant versus increasing supplementation levels were considered as nested within treatments (Milliken and Johnson 1984).

Intake data in 1988, 1989, 1991, and 1992 were analyzed as a completely randomized design, with the steer within treatment term used to test treatment in the 1988 and 1989 trials, and the steer within treatment by location term used to test treatment, location, and treatment x location in 1991 and 1992 trials. Least squares means were calculated for intake data using SAS (1985) GLM procedures in 1991 and 1992. Treatments were considered different at the $5 \%$ probability level unless otherwise stated.

\section{Results and Discussion}

According to the NRC (1996), the crude protein requirement of growing steers, of the weight used in these studies, ranges between 8 and $12 \%$ of the diet dry matter depending on steer weight and daily gains. Crude protein at both locations was generally within this range throughout the summer, except for 1991 (Table 4) which prob- ably explains the lack of a significant response to supplemental protein in 1990 and 1992. Forage P levels during August and September at both locations were generally at or below the NRC (1996) recommended range of $0.15-0.24 \% \mathrm{P}$ for yearling steers. Forage growth and hence forage quality, especially for cool-season grasses, is very closely related to seasonal precipitation patterns. In 1988, August precipitation (Table 1) was above normal which facilitated forage regrowth and resulted in unusually high August forage crude protein, $\mathrm{P}$ and IVDOM levels, especially at the EAST location (Tables 4 and 5).

Steer weight gain data were analyzed by year as well as over all years because there were apparent differences in treatment responses among years and between locations which reflected differences in topography and forage types between locations.

\section{8}

In 1988 crossbred and straight-bred Herefords at the WEST location responded similarly to barley and barley $+\mathrm{P}$ treatments (data not shown), but only Hereford steer data were analyzed with weight gain data from the EAST location (Table 6) so that data would be more nearly balanced. There were no significant treatment differences; however, there was a location effect with steers at the EAST location having higher daily gains than steers at the WEST location (1.07 vs. $0.72 \mathrm{~kg}$; P < 0.05). This was thought to be due to forage quality differences between pastures since $\mathrm{P}$, crude protein, and IVDOM were all higher in forage from the EAST pasture (Tables 4 and 5).

\section{9}

In 1989, daily gains (Table 6) were higher $(\mathrm{P}<0.15)$ for steers receiving the 
Table 5. Mean ( \pm SD) monthly IVDOM of extrusa samples from Northern Great Plains native pastures being grazed by yearling steers receiving energy, phosphorus and crude protein supplements in 1988, 1989, 1990, 1991, and 1992.

\begin{tabular}{lcccccc}
\hline \hline Year & Location & Jun. & Jul. & Aug. & Sep. & Loc. Mean \\
\hline \multirow{2}{*}{1988} & E & $70.4 \pm 1.0$ & $63.3 \pm 2.0$ & $67.0 \pm 1.9$ & $61.8 \pm 0.4$ & $64.6 \pm 3.5$ \\
& W & $59.2 \pm 1.8$ & $58.0 \pm 1.5$ & $59.9 \pm 3.0$ & $58.4 \pm 1.1$ & $59.1 \pm 2.1$ \\
1989 & E & $74.3 \pm 0.5$ & $67.4 \pm 2.1$ & $63.8 \pm 1.0$ & $60.7 \pm 1.2$ & $65.7 \pm 5.0$ \\
& W & $70.5 \pm 4.1$ & $65.1 \pm 4.1$ & $62.8 \pm 0.8$ & $56.4 \pm 1.6$ & $64.1 \pm 6.4$ \\
1990 & E & $69.5 \pm 0.8$ & $65.8 \pm 3.7$ & $61.8 \pm 1.1$ & $57.2 \pm 3.1$ & $62.9 \pm 5.4$ \\
& W & $63.6 \pm 1.4$ & $65.6 \pm 3.7$ & $63.6 \pm 1.4$ & $59.8 \pm 1.7$ & $63.0 \pm 3.4$ \\
1991 & E & $67.4 \pm 4.8$ & $64.2 \pm 1.4$ & $61.5 \pm 3.5$ & $58.5 \pm 1.8$ & $62.9 \pm 4.4$ \\
& W & $69.0 \pm 3.2$ & $60.4 \pm 2.1$ & $63.4 \pm 2.6$ & $59.9 \pm 1.8$ & $63.2 \pm 4.3$ \\
1992 & E & $68.4 \pm 0.8$ & $64.4 \pm 1.1$ & $60.7 \pm 1.9$ & $57.8 \pm 2.2$ & $62.7 \pm 4.0$ \\
& W & $65.9 \pm 0.9$ & $62.5 \pm 1.9$ & $57.1 \pm 2.2$ & $57.3 \pm 0.6$ & $60.4 \pm 3.9$ \\
\hline
\end{tabular}

The EAST (E) location pasture was used for intake trials in 1988 and 1989 and as a replicate pasture in 1990-1992.

${ }^{2}$ Monthly values are means of 3 to 6 sample collections.

barley + P supplement compared to the control treatment $(1.10 \mathrm{vs} 0.88 \mathrm{~kg})$. There was also a significant $(\mathrm{P}<0.14)$ location by treatment interaction. Daily gains of steers at the EAST location were again higher than at the WEST location (1.10 vs $0.91 \mathrm{~kg} ; \mathrm{P}<0.07)$.

\section{0}

There were no significant treatment differences in 1990 (P > 0.20; Table 6); however, there was a significant treatment by location interaction $(P<0.05)$. Steers at the WEST location tended to benefit more from the barley $+\mathrm{P}$ supplement [(barley + P) - control $=0.26 \mathrm{~kg}$ ] than steers at the EAST location [(barley $+\mathrm{P})-$ control $=$ $0.06 \mathrm{~kg}]$. Steers at the EAST location continued to gain more than WEST location steers, but the difference was not as great as in previous years $(1.10 \mathrm{vs} 0.99 \mathrm{~kg} ; \mathrm{P}<0.08)$.

\section{1 and 1992}

Because the barley + soybean treatment used in 1990 had shown little benefit, it was eliminated so that the number of steers per treatment could be increased from 5 to 7 . Barley significantly $(\mathrm{P}<0.05)$

Table 6. Average daily gains of yearling steers grazing native rangelands in the Northern Great Plains and supplemented with energy, phosphorus, and/or crude protein in 1988, 1989, 1990, 1991, and 1992.

\begin{tabular}{|c|c|c|c|c|c|c|c|}
\hline \multirow[b]{2}{*}{ Year } & \multirow[b]{2}{*}{$\begin{array}{c}\text { Steers/ } \\
\text { Treatment }\end{array}$} & \multicolumn{5}{|c|}{ Treatments } & \multirow[b]{2}{*}{ SE } \\
\hline & & $\mathrm{C}^{1}$ & $\mathrm{~B}^{1}$ & $\mathrm{BS}^{1}$ & $\mathrm{BP}^{1}$ & $\mathrm{BSP}^{1}$ & \\
\hline & & \multicolumn{6}{|c|}{ 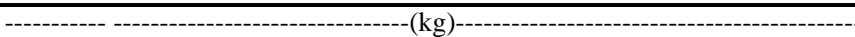 } \\
\hline $\begin{array}{l}1988 \\
1989\end{array}$ & $\begin{array}{l}11 \\
13\end{array}$ & $\begin{array}{l}0.80^{\mathrm{a}} \\
088^{\mathrm{b}}\end{array}$ & $\begin{array}{l}0.90^{\mathrm{a}} \\
1 . \mathrm{ab}\end{array}$ & -- & $\begin{array}{l}0.93^{\mathrm{a}} \\
1.0^{\mathrm{a}}\end{array}$ & -- & $\begin{array}{l}0.05 \\
0.05\end{array}$ \\
\hline $\begin{array}{l}1909 \\
1990\end{array}$ & $\begin{array}{l}15 \\
10\end{array}$ & $0.95^{\mathrm{a}}$ & $0.98^{\mathrm{a}}$ & $1.08^{\mathrm{a}}$ & $1.11^{\mathrm{a}}$ & $1.10^{\mathrm{a}}$ & 0.06 \\
\hline $1991^{2}$ & 14 & $0.73^{\mathrm{c}}$ & $0.94^{\mathrm{ab}}$ & -- & $0.89^{\mathrm{b}}$ & $0.98^{\mathrm{a}}$ & 0.01 \\
\hline $1992^{2}$ & 14 & $0.88^{\mathrm{c}}$ & $1.05^{\mathrm{b}}$ & -- & $1.17^{\mathrm{a}}$ & $1.15^{\mathrm{a}}$ & 0.02 \\
\hline \multicolumn{8}{|c|}{ Combined analysis of treatments common to all years ${ }^{.2,3}$} \\
\hline & 62 & $0.85^{\mathrm{c}}$ & $0.98^{\mathrm{b}}$ & -- & $1.04^{\mathrm{a}}$ & -- & 0.02 \\
\hline
\end{tabular}

${ }^{\mathrm{C}} \mathrm{C}=$ Control, (no supplement); $\mathrm{B}=$ ground barley; $\mathrm{BS}=$ ground barley and soybean meal; $\mathrm{BP}=$ ground barley and monosodium phosphate; and BSP=ground barley, soybean meal and monosodium phosphate.

${ }^{2}$ In 1989, treatments with different letters differed significantly at $(\mathrm{P}<.15)$. In 1991, 1992, and over all 5 years, treatments with different letters differed significantly at $(\mathrm{P}<0.05)$.

${ }^{3}$ Least squares means. supplementation results were affected by feeding at a constant rate compared to a gradually increased rate. Weight gains were not affected $(\mathrm{P}>0.20)$ by feeding method. However, feeding at a gradually increasing level would be more desirable because steers would more readily consume a small amount of feed in the early summer and increasing supplement levels would more nearly coincide with decreasing forage quality later in the summer.

In these studies the most consistent response was from barley (energy supplement), which agrees with results reported by Denham (1975) and Vadiveloo and Holmes (1979), but disagrees with Lusby et al. (1981) who reported a beneficial effect from protein but not from energy. Supplemental $\mathrm{P}$ produced inconsistent results among years but over all 5 years it significantly increased ADG compared to barley alone. Winks et al. (1977) in Australia also reported erratic results with $\mathrm{P}$ supplementation; in the wet season, $\mathrm{P}$ supplementation increased weight gains, but in the dry season it did not.

Steers at the rolling EAST location on the control, barley, and barley $+\mathrm{P}$ treatments had higher weight gains each year compared to steers at the flat WEST location. The consistent weight gain difference between locations may have been due to generally higher quality diets (Tables 4 and 5) at the EAST location. This may also help to explain why steers at the EAST location did not respond as well to supplements. Forage availability was not considered to be a limiting factor at either location during these studies.

\section{Intake}

During the summer of 1988, dry matter intake in early July was significantly lower than for other periods when expressed as $\mathrm{kg} / \mathrm{day}$, but intake was not significantly different among periods when expressed as a percent of body weight (Table 7). In 1989, dry matter intake as a percent of body weight and in $\mathrm{kg}$ /day generally declined throughout the season. Dry matter intakes expressed as a percent of body weight for control, barley, and barley $+\mathrm{P}$ supplement treatments were $2.7,2.9$ and $3.0 \%$, respectively, in 1988 and $2.7,2.6$ and $2.8 \%$, respectively, in 1989. However, treatments were not significantly different $(\mathrm{P}>0.05)$ either year and there was no treatment by period interaction.

Intake trials were conducted in 1991 and 1992 at both the EAST and WEST locations to determine if the higher ADG of 
Table 7. Daily dry matter intakes by period averaged across supplemental treatments in 1988 and 1989. ${ }^{1,2}$

\begin{tabular}{|c|c|c|c|c|c|}
\hline \multirow{3}{*}{ Trial } & \multirow{3}{*}{ Period } & \multirow{2}{*}{\multicolumn{2}{|c|}{$\begin{array}{c}1988 \\
\text { Dry Matter }\end{array}$}} & \multirow{2}{*}{\multicolumn{2}{|c|}{$\begin{array}{c}1989 \\
\text { Dry Matter }\end{array}$}} \\
\hline & & & & & \\
\hline & & (\% B.W.) & $\left(\mathrm{kg} \mathrm{day}^{-1}\right)$ & (\% B.W.) & $\left(\right.$ kg day $\left.^{-1}\right)$ \\
\hline 1 & Early Jul. & $2.7 \mathrm{a}$ & $9.6 \mathrm{~b}$ & $3.2 \mathrm{a}$ & $12.4 \mathrm{a}$ \\
\hline 2 & Late Jul. & $3.0 \mathrm{a}$ & $11.4 \mathrm{a}$ & $2.8 \mathrm{~b}$ & $11.0 \mathrm{ab}$ \\
\hline 3 & Mid Aug. & $3.0 \mathrm{a}$ & $11.9 \mathrm{a}$ & $2.6 \mathrm{~b}$ & $11.1 \mathrm{ab}$ \\
\hline 4 & Early Sep. & $3.0 \mathrm{a}$ & $12.6 \mathrm{a}$ & $2.6 \mathrm{~b}$ & $11.6 \mathrm{ab}$ \\
\hline \multirow[t]{2}{*}{5} & Late Sep. & $2.8 \mathrm{a}$ & $12.4 \mathrm{a}$ & $2.3 \mathrm{c}$ & $10.6 \mathrm{~b}$ \\
\hline & SE & 0.10 & 0.44 & 0.08 & 0.45 \\
\hline
\end{tabular}

Means are averages of 15 values in 1988 and 18 values in 1989.

Table 8. Dry matter intakes for control (C) and supplemented (BSP) steers for early and late summer in 1991 and 1992.,

\begin{tabular}{|c|c|c|c|c|c|c|c|c|}
\hline \multirow[b]{2}{*}{ Period } & \multicolumn{8}{|c|}{ Dry Matter } \\
\hline & $\mathrm{C}$ & BSP & $\begin{array}{c}\text { Period } \\
\text { mean }\end{array}$ & SE & $\mathrm{C}$ & BSP & $\begin{array}{l}\text { Period } \\
\text { mean }\end{array}$ & SE \\
\hline & & \multicolumn{3}{|c|}{ (\% of B.W.) } & \multicolumn{4}{|c|}{ 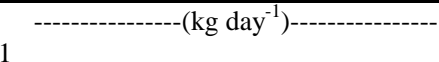 } \\
\hline Early Summer & 2.2 & 2.2 & $2.2 \mathrm{a}$ & 0.08 & 8.5 & 8.1 & $8.3 \mathrm{a}$ & 0.33 \\
\hline Late Summer & 1.8 & 2.2 & $2.0 \mathrm{a}$ & 0.08 & 7.6 & 9.6 & $8.6 \mathrm{a}$ & 0.33 \\
\hline Treatment Mean & $2.0 \mathrm{a}$ & $2.2 \mathrm{a}$ & & & $8.0 \mathrm{a}$ & $8.9 \mathrm{a}$ & & \\
\hline \multirow[t]{2}{*}{ SE } & 0.09 & 0.09 & & & 0.37 & 0.37 & & \\
\hline & \multicolumn{8}{|c|}{$\underline{1992}$} \\
\hline Early Summer & 2.3 & 2.5 & $2.4 \mathrm{a}$ & 0.11 & 8.8 & 10.0 & $9.4 \mathrm{a}$ & 0.49 \\
\hline Late Summer & 2.3 & 2.6 & $2.5 \mathrm{a}$ & 0.12 & 10.0 & 12.2 & $11.1 \mathrm{~b}$ & 0.51 \\
\hline Treatment Mean & $2.3 \mathrm{a}$ & $2.6 b$ & & & $9.4 \mathrm{a}$ & $11.1 \mathrm{~b}$ & & \\
\hline SE & 0.09 & 0.09 & & & 0.54 & 0.53 & & \\
\hline
\end{tabular}

Dry matter intake was not significantly different between locations either year.

Within a year, least squares treatment means with different letters differ $(\mathrm{P}<0.07)$

${ }^{3}$ Within a year, least squares period means with different letters differ $(\mathrm{P}<0.05)$.

steers at the EAST location could be due to higher dry matter intakes. Trials conducted in early and late summer of each year indicated that dry matter intake did not differ $(\mathrm{P}>0.05)$ between locations (data not shown). In 1991 dry matter intake was not different between early and late summer trials (Table 8). However, in 1992 dry matter intake in kilograms per steer per day was higher in late summer. Dry matter intake tended to be numerically higher for supplemented steers in the 1991 late summer trial and was significantly higher $(\mathrm{P}<0.07)$ for supplemented steers over both trials in 1992 (Table 8).

\section{Conclusions}

Average daily gains and the inconsistent response to supplementation between years and locations suggests that the nutrient content and dry matter intake of grazed forage in these studies were quite high. Ground barley was usually beneficial, whereas $\mathrm{P}$ was beneficial in some years and locations, but crude protein showed little benefit. Over all 5 years, ground barley and ground barley plus $\mathrm{P}$ increased ADG by 0.13 and $0.19 \mathrm{~kg}$, respectively, above unsupplemented steers. In most years, feeding a supplement containing a combination of ground barley and $\mathrm{P}$ should be beneficial, but the response to supplements will vary according to the quantity and quality of available forage. Feeding gradually increasing levels of supplement during the summer would probably be a more desirable supplementation approach because steers would more readily consume small amounts of supplement early in the summer and larger amounts of supplement in late summer. This supplementation pattern would also help to compensate for expected declines in forage nutritive quality.

\section{Literature Cited}

Adams, D. C., T. C. Nelsen, W. L. Reynolds, and B. W. Knapp. 1986. Winter grazing activity and forage intake of range cows in the Northern Great Plains. J. Anim. Sci. 62:1240-1246.

Adams, D. C., R. E. Short, M. M. Borman, and M. D. MacNeil. 1991. Estimation of fecal output with an intra-ruminal continuous release marker device. J. Range Manage. 44:204-207.

Call, J. W., J. E. Butcher, J. T. Blake, R. A. Smart, and J. L. Shupe. 1978. Phosphorus influence on growth and reproduction of beef cattle. J. Anim. Sci. 47:216-225.
Denham, A. H. 1975. Energy supplementation for steers grazing rye pasture and native range. Prog. Rep. Colorado Exp. Sta. October 1975. PR75-53.

Echevarria, M. G., C. Reyes, N. Clavo, J. Rodriguez, R. Valdivia, and L. R. McDowell. 1987. Phosphorus supplementation of Nellore steers fed Yaragua/Stylo mixture in the Peruvian Tropics. Trop. Anim. Health. Prod. 19:143-146.

Ellis, W. C., E. M. Bailey, and C. A. Taylor. 1984. A silicone esophageal cannula; its surgical installation and use in research with grazing cattle, sheep or goats. J. Anim. Sci. 59:204-209.

Goering, H. K. and P. J. Van Soest. 1970. Forage fiber analyses. Agr. Handb. No. 379, USDA.

Hoehne, O. E., D. C. Clanton, and C. L. Streeter. 1967. Chemical changes in esophageal fistula samples caused by salivary contamination and sample preparation. J. Anim Sci. 26:626-631.

Karn, J. F. 1992. Ad. Libitum phosphorus supplementation of range cows in the Northern Great Plains. J. Prod. Agr. 5:409-413.

Karn, J. F. and L. Hofmann. 1990. Relationships between pasture forage components and fecal chemical composition. J. Range Manage. 43:320-325.

Lusby, K. S., G. W. Horn, and M. J. Dvorak. 1981. Energy vs protein supplementation of steers grazing native range in late summer and early fall. Oklahoma Agr. Exp. Sta. Res. Rep. No. 112 pp. 36-39.

Milliken, G.A. and D.E. Johnson. 1984. Analysis of messy data. Vol. 1: Designed Experiments. Lifetime Learning Publications, Belmont, Calif.

Moore, J.E. and G.O. Mott. 1974. Recovery of residual organic matter from in vitro digestion of forages. J. Dairy Sci. 57:1258-1259.

NRC. 1996. Nutrient requirements of domestic animals. Nutrient requirments of beef cattle. 7 th ed. Nat. Acad. Sci., Washington,DC.

SAS. 1985. SAS user's guide: Statistics. SAS Inst., Inc. Cary, N.C.

Reyneke, J. 1976. Supplementation of energy and/or protein to steers grazing summer veld. $S$. Afr. J. Anim. Sci. 6:59-66.

Rittenhouse, L.R., D.C. Clanton, and C.L. Streeter. 1970. Intake and digestibility of winter-range forage by cattle with and without supplements. J. Anim. Sci. 31:1215-1221.

Tilley, J. M. A. and R. A. Terry. 1963. A two-stage technique for the in vitro digestion of forage crops. J. Br. Grassl. Soc. 18:104-111.

Vadiveloo, J. and W. Holmes. 1979. Supplementary feeding of grazing beef cattle. Grass and Forage Sci. 34:173-179.

Williams, C. H., D. J. David, and O. Iismaa. 1962. The determination of chromic oxide in faeces samples by atomic absorption spectrophotometry. J. Agr. Sci. 59:381-385.

Winks, L., F. C. Lamberth, and P. K. O'Rourke. 1977. The effect of a phosphorus supplement on the performance of steers grazing Townsville stylo-based pasture in north Queensland. Aust. J. Exp. Agr. Anim. Husb. 17:357-366.

Winter, W. H. 1988. Supplementation of steers grazing Stylosanthes hamata pastures at Katherine, Northern Territory. Aust. J. Exp. Agr. 28:669-682. 


\title{
Spotted knapweed and grass response to herbicide treat- ments
}

\author{
ROGER L. SHELEY, CELESTINE A. DUNCAN, MARY B. HALSTVEDT, AND JAMES S. JACOBS
}

Authors Sheley and Jacobs are associate professor and post-doctoral research associate, Land Resources \& Environ. Sci., Montana State Univ., Bozeman,

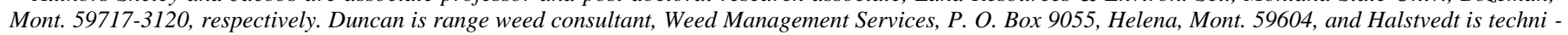
cal service representative, DowElanco 2155 Carriage Dr., LRP, Estes Park, Colo. 80517,

\begin{abstract}
Picloram at $0.28 \mathrm{~kg}^{\mathrm{ai}} \mathrm{ha}^{-1}$, clopyralid plus 2,4-D at $0.21 \mathrm{~kg}$ ai $\mathrm{ha}^{-1}$ plus $1.12 \mathrm{~kg} \mathrm{ai} \mathrm{ha}^{-1}$, or dicamba plus 2,4-D at $0.56 \mathrm{~kg}^{\mathrm{ai} \mathrm{ha}} \mathrm{ha}^{-1}$ plus $1.12 \mathrm{~kg}$ ai ha ${ }^{-1}$ were applied to spotted knapweed (Centaurea maculosa Lam.) at the spring-rosette, bolt, bud, flower, or fallrosette growth stages in 1991 on 2 sites in Montana. Treatments ( 3 herbicide treatments, 5 growth stages) were applied in a randomized-complete-block design and replicated 3 times at each site. Effects of herbicides on mature and seedling spotted knapweed density depended upon spotted knapweed growth stage at the time of application and the number of years after application. Picloram consistently reduced mature spotted knapweed density to low levels $\left(<5\right.$ plants $\left.\mathrm{m}^{-2}\right)$, regardless of growth stage, and its effect persisted through 1994. Clopyralid plus 2,4-D applied at the bolt or bud stage reduced spotted knapweed densities similar to that of picloram $(95 \%)$ at the Avon site, while providing about $\mathbf{5 0 \%}$ reduction in density 3 years after application at Missoula. This treatment may provide an alternative to picloram in environmentally sensitive areas. Dicamba plus 2,4-D was most effective when applied during the bud and bolt growth stages, and least effective when applied during the spring- and fall-rosette stages. In most situations, picloram and clopyralid plus 2,4-D provided greater control of spotted knapweed than dicamba plus 2,4-D. Herbicide treatments increased perennial grass biomass from $173 \mathrm{~kg} \mathrm{ha}^{-1}$ in the nontreated controls to 494, 880, and 1,309 $\mathrm{kg} \mathrm{ha}^{-1}$ for dicamba plus 2,4-D, clopyralid plus 2,4-D and picloram, respectively.
\end{abstract}

Key Words: Pasture and rangeland weed control, clopyralid, dicamba, picloram, 2,4-D, Centaurea maculosa

Spotted knapweed (Centaurea maculosa Lam.), a short-lived perennial weed, was introduced to the Pacific Northwest from Eurasia about 1900 (Roché and Talbott 1986). Since its introduction, spotted knapweed has aggressively invaded rangeland and open canopy forest sites in the northern intermountain region (Lacey et al. 1992, Losensky 1987, Roché et al. 1986). More than 2.8 million ha in Montana and adjoining states and Canadian provinces are infested with spotted knapweed (Lacey 1989). This weed can form dense infestations that reduce vigor and diversity of native plants (Forcella and Harvey 1983, Tyser and Key 1988).

Published with approval of the directors, Montana Agricultural Experiment Station as Journal No. J-5160 .

Manuscript accepted 10 July 1999.

\section{Resumen}

En 1991, en dos sitios de Montana, se aplicaron los herbicidas picloram $\left(0.28 \mathrm{~kg}^{\text {ia }} \mathrm{ha}^{-1}\right)$, clopiralid mas $2,4-\mathrm{D}\left(0.21 \mathrm{~kg}^{\mathrm{a}}\right.$ ia ha ${ }^{1}$ mas $1.12 \mathrm{~kg}$ ia ha $\left.{ }^{-1}\right)$ y dicamba mas $2.4-\mathrm{D}(0.56 \mathrm{~kg}$ ia ha-1 mas $1.12 \mathrm{~kg}$ ia ha-1) a "Spotted knapweed" (Centaurea maculosa Lam.) en las etapas de desarrollo: roseta de primavera, aparición de tallos florales, yemas, flores, floración y roseta de otoño. Los tratamientos ( 3 herbicidas y 5 etapas de desarrollo) se aplicaron bajo un diseño experimental de Bloques completos al azar con 3 repeticiones en cada sitio. Los efectos de los herbicidas en la densidad de plantas maduras y plántulas de "Spotted knapweed" dependieron de la etapa de desarrollo en que se encontraba el "Spotted knapweed" al momento de la aplicación y del número de años después de la aplicación. El picloram redujo a niveles consistentemente bajos $\left(<5\right.$ plantas $\left.\mathrm{m}^{-2}\right)$ la densidad de plantas maduras de "Spotted knapweed', esto sin importar la etapa de desarrollo en la que se encontraban y el efecto persistió hasta 1994. En el sitio Avon, el clopiralid mas 2,4-D aplicado en las etapas de aparición de tallos florales o yemas redujo la densidad de "Spotted knapweed" en forma similar que el picloram $(95 \%)$, en tanto que en el sitio de Missoula, después de 3 años de la aplicación, la redujo en $50 \%$. Este tratamiento puede proveer una alternativa al picloram en áreas ambientalmente sensitivas. El dicamba mas 2,4-D fue mas efectivo cuando se aplico durante las etapas de aparición de yema $y$ tallos florales y menos efectivo cuando se aplico durante los estados de roseta de primavera y otoño. En la mayoría de los casos picloram y clopiralid mas 2,4-D controlaron mejor el "Spotted knapweed" que dicamba mas 2,4-D. Los tratamientos de herbicidas incrementaron la biomasa de pastos perennes de $173 \mathrm{~kg} \mathrm{ha}^{-1}$ en las áreas sin tratamiento a 494, 880, y $1,309 \mathrm{~kg}$ $\mathrm{ha}^{-1}$ cuando se aplico dicamba mas 2,4-D, clopiralid mas 2,4-D y picloram respectivamente.

Spotted knapweed reduces forage production from 60 to $90 \%$, which causes economic losses to the livestock industry and impairs wildlife populations (Watson and Renney 1974, Bucher 1984, Bedunah and Carpenter 1989). Spotted knapweed costs the livestock industry $\$ 11$ million each year in direct costs, and could cost the industry $\$ 155$ million if allowed to spread to its potential ecological range in Montana (Hirsh and Leitch 1996).

Integrating biological, cultural, and chemical control methods will be necessary to effectively manage large infestations of spotted knapweed (Cuda et al. 1989, Sheley et al. 1996). At this time, biological control with insects, pathogens, and grazing animals 
Table 1. Average seasonal precipitation (cm) during the 4-year study (1991 to 1994) and long-term precipitation at a recording station located 6.4 km from the Missoula study site (Missoula WSO) and $24.1 \mathrm{~km}$ from the Avon study site (Ovando).

\begin{tabular}{|c|c|c|c|c|c|c|c|c|c|c|c|}
\hline \multirow[b]{2}{*}{ Months } & \multicolumn{2}{|c|}{1991} & \multicolumn{2}{|c|}{1992} & \multicolumn{2}{|c|}{1993} & \multicolumn{2}{|c|}{1994} & \multicolumn{2}{|c|}{$\begin{array}{l}4-y r \\
\text { Mean }\end{array}$} & \multirow{2}{*}{$\begin{array}{c}\text { Long term } \\
\text { Average } \\
\text { Msla }\end{array}$} \\
\hline & $\mathrm{Msla}^{\mathrm{b}}$ & Avon & Msla & Avon & Msla & Avon & Msla & Avon & Msla & Avon & \\
\hline & & & & & & $(\mathrm{cm})$ & & & & & - \\
\hline Jan-Mar & 5.8 & 3.1 & 7.7 & 2.8 & 5.5 & 3.3 & 3.4 & 2.0 & 5.6 & 2.8 & 7.6 \\
\hline Apr-Jun & 13.9 & 11.0 & 11.4 & 9.5 & 13.3 & 12.1 & 15.8 & 17.1 & 13.6 & 12.4 & 8.7 \\
\hline Jul-Sep & 3.0 & 4.7 & 7.8 & 7.2 & 9.4 & 18.7 & 3.9 & 3.0 & 6.0 & 8.4 & 8.1 \\
\hline Oct-Dec & 7.4 & 6.4 & 5.8 & 4.9 & 7.3 & 3.3 & 6.4 & 6.1 & 6.7 & 5.2 & 6.8 \\
\hline Total & 30.1 & 24.9 & 32.7 & 24.1 & 35.5 & 37.4 & 29.5 & 28.2 & 31.9 & 28.8 & 31.2 \\
\hline
\end{tabular}

${ }^{\mathrm{a}}$ No long term data available for Avon study site.

${ }^{\mathrm{b}}$ Msla=Missoula study site.

has shown limited success in reducing spotted knapweed density (Story 1992, Lacey et al. 1994, Olson et al. 1997). Mechanical treatments are restricted by soil type and terrain on many rangeland sites. Therefore, herbicides are a necessary component of most successful integrated weed management projects.

Previous studies of other perennial weeds, such as leafy spurge (Euphorbia esula L.) and Russian knapweed (Acroptilon repens L.) indicate that herbicide efficacy depends upon the growth stage at the time of application (Lym and Messersmith 1983, Whitson et al. 1993). Studies focusing on the effect of application timing on spotted knapweed control are limited. Whitson et al. (1986) reported that spotted knapweed could be controlled easily with either spring or fall herbicide applications. In another study, spotted knapweed control was similar 2 months after application when herbicides were applied at the bud or flower stage (Lym and Messersmith 1986). Early spring treatments using picloram, clopyralid plus 2,4$\mathrm{D}$, and dicamba plus 2,4-D are commonly recommended to control spotted knapweed and increase forage production (Harris and Cranston 1979, Lacey et al. 1992, Lacey 1985, Fay et al. 1995).

No long-term studies report the optimum timing of herbicide application to maximize spotted knapweed control and subsequent forage production. Specific objectives of this study were to evaluate spotted knapweed control using picloram, clopyralid plus 2,4-D, and dicamba plus 2,4-D, and to determine the optimum growth stage at which to apply herbicides to maximize spotted knapweed control and grass production.

\section{Materials and Methods}

\section{Study Sites}

This study was conducted near Missoula and Avon, Mont., from 1991 through 1994. The Avon site was located on native rangeland with a long-term grazing history of light to moderate use $(0-50 \%$ utilization, annually). The area had not been grazed for 8 years prior to the study. The Missoula site was seeded with crested wheatgrass [Agropyron cristatum (L.) Gaertn.] during the 1940s and had not been grazed by livestock since the 1930s. Although neither site was grazed by domestic livestock during the study, some use by wildlife was noted.

The Avon site was located on a nearly level floodplain at $1455 \mathrm{~m}$ elevation. Soil was a Typic Haploboroll with a gravelly loam texture, $3.9 \%$ organic matter, and $\mathrm{pH}$ 5.8. The Missoula site was located on foothills at $975 \mathrm{~m}$ elevation with a northwest aspect. Soil was a Typic Argiboroll with a gravelly loam texture, $4.8 \%$ organic matter, and $\mathrm{pH}$ 6.2. Average seasonal precipitation during the 4-year study at both sites, and long-term precipitation near
Missoula are presented in Table 1.

Rough fescue (Festuca scabrella Torr.), bluebunch wheatgrass [Pseudoroegneria spicatum (Prush) Love], prairie junegrass (Koeleria cristata (L.) Pers.), and Idaho fescue (Festuca idahoensis Elmer) were dominant grasses at Avon. Crested wheatgrass was the most abundant grass at the Missoula location. Spotted knapweed was the dominant forb at both locations, averaging 36 mature plants $\mathrm{m}^{-2}$ at each site.

\section{Procedures}

Herbicides were applied using a $\mathrm{CO}_{2}$ backpack sprayer equipped with a $3.1-\mathrm{m}$, 6-nozzle spray boom, calibrated to deliver 168 liters ha ${ }^{-1}$. Plot size was 3.1 by $9.1 \mathrm{~m}$. Picloram was applied at $0.28 \mathrm{~kg}$ active ingredients (ai) ha ${ }^{-1}$, clopyralid plus $2,4-\mathrm{D}$ at $0.21 \mathrm{~kg}$ ai ha-1 plus $1.12 \mathrm{~kg}$ ai ha-1 $\mathrm{ha}^{-1}$, and dicamba plus 2,4-D at $0.56 \mathrm{~kg}$ ai ha- $\mathrm{has}^{-1}$ plus $1.12 \mathrm{~kg}$ ai ha ${ }^{-1}$. Applications were made when spotted knapweed was at the springrosette, bolt, bud, flower, or fall-rosette growth stage during 1991 (Table 2). Treatments ( 3 herbicide treatments, 5 growth stages) were applied in a randomized--complete-block design and replicated 3 times at each site.

\section{Sampling}

Spotted knapweed density was determined in 3 randomly located $0.25-\mathrm{m}^{2}$ quadrants per plot during flowering in 1992, 1993, and 1994. Spotted knapweed

Table 2. Five phenological stages of spotted knapweed and dates of herbicide application at 2 study sites in western Montana.

\begin{tabular}{|c|c|c|c|}
\hline \multirow{2}{*}{$\begin{array}{l}\text { Spotted knapweed } \\
\text { growth stage }\end{array}$} & \multirow[t]{2}{*}{ Growth stage description } & \multicolumn{2}{|c|}{ Herbicide application date } \\
\hline & & Missoula & Avon \\
\hline Rosette & plants $50-150 \mathrm{~mm}$ diamter & 12 May 1991 & 17 May 1991 \\
\hline Bolt & $\begin{array}{l}85 \% \text { of plants @ } 125-230 \mathrm{~mm} \text { bolt } \\
15 \% \text { of plants @ } 50-125 \mathrm{~mm} \text { bolt }\end{array}$ & 7 June 1991 & 11 June 1991 \\
\hline Bud & $\begin{array}{l}75 \% \text { of plants @ mid-bud stage } \\
25 \% \text { of plants @ early-bud stage }\end{array}$ & 25 June 1991 & 3 July 1991 \\
\hline Flower & mid-flower stage; $90 \%$ of plants flowering & 1 Aug. 1991 & 3 Aug. 1991 \\
\hline Fall regrowth & basal rosettes expanded to $50-150 \mathrm{~mm}$ diameter & 12 Sept. 1991 & 12 Sept. 1991 \\
\hline
\end{tabular}


plants were categorized as seedlings (defined as those that germinated during the current growing season and had 1 to 5 leaves) or mature plants (defined as those that had been growing for more than a season and had more than 5 leaves). Above-ground perennial grass biomass was harvested at peak standing crop during the third growing season following application. Plant material was clipped to a height of $1 \mathrm{~cm}$ within the $0.25-\mathrm{m}^{2}$ quadrats after spotted knapweed density had been determined. Samples were dried in a ventilated, heated $\left(45^{\circ} \mathrm{C}\right)$ room to a constant weight (168 hours) and weighed. Perennial grasses were not separated by species during sampling because the objective was to determine overall response of perennial grasses to herbicide treatments.

\section{Analysis}

All data were pooled and analyzed using analyses of variance. Site differences were detected; therefore, each site was analyzed separately. The model used for determining treatment differences in spotted knapweed density was a split-plot in time with herbicide treatment, growth stage, and herbicide treatment by growth stage tested using replication by herbicide treatment by growth stage as the error term. Year, year by herbicide treatment, year by growth stage, year by herbicide treatment by growth stage were analyzed as wholeplots. Biomass data were analyzed as a randomized-complete-block design. Herbicide treatment and growth stage at time of application were main effects. Herbicide by growth stage interaction was included in the model. All other sources of variation were pooled into the error term. Mean separations were made using

Table 3. Mean squares generated from analysis of variance of spotted knapweed density data.

\begin{tabular}{|c|c|c|c|c|c|}
\hline \multirow[b]{3}{*}{ Source of variation } & \multirow[b]{3}{*}{ Df } & \multicolumn{4}{|c|}{ Mean square } \\
\hline & & \multicolumn{2}{|c|}{ Missoula } & \multicolumn{2}{|c|}{ Avon } \\
\hline & & Mature & Seedlings & Mature & Seedlings \\
\hline Rep & 2 & 525 & 178326 & 48 & 20267 \\
\hline Herb & 3 & $26868 * *$ & $4038920 * *$ & $10638 * *$ & $1490652 * *$ \\
\hline Stage & 4 & $3091 * *$ & $485239 * *$ & $302 * *$ & $38005^{* *}$ \\
\hline Herb $*$ Stage & 12 & $2080 * *$ & $193600 * *$ & $272 * *$ & $21639 * *$ \\
\hline Error A & 38 & 3040 & 63215 & $50 * *$ & 11806 \\
\hline Year & 2 & $2002 * *$ & $1022605^{* * *}$ & $1275^{* *}$ & $72193 * *$ \\
\hline Year * Herb & 6 & $401 *$ & $67794 * *$ & $360 * *$ & $33598 * *$ \\
\hline Year * Stage & 8 & 151 & 20457 & 28 & 7502 \\
\hline Year $*$ Herb $*$ Stage & 24 & 1090 & $33743 * *$ & $69 * *$ & 7625 \\
\hline Error B & 80 & 30 & 15764 & 22 & 7072 \\
\hline
\end{tabular}

$\mathrm{a}^{*, * *}$ significant at the $5 \%$ and $1 \%$ levels of probability, respectively.

Fisher's protected LSD's at $\mathrm{P}=0.05$ (Peterson 1985).

\section{Results}

\section{Mature Spotted Knapweed Density}

At Missoula, analysis of variance indicated that the effect of herbicide treatments on mature spotted knapweed density depended upon the growth stage at which the herbicides were applied (Table 3). Applied at the spring-rosette stage, picloram and clopyralid plus 2,4-D reduced the number of mature spotted knapweed plants similarly for 3 years following treatment (Fig. 1). Dicamba plus 2,4-D reduced spotted knapweed density to about $50 \%$ compared to the control, but knapweed density was about 4 times greater than in plots sprayed with either picloram or clopyralid plus 2,4-D. Treatments applied at the bolt growth stage yielded similar densities to those applied at the spring-rosette growth stage, except that dicamba plus 2,4-D reduced spotted knapweed density to about 5 plants $\mathrm{m}^{-2}$. This was similar to results of the clopyralid plus 2,4-D and picloram treatments. All herbicide treatments reduced mature spotted knapweed plant density similarly when applied at the bud growth stage. Picloram applied at the flower and fall-rosette growth stage yielded lowest spotted knapweed density at those stages. Clopyralid plus 2,4-D and dicamba plus 2,4-D yielded similar mature spotted knapweed densities at these growth stages. All herbicide treatments reduced spotted knapweed density below that of the control, regardless of growth stage at the time of application.

At Missoula, analysis of variance also indicated that the effect of herbicides on the density of mature spotted knapweed depended upon the year after application (Table 3). Picloram and clopyralid plus 2,4-D yielded the lowest mature spotted knapweed density in 1992 (Fig. 2). Dicamba plus 2,4-D reduced spotted knapweed density 3 times lower than that of

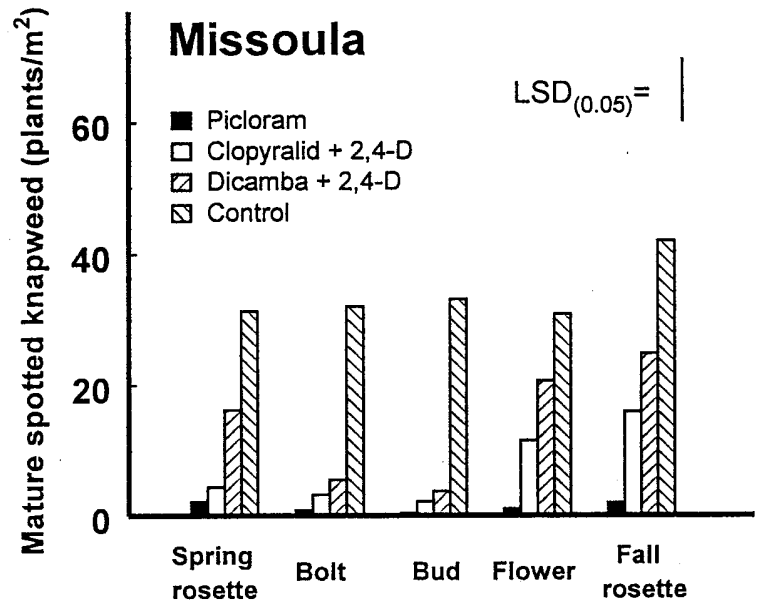

Fig. 1. Effect of herbicides applied at 5 growth stages on mature spotted knapweed at Missoula.

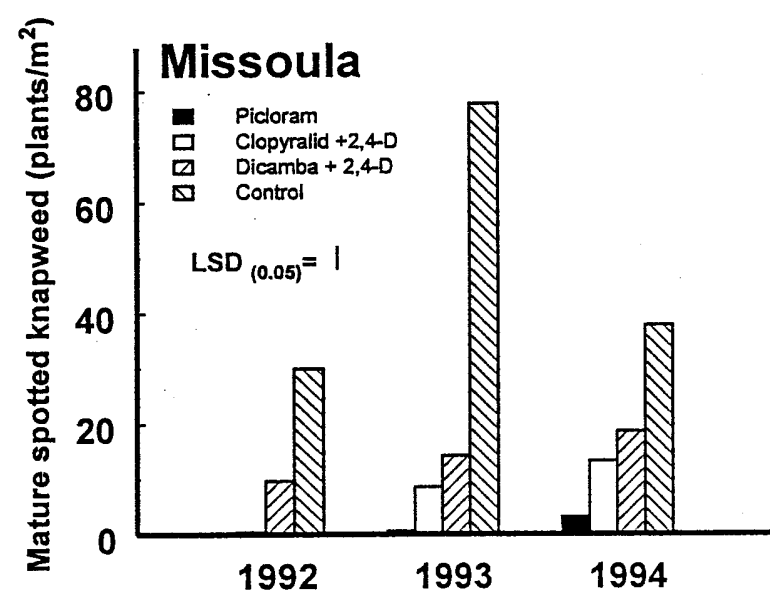

Fig. 2. Effect of herbicides each year following application on mature spotted knapweed at Missoula. 


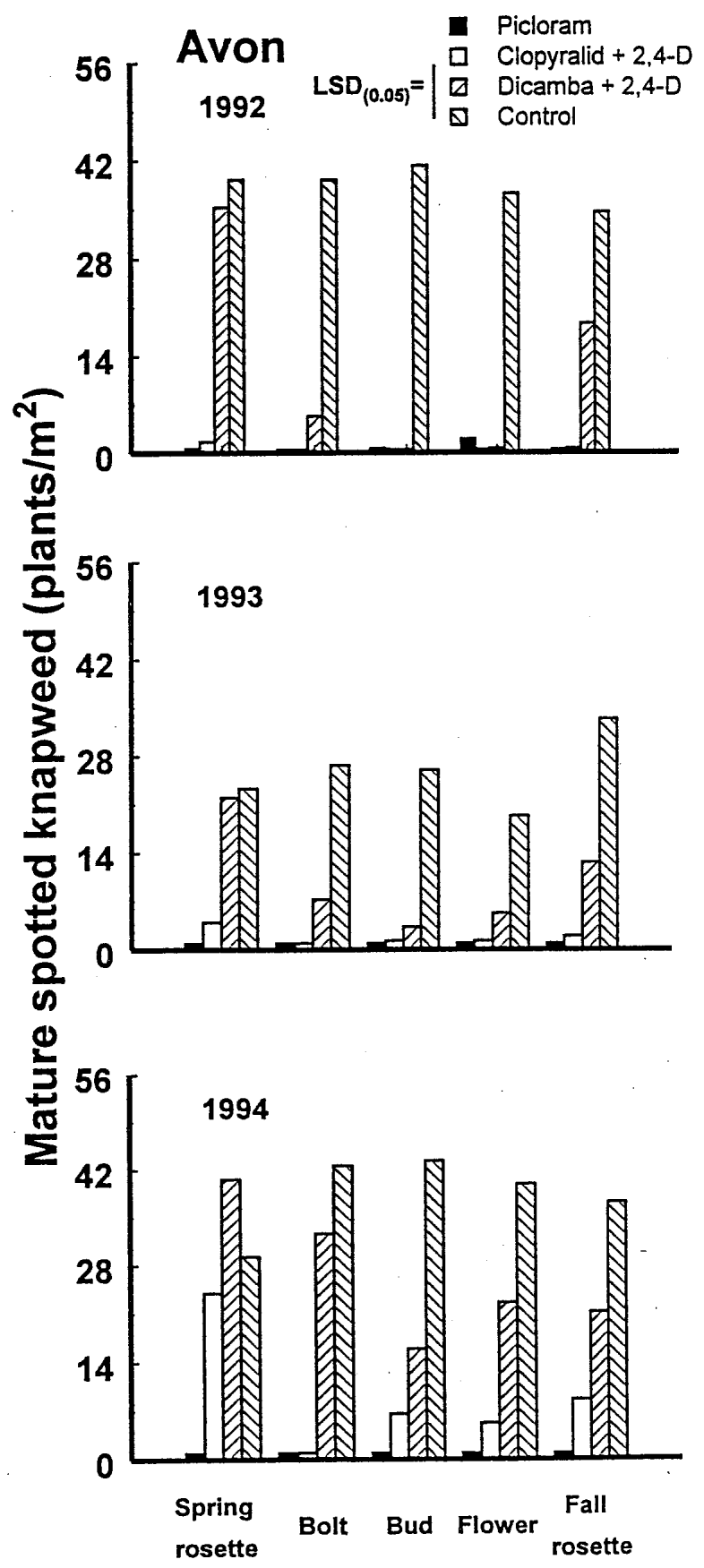

Fig. 3. Effect of herbicides applied at 5 growth stages on mature spotted knapweed in 1992, 1993, and 1994 at Avon. Comparisons can be made within or among bargraphs.

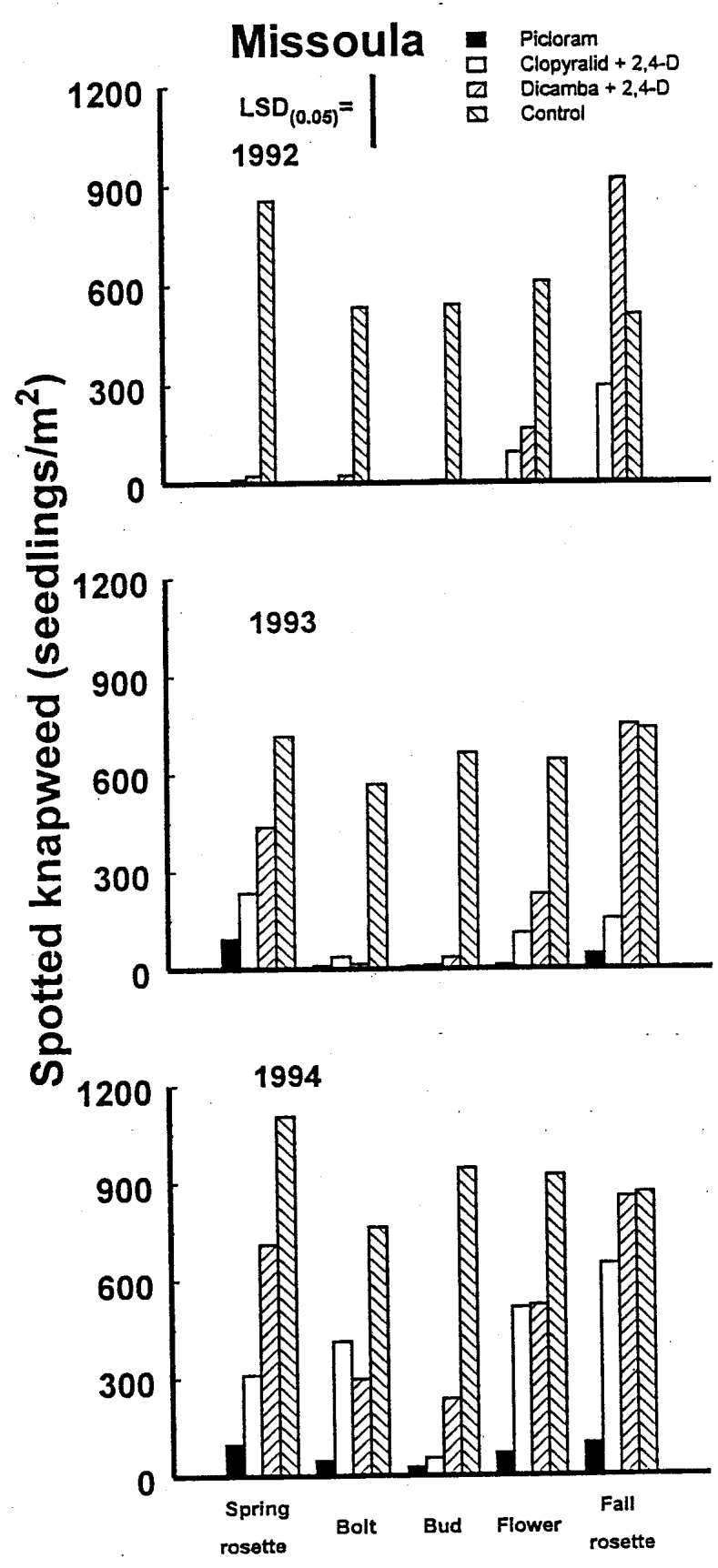

Fig. 4. Effect of herbicides applied at 5 growth stages on spotted knapweed seedlings in 1992, 1993, and 1994. Comparisons can be made within or among bargraphs. the control that year. In 1993 and 1994, third year after application. At Avon, picloram yielded the lowest spotted knapweed density. Spotted knapweed density in plots treated with clopyralid plus 2,4-D was about 8.5 and 13 plants $\mathrm{m}^{-2}$, while its density in plots treated with dicamba plus 2,4-D was about 14 and 19 plants $\mathrm{m}^{-2}$ in 1993 and 1994, respectively. All herbicide treatments reduced spotted knapweed density below that of the control, through the effect of the herbicide treatments on mature spotted knapweed density depended on the weeds growth stage and the number of years after application (Table 3 ). During each year and growth stage, picloram yielded nearly complete reduction of spotted knapweed density (Fig. 3). In 1992 and 1993, clopyralid plus 2,4-D reduced spotted knapweed density similarly to that of picloram at all growth stages. By 1994, only the bolting stage application of clopyralid plus 2,4-D remained as effective as picloram. This herbicide treatment was least effective when applied during the spring-rosette growth stage and moderately effective at the bud, flower, and fall-rosette growth stages by end of the study. In 1992, dicamba plus 2,4-D yielded nearly complete reduction of mature spotted knap- 
weed density when applied at the bud and flower growth stages at Avon (Fig. 3). After treatment at these growth stages, spotted knapweed density increased as years after application increased. Among the dicamba plus 2,4-D treatments, the bud stage application yielded the lowest mature spotted knapweed density in 1994. Application of dicamba plus 2,4-D at the bolt growth stage reduced spotted knapweed density to about 4 plant $\mathrm{m}^{-2}$ in 1992 , but the weed rapidly reestablished after this treatment. Dicamba plus 2,4-D applied at the fall-rosette growth stage reduced spotted knapweed density from about 35 to 20, 12, and 24 plants $\mathrm{m}^{-2}$ in 1992, 1993, and 1994 , respectively. Of the herbicide treatments, dicamba plus 2,4-D applied at the spring-rosette growth stage was the least effective in reducing mature spotted knapweed density.

\section{Spotted Knapweed Seedling Density}

At Missoula, effect of herbicide treatment on seedling spotted knapweed density depended upon growth stage and the time elapsed since application (Table 3 ). In 1992, picloram, clopyralid plus 2,4-D, and dicamba plus 2,4-D applied at the spring-rosette, bolt, bud, or flower growth stage provided similar seedling density reduction (Fig. 4). Picloram eliminated spotted knapweed seedlings for a full year when applied at the fall-rosette growth stage. Clopyralid plus 2,4-D and dicamba plus 2,4-D applied during the fall-rosette growth stage had seedling densities of 225 and 900 plant $\mathrm{m}^{-2}$, respectively, in 1992. In 1993, all 3 herbicide treatments provided similar density reduction, with the exception of dicamba plus 2,4-D applied at the spring-and fall-rosette growth stage. Dicamba plus 2,4-D applied in the springrosette growth stage yielded about 450 plants $\mathrm{m}^{-2}$, which was similar to that of clopyralid plus 2,4-D applied at the same stage that year. Dicamba plus 2,4-D applied at the fall-rosette growth stage yielded seedling densities similar to that of the control in 1993. By 1994, picloram and clopyralid plus 2,4-D yielded lowest seedling spotted knapweed density when applied at the spring-rosette growth stage. Dicamba plus 2,4-D reduced seedling densities of spotted knapweed by about 400 plant $\mathrm{m}^{-2}$ below that of the control applied at this growth stage. Applied at the bolt growth stage, picloram yielded the lowest number of spotted knapweed seedlings in 1994. Clopyralid plus 2,4-D and dicamba plus 2,4-D reduced spotted knapweed seedling density by about $50 \%$ at that time. In 1994, all 3 herbicide treatments

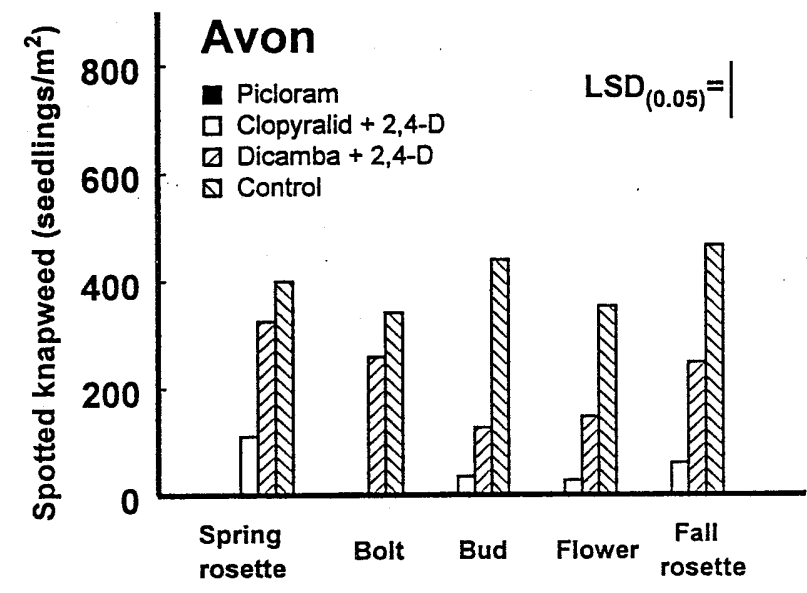

Fig. 5. Effect of herbicides applied at 5 growth stages on spotted knapweed seedlings at Avon.

yielded similar densities when applied at the bud growth stage. Applied at the flower and fall-rosette growth stages, picloram yielded the lowest seedling densities. Clopyralid plus 2,4-D applied at the flower growth stage reduced seedling spotted knapweed densities by about $50 \%$ of the control, but the herbicides effect was removed by 1994 when applied at the fall-rosette growth stage.

At Avon, analysis of variance indicated that the effect of herbicide treatments on spotted knapweed seedling density depended upon growth stage at which the herbicides were applied (Table 3). Picloram applied at any growth stage and clopyralid plus 2,4-D applied at bolt, bud, flower, and fall-rosette growth stages provided lowest spotted knapweed seedling density (Fig. 5). Clopyralid plus 2,4-D applied at the rosette growth stage lowered spotted knapweed seedling density to about 110 plants $\mathrm{m}^{-2}$. Dicamba plus 2,4-D did not reduce spotted knapweed seedling densities when applied at the spring-rosette or bolt growth stage. At all other growth stages, dicamba plus 2,4-D yielded densities ranging from 120 to 250 seedling $\mathrm{m}^{-2}$.

At Avon, analysis of variance also indicated the effect of herbicide treatment on spotted knapweed seedling density depended upon the year after application (Table 3$)$. Picloram (0 seedlings $\mathrm{m}^{-2}$ )and clopyralid plus 2,4-D (50 seedlings $\mathrm{m}^{-2}$ ) yielded lowest spotted knapweed seedling density all three years after application (Fig. 6). Dicamba plus 2,4-D yielded 239, 265 , and 159 seedling spotted knapweed plants $\mathrm{m}^{-2}$ in 1992,1993 , and 1994, respectively. All herbicide treatments reduced seedling spotted knapweed density below that of the control at this site.

\section{Grass biomass}

At the Missoula site, the effect of herbicide treatment on grass biomass 3 years after application depended upon the growth stage of spotted knapweed at the time of application (Table 4). Applied at the spring-rosette growth stage, picloram and clopyralid plus 2,4-D yielded greatest grass biomass, while dicamba plus 2,4-D yielded least grass biomass (Fig. 7). Applied at the bolt growth stage, picloram yielded highest grass biomass. Clopyralid plus 2,4-D (610 $\left.\mathrm{kg} \mathrm{ha}^{-1}\right)$ and dicamba plus 2,4-D (590 kg ha-1) yielded similar grass biomass at that growth stage. Picloram and clopyralid plus 2,4-D yielded highest bio-

Table. 4. Means squares generated from analysis of variance of biomass data.

\begin{tabular}{lccc}
\hline \hline & & \multicolumn{2}{c}{ Mean square } \\
\cline { 3 - 4 } Source & Dissoula & Avon \\
Rep & 2 & Biomass & Biomass \\
Herb & 3 & 4077739.0 & 548844.2 \\
Stage & 4 & $3999166.9 * *^{\mathrm{a}}$ & $5139628.9 *$ \\
Herb $*$ Stage & 12 & $565234.1 * *$ & 216856.2 \\
Error & 38 & $148020.1 * *$ & 132272.3 \\
\hline
\end{tabular}

${ }^{\text {a.* }}$ significant at the $5 \%$ and $1 \%$ levels of probability, respectively. 


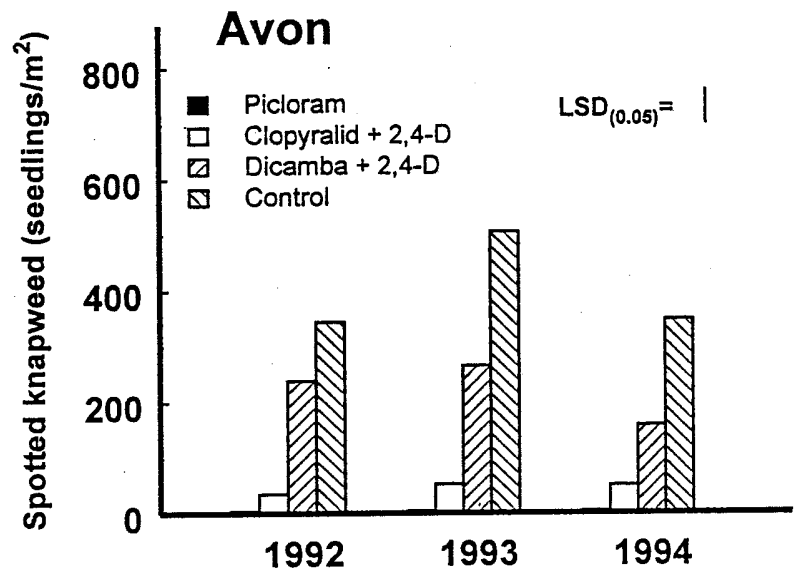

Fig. 6. Effect of herbicides each year following application on spotted knapweed seedlings at Avon.

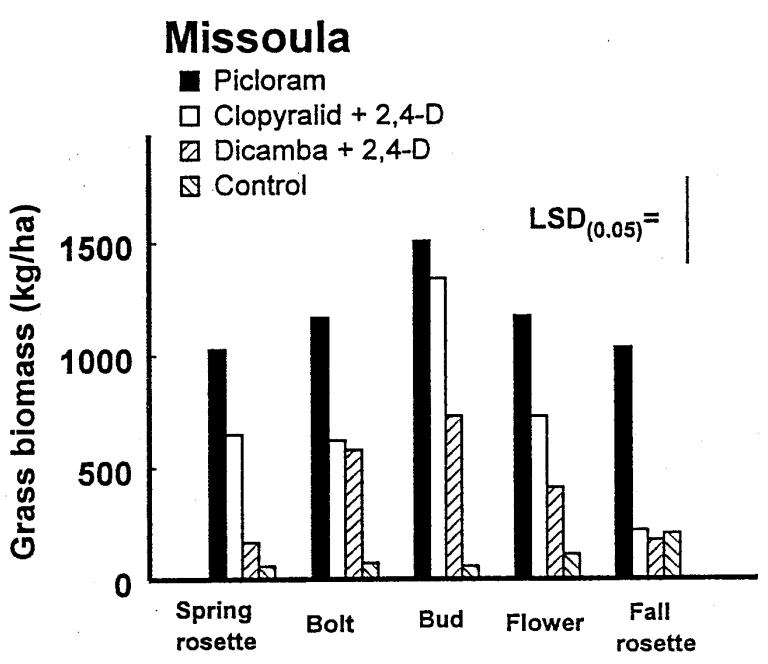

Fig. 7. Effect of herbicides applied at 5 growth stages on perennial grass biomass at Missoula. mass, but was similar to picloram applied at the bolt and flower growth stages. Dicamba plus 2,4-D applied at the bud growth stage yielded about $750 \mathrm{~kg} / \mathrm{ha}^{-1}$ of grass, which was about 10 times that of the control. Picloram and clopyralid plus 2,4-D yielded highest grass biomass when applied at the flower growth stage; however, clopyralid plus 2,4-D yielded grass biomass similar to that of dicamba plus 2,4-D at this growth stage. Dicamba plus 2,4-D did not increase grass yields over those of the control. Applied at the fallrosette growth stage, picloram yielded highest grass biomass. All other herbicide treatments were similar to the control when applied at this stage.

Herbicide treatments affected grass biomass at Avon and was not dependent upon growth stage (Table 4). Picloram, clopyralid plus 2,4-D, and dicamba plus 2,4-D yielded 1600,1175 , and $620 \mathrm{~kg} \mathrm{ha}^{-1}$ of grass biomass, respectively (Fig. 8). All herbicide treatments produced greater biomass than that of the control.

\section{Discussion}

Picloram provides consistent and effective control of spotted knapweed. Davis (1990) found that picloram applied at $0.07,0.11,0.14,0.22,0.25$, and $0.28 \mathrm{~kg}$ ai $\mathrm{ha}^{-1}$ during the bud growth stage provided $100 \%$ control for 3 to 5 years. In this 4 year study, we found that the efficacy and persistence of spotted knapweed control using picloram at $0.28 \mathrm{~kg}^{\mathrm{ai} \mathrm{ha}} \mathrm{ha}^{-1}$ was independent of the weeds growth stage and the time of application. Based on our study, we concluded that spotted knapweed reestablishes from its seedbank, rather than regrowth from mature plants. Spotted knapweed seeds remain dormant, but viable in the soil for over 8 years (Davis et al. 1993).

In many situations, land managers apply picloram when they notice the flowering plants. Unfortunately, this may be the least effective method of determining timing of herbicide applications. In this case, knapweed plants continue to produce seeds after picloram has been applied, but before the plants die. This replenishes the seedbank and results in continuous, periodic picloram applications, which are probably not cost effective (Griffith and Lacey 1991). Applying picloram before flowers appear may prevent spotted knapweed seed rain and reduce the seedbank. Over a long period (>10 years), spotted knapweed density may be reduced to occasional plants or patches, which can be retreated by spot spraying. An alternative method for determining timing of repeated application would be to identify threshold levels of spotted knapweed that would optimize the value of the application based of the response of the desired plant community.

Clopyralid plus 2,4-D $\left(0.21 \mathrm{~kg}^{2}\right.$ ai ha-1 plus 1.12 $\mathrm{kg}$ ai ha ${ }^{-1}$ ) applied at the bolt or bud stage provided control of spotted knapweed similar to picloram (about $95 \%$ control) at Avon and about 50\% control 3 years after application at Missoula. Fay (1990) found clopyralid plus 2,4-D at similar rates provided nearly $100 \%$ control of spotted knapweed 1 year following application on 2 sites in Montana. Clopyralid has a shorter soil residue period and adsorbs to soil particles more tightly than picloram (Fay et al. 1991). In addition, clopyralid plus 2,4-D may maintain greater species diversity than picloram (Rice et al. 1992). Therefore, clopyralid plus 2,4-D may provide an alternative to picloram in environmentally sensitive areas.

Dicamba is more effective in controlling spotted knapweed than 2,4-D because it provides 2 to 3 years of control depending on the level of plant competition following treatment (Fay et al. 1989). In another study, dicamba at $2.2 \mathrm{~kg}$ ai ha ${ }^{-1}$ provided excellent control when applied in the rosette growth stage (Lacey et al. 1986). In our study, dicamba plus $2,4-\mathrm{D}$ ( 0.56 plus $1.12 \mathrm{~kg}$ ai ha ${ }^{-1}$ ) was most effective when applied during bolt and bud growth stages, and least effective during the spring-and fall-rosette growth stage. However, clopyralid plus 2,4-D provided greater control

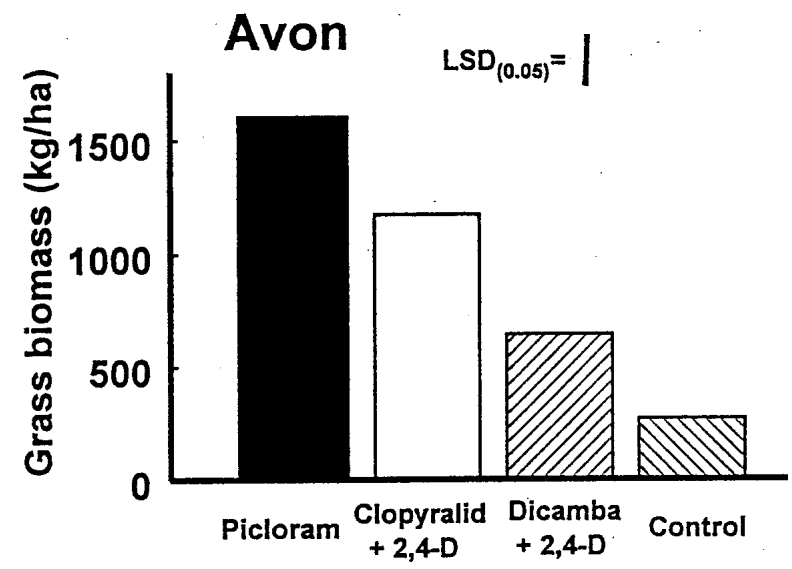

Fig. 8. Effect of herbicides on grass biomass at Avon. 
than dicamba plus 2,4-D at those stages. Dicamba plus 2,4-D is currently recommended for controlling spotted knapweed on small ranchettes (about 44 ha) because the combination provides good control, but is not persistent enough to limit landowners' options in the future (Fay et al. 1995). This study suggests that clopyralid plus 2,4-D may provide more effective and longer-term spotted knapweed control without greatly limiting future land management options.

Although picloram persists in the soil and affects weeds for 12 to 30 months (Hamaker et al. 1967, Lacey 1985), extended control is enhanced by competition from residual perennial grasses that are released from competition by the herbicide application (Renney and Hughes 1969). In most cases, picloram yielded highest grass biomass 3 years after treatment, which may help explain the persistence of control of spotted knapweed using this herbicide. Picloram increased grass biomass by 1,000 to $1,550 \mathrm{~kg} \mathrm{ha}^{-1}$. These results were similar to those found by Davis (1990) and Sheley and Jacobs (1997). Long-term herbicidal control of spotted knapweed using picloram can be cost-effective on cattle ranches with highly productive rangeland and a residual (suppressed) grass understory (Griffith and Lacey 1991). However, future research should focus on incorporating picloram and other herbicides into effective and sustainable integrated weed management strategies.

\section{Literature Cited}

Bedunah, D. and J. Carpenter. 1989. Plant community response following spotted knapweed (Centaurea maculosa) control on three elk winter ranges in western Montana. Knapweed Symp. Proc., Plant and Soil Sci. Dep. and Ext. Serv., Montana State Univ., Bull. 45. p. 205-212.

Bucher, R. F. 1984. Potential spread and cost of spotted knapweed on range. Montana State Univ. Ext. Serv., MontGuide MT8423AG.

Cuda, J. R., B. W. Sindelar, and J. H. Cardellina. 1989. Proposal for an integrated management system for spotted knapweed (Centaurea maculosa Lam.). pp 197-202. In: P. K. Fay and J. R. Lacey (eds.), Knapweed Symp. Proc. Montana State Univ., Bozeman, Mont.

Davis, E. S. 1990. Spotted knapweed (Centaurea maculosa Lam.) seed longevity, chemical control, and seed morphology. M. S. Thesis, Montana State Univ., Bozeman, Mont. 109 p.
Davis, E. S., P. K. Fay, T. K. Chicoine, and C. A. Lacey. 1993. Persistence of spotted knapweed. Weed Sci. 41:57-61.

Fay, P. K. 1990. Spotted knapweed control with Curtail®. 275 pp. In: P. K. Fay, E. S. Davis, and B. S. Mullen (eds). Weed control research. Agri. Exp. Sta. Res. Summary. Montana State Univ., Bozeman, Mont.

Fay, P. K., E. S. Davis, T. B. Chicoine, and C. A. Lacey. 1989. The status of long term chemical control of spotted knapweed. $45 \mathrm{p}$. In: P. K. Fay and J. R. Lacey (eds). Knapweed Symp. Proc., Plant and Soil Sci. and Ext. Serv., Montana State Univ. Bull.

Fay, P. K., E. S. Davis, C. A. Lacey, and T. K. Chicoine. 1991. Chemical control of Centaurea maculosa in Montana. 466 p. In: L. F. James, J. O. Evans, M. H. Ralphs, and R. D. Childs (eds). Noxious Range Weeds. Westview Press, Inc. Boulder, Colo.

Fay, P, T. Whitson, S. Dewey, and R. Sheley (eds/authors). 1995. 1995-96 Montana-Utah-Wyoming Weed Management Handbook. Montana State Univ. Ext. Serv. Bull. EB23. 245 pp.

Forcella, F., and S. J. Harvey. 1983. Eurasian weed infestation in western Montana in relation to vegetation and disturbance. Madrono 30:102-109.

Griffith, D., and J. R. Lacey. 1991. Economic evaluation of spotted knapweed [Centaurea maculosa] control using picloram. J. Range Manage. 44: 43-47.

Hamaker, J. W., C. R. Youngson, and G. A. Goring. 1967. Predictions of the persistence and activity of Tordon herbicide in soils under field conditions. Down to Earth. 23:30-36.

Harris P. and R. Cranston. 1979. An economic evaluation of control methods for diffuse and spotted knapweed in western Canada. Can. J. Plant Sci. 59:375-382.

Hirsch, S. A. and J. A. Leitch. 1996. The impact of knapweed on Montana's economy. Agr. Econ. Rep. No. 355. North Dakota State. Univ., Fargo, N.D. 44 p.

Lacey, C. A. 1985. A weed education program, and the biology and control of spotted knapweed (Centaurea maculosa Lam.) in Montana. M.S. Thesis, Montana State Univ., Bozeman, Mont. 179 p.

Lacey, C. 1989. Knapweed management: a decade of change. Knapweed Symp. Proc., Plant and Soil Sci. Dept. and Ext. Serv., Montana State Univ., Bull. 45. p. 1-6.

Lacey, J. R., K. M. Olson-Rutz, M. R. Haferkamp, and G. A. Kennett. 1994. Effects of defoliation and competition on total nonstructural carbohydrates of spotted knapweed (Centaurea maculosa). J. Range Manage. 47:481-484.

Lacey, C. A., J. R. Lacey, T. K. Chicoine, R. K. Fay, and R. A. French. 1986. Circ. Montana State Univ. Coopr. Ext. Serv., Bozeman, MT. 2 p.

Lacey, C. A., J. R. Lacey, P. K. Fay, J. M. Story, and D. L. Zamora. 1992. Controlling knapweed on Montana rangeland. Montana State Univ. Ext. Serv. Circ. 311. 15 p.
Losensky, B. J. 1987. An evaluation of noxious weeds on the Lolo, Bitterroot and Flathead Forest with recommendations for implementing a weed control program. USDA, Forest Service, Lolo Natl. Forest, Missoula, Mont. 64p.

Lym, R. G. and C. G. Messersmith. 1983. Control of leafy spurge with herbicides. North Dakota Farm Research. 40(5):16-19.

Lym, R. G. and C.G. Messersmith. 1986. Russian and spotted knapweed control by several herbicides in North Dakota. Western Soc. Weed Sci. Res. Prog. Rep. p. 6-7.

Olson, B. E., R. T. Wallander, and J. R. Lacey. 1997. Effects of sheep grazing on a spotted knapweed-infested Idaho fescue community. J. Range Manage. 50:386-390.

Peterson, R. G. 1985. Design and analysis of experiments. Marcel Dekker, Inc., New York, N.Y. 283 p.

Renney, A. J. and E. C. Hughes. 1969. Control of knapweed, Centaurea species in British Columbia with Tordon herbicides. Down to Earth 24:6-8.

Rice, P. M., D. J. Bedunah, and C. E. Carlson. 1992. Plant community diversity after herbicide control of spotted knapweed. USDA, Forest Serv. Intermountain Res. Sta., INT-460. $6 \mathrm{p}$

Roché, B. F., Jr. and C. J. Talbott. 1986. The collection history of Centaureas found in Washington State. Agr. Res. Cent., Washington State Univ. Res. Bull. XB0978. $35 \mathrm{p}$.

Roché, B. F., Jr., G. L. Piper, and C. J. Talbott. 1986. Knapweeds of Washington. Coop. Ext. Coll. of Agric. and Home Econ., Washington State Univ. EB1393.

Sheley, R. L. and J. S. Jacobs. 1997. Response of spotted knapweed and grass to picloram and fertilizer combinations. J. Range Manage. 50:263-297.

Sheley, R. L. T. J. Svejcar, and B. D. Maxwell. 1996. A theoretical framework for developing successional weed management strategies on rangeland. Weed Technol. 10:712-720.

Story, J. M. 1992. Biological control of weeds: selective, economical and safe. West. Wildlands. 18:18-23.

Tyser, R. W. and C. W. Key. 1988. Spotted knapweed in natural area fescue grasslands: an ecological assessment. Northwest. Sci. 62(4): 151-160.

Watson, A. K., and A. J. Renney. 1974. The biology of Canadian weeds. 6. Centaurea dif fusa and c. maculosa. Can. J. Plant Sci. 54:687-701.

Whitson, T. D., R. J. Swearingen, J. Baker, and R. D. Cunningham. 1993. Russian knapweed control at various growth stages. Western Soc. Weed Sci. Res. Prog. Rep. p. 41-42.

Whitson, T. D., R. Costa, and S. Campbell. 1986. Evaluation of various herbicide application times and treatments for control of knapweed spp. Western Soc. Weed Sci. Res. Prog. Rep. p. 26-27. 


\title{
Residual nitrogen effects on soil, forage, and steer gain
}

\author{
WILLIAM A. BERG AND PHILLIP L. SIMS
}

Authors are soil scientist and rangeland scientist, respectively, at the USDA-ARS Southern Plains Range Research Station, 2000 18th Street, Woodward, Okla. 73801.

\section{Abstract}

Nitrogen fertilization is a common practice on introduced grass pastures established on marginal farmland in the Southern Great Plains. The efficiency of $\mathbf{N}$ fertilizer use on pastures and concern about nitrate movement into substrata prompted this study of residual $\mathbf{N}$ effects following fertilization. The study was conducted on Old World bluestem (Bothriochloa ischaemum L.) pastures on Pratt soil (sandy, mixed thermic Psammentic Haplustalfs) in western Oklahoma where the 57-year average annual precipitation is $566 \mathrm{~mm} \mathrm{yr}^{-1}$. Herbage production and steer gains were quantified over 3 summer grazing seasons on paddocks fertilized annually with $0,34,68$, or $102 \mathrm{~kg} \mathrm{~N} \mathrm{ha}^{-1} \mathrm{yr}^{-1}$ during the preceding 5 years. Peak standing ungrazed herbage yields were 2 - to 4 -fold greater in paddocks fertilized the preceding 5 years and were linearly related to the total $\mathrm{N}$ applied the previous 5 years. Steer weight gain responded linearly to $N$ with an average of $0.63 \mathrm{~kg}$ gain over 3 years per $\mathrm{kg} \mathrm{N}$ applied over the preceding 5 years. No differences $(P>0.05)$ in soil nitrate concentrations to a depth of $2.8 \mathrm{~m}$ were measured among the $\mathrm{N}$ rate treatments. Overall, substantial effects of residual $N$ were measured in both herbage mass and steer weight gain for 3 years following 5 years of $N$ fertilization.

Key Words: Southern Plains, marginal farmland, grass fertilization, Old World bluestem, Bothriochloa ischaemum, forage quality

Nitrogen $(\mathrm{N})$ fertilization of introduced grass pastures is a common practice in western Oklahoma and adjacent areas in Texas (Dahl and Cotter 1984, Berg and Sims 1995). These pastures are usually established on marginal farmland that are deficient in plant-available $\mathrm{N}$ as a result of up to 100 years of cultivation and subsequent erosion (Haas et al. 1957). Management of $\mathrm{N}$ fertilized pastures requires a balance among production, profit, and environmental quality (Bock and Hergert 1991).

A single application of $68 \mathrm{~kg} \mathrm{~N} \mathrm{ha}^{-1} \mathrm{yr}^{-1}$ in April to WW Spar Old World bluestem (Bothriochloa ischaemum L.) pastures in western Oklahoma generally resulted in maximum forage mass and steer weight gain (Berg and Sims 1995). However, fertilizer

The authors thank the Agricultural Research Technicians and other support personnel at the Southern Plains Experimental Range, and Tom Popham for statistical analysis, and Sherry Dewald for manuscript processing.

All programs and services of the U. S. Department of Agriculture are offered on a nondiscriminatory basis without regard to race, color, national origin, religion, sex, age, marital status, or handicap.

Names are necessary to report factually on available data; however, the USDA neither guarantees nor warrants the standard of the product, and the use of the name by USDA implies no approval of the product to the exclusion of others that may also be suitable.

Manuscript accepted 3 July 1999.

\section{Resumen}

La fertilización nitrogenada es una práctica común en las praderas de pastos introducidos establecidas en las tierras agrícolas marginales de las Grandes Planicies del Sudeste. La eficiencia del uso de fertilizante nitrogenado en praderas y la preocupación acerca del movimiento de los nitratos hacia el substrato motivo la realización de este estudio de los efectos del nitrógeno residual seguido de la fertilización. Este estudio se condujo en praderas de "Old World Bluestem" (Bothriocloa aschaemum L.) en suelo Pratt (sandy, mixed thermic, Psemmentic Haplustalfs) localizadas en el oeste de Oklahoma, en donde el promedio de precipitación

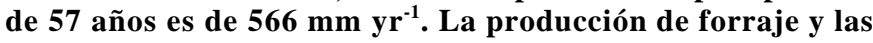
ganancias de los novillos se cuantificaron en 3 estaciones de apacentamiento en verano en potreros que habían fertilizado

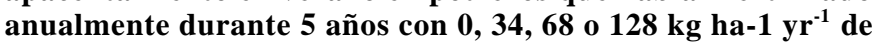
nitrógeno. Los rendimientos máximos de producción del forraje sin apacentar fue de 2 a 4 veces mayor en los potreros fertilizados durante los 5 años previos y estuvieron linealmente relacionados con la cantidad total de nitrógeno aplicado en los 5 años. Las ganancias de peso de los novillos respondieron linealmente a la aplicación de nitrógeno con un promedio en 3 años $0.63 \mathrm{~kg}$ de ganancia por kg de nitrógeno aplicado en los 5 años anteriores. No se encontraron diferencias $(P>0.05)$ entre tratamientos de nitrógeno con respecto en las concentraciones de nitratos medidas hasta una profundidad de $2.8 \mathrm{~m}$. En general, se midieron efectos substanciales del nitrógeno residual tanto en la producción de forraje como las ganancias de peso de los novillos durante 3 los tres años posteriores a 5 años de fertilización nitrogenada.

$\mathrm{N}$-use efficiency in steer weight gain was greater for a lower $\mathrm{N}$ application rate of $34 \mathrm{~kg} \mathrm{~N} \mathrm{ha}^{-1} \mathrm{yr}^{-1}$. Fertilizer $\mathrm{N}$-use efficiency averaged $3.3 \mathrm{~kg}$ steer weight gain per $\mathrm{kg} \mathrm{N}$ applied with the first $34 \mathrm{~kg} \mathrm{~N} \mathrm{ha}^{-1} \mathrm{yr}^{-1}$ increment, $1.0 \mathrm{~kg}$ for the second $34 \mathrm{~kg} \mathrm{~N}^{-1} \mathrm{yr}^{-}$ 1 increment (total of $68 \mathrm{~kg} \mathrm{~N} \mathrm{ha}^{-1} \mathrm{yr}^{-1}$ ) and was negligible for the third $34 \mathrm{~kg} \mathrm{~N} \mathrm{ha}^{-1} \mathrm{yr}^{-1}$ increment (total of $102 \mathrm{~kg} \mathrm{~N} \mathrm{ha}^{-1} \mathrm{yr}^{-1}$ ).

This study is a continuation of an earlier $\mathrm{N}$ rate study reported by Berg and Sims (1995). The objectives of the present study were to determine the residual $\mathrm{N}$ effects after 5 years of pasture fertilization on: 1) concentrations of nitrate, ammonium, total $\mathrm{N}$ and organic $\mathrm{C}$ in the soil; and 2) herbage mass, forage nutritive value, and steer weight gain in the ensuing 3 years without fertilization.

\section{Materials and Methods}

This study was conducted on the Southern Plains Experimental Range near Fort Supply $\left(99^{\circ} 23^{\prime} \mathrm{W}, 36^{\circ} 27^{\prime} \mathrm{N}\right)$ in western Oklahoma. Soils are predominately a deep loamy sand (Pratt series-sandy, 
mixed, thermic Psammentic Haplustalfs). Prior to cultivation, the land supported a sand sagebrush (Artemisia filifolia Torr.)mixed grass prairie with sand bluestem (Andropogon hallii Hack.), sand dropseed (Sporobolus cryptandrus (Torr.) Gray), blue grama (Bouteloua gracilis (H.B.K.)Lag.), switchgrass (Panicum virgatum L.), and little bluestem (Schizachyrium scoparium (Michx.) Nash) as dominant grasses (Berg 1994).

The study area was farmed for about 40 years before 'WW-Spar' Old World bluestem was established in the early 1980's. The bluestem pasture was fertilized with $68 \mathrm{~kg} \mathrm{~N} \mathrm{ha}^{-1} \mathrm{yr}^{-1}$ and grazed in 1986 and 1987. In 1988 the pasture was divided into 16 paddocks and ammonium nitrate treatments of $0,34,68$, and $102 \mathrm{~kg} \mathrm{~N}^{-1}$ $\mathrm{yr}^{-1}$ were broadcast applied in April of each year in a randomized complete block design with 4 replications. The $\mathrm{N}$ treatments were repeated for 5 years between 1988 and 1992 (Berg and Sims 1995). Incremental $\mathrm{N}$ rates were obtained by repeat applications of fertilizer, on the same day, with a drop spreader calibrated for the $34 \mathrm{~kg} \mathrm{~N} \mathrm{ha}^{-1} \mathrm{yr}^{-1}$ rate. Thus, the total amount of $\mathrm{N}$ applied over the 5-year period was $0,170,340$, and $510 \mathrm{~kg} \mathrm{~N}^{-1}$ for the respective annual $\mathrm{N}$ treatments. Paddocks were 1.2 ha for the control (no N) and 0.8 ha for each $\mathrm{N}$-fertilized treatment.

Paddocks were grazed 4 of the 5 years $\mathrm{N}$ fertilizer was applied (Berg and Sims 1995). A low temperature of -20 ${ }^{\circ} \mathrm{C}$ on $22 \mathrm{D}$ e c e m b e r 1989, following a dry fall (4 $\mathrm{mm}$ precipitation October through December 1989) resulted in extensive winterkill of WW-Spar Old World bluestem. To allow forage recovery, the bluestem pastures were not grazed during the 1990 growing season.

Soil sampling was designed to test differences among N-rate treatments following 5 years of $\mathrm{N}$ fertilization. Samples were taken in the spring of 1988 prior to $\mathrm{N}$ fertilization and again in the spring of 1993, approximately 1 year following the last application of $\mathrm{N}$ fertilizer. Two groups of soil samples were taken; the first was to characterize fertility in the surface $15 \mathrm{~cm}$ of soil, the second was to determine nitrate $\left(\mathrm{NO}_{3}\right)$ and ammonium $\left(\mathrm{NH}_{4}\right)$ movement and accumulation to a depth of $2.8 \mathrm{~m}$. Prior to soil sampling in 1988 and 1993, forage aftermath was burned in March. For the soil fertility sampling, because of soil heterogeneity within paddocks caused by topography and erosion, 3 representative $6 \times 10 \mathrm{~m}$ areas within each paddock were permanently marked and sampled in 1988 and resampled in 1993 . Twentyeight random $2-\mathrm{cm}$ diameter cores were taken to a depth of $15 \mathrm{~cm}$ in each $6 \times 10 \mathrm{~m}$ sampling area, composited by $5 \mathrm{~cm}$ increments, and air dried. Soil samples were passed through a $2 \mathrm{~mm}$ sieve to remove roots and foreign material prior to storage or analysis. Thus, 9 soil samples, composited from 28 subsamples, were collected in 1988 and again in 1993 for analyses from each paddock ( 3 areas x 3 depths). Data were averaged from the 3 areas (subsamples) per paddock for later statistical analyses. Nitrate was determined by $1 \mathrm{M}$ $\mathrm{KCl}$ extraction and $\mathrm{Cd}$ reduction (Gelderman and Fixen 1988), extractable ammonium by $1 \mathrm{M} \mathrm{KCl}$ extraction and the indophenol blue method (Keeny and Nelson 1982), total $\mathrm{N}$ by a Kjeldahl procedure (Bremner and Breitenbeck 1983), and organic $\mathrm{C}$ by the Mebius method (Nelson and Sommers 1982). Soil samples were air dried and stored in a cool, dry area and all analyses made in 1994.

Nitrate and ammonium concentrations to a depth of $2.8 \mathrm{~m}$ were determined in 4$\mathrm{cm}$ diameter soil cores taken at increments of 0-0.4, 0.4-1.2, 1.2-2.0., and 2.0-2.8 m. One core was taken per paddock in 1988 , the location marked, and another core taken in 1993 within $0.5 \mathrm{~m}$ of the original location. Samples were air dried and nitrate and ammonium determined by methods given above.

Precipitation measured at the Southern Plains Experimental Range headquarters, about $1.5 \mathrm{~km}$ from the research site, was $459 \mathrm{~mm}$ in 1993, $480 \mathrm{~mm}$ in 1994, and $457 \mathrm{~mm}$ in 1995 (Table 1). The 57 year mean is $566 \mathrm{~mm} \mathrm{yr}^{-1}$. January through June precipitation was $257 \mathrm{~mm}$ in 1993, $201 \mathrm{~mm}$ in 1994, and $338 \mathrm{~mm}$ in 1995; the
57 year January through June precipitation mean is $290 \mathrm{~mm}$. Average annual precipitation for the previous 5 years, beginning in 1988 was 503, 679, 560, 409, and 503 $\mathrm{mm}$, respectively.

Peak standing herbage mass was harvested within five, $1.25 \times 4 \mathrm{~m}$ exclosures within each paddock on 15 July 1993, 28 June 1994, and 1 July 1995 . The exclosures were moved annually. Herbage was cut at a $7-\mathrm{cm}$ height with a Hegge sickle bar plot harvester on $1.25 \mathrm{X} 4 \mathrm{~m}$ areas within each exclosure, collected as one sample, and weighed. Herbage mass in each paddock was also cut at a $7-\mathrm{cm}$ height with a Hegge sickle bar plot harvester by randomly sampling five, $1.25 \mathrm{x}$ $4 \mathrm{~m}$ areas within each paddock at the time steers were placed in the paddocks, 3 weeks later, and when the steers were moved. Herbage subsamples, of approximately $300 \mathrm{~g}$ size, were collected and dried at $57^{\circ} \mathrm{C}$ to determine dry matter content. These dried samples were ground to pass a 1-mm screen and analyzed for $\mathrm{N}$ (Bremner and Breitenbeck 1983) and in vitro dry matter digestibility (Tilley and Terry 1963 as modified by White et al. 1981). Nitrogen concentration was multiplied by 6.25 to estimate crude protein.

In this monoculture pasture, herbage mass sampled to a stubble height of $7 \mathrm{~cm}$ was considered to approximate the available forage mass for the grazing animal. Thus, herbage allowance was calculated as the average herbage mass in each paddock within each sampling interval divided by the number of steers and steer weight $(\mathrm{kg})$ in the paddock over that period.

Yearling steers were placed in the paddocks in June when grass height was visually estimated to be between 15 and 20 $\mathrm{cm}$. Steers were grazing similar Old World bluestem forage prior to the beginning of this summer grazing study. Steers grazed Old World bluestem in this study at or near peak nutritive value and when grass growth rates were generally high until mid July or early August. Steers, crosses of Hereford or Angus with Simmental, Limousin, or Brahman, were implanted with $200 \mathrm{mg}$ progesterone and $20 \mathrm{mg}$

Table 1. Monthly precipitation $(\mathrm{mm})$ during the years of the study (1993-1995) compared to the 57-year mean at the Southern Plains Experimental Range, 1940-1989, Ft. Supply, Okla.

\begin{tabular}{|c|c|c|c|c|c|c|c|c|c|c|c|c|c|}
\hline YearJan. & Feb. & Mar. & Apr. & May & Jun. & Jul. & Aug. & Sep. & Oct. & Nov. & Dec. & Total & \\
\hline & --- & --- & --- & --- & -- & $\cdots$ & n) - - - & --- & $\cdots$ & $-\cdots$ & $\cdots$ & $\cdots$ & \\
\hline 1993 & 36 & 36 & 40 & 56 & 78 & 11 & 59 & 86 & 22 & 10 & 17 & 10 & 459 \\
\hline 1994 & 12 & 17 & 28 & 74 & 55 & 15 & 78 & 48 & 28 & 64 & 26 & 34 & 480 \\
\hline 1995 & 15 & 4 & 103 & 28 & 115 & 73 & 53 & 13 & 36 & 0 & 1 & 18 & 457 \\
\hline Mean & 21 & 19 & 57 & 53 & 83 & 33 & 63 & 49 & 29 & 25 & 15 & 21 & 465 \\
\hline 56-year & 14 & 24 & 40 & 46 & 90 & 76 & 71 & 64 & 52 & 42 & 28 & 21 & 566 \\
\hline
\end{tabular}


estradiol benzoate in May. Initial weights of the 56 steers used each year averaged $298 \pm 3(\mathrm{SE}) \mathrm{kg}$ in $1993,232 \pm 3 \mathrm{~kg}$ in 1994 , and $257 \pm 3 \mathrm{~kg}$ in 1995 . Steers were weighed on the morning they were placed in the paddocks, and the day after they were removed. All steer weights followed an 18 hour fast without feed or water.

The number of steers used during the first 3 weeks was based on experience from the earlier 5-year $\mathrm{N}$ fertilization study by Berg and Sims (1995) and from previous studies at the Southern Plains Experimental Range (Sims and Dewald 1982). Steer numbers were adjusted slightly for the second grazing interval in an attempt to maintain similar amounts of forage mass per steer in each paddock. Because of variation in herbage growth, the subsequent grazing level was not always precise. Thus, care must be exercised in interpreting average daily weight gain and gain ha-1. Steer weight gain per paddock was the experimental unit used in the statistical analysis (SAS Institute 1985).

Cattle were removed and the pastures allowed to regrow before fall dormancy. Number of continuous grazing days was 35,33 , and 42 days in 1993, 1994, and 1995, respectively. Aftermath was burned in March 1993, but mowed and dropped in place in March of 1994 and 1995.

Residual N fertilizer use efficiency was calculated for each year (1993-95) by subtracting steer weight gain $\mathrm{ha}^{-1} \mathrm{yr}^{-1}$ on the unfertilized paddocks from steer weight gain $\mathrm{ha}^{-1} \mathrm{yr}^{-1}$ on paddocks $\mathrm{N}$ fertilized over the 1988-1992 period and then dividing by the total amount of $\mathrm{N}$ applied over the 1988-1992 period.

For the soil analyses our major interest was 5 years differences (deltas between 1988 and 1993) as affected by $\mathrm{N}$ treatments; therefore, the delta values were used in statistical analyses. Soil sampling design was a randomized complete block with rate of $\mathrm{N}$ as the treatment variable. Observations were made at incremental depths vertically within treatments. The analysis of variance (AOV) model was a randomized complete block with a block effect, $\mathrm{N}$ rate effect and depths analyzed as a repeated factor, which allowed for adjustment for correlation between depths when testing for depths and the depth $\mathrm{x} N$ rate interaction effects. The significance levels for $\mathrm{N}$ rates were determined by $\mathrm{F}$ tests and significance levels for depth and the depth $\mathrm{x} \mathrm{N}$ rate interaction were determined by Kendall's Tau. Analysis of variance was conducted for steer weight gain $\mathrm{ha}^{-1}$ as affected by $\mathrm{N}$ rates over years and for each year; treatment effects were also partitioned into linear, quadratic, cubic, and residual components by year. Peak standing herbage mass for each year (1988-1994) was analyzed using a repeated measure, 2-way AOV with correction for correlation between successive years. The AOV was conducted for average daily steer gain (ADG) and forage nutritive components. Duncan's new multiple range test $(\mathrm{P}<0.05)$ was used to separate treatment effects on steer ADG. Statistical analyses was conducted using SAS Institute (1985) procedures.

\section{Results and Discussion}

\section{Soil $\mathbf{N}$ and $\mathbf{C}$}

In the soil fertility analyses of the surface $15 \mathrm{~cm}$, nitrate was low with no significant change $(\mathrm{P}>0.05)$ following 5 years of pasture fertilization compared to nonfertilization (Table 2). Ammonium concentration increased $(\mathrm{P}<0.01)$ with increased $\mathrm{N}$ application, however, overall ammonium concentrations were lower in 1993 than in 1988. Extractable mineral N (nitrate and ammonium) has been commonly used as a routine soil test for plantavailable $\mathrm{N}$ in cultivated soils (Dahnke and Johnson 1990). However, peak herbage standing mass (Fig. 1) indicated that substantially more $\mathrm{N}$ was available to plants in paddocks receiving higher $\mathrm{N}$ rates in the preceding 5 years. Thus, routine agricultural soil tests for extractable nitrate and ammonium appear to be of little to no value in predicting $\mathrm{N}$ availability to plants in these and similar pastures. An exception to this might be when excessive fertilizer $\mathrm{N}$ is applied. Soil incubation tests (Dahnke and Johnson 1990) however, may be useful for quantifying $\mathrm{N}$ which becomes available from mineralization of organic $\mathrm{N}$ in pastures.

Table 2. Soil nitrate, ammonium, total $\mathrm{N}$, and organic $\mathrm{C}$ concentrations to $15 \mathrm{~cm}$ soil depth before (1988) and after (1993) 5 years of $\mathrm{N}$ fertilization and grazing of an Old World bluestem at the Southern Plains Experiemental Range, Ft. Supply, Okla.

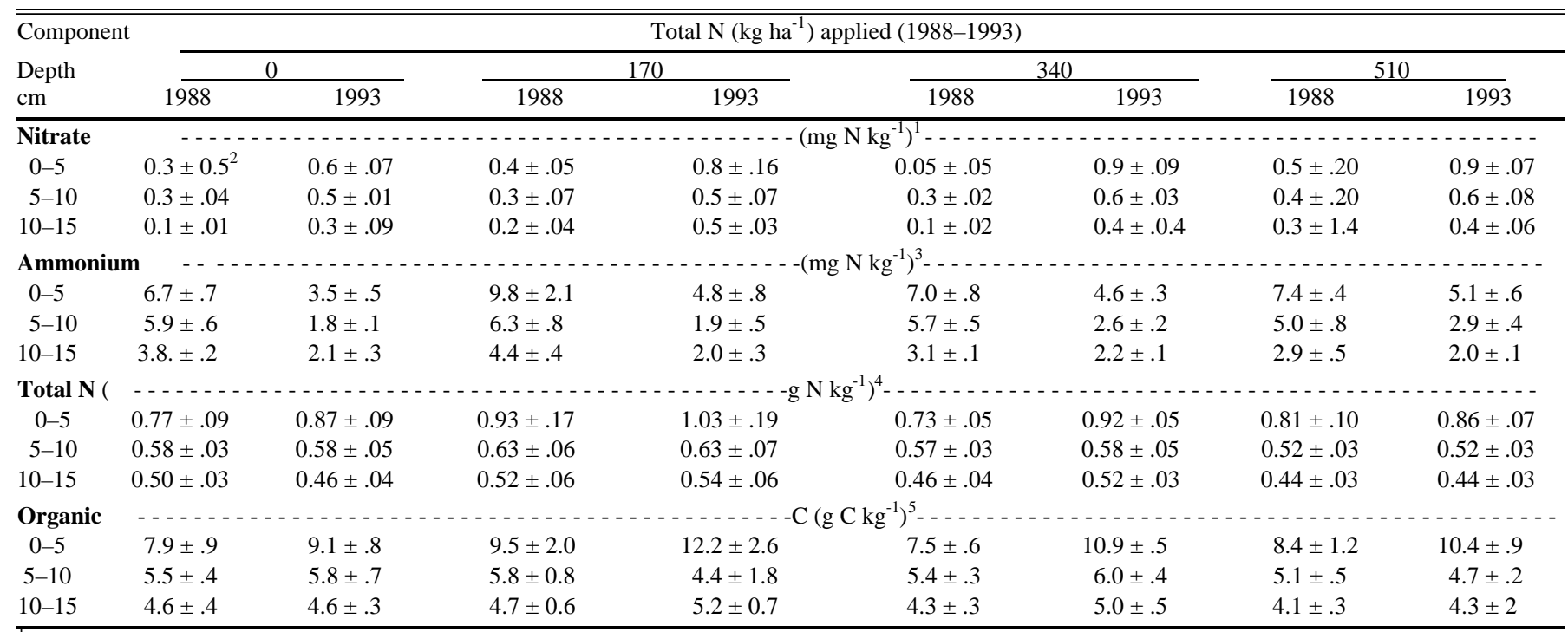

${ }_{\mathrm{P}}^{\mathrm{P}}>\mathrm{F}$ for differences in nitrate levels between years for $\mathrm{N}$ treatments $=0.85$, soil depths $=0.09$, and $\mathrm{N} \mathrm{X}$ soild depths $=0.98$.

${ }^{2}$ Standard error (s.e.), $\mathrm{n}=4$.

${ }^{3} \mathrm{P}>\mathrm{F}$ for differences in ammonium levels between years for $\mathrm{N}$ treatments $=0.01$, soil depths $=0.01$, and for $\mathrm{N} X$ soil depths $=0.87$.

${ }^{4} \mathrm{P}>\mathrm{F}$ for differences in total $\mathrm{N}$ levels between years for $\mathrm{N}$ treatments $=0.13$, soil depths $=0.01$, and for $\mathrm{N} \mathrm{X}$ soil depths $=0.68$. 


\section{Peak standing crop $\left(\mathrm{kg} \mathrm{ha}^{-1}\right)$}

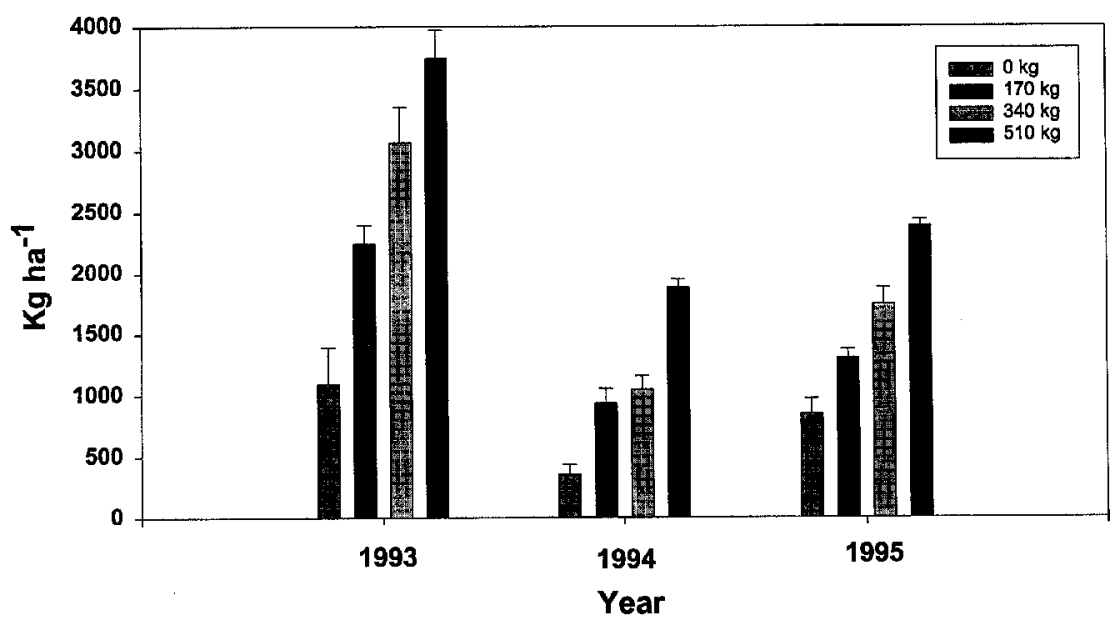

Fig. 1. Peak standing herbage mass $\left(\mathrm{kg} \mathrm{ha}^{-1} \pm\right.$ s.e. $)$ in 1993, 1994, and 1995 in exclosures within paddocks. Paddocks were fertilized with a total of $0,170,340$, and $510 \mathrm{~kg} \mathrm{~N} \mathrm{ha}^{-1}$ during the previous 5 years at the Southern Plains Experimental Range, Ft. Supply, Okla.

Total soil $\mathrm{N}$ and organic $\mathrm{C}$ concentrations increased in the surface $5 \mathrm{~cm}$ in all treatments over the 1988-1993 period. However, our major interest was whether or not there was a greater change in total $\mathrm{N}$ and organic $\mathrm{C}$ in the $\mathrm{N}$-fertilized paddocks than in the unfertilized paddocks. Thus, we calculated the change from 1988 to 1993 in total $\mathrm{N}$ and organic $\mathrm{C}$ for each $\mathrm{N}$ treatment and subjected the data to AOV. No significant change was measurable in total $\mathrm{N}(\mathrm{P}=0.13)$, but organic $\mathrm{C}$ increased $(\mathrm{P}=0.03)$ with increased $\mathrm{N}$ application (Table 2).

The potential for movement of mineral $\mathrm{N}$ into substrata and eventually into groundwater has been a concern with $\mathrm{N}$ fertilization of pastures. There was more $(\mathrm{P}<0.05)$ extractable nitrate in all treatments to a depth of $2.8 \mathrm{~m}$ in 1993 than in
1988 (Table 3). However, most levels of extractable nitrate, about $1 \mathrm{mg} \mathrm{N} \mathrm{kg}^{-1}$ soil ( 1 ppm extractable nitrate $\mathrm{N}$ ), were low. Higher nitrate concentrations were found at depths of 1.2 to $2.8 \mathrm{~m}$ in some soil samples from the higher $\mathrm{N}$ rate treatments; however, this was not consistent among replications and thus $\mathrm{N}$ treatments $\mathrm{X}$ depths interaction was not significant $(\mathrm{P}>$ $0.05)$. We believe that more intensive sampling is needed to quantify nitrate movement than the single adjacent soil cores we took per paddock in 1988 and 1993.

\section{Herbage dynamics}

Peak standing herbage yields from exclosures within paddocks that were $\mathrm{N}$ fertilized the preceding 5 years were 2- to 4-fold greater than yields from exclosures within paddocks that had not been fertilized (Fig. 1). There were significant differences $(P<0.01)$ in peak standing herbage yields between the $\mathrm{N}$ levels and years when residual $\mathrm{N}$ effects were measured. These differences were, however, not independent $(\mathrm{P}<0.05)$ because the relative difference in herbage mass and amount of $\mathrm{N}$ applied during the previous 5 years was not the same in all years, particularly in 1994 (Fig. 1). The increase was linearly related to total $\mathrm{N}$ applied with $\mathrm{r}^{2}$ values of 0.82 in 1993, 0.85 in 1994, and 0.90 in 1995 . This linear relationship indicated that $\mathrm{N}$ was a limiting factor in herbage mass yields on all residual $\mathrm{N}$ treatments each year the residual effect was measured. In contrast, yields of herbage mass during the 5 years that $\mathrm{N}$ was applied was curvilinearly related as increasing $\mathrm{N}$ fertilizer increments produced smaller increases in herbage mass (Berg and Sims 1995). Precipitation during the growing season for 1993, 1994, and 1995 was 185,172 , and $339 \mathrm{~mm}$, respectively (Table 1 ). The dynamics of peak standing herbage is a function of available $\mathrm{N}$ levels in the soil and recent precipitation. The separate effects on these 2 factors cannot be partitioned in this study. However, the relative responses from the $\mathrm{N}$ fertilizer treatments were consistent across all 3 years.

Available herbage mass per $100 \mathrm{~kg}$ steer $^{-1}$ weight averaged $60 \pm 3 \mathrm{~kg}$ across all treatments, grazing periods, and years (Table 4). There were no significant differences in the amounts of herbage mass per $100 \mathrm{~kg} \mathrm{steer}^{-1}$ between treatments within each period. Over the 3 years, herbage allowance averaged $139 \pm 15,170$ $\pm 20,133 \pm 14$, and $172 \pm 16 \mathrm{~kg}$ forage steer $^{-1}$ for the $0,170,340$, and $510 \mathrm{~kg}$ total $\mathrm{N} \mathrm{ha}^{-1}$ applied, respectively. There were

Table 3. Soil nitrate, ammonium concentrations to 2.8 msoil depth before (1988) and after (1993) 5 years of $\mathbf{N}$ fertilization and grazing of an Old World bluestem at the Southern Plains Experimental Range, Ft. Supply, Okla.

\begin{tabular}{|c|c|c|c|c|c|c|c|c|}
\hline \multirow{3}{*}{$\begin{array}{l}\text { Component } \\
\text { Depth } \\
\mathrm{m}\end{array}$} & \multicolumn{8}{|c|}{ Total N (kg ha $\left.{ }^{-1}\right)$ applied (1988-1993) } \\
\hline & \multicolumn{2}{|c|}{0} & \multicolumn{2}{|c|}{170} & \multicolumn{2}{|c|}{340} & \multicolumn{2}{|c|}{510} \\
\hline & 1988 & 1993 & 1988 & 1993 & 1988 & 1993 & 1988 & 1993 \\
\hline Nitrate & \multicolumn{8}{|c|}{ 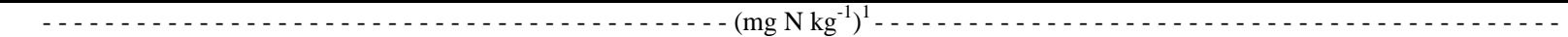 } \\
\hline $0-0.4$ & $0.3 \pm 0.1^{2}$ & $0.7 \pm .0 .1$ & $0.3 \pm 0.1$ & $0.9 \pm 0.1$ & $0.3 \pm 0.1$ & $1.0 \pm 0.2$ & $0.3 \pm 0.1$ & $1.0 \pm 0.1$ \\
\hline $.0 .4-1.2$ & $0.4 \pm 0.1$ & $0.7 \pm 0.1$ & $0.3 \pm .07$ & $05 . \pm .07$ & $0.3 \pm .02$ & $0.6 \pm .03$ & $0.4 \pm .20$ & $0.6 \pm .08$ \\
\hline $1.2-2.0$ & $0.3 \pm 0.1$ & $0.7 \pm 0.1$ & $0.5 \pm 0.2$ & $1.1 \pm 0.4$ & $0.3 \pm 0.1$ & $1.0 \pm 0.4$ & $0.3 \pm 0.1$ & $0.5 \pm 0.4$ \\
\hline $2.0-2.8$ & $0.6 \pm 0.1$ & $0.8 \pm 0.1$ & $0.9 \pm 0.3$ & $1.4 \pm 0.2$ & $0.9 \pm 0.3$ & $2.9 \pm 1.5$ & $0.3 \pm 1.6$ & $3.0 \pm 2.0$ \\
\hline \multicolumn{9}{|c|}{ Ammonium _. - } \\
\hline $0-0.4$ & $5.2 \pm 0.4$ & $2.4 \pm 0.3$ & $4.7 \pm 0.5$ & $2.5 \pm 0.2$ & $5.2 \pm 0.3$ & $2.6 \pm 0.1$ & $5.1 \pm 0.9$ & $2.7 \pm 0.3$ \\
\hline $0.4-1.2$ & $1.9 \pm 0.1$ & $2.0 \pm 0.4$ & $2.3 \pm 0.3$ & $2.0 \pm 0.4$ & $2.0 \pm 0.4$ & $1.5 \pm 0.2$ & $2.3 \pm 0.3$ & $1.8 \pm 0.6$ \\
\hline $1.2-2.0$ & $1.6 \pm 0.1$ & $1.2 \pm 0.2$ & $2.3 \pm 0.6$ & $1.9 \pm 0.3$ & $1.5 \pm 0.3$ & $1.0 \pm 0.2$ & $1.8 \pm 0.5$ & $3.0 \pm 1.2$ \\
\hline $2.0-2.8$ & $1.6 \pm 0.1$ & $1.5 \pm 0.2$ & $2.3 \pm 0.6$ & $2.1 \pm 0.6$ & $1.4 \pm 0.2$ & $1.9 \pm 0.2$ & $1.1 \pm 0.2$ & $.1 .5 \pm 0.2$ \\
\hline
\end{tabular}

${ }^{\mathrm{P}} \mathrm{P}>\mathrm{F}$ for differences in nitrate levels between years for $\mathrm{N}$ treatments $=0.21$, soil depths $=0.25$, and $\mathrm{N} \mathrm{X}$ soild depths $=0.27$.

${ }^{2}$ Standard error (s.e.), $\mathrm{n}=4$.

${ }^{3} \mathrm{P}>\mathrm{F}$ for differences in ammonium levels between years for $\mathrm{N}$ treatments $=0.52$, soil depths $=0.01$, and for $\mathrm{N} \mathrm{X}$ soil depths $=0.31$ 
Table 4. Stocking density and available herbage per $100 \mathrm{~kg}$ yearling $\operatorname{steer}^{-1}(\mathrm{~kg} \pm \mathrm{se})$ for 2 summer grazing periods to determine residual $\mathrm{N}$ effects over 3 years following 5 years of $N$ fertilization with $0,170,340$, and $570 \mathrm{~kg} \mathrm{~N} \mathrm{ha}^{-1}$ at the Southern Plains Experimental Range, Ft. Supply, Okla.

\begin{tabular}{|c|c|c|c|c|c|c|c|c|c|}
\hline \multirow[t]{2}{*}{ Year } & \multirow[t]{2}{*}{ Grazing Interval } & \multicolumn{6}{|c|}{ Total $\mathrm{N}\left(\mathrm{kg} \mathrm{ha}^{-1}\right)$ applied from 1988 to 1992} & \multirow{2}{*}{\multicolumn{2}{|c|}{510}} \\
\hline & & \multicolumn{2}{|c|}{0} & \multicolumn{2}{|c|}{170} & \multicolumn{2}{|c|}{340} & & \\
\hline 1993 & $\begin{array}{l}7 \text { June-29 June } \\
\text { 30 June-12 July }\end{array}$ & $\begin{array}{l}2.5 \\
2.3\end{array}$ & $\begin{array}{l}24 \pm 6 \\
43 \pm 9\end{array}$ & $\begin{array}{l}3.7 \\
3.1\end{array}$ & $\begin{array}{l}45 \pm 14 \\
84 \pm 28\end{array}$ & $\begin{array}{l}4.9 \\
4.3\end{array}$ & $\begin{array}{l}36 \pm 10 \\
54 \pm 14\end{array}$ & $\begin{array}{l}4.9 \\
4.9\end{array}$ & $\begin{array}{l}46 \pm 9 \\
63 \pm 16\end{array}$ \\
\hline 1994 & $\begin{array}{l}8 \text { June-27 June } \\
28 \text { June-11 July }\end{array}$ & $\begin{array}{l}2.5 \\
2.5\end{array}$ & $\begin{array}{l}61 \pm 4 \\
56 \pm 5\end{array}$ & $\begin{array}{l}3.7 \\
3.4\end{array}$ & $\begin{array}{l}79 \pm 11 \\
93 \pm 11\end{array}$ & $\begin{array}{l}4.9 \\
4.9\end{array}$ & $\begin{array}{l}70 \pm 9 \\
74 \pm 11\end{array}$ & $\begin{array}{l}4.9 \\
5.3\end{array}$ & $\begin{array}{r}91 \pm 6 \\
107 \pm 6\end{array}$ \\
\hline
\end{tabular}

significant differences in herbage mass, however, between the early and late grazing periods for treatments within years $(\mathrm{P}$ $<0.01)$ and between years $(\mathrm{P}<0.01)$. Averages for the early (June) and late (July) summer grazing periods were $57 \pm$ 4 and $64 \pm 3 \mathrm{~kg} 100 \mathrm{~kg} \mathrm{steer}^{-1}$, respectively. There were significant year effects $(\mathrm{P}<$ 0.01 ) for both the June and July periods; treatment effect was significant $(\mathrm{P}<0.05)$ only for the June grazing period. The treatment means for the June period were $48 \pm 7,59 \pm 11,51 \pm 25$, and $71 \pm 38 \mathrm{~kg}$ $100 \mathrm{~kg} \mathrm{steer}^{-1}$ for the $0,170,340$, and 510 $\mathrm{kg}$ total $\mathrm{N} \mathrm{ha}^{-1}$ applied, respectively. Although, there were no significant differences in herbage mass steer ${ }^{-1}$ between treatments within a grazing period, care is still needed in interpretation of the impacts on steer weight gains.

Forage crude protein concentration was considerably higher $(\mathrm{P}<0.05)$ on 7 June 1993, compared to 1994 and 1995, in paddocks that had received higher $\mathrm{N}$ rates in the preceding 5 years (Table 5). In contrast, on 7 June 1994 and on 19 June 1995 crude protein concentrations were relatively low and similar in all treatments. This may have resulted from sampling all herbage material above a $7 \mathrm{~cm}$ height rather than selectively grazed material. Crude protein was low in 1993 and 1994 on all treatments at the end of seasonal grazing. In contrast, crude protein was relatively high at the end of seasonal grazing in 1995 . We believe this is a reflection of increased soil $\mathrm{N}$ mineralization following favorable March through July 1995 precipitation (Table 1). When these pastures were fertilized during the previous 5 years, mid-summer crude protein levels averaged $5.3,6.3,7.2$, and 8.8 percent for the 0,34 , 68 , and $102 \mathrm{~kg} \mathrm{~N} \mathrm{ha}^{-1}$ treatments, respectively (Berg and Sims 1995). Thus, forage crude protein level is an early sign that $\mathrm{N}$ is limiting plant production.

In vitro dry matter digestibility (IVDMD) was higher $(\mathrm{P}<0.01)$ in June
1993 and 1994 on treatments that had received the higher $\mathrm{N}$ rates (Table 5). By the time steers were removed in mid July 1993 and 1994, IVDMD was lower (P < 0.05 ) on treatments that had received the higher $\mathrm{N}$ rates. This lower IVDMD was a reflection of a higher proportion of stems and mature seed heads in paddocks that had received the higher $\mathrm{N}$ rates. In contrast, few Old World bluestem plants produced seedheads in the $0 \mathrm{~N}$ treatment. We have observed a similar absence of Old World bluestem heading in 5 to 10 year old Old World bluestem Conservation Reserve Program (CRP) plantings on Ndeficient farmland. During the years of fertilization, IVDMD in early summer averaged 70 to 72 percent and 59 to 61 percent during the mid-July period (Berg and Sims 1995).

\section{Steer gains}

Steer average daily gain (ADG) in 1993 was greater $(\mathrm{P}<0.01)$ on the higher $\mathrm{N}$ treatments (Table 6), probably a reflection of higher crude protein concentration in forage (Table 5). Conversely, steer ADG in 1994 was relatively low on all treatments, again a reflection of low crude protein concentrations in forage. Steer ADG during 1995 averaged $0.89 \mathrm{~kg}$ steer $^{-1}$ day $^{-}$ 1 , apparently a reflection of higher forage protein concentrations later in the grazing season (Table 5).

Weight gains of steers during 1993-1995 increased linearly with increasing $\mathrm{N}$ rates applied during the preceding 5 years (Fig. 2). Over the 3 years, steer weight gain averaged $0.63 \mathrm{~kg}$ per $\mathrm{kg}$ $\mathrm{N}$ applied during the preceding 5 years. The value can also be calculated by averaging residual $\mathrm{N}$-use efficiency over 3 years for each $\mathrm{N}$ application rate from values of $0.59 \pm 0.29$ (se) $\mathrm{kg}$ steer weight gain per total $\mathrm{kg} \mathrm{N}$ applied for the $170 \mathrm{~kg}$ $\mathrm{N}$ application, $0.68 \pm 0.06 \mathrm{~kg}$ gain per $\mathrm{kg}$ $\mathrm{N}$ for the $340 \mathrm{~kg} \mathrm{~N}$ application, and $0.63 \pm$ $0.06 \mathrm{~kg}$ gain per $\mathrm{kg} \mathrm{N}$ for the $510 \mathrm{~kg} \mathrm{~N}$ application. Total steer weight gain averaged over the 3 residual grazing years was $185 \mathrm{~kg} \mathrm{ha}^{-1}$ for the $0 \mathrm{~N}$ application, $285 \mathrm{~kg}$ $\mathrm{ha}^{-1}$ for the $170 \mathrm{~kg} \mathrm{~N} \mathrm{ha}^{-1}$ application, 416

Table 5. Crude protein and in vitro dry matter digestibility of Old World bluestems at the beginning and end of seasonal grazing of paddocks fertilized annually for the total $\mathrm{N}$ applied $\left(\mathrm{kg} \mathrm{N} \mathrm{ha}^{-1}\right)$ during the preceding 5 years at the Southern Plains Experimental Range, Ft. Supply, Okla.

\begin{tabular}{lccccc}
\hline \hline & \multicolumn{5}{c}{ Total N applied $\left(\mathrm{kg} \mathrm{N} \mathrm{h}^{-1}\right)$} \\
\cline { 2 - 6 } Forage component & Date & 0 & 170 & 340 & 510 \\
\hline Crude protein & 7 June 1993 & $8.7^{\mathrm{c}}$ & $9.6^{\mathrm{c}}$ & $10.9^{\mathrm{b}}$ & $12.1^{\mathrm{a}}$ \\
& 15 July 1993 & $5.0^{\mathrm{a}}$ & $4.8^{\mathrm{a}}$ & $4.6^{\mathrm{a}}$ & $5.2^{\mathrm{a}}$ \\
& 7 June 1994 & $7.3^{\mathrm{a}}$ & $7.1^{\mathrm{a}}$ & $7.6^{\mathrm{a}}$ & $7.6^{\mathrm{a}}$ \\
& 14 July 1994 & $6.1^{\mathrm{a}}$ & $5.7^{\mathrm{a}}$ & $4.8^{\mathrm{b}}$ & $4.7^{\mathrm{b}}$ \\
& 19 June 1995 & $7.6^{\mathrm{a}}$ & $7.8^{\mathrm{a}}$ & $7.6^{\mathrm{a}}$ & $7.7^{\mathrm{a}}$ \\
1 Aug. 1995 & $6.6^{\mathrm{b}}$ & $7.1^{\mathrm{b}}$ & $7.9^{\mathrm{a}}$ & $6.8^{\mathrm{b}}$ \\
In vitro dry matter digestibility & & & & \\
& 7 June 1993 & $65.7^{\mathrm{c}}$ & $67.0^{\mathrm{bc}}$ & $68.4^{\mathrm{ab}}$ & $69.0^{\mathrm{a}}$ \\
& 15 July 1993 & $56.6^{\mathrm{a}}$ & $54.2^{\mathrm{a}}$ & $52.8^{\mathrm{b}}$ & $51.1^{\mathrm{c}}$ \\
7 June 1994 & $62.1^{\mathrm{b}}$ & $63.5^{\mathrm{a}}$ & $64.2^{\mathrm{a}}$ & $64.0^{\mathrm{a}}$ \\
& 14 July 1994 & $57.5^{\mathrm{a}}$ & $57.3 \mathrm{a}$ & $52.9^{\mathrm{b}}$ & $51.3^{\mathrm{b}}$ \\
19 June 1995 & $61.0^{\mathrm{a}}$ & $62.1^{\mathrm{a}}$ & $62.7^{\mathrm{a}}$ & $60.1^{\mathrm{a}}$ \\
1 Aug. 1995 & $56.6^{\mathrm{a}}$ & $57.4^{\mathrm{a}}$ & $54.3^{\mathrm{a}}$ & $52.9^{\mathrm{a}}$ \\
\hline
\end{tabular}

${ }^{1}$ Values within a date followed by a common superscript are not significantly different $(\mathrm{P}>0.05)$. 


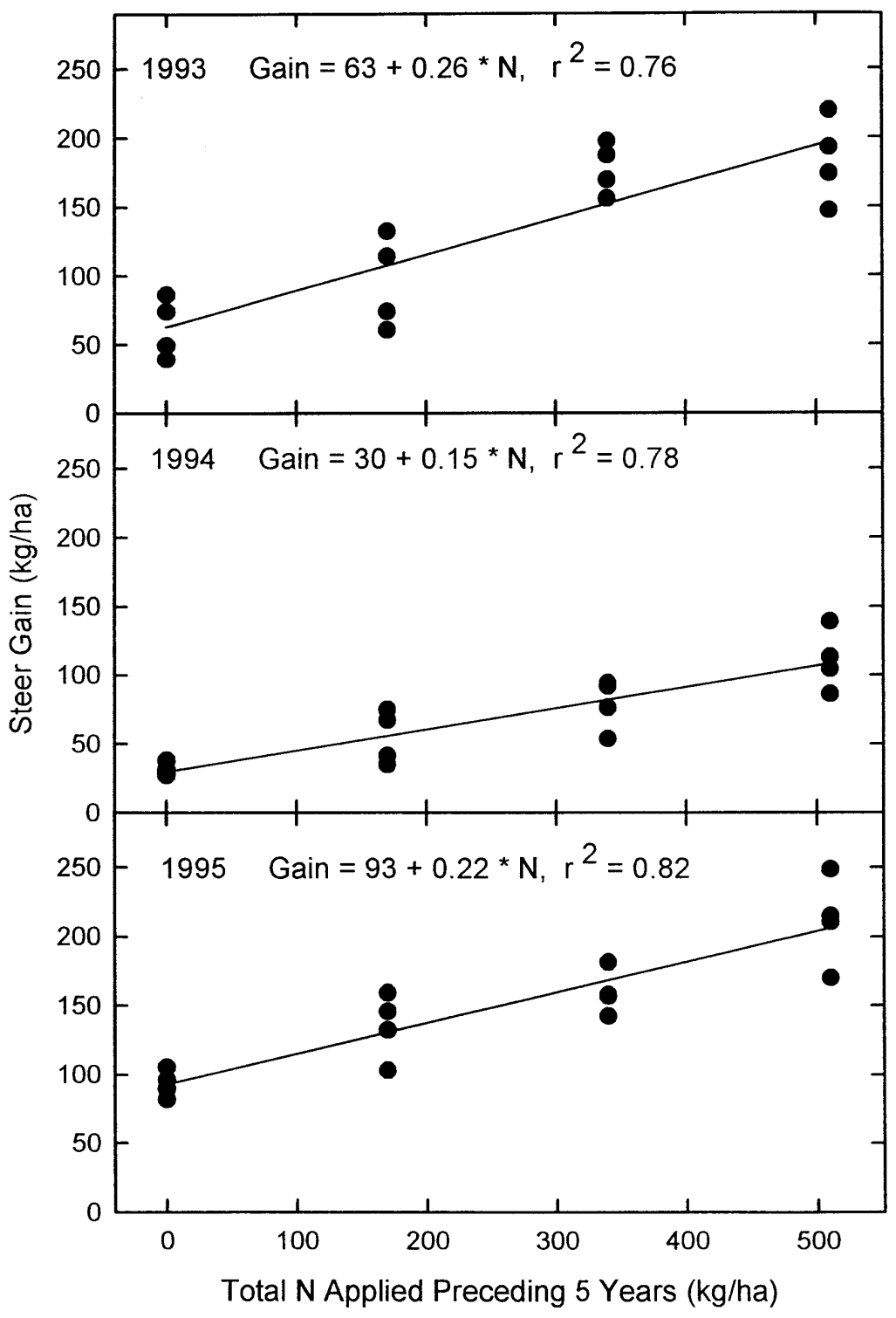

Fig. 2. Steer weight gain over 3 years as related to the total amount of $N$ applied the preceding 5 years at the Southern Plains Experimental Range, Ft. Supply, Okla.

$\mathrm{kg} \mathrm{ha}^{-1}$ for the $340 \mathrm{~kg} \mathrm{~N} \mathrm{ha}^{-1}$ application, and $505 \mathrm{~kg} \mathrm{ha}^{-1}$ for the $510 \mathrm{~kg} \mathrm{~N} \mathrm{ha}^{-1}$ application. We speculate that the residual $\mathrm{N}$ effect will be present, but diminish, over the next several years.

The residual $\mathrm{N}$-use efficiency averaging $0.63 \mathrm{~kg}$ steer weight gain per $\mathrm{kg} \mathrm{N}$ applied the preceding 5 years was additive to the fertilizer N-use efficiency previously reported (Berg and Sims 1995). A rigorous summation of fertilizer N-use efficiency during the years $\mathrm{N}$ was applied plus the residual effect was not appropriate since the study was $\mathrm{N}$ fertilized for 5 years and only grazed for 4 of these years. However, at the $34 \mathrm{~kg} \mathrm{~N}^{-1} \mathrm{yr}^{-1}$ rate, $\mathrm{N}$-use efficiency averaged $3.3 \mathrm{~kg}$ steer weight gain per $\mathrm{kg} \mathrm{N}$ applied over 4 years the pad- docks were $\mathrm{N}$ fertilized and grazed (Berg and Sims 1995) and the residual $\mathrm{N}$ effect reported here was an additional $0.59 \mathrm{~kg}$ steer weight gain per $\mathrm{kg} \mathrm{N}$ applied. Thus, the summation suggests a $\mathrm{N}$-use efficiency of about $3.9 \mathrm{~kg}$ steer weight gain per $\mathrm{kg} \mathrm{N}$ applied for the most efficient $\mathrm{N}$ application rate of $34 \mathrm{~kg} \mathrm{~N} \mathrm{ha}^{-1} \mathrm{yr}^{-1}$.

\section{Conclusions and management implications}

Annual $\mathrm{N}$ flux in rangeland is small in relation to the total $\mathrm{N}$ in soil, vegetation, and litter (Berg et al. 1997). The major $\mathrm{N}$ inputs in rangeland ecosystems are believed to be from atmospheric deposition and protein supplements fed to cattle. Primary outputs are ammonia volatilized from plant and animal wastes and livestock products sold (Woodmansee 1978, Lauenroth and Milchunas 1991). On native sandhills rangeland, 50 years of moderate grazing by cattle had no measurable effect on $\mathrm{C}$ and $\mathrm{N}$ concentrations in the surface $5 \mathrm{~cm}$ of the sandy soil or total $\mathrm{N}$ uptake by plants as compared with nongrazed areas (Berg et al. 1997). Fluxes of $\mathrm{N}$ in improved pastures would differ from those in rangeland in the amounts of $\mathrm{N}$ fertilizer applied and in the magnitude and distribution of livestock wastes distributed, protein supplements used, and products sold. An increase in total $\mathrm{N}$ averaging 5 to $8 \mathrm{~kg} \mathrm{ha}^{-1} \mathrm{yr}^{-1}$ over a 20 to 22 year period was found in $\mathrm{N}$-fertilized pastures as compared to adjacent unfertilized pastures in western Oklahoma (Berg 1988).

Nitrogen fertilization can result in soil acidification. Soil pH in the surface $5 \mathrm{~cm}$ was reduced from 6.7 to 5.3 by 20 years of $\mathrm{N}$ fertilization of improved pastures on loamy sand soils in Oklahoma (Berg 1986). In Kansas, 20 years of $67 \mathrm{~kg} \mathrm{~N}$ fertilization $\mathrm{ha}^{-1} \mathrm{yr}^{-1}$ decreased the surface $\mathrm{pH}$ of a silt loam soil under grass from 5.9 to 5.1 (Owensby et al. 1969). Generally, rangeland and grassland soils are not tillable and mixing lime to correct acidification may be difficult (Owensby and Launchbaugh 1971). Acidification of dryland grain-growing soils is an emerging problem in western North America (Mahler and Harder 1984, McCoy and Webster 1977, Westerman 1981). Plant species and selections within species vary in their sensitivity to acid soils. Foy (1984) found tall warm-season grasses were tolerant to $\mathrm{pH}$ of 4.5 to 5.0 while many legumes may be sensitive to acid soil at soil $\mathrm{pH}$ of 5.5 to 6.0 .

This study indicated that substantial residual $\mathrm{N}$ effects can be expected in forage and beef production for several years after 5 years of $\mathrm{N}$ application to Old World bluestem pastures established on marginal farmland in the Southern Plains. The 3-year residual $\mathrm{N}$ effect resulted in steer weight gain of about $0.6 \mathrm{~kg}$ per $\mathrm{kg} \mathrm{N}$ applied the preceding 5 years. At a custom grazing rate of about $\$ 0.55 \mathrm{~kg}^{-1}$ stocker weight gain, this represents an additional return of about $\$ 0.32$ per $\mathrm{kg}$ of $\mathrm{N}$ applied. Economic returns appeared to favor the 34 $\mathrm{kg} \mathrm{ha}^{-1} \mathrm{yr}^{-1}$ pasture fertilization rate. At a cost of $\$ 0.88 \mathrm{~kg}^{-1} \mathrm{~N}$ applied, the return was $\$ 1.80$ in steer weight gain (at the custom grazing rate) the year of application plus a potential $\$ 0.30$ in steer weight gain from the residual $\mathrm{N}$ effect. At higher $\mathrm{N}$ rates the return per unit of $\mathrm{N}$ applied is lower. 
Table 6. Average daily steer weight gains $\left(\mathrm{kg} \mathrm{steer}^{-1} \mathrm{day}^{-1}\right)$ and preliminary economic analysis of residual $\mathrm{N}$ effects on steer weight gains $\left(\mathrm{kg} \mathrm{steer}^{-1} \mathrm{day}^{-1}\right.$ and $\left.\mathrm{kg} \mathrm{ha}^{-1}\right)$ over 3 summer grazing periods on Old World bluestem paddocks fertlized annually at 4 rates of $\mathrm{N}$ applied $\left(\mathrm{kg} \mathrm{N} \mathrm{ha}^{-1}\right)$ during the preceding 5 years at the Southern Plains Experimental Range, Ft. Supply, Okla.

\begin{tabular}{|c|c|c|c|c|}
\hline \multirow{3}{*}{$\begin{array}{l}\text { Annual } \\
\text { Total 5-year }\end{array}$} & \multicolumn{4}{|c|}{$\mathrm{N}$ fertilization rate $\left(\mathrm{kg} \mathrm{N} \mathrm{kg}^{-1}\right)$} \\
\hline & 0 & 34 & 68 & 102 \\
\hline & 0 & 170 & 340 & 510 \\
\hline \multicolumn{5}{|c|}{ Average daily steer weight gains $\left(\mathrm{kg} \mathrm{steer}^{-1}\right.$ day $\left.^{-1}\right)$} \\
\hline 7 June-15 July 1993 & $0.67^{\mathrm{bl}}$ & $0.80^{\mathrm{b}}$ & $1.08^{\mathrm{a}}$ & $1.09^{\mathrm{a}}$ \\
\hline 7 June-14 July 1994 & $0.38^{\mathrm{b}}$ & $0.45^{\mathrm{b}}$ & $0.47^{\mathrm{b}}$ & $0.65^{\mathrm{a}}$ \\
\hline 19 June-1 Aug. 1995 & $0.89^{\mathrm{a}}$ & $0.85^{\mathrm{a}}$ & $0.83^{\mathrm{a}}$ & $1.00^{\mathrm{a}}$ \\
\hline \multicolumn{5}{|l|}{ Total steer gain } \\
\hline -3-year gain $\left(\mathrm{kg} \mathrm{ha}^{-1}\right)$ & 185 & 285 & 416 & 505 \\
\hline - Total $\mathrm{N}$ cost $\left(\$ 0.66 \mathrm{~kg}^{-1} \mathrm{~N}\right)$ & 0 & $\$ 112.20$ & $\$ 224.40$ & $\$ 336.60$ \\
\hline \multicolumn{5}{|l|}{ Economic component: } \\
\hline 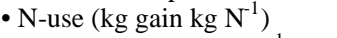 & Baseline & 0.59 & 0.68 & 0.63 \\
\hline - Additional gain $\left(\mathrm{kg} \mathrm{ha}^{-1}\right)$ & - & 100 & 231 & 320 \\
\hline \multicolumn{5}{|c|}{ Comparison based on steer ownership } \\
\hline - Value of gain $\left(\$ 1.10 \mathrm{~kg}^{-1}\right)$ & - & $\$ 110.00$ & $\$ 254.10$ & $\$ 352.00$ \\
\hline • Total sales $\left(\$ 1.10 \mathrm{~kg}^{-1}\right)$ & $\$ 203.50$ & $\$ 313.50$ & $\$ 457.60$ & $\$ 555.50$ \\
\hline - Sales less $N$ costs & $\$ 203.50$ & $\$ 201.30$ & $\$ 233.20$ & $\$ 218.90$ \\
\hline \multicolumn{5}{|c|}{ Comparison based on custom grazing rates: } \\
\hline - Custom rates $\left(\$ 0.55 \mathrm{~kg}^{-1}\right)$ & $\$ 101.75$ & $\$ 156.75$ & $\$ 228.80$ & $\$ 277.75$ \\
\hline - Return (Custom rate-N) & $\$ 101.75$ & $\$ 44.55$ & $\$ 4.40$ & $-\$ 58.85$ \\
\hline
\end{tabular}

${ }^{1}$ Steer weight gains within a year followed by a common superscript are not significantly different $(\mathrm{P}>0.05)$.

Preliminary economic returns to the resources used and to management have been estimated for both yearling stocker ownership and custom grazing rates (Table 6). Assuming all other costs are proportional, the $68 \mathrm{~kg} \mathrm{~N}$ ha rate yielded $\$ 233.20$ per ha for the 3 years of grazing pastures that were fertilized during the previous 5 years. The returns of all 4 fertilizer rates ranged between $\$ 203$ and $\$ 233$. Using a custom grazing rate of $\$ 0.55 \mathrm{~kg}^{-1}$, returns to fertilizer applied ranged from a low of $-\$ 58.85$ to a high of $\$ 101.75$ for the 3 year period. In this case, the unfertilized control had the highest return, followed by the 34 and $68 \mathrm{~kg} \mathrm{~N}^{-1}$ at $\$ 44.55$ and $\$ 4.40$, respectively. The 102 $\mathrm{kg} \mathrm{N} \mathrm{ha}^{-1}$ rate lost an estimated $\$ 58.85$ for the 3 years that residual $\mathrm{N}$ effects were measured. Additional economic analyses are needed to evaluate net returns for the 5 years of $\mathrm{N}$ fertilization plus the 3 years of residual $\mathrm{N}$ effects reported here.

\section{References}

Berg, W. A. 1986. Effect of 20 years of low N rate pasture fertilization on soil acidity. $\mathrm{J}$. Range Manage. 39:122-124.

Berg, W. A. 1988. Soil nitrogen accumulation in fertilized pastures of the Southern Plains. J. Range Manage. 41:22-25.

Berg, W. A. 1994. Sand sagebrush-mixed prairie. pp. 99. In: T. N. Shiflet (ed.) Rangeland cover types of the United States. SRM, Denver, Colo.
Berg, W. A. and P. L. Sims. 1995. Nitrogen fertilizer use efficiency in steer gain on Old World bluestem. J. Range Manage. 48:465-469.

Berg, W. A., J. A. Bradford, and P. L. Sims. 1997. Long-term soil nitrogen and vegetation change on sandhill rangeland. J. Range Manage. 50:482-486.

Bock, B. R. and G. W. Hergert. 1991. Fertilizer nitrogen management. p. 139-164. In R. F. Follett, D. R. Keeney, and R. M. Cruse (eds.). Managing nitrogen for ground water quality and farm profitability. Soil Sci. Soc. Amer. Madison, Wisc.

Bremner, J. M. and G. A. Breitenbeck. 1983. A simple method for determination of ammonium in semimicro-kjeldahl analysis of soils and plant materials using a block digester. Commun. Soil Sci. Plant Anal. 14:905-913.

Dahl, B. E. and P. F. Cotter. 1984. Management of weeping lovegrass in west Texas. Management Note 5. Dept. Range and Wildlife Mgt. Texas Tech Univer., Lubbock, Tex.

Dahnke, W. C. and G. V. Johnson. 1990. Testing soils for available nitrogen. p. 127139. In: R. L. Westerman (ed.) Soil testing and plant analysis. Soil Sci. Soc. Amer. Inc. Madison, Wis.

Foy, C. D. 1984. Physiological effects of hydrogen, aluminum, and manganese toxicities in acid soil. p. 57-97. In: F. Adams (ed) Soil Acidity and Liming, 2nd ed. Amer. Soc. Agron. Madison, Wisc.

Gelderman, R. H. and P. E. Fixen. 1988. Recommended nitrate-N tests. p. 10-12. In: Recommended Chemical Soil Test Procedures. North Dakota Agric. Exp. Sta. Bull 499. North Dakota Agric. Exp. Sta. Fargo, N.D.

Haas, H. J., C. E. Evans, and E. F. Miles. 1957. Nitrogen and carbon changes in Great
Plains soils as influenced by cropping and soil treatments. USDA Tech. Bull. 1164. U.S. Printing Office, Washington, D.C.

Keeny, D.R. and D.W. Nelson. 1982. Nitrogen-Inorganic forms. p. 643-698. In A. L. Page (ed.) Methods of soil analysis, Part 2. Amer. Soc. Agron. Madison, Wisc.

Lauenroth, W.K. and D.G. Milchunas. 1991. Short-grass steppe. p. 183-226. In: R. T.Coupland (ed.) Natural Grasslands: Introduction and Western Hemisphere, Ecosystems of the World. Vol. 8A, Elsevier, New York.

Mahler, R.H., and R.W. Harder. 1984. The influence of tillage methods, cropping sequence, and $\mathrm{N}$ rates on the acidification of a northern Idaho soil. Soil Sci.137:52-60.

McCoy, D.A., and G.R. Webster. 1977. Acidification of a luvisolic soil caused by low rate, long-term applications of fertilizers and its effects on growth of alfalfa. Can. J. Soil Sci. 57:119-127.

Nelson, D.W. and L.E. Sommers. 1982. Total carbon, organic carbon, and organic matter, p. 539-579. In: A. L. Page (ed.) Methods of soil analysis, Part 2. Amer. Soc. Agron. Madison, Wisc.

Owensby, C. E., and J. L. Launchbaugh. 1971. Acidifying nitrogen compounds and range fertilization. J. Range Manage. 24:203-206.

Owensby, C.E., K.L. Anderson, and D. A. Whitney. 1969. Some chemical properties of a silt loam soil after 20 years' nitrogen and phosphorus fertilization of smooth bromegrass (Bromus inermis Leyss.). Soil Sci. 108:24-29.

SAS Institute. 1985. SAS user's guide: Basics. SAS Institute. Cary, N.C.

Sims, P. L. and C. L. Dewald, 1982. Old World bluestems and their forage potential for the Southern Great Plains. A review of early studies. Agr. Res. Serv. Agr. Rev. Man., South. Series, No. 28. 15 p.

Tilley, J. M. A. and R. A. Terry. 1963. A two stage technique for the in vitro digestion of forage crops. J. Brit. Grassl. Soc. 18:104111.

Westerman, R. L. 1981. Factors affecting soil acidity. Solutions 25:64-81

White, L. M., G. P. Hartman, and J. W. Bergman. 1981. In vivo digestibility, crude protein, and phosphorus content of straw of winter wheat, spring wheat, barley, and oat cultivars in eastern Montana. Agron. J. 73:117-121.

Woodmansee, R. G. 1978. Additions and losses in nitrogen in grassland ecosystems. Bioscience 28:448-453. 


\title{
Estimating aboveground plant biomass using a photo- graphic technique
}

\author{
JOSÉ M. PARUELO, WILLIAM K. LAUENROTH, AND PABLO A. ROSET
}

Authors are assistant professor, IFEVA-Departamento de Ecología, Facultad de Agronomía. Universidad de Buenos Aires. Av. San Martín 4453 (1417) Buenos Aires. Argentina, Professor, Department of Rangeland Ecosystems Science and NREL. Colorado State University. Fort Collins, Colo. 80523 USA, and graduate student IFEVA-Departamento de Ecología, Facultad de Agronomía. Universidad de Buenos Aires. Av. San Martín 4453 (1417) Buenos Aires. Argentina.

\section{Abstract}

We present a non-destructive, photographic method to estimate biomass in semiarid grasslands. Though the method needs to be calibrated, it allows for a dramatic increase in the number of samples compared with the clipping method. The method is based on a relationship between the percentage of "green pixels" in a digital image and green biomass. We identified "green pixels" as those satisfying the following condition: G/B > 1 and G/R $>1$, where $G, B$ and $R$ are the intensities of a particular pixel in the green, blue, and red bands respectively. The percentage of green pixels of the image and green grass biomass showed a correlation of $0.87(n=36, p<0.001)$ when data were pooled from 3 sample dates. The relationship was slightly curvilinear and a log transformation of green biomass yielded a better correlation $(\mathbf{r}=$ $0.91, \mathrm{n}=36, \mathrm{p}<0.001)$. The percentage of green pixels showed a lower correlation with total green biomass than with grass biomass $(r=0.59$ for the linear model and 0.73 for the log transformed model). The relationship between the percentage of green pixels and either green grass or total green biomass changed during the growing season. Both the slope and the $\mathrm{Y}$-intercept of the model differed significantly among dates. Correlation coefficients for different dates ranged between 0.76 and 0.95 .

Key Words: ANPP estimation, non-destructive methods, semiarid grassland

Aboveground net primary production (ANPP) is a key attribute of grassland ecosystems. Aboveground net primary production data are relevant for both theoretical studies and applied research. Many functional and structural ecosystem traits are tightly related to aboveground net primary production, i.e. secondary production (McNaughton et al. 1989), root biomass and soil organic carbon (Sala et al. 1997). Aboveground net primary production can be used as an integrative attribute of ecosystem function (McNaughton et al. 1989). Aboveground net primary production is an important variable in natural resource management because it determines forage availability for both wild and domestic herbivores. Oesterheld et al. (1992) found a strong connection between stocking density and ANPP for South American rangelands.

This research was funded by NSF (Cross-site LTER project, grant 94-16815), CONICET (Argentina), Fundaciфn Antorchas and University of Buenos Aires.

Manuscript accepted 28 Jun. 1999.

\section{Resumen}

En este trabajo presentamos un método fotográfico no destructivo para estimar biomasa en pastizales semiáridos. A pesar de que necesita ser calibrado, este método permite un aumento dramático en el número de muestras, en comparación con el mEtodo de cortes. Este método está basado en la relación entre el porcentaje de "pixeles verdes" y la biomasa verde en una imagen digital. Identificamos "pixeles verdes" como aquellos que satisfac $^{\circ}$ an la siguiente condición: $G / B>1$ and $G / R>1$, donde $G, B$ y $R$ son las intensidades de un pixel particular en las bandas del verde, azul y rojo, respectivamente. El porcentaje de pixeles verdes en la imagen y la biomasa verde de los pastos mostró una correlación de $0.87(n=36, p<0.001)$ al agrupar los datos de 3 fechas de medición. La relación era ligeramente curvilínea y una transformación log de la biomasa verde arrojó una mejor correlación $(r=0.91, n=36, p<0.001)$. El porcentaje de pixeles verdes mostró una menor correlación con la biomasa verde total que con la biomasa de pastos $(r=0.59$ para el modelo lineal $y$ 0.73 para el modelo transformado $\log$ ). La relación entre el porcentaje de pixeles verdes y la biomasa verde de pastos o la biomasa verde total cambió durante la estación de crecimiento. Tanto la pendiente como la ordenada al origen del modelo difirieron significativamente entre fechas. Los coeficientes de correlación para las diferentes fechas oscilaron entre 0.76 y 0.95 .

Despite its importance, ANPP estimates for grasslands are scarce. Only a few experimental sites carry out regular long-term measurements of aboveground net primary production (see for example, Fernández et al. 1991, Briggs and Knapp 1995, Lauenroth and Sala 1992 and the ORNL DAAC at http://wwwecot.ornl.gov/npp/npp-home.html for some examples). The reason behind the lack of extensive ANPP databases is quite simple: it is time consuming and therefore expensive to estimate.

Net primary production is the rate of carbon accumulation in plants in an ecosystem, and it is generally calculated annually. However, ANPP estimates are not based on this rate, but on the changes in biomass through time (Lauenroth et al. 1986). Biomass is estimated a number of different ways including harvesting (Sims et al. 1978, Sala et al. 1981), visual estimates (Waite 1994), capacitance meter (Fletcher and Robinson 1956, Winkworth et al. 1962, Murphy et al. 1995), and spectral data (Tucker 1977) to name the most common methods. Photo keys 
have been also used to estimate biomass, however the overall accuracy of the method is low (Catchpole and Wheeler 1992). Double sampling techniques have been widely used to estimate biomass (Ahmed et al. 1983, Catchpole and Wheeler 1992). This approach involves the development of a regression equation between biomass and a variable easy to measure. The variables more commonly used were ground cover, sward height, total blade length per tiller and point contacts (Pasto et al. 1957, t'Mannetje 1976, Williamson et al. 1987).

Estimates of aboveground net primary production derived from changes in biomass are subject to under and over estimation errors (Lauenroth et al. 1986, Sala et al. 1988), both related to the number of biomass samples (in time or space) used to calculate ANPP. To increase both the availability of aboveground net primary production data and their accuracy, we need to be able to work with large sample sizes. Additionally, many studies need non-destructive methods because of small plot sizes or restricted areas. In this paper we present a non-destructive, photographic method to estimate biomass in grasslands. Biomass estimates are important in itself but also provide the basis to estimate ANPP (Lauenroth et al. 1986). Even though the method needs to be calibrated, it allows for a dramatic increase in the number of samples per operator compared to the clipping method. The method is based on a relationship between the percentage of green pixels in a digital image and green biomass.

\section{Methods}

This research was conducted at the Central Plains Experimental Range (CPER) in northcentral Colorado, North America (40 49'N Lat, $104^{\circ} 46^{\prime}$ W Long). The CPER is administered by the USDA Agricultural Research Service (ARS) and is a National Science Foundation funded Long Term Ecological Research site. Mean annual precipitation is $321 \mathrm{~mm}$ (SD $=98 \mathrm{~mm}$ ). Average annual temperature is $8.6^{\circ} \mathrm{C}\left(\mathrm{SD}=0.6^{\circ} \mathrm{C}\right)$. The climate of the CPER is typical of mid-continental semiarid sites in the temperate zone except for the large influence of the Rocky Mountains $60 \mathrm{~km}$ to the west. Maxima in precipitation and temperature occur in June, July, and August and minima occur in December, January, and February.

The vegetation is typical of the northern portion of the shortgrass steppe (Lauenroth and Milchunas 1992). The dominant species is the perennial bunch- grass Bouteloua gracilis H.B.K. Lag. Important associated species include Buchlöe dactyloides (Nutt.) Engelm, Opuntia polyacantha Haw, Sphaeralcea coccinea (Pursh) Rydb, and Carex eleocharis Bailey. All nomenclature follows The Great Plains Flora Association (1986).

We took photographs on 3 dates during the growing season (21 May, 10 June, 26 June 1996) of $0.25 \mathrm{~m}^{2}$ circular plots using a $35 \mathrm{~mm}$ single lens reflex camera (PENTAX PZ10) with a $28-70 \mathrm{~mm}$ zoom lens. The camera was mounted on a tripod facing down $1.4 \mathrm{~m}$ above the ground with an angle lower than 10 degrees from the vertical. We used color slide film (200 ASA) (Kodachrome). Pictures were taken between 11:00 and 15:00 on clear days. The slides were digitized as TARGA files (TGA) at a resolution that yielded an average size for an individual pixel of approximately $0.25 \mathrm{~mm}^{2}$ (ground area) (Fig. 1).

Aboveground biomass was harvested from each plot after the picture was taken. Plants were clipped at the soil surface and biomass was sorted into live and dead and by the following categories: grasses, forbs, lichens, and cactus. After sorting, the material was oven-dried at $50^{\circ} \mathrm{C}$ and weighed.

The estimates of green biomass from the images were based on the separation of the image into the 3 colors: red, green and blue. These primary colors are additive because their combination produces white. An image consists of 3 layers or matrices. Each layer is assigned to 1 additive color. Each pixel of each band has a particular intensity. In an 8-bit image, the intensity will range from 0 to $255\left(2^{8}\right)$. A pixel with an intensity of 255 on each of the 3 bands will be white. For a black pixel the intensity in each of the 3 bands will be 0 .

We identified "green pixels" as those satisfying the following condition:

$$
G / B>1 \text { and } G / R>1
$$

where $\mathrm{G}, \mathrm{B}$ and $\mathrm{R}$ are the intensities of a particular pixel in the green, blue and red bands respectively. We calculated the number and proportion of green pixels for the whole image. G_PIX is a DOS-based C-program that processes a pixel by pixel list of the input file (*.TGA) (a free copy of the program (G_PIX.EXE) is available at http://www.ifeva.edu.ar/pictures).

We performed simple correlation and regression analyses to investigate the strength of the relationship between the percentage of green pixels of the image and green grass biomass and total green biomass. We cropped the portion of the picture corresponding to the $0.25 \mathrm{~m}^{2}$

\section{$18 \%$ of green pixels}

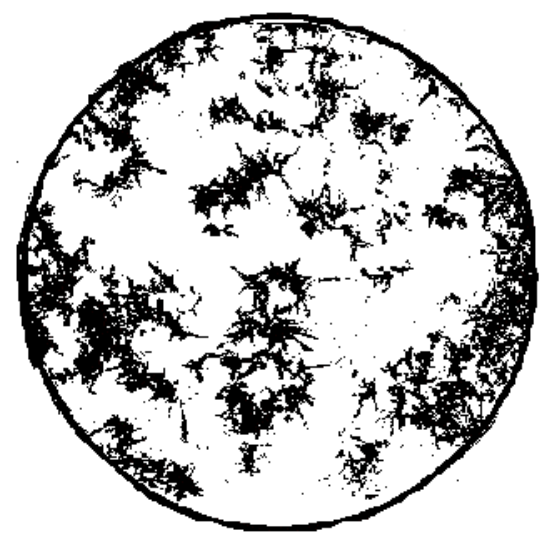

\section{$72 \%$ of green pixels}

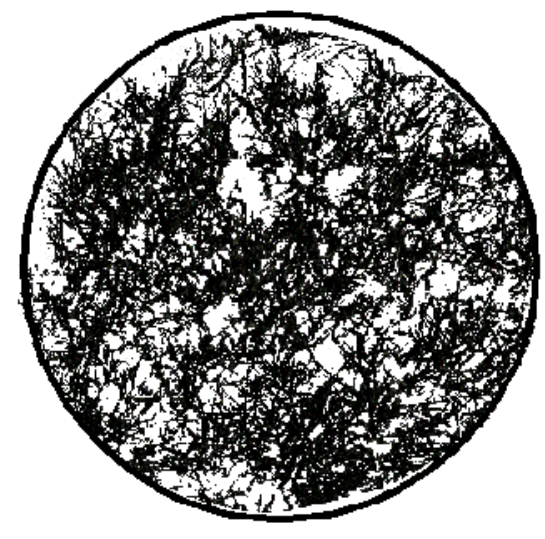

\section{$50 \mathrm{~cm}$}

Fig. 1. Pictures that show contrasting biomass and percentage of green pixels in the shortgrass steppe. The circle corresponds to the area sampled in the calibration experiment $\left(0.25 \mathrm{~m}^{2}\right)$. Green pixels appear as black and everything else as white.

quadrat using Adobe Photoshop 3.0 (Adobe Systems Incorporated 1994).

\section{Results and Discussion}

The percentage of green pixels and green grass biomass showed a correlation of $0.87(n=36, p<0.001)$ when data were pooled from all 3 sample dates (Fig. 2). The relationship was slightly curvilinear and a log transformation of green biomass yielded a better correlation $\mathrm{r}=0.91, \mathrm{n}=$ $36, \mathrm{p}<0.001$ ) (Fig. 2). The percentage of green pixels showed a lower correlation with total green biomass than with green grass biomass $r=0.59$ for the linear model 
and 0.73 for the log transformed model).

The relationship between the percentage of green pixels and either green grass or total green biomass changed during the growing season (Table 1 and Fig. 2). Both the slope and the Y-intercept of the regression model differed significantly among dates (Table 1). However, the differences of slopes and Y-intercepts were more marked for the relationship involving total green biomass than for green grass biomass. Changes in the relative contribution of different plant functional types (forbs, succulents, lichens, and grasses) and modifications of the canopy structure may account for the greater differences in the relationship between the percentage of green pixels and total green biomass compared to grass biomass.

Our results showed that digital images and an algorithm based on color theory can provide good estimates of plant biomass in semiarid grasslands. The method of counting green pixels is a variation of the point-quadrat method (Greig-Smith 1983). In this method plant cover, leaf area index, or biomass is calculated from the proportion of hits on green tissues over the total number of observations. By counting the number of green pixels we are dramatically increasing the total number of observations. The area sampled in this study $\left(0.25 \mathrm{~m}^{2}\right)$ included more than 70,000 pixels (it varies approx. $1 \%$ among pictures). As with the point-quadrat method, counting green pixels on a picture is a non-destructive method. That makes it especially useful for long-term studies of ANPP, plant cover or plant biomass.

This method also offers an interesting alternative for studying patch dynamics in arid and semiarid systems. Pictures allow one to track the dynamics of bare soil

Table 1. Correlation coefficients (r), slope, Y-intercepts, F-value and number of observations (n) for the linear models fit to the data of percentage of green pixels and green grass biomass $(\mathrm{g} / \mathrm{plot})(\mathrm{A})$ and total green biomass (g/plot) (B).

\begin{tabular}{lcccccc}
\hline \hline A) GREEN GRASS BIOMASS & & & & & \\
\hline Date & Y-intercept & Slope & $\mathrm{r}$ & $\mathrm{F}$ & $\mathrm{n}$ & \\
\hline 21 May & 3.91 & 0.21 & 0.90 & 17.5 & 6 & $* *$ \\
\hline 10 June & -4.04 & 0.38 & 0.95 & 17.9 & 2 & $* *$ \\
\hline 26 June & -21.3 & 0.52 & 0.88 & 28.6 & 1 & $* *$ \\
\hline **p p 0.01 & & & & & & \\
\hline \hline B) TOTAL GREEN BIOMASS & & & & & \\
\hline Date & Y-intercept & Slope & r & F & n & \\
\hline 21 May & -3.54 & 1.30 & 0.86 & 10.7 & 6 & $* *$ \\
\hline 10 June & 1.42 & 0.35 & 0.76 & 25.1 & 2 & $* *$ \\
\hline 26 June & -27.47 & 0.68 & 0.86 & 21.8 & 1 & $* *$ \\
\hline **p $<0.01$ & & & & & & \\
\hline
\end{tabular}

patches through time, recruitment of seedlings or the spread of clonal plants. The method proposed will be a useful tool

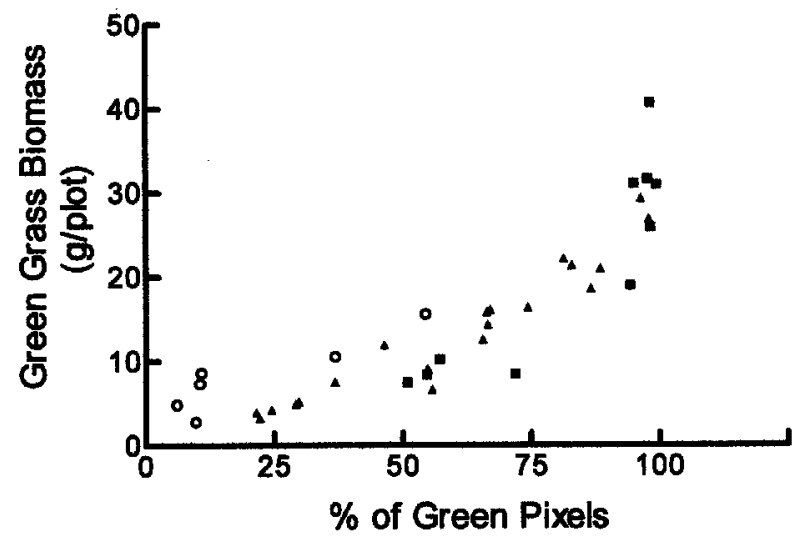

- June 26
- June 10
- May 21

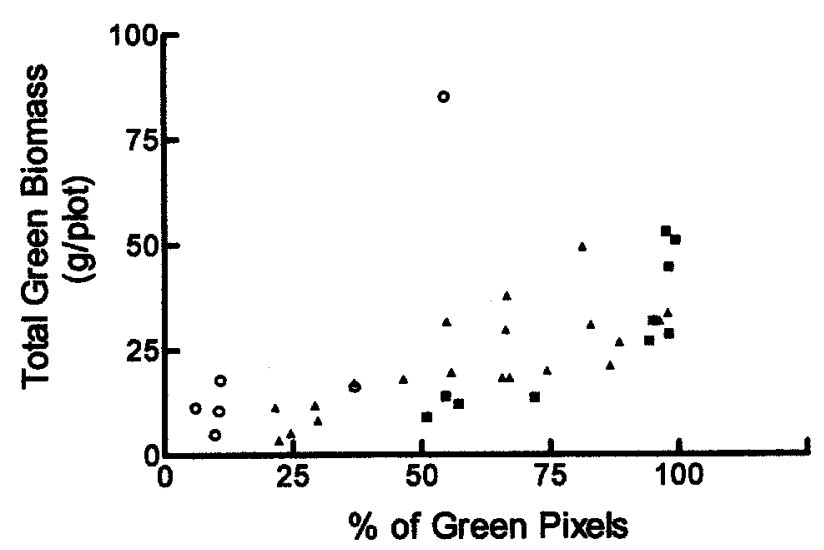

Fig. 2. Relationship between the percentage of green pixels and green grass biomass (GGB = $1.43+0.35 \ln (\% \mathrm{GP}), \mathrm{r}=0.91, \mathrm{p}<0.001)$ (the upper panel) and total green biomass (TGB $=1.94+0.017 \ln (\%$ GP $), r=0.73, p<0.001)$ (the lower panel). Open circles correspond to 21 May, triangles to 10 June and squares to June 26 sample dates.

for grassland and shrubland ecologists and managers. A picture represents a more objective alternative to assess plant cover or plant biomass than visual estimates. The use of digital cameras will speed up the process of assessing structural attributes of grassland and shrubland ecosystems. Pictures can be downloaded to the hard disk of a notebook computer from a digital camera directly in the field. G_PIX can calculate the percentage green pixels for a group of pictures and store the results in an ASCII file. Clearly multiple layers of leaves or complex canopies would reduce the accuracy of this approach. The shortgrass steppe presents a canopy structure near ideal to apply this method. For nonpostrate vegetation camera angles different from vertical may provide better estimates of green biomass.

The method requires, however, a proper calibration based on double sampling, harvesting biomass, and taking pictures. Our 
results suggest that our calibration was not stable throughout the growing season, mainly for total green biomass, and therefore requires a calibration at each sample date and vegetation type. The high correlation suggests that a small number of samples would be necessary to describe the relationship. Despite this requirement this method has a very high probability of improving the process of collecting aboveground biomass data in semiarid grasslands and shrublands.

\section{Literature Cited}

Adobe Systems Incorporated. 1994. Adobe Photoshop 3.0 User Guide. USA edition.

Ahmed, J., C.D. Bonham, and W.A. Laycock. 1983. Comparison of techniques used for adjusting biomass by double sampling. J. Range Manage. 36: 217-221

Briggs, J.M. and A.K. Knapp. 1995. Interannual variability in primary production in Tallgrass prairie: climate, soil moisture, topographic position, and fire as determinant of aboveground biomass. Amer. J. Bot. 82:1024-30.

Catchpole, W.R., and C.J. Wheeler. 1992. Estimating plant biomass: a review of techniques. Aust. J. Ecol. 17: 121-131

Fernández, R.J., O.E. Sala, and R.A. Golluscio. 1991. Woody and herbaceous aboveground production of a patagonian steppe. J. Range Manage. 44:434-7.
Fletcher, J.E., and M.E. Robinson. 1956. A capacitance meter for estimating forage weight. J. Range Manage.9:96-97

Great Plains Flora Association, McGregor, R.L., (coord.) \& Barkley, T.M. (ed). 1986. Flora of the Great Plains. Univ. Press of Kansas, Lawrence, Kans.

Greig-Smith, P. 1983. Quantitative plant Ecology. 3rd edition. Balckwell Scientific Publ.. Oxford.

Lauenroth, W.K., and D.G. Milchunas. 1992. Short-Grass Steppe. Ecosystems of the World: Nat. Grassl.. Elsevier, Amsterdam.

Lauenroth, W.K. and O.E. Sala. 1992. Long-Term forage production of North American shortgrass steppe. Ecol. Appl. 2:397-403

Lauenroth, W.K., H.W. Hunt, D.M. Swift, and J.S. Singh. 1986. Estimating aboveground net primary productivity in grasslands: a simulation approach. Ecol. Model. 33:297-314

McNaughton, S.J., M. Oesterheld, D.A. Frank, and K.J. Williams. 1989. Ecosystem-level patterns of primary productivity and herbivory in terrestrial habitats. Nature 341:142-144.

Murphy, W.M., J.P. Silman, and A.D. Mena Barreto. 1995. A comparison of quadrat, capacitance meter, HFRO sward stick, and rising plate for estimating herbage mass in a smooth-stalked, meadowgrass-dominant white clover sward. Grass Forage Sci. 50:452-455.

Oesterheld, M., O.E. Sala, and S.J. McNaughton. 1992. Effect of animal husbandry on herbivore-carrying capacity at a regional scale. Nature 356:234-6.
Pasto, J.K., J.R. Allison, and J.B. Washko. 1957. Ground cover and height of sward as a mean of estimating pasture production. Agron. J. 49: 407-409.

Sala, O.E., M.E. Biondini, and W.K. Lauenroth. 1988. Bias in estimates of primary production: An analytical solution. Ecol. Model. 44:43-55.

Sala, O.E., W.K. Lauenroth, and R.A. Golluscio. 1997. Plant functional types in temperate arid regions. Plant Functional Types. Cambridge Univ. Press, Cambridge.

Sala, O.E., V.A. Deregibus, T. Schlichter, and H. Alippe. 1981. Productivity dynamics of a native temperate grassland in Argentina. J. Range Manage. 34:48-51.

Sims, P., J.S. Singh, and W.K. Lauenroth. 1978. The structure and function of ten western North American grasslands. J. Ecol. 66:251-285.

t'Mannetje, L. 1976. Measurement of grassland vegetation and animal production. Commonwralth Bureau of pastures and Field Crops Bull 52. Hurley, Berkshire, England.

Tucker, C.J. 1977. Resolution of grass canopy biomass classes. Photogramm. Eng. Rem. S. 43:1059-1067.

Waite, R.B. 1994. The application of visual estimation procedures for monitoring pasture yield and consumption in exclosures and small plots. Trop. Grassl. 28:38-42.

Williamson, S.C., J.K. Detling, J.L. Dodd, and M.I. Dyer. 1987. Nondestructive estimation of shortgrass aerial biomass. J. Range Manage. 40: 254-256

Winkworth, R.E., R.A. Perry, and C.O. Rosetti. 1962. A comparison of methods of estimating plant cover in arid grassland community. J. Range Manage. 15:194-196 


\title{
Technical Note: A comparison of methods to determine plant successional stages
}

\author{
SUSAN R. WINSLOW AND BOK F. SOWELL
}

Authors are agronomist, USDA/NRCS, Plant Materials Center, Bridger, Mont. 59014; and assistant professor, Department of Animal and Range Sciences, Montana State University, Bozeman, Mont. 59717.

Abstract

Twenty-six, 0.04 ha macroplots were sampled on 9 range sites in southwestern Montana to compare successional scores and condition classifications of range condition analysis and United States Forest Service (USFS) Ecodata and Ecopac (Strata) analysis methods. Range condition scores $(0-100 \%)$ and range condition classes (poor, fair, good, excellent) were derived from the traditional Soil Conservation Service range condition analysis method, with the exception that only major decreaser and increaser graminoids and shrubs were individually clipped and bagged. Ecological status scores (1-100\%) and ecological condition classes (low, mid, high, very high) were determined with United States Forest Service Ecodata methods. Range condition score means were greater $(p<0.02)$ than ecological status score means $(48 \%$ vs $41 \%)$. Standing crop biomass affected differences ( $p<0.001)$ between range condition scores and ecological status scores. Lower producing sites had greater range condition scores than ecological status scores and higher producing sites had greater ecological status scores than range condition scores. Range condition classes and ecological condition classes were not independent $(\mathrm{p}<0.02$ ). Differences between the 2 methods were attributable to the use of species composition by weight for the range condition analysis and the use of percent canopy cover by Ecodata methods. Rangeland managers trying to determine successional status should realize that range condition analysis and Ecodata methods produce similar condition classes but different condition scores.

Key Words: Range condition, seral stages, plant communities, succession

Range condition analysis was developed to monitor forage productivity and to evaluate grazing effects on plant communities. Methods developed by the Soil Conservation Service (SCS) have been the standard to determine range condition and trends in the western United States for many years (Svejcar and Brown 1991). Changes in land management policy began in the 1960s after societal awareness identified a need for increased conservation and improvement of the environment leading to the adoption of ecological guidelines for ecosystem management by the U.S. Forest Service (USFS) (Robertson 1992).

The authors wish to express thanks to the USFS for their cooperation and assistance in the completion of this project. Thanks to the Flying D Ranch for access.

Manuscript Accepted 30 May 1999.

\section{Resumen}

Se muestrearon 26 macroparcelas (0.04 ha) en 9 sitios de pastizal del Sudoeste de Montana para comparar las calificaciones sucesionales y las clasificaciones de condición del análisis de condición del pastizal y de los métodos de análisis Ecodata y Ecopac ("Strata") del Servicio Forestal de los Estados Unidos (USFS).Las calificaciones de condición del pastizal (0-100\%) y las clases de condición del pastizal (pobre, regular, bueno y excelente) se derivaron del método tradicional de análisis de condición del pastizal del Servicio de Conservación de Suelos, con la excepción de que solo las principales especies de gramíneas y arbustos decresores e incresores se cortaron y empaquetaron individualmente. Las calificaciones del estado ecológico (1$100 \%$ ) y las clases de condición ecológica (bajo, medio, alto y muy alto) se determinaron con los métodos Ecodata del Servicio Forestal de los Estados Unidos. Las medias de las calificaciones de la condición del pastizal fueron mayores $(p<0.02)$ que las medias de la calificación del estado ecológico (48\% vs $41 \%)$. La biomasa de la cosecha en pie afecto las diferencias $(\mathbf{p}<0.001)$ entre las calificaciones de la condición del pastizal y las calificaciones del estado ecológico. En los sitos de baja producción las calificaciones de condición de pastizal fueron mayores que las del estado ecológico, en sitos con alta producción las calificaciones del estado ecológico fueron mayores que las de la condición del pastizal. Las clases de condición del pastizal y las de condición ecológica no fueron independientes $(\mathbf{p}<0.02)$. Las diferencias entre los 2 métodos se atribuyeron al uso de la composición de especies por peso para el caso de la condición de pastizal y al uso del porcentaje de cobertura de copa en los métodos Ecodata. Los manejadores el pastizal que intentan determinar el estado sucesional deberán reconocer que el análisis de condición del pastizal y los métodos Ecodata producen clases de condición similares pero diferentes calificaciones de condición.

Traditional methods employed by SCS to determine range condition scores and range condition classes were based on plant species composition by dry weight. These values were compared to "climax" for a given range site. Range condition scores $(0-100 \%)$ were determined according to the similarity of current vegetation compared to climax vegetation. Vegetation was further categorized into poor $(0-25 \%)$, fair (26-50\%), good $(51-75 \%)$ and excellent (76-100\%) condition classes to correspond with low, mid, high and very high seral stages. This method presents problems because climax vegetation is difficult to determine and secondary plant successional patterns may vary greatly on similar sites. Limitations of these methods have 
prompted federal agencies to develop other seral stage assessment methods which are more ecologically based.

There appears to be a trend by agencies towards more qualitative or observational methods to assess "range health" or "proper functioning condition". These methods do not yield any quantitative data for determining changes in plant communities over time. Therefore, some agencies have attempted to use quantitative methods to assess seral stages, which are based on different critera for determining potential natural plant communities.

In 1987, the Northern Region of the USFS began development of Ecodata and Ecopac as a standardized approach for environmental analysis and plant community classification (USDA 1987). The Northern Region proposed to inventory and classify vegetation based on Ecodata sampling methods and manage 3 million ha of public grazing allotments based on a determination of ecological status (RISC 1983).

The Strata program categorizes current vegetation and compares it to potential natural communities based on canopy cover. The degree of similarity between current vegetation and potential natural community is determined by Sorensen's quotient of similarity (Sorensen 1948). This quotient is determined by plant species occupancy in sampled communities compared to reference plant communities. An ecological status score is given from 1 to 100 and the seral stage is classified into 1 of 4 ecological condition classes (low, mid, high, very high) in $25 \%$ increments (USDA 1987).

The relationship of Ecodata sampling methods to standard range condition analysis methods has not been established and a lack of continuity exists in information gathered with different methods. A comparison of the Ecodata method to the standard range condition analysis would provide managers a basis for understanding Ecodata's relationship between ecolog ical condition classes and range condition classes. The purpose of this study was to compare successional scores and condition classes derived from range condition analysis and Ecodata sampling methods on a variety of range sites. The objectives were to: 1) compare range condition scores and ecological status scores; 2) compare range condition classes and ecological condition classes; and 3) to determine those environmental parameters that may influence the differences between the range condition and ecological status scores. To our knowledge, similar pub- lished comparisons between these methods do not exist.

\section{Methods}

\section{Study Area}

The study was conducted on the Flying D Ranch, $\left(45^{\circ} \mathrm{N}, 111^{\circ} \mathrm{W}\right), 16 \mathrm{~km}$ southwest of Bozeman, Mont., in Gallatin and Madison counties (USDA 1989). The 60,700 hectare ranch is characterized by intermontane valleys at 1,280-2,300 m elevations. The majority of the ranch receives $38-48 \mathrm{~cm}$ of annual precipitation an average annual temperature of $4.4^{\circ} \mathrm{C}$ and a 75 day frost-free period (USDA 1989).

Soils were classified as Argie, Pachie, Calcic or Lithic Cryoborolls (USDA 1989). Bridger, Earcree, Hanson, OrofinoPoin, and Poin-Sebud soil series with sandy, silty, and clay loam textures dominated the study area and were frequently modified by gravel, cobble, or stone fragments (USDA 1989, 1994). Potential natural communities varied with range site and average forage production values ranged from 300 to $1,200 \mathrm{~kg} / \mathrm{ha}^{-1}$ (USDA 1989). Dominant plant species across range sites included big sagebrush (Artemesia tridentata [Nutt.]), bluebunch wheatgrass (Pseudoroegneria spicata [Pursh] A. Love), Idaho fescue (Festuca idahoensis [Elmer]), lupine (Lupinus L), needle-and-thread (Stipa comata [Trin. and Rupr.]), prairie Junegrass (Koeleria macrantha [Ledeb.] J.A. Schultes), western needlegrass (Stipa occidentalis) Thurb. ex S. Wats.), and western wheatgrass (Pascopyrum smithii [Rydb.] A. Love) (Ross and Hunter 1976).

\section{Site Descriptions and Locations}

Twenty-six, $11.3 \mathrm{~m}$ radius (0.04 ha) permanent Ecodata macroplots were established on the ranch as part of a baseline range condition inventory in 1990. Sampling was concentrated in grassland and shrub steppe rangeland to evaluate a variety of range sites (Westech 1991). Ecodata macroplots were established in major range sites and location was based on vegetation composition, soils, and precipitation information. Site selection in riparian corridors was minimal due to significant modification of lowland vegetation by livestock grazing and apparent poor condition. Upland areas were sampled more intensively to determine the extent of fair to excellent condition range sites and a number of range sites were sampled at several locations. Range condi- tion and ecological status were compared on range sites/habitat types that had species composition data available for similarity analysis. Macroplots were established in a representative, homogenous range site/habitat type and permanently located with a $1.6-\mathrm{cm}$ diameter capped rebar pin. Exact site locations and landmark descriptions are reported in Westech (1991).

\section{Sampling}

Plots were sampled in August 1990 according to the Ecodata ocular method, using the Ecodata ocular method, as outlined in Chapter 4 of the Ecosystem Classification Handbook (USDA 1987). Environmental features of the macroplot were noted and potential natural community and habitat type were determined with classification systems developed by Hansen et al. (1988), Mueggler and Stewart (1980), and Pfister et al. (1977). Range site was determined using SCS soil survey maps (USDA 1989). Site characteristics described included: soil type, plot position on the landscape, parent material, aspect, elevation, percent slope, and ground cover characteristics. Vegetation structure and production for the macroplot were recorded. Identification of dominant species (height $\mathrm{x}$ canopy cover) by vertical layer and estimation of total percent vegetative cover by life-form were determined.

Annual standing crop biomass was determined by clipping vegetation. Plant species identified as major decreaser graminoids, major increaser graminoids, or shrubs were individually clipped and bagged (USDA 1981). Other perennial forb species, annual/biennial forbs, minor decreaser graminoids, minor increaser graminoids, or annual graminoids were grouped into 1 separate class. Actual production was determined from 3 randomly placed, $0.5 \times 1.0 \mathrm{~m}$ microplots within an Ecodata macroplot. Current year aboveground herbaceous biomass for each class of vegetation was clipped to ground level and bagged. Production samples were ovendried at $70^{\circ} \mathrm{C}$ until constant weight was achieved (48-96 hours). Biomass ( $\left.\mathrm{kg} \mathrm{ha}^{-1}\right)$ for each vegetation class, from each microplot, were used in determining mean macroplot production.

Ocular Plant Species Data Form 4 (USDA 1987) was used to record characteristics of the macroplot vegetation. Species life-form, percent canopy cover class, and mean height to the nearest foot were defined. Plants were identified by genus and species using Dorn (1984), Great Plains Flora Association (1986), 
Hitchcock et al. (1955-1969), and Hitchcock and Cronquist (1973). The USFS species list (USDA 1987) was used as standard nomenclature for entry into the plant composition database.

\section{Determination of Range Condition and Classification}

Range condition calculations were based on clipped forage weights of each vegetation class. Relative percent composition, for each vegetation class in each plot, was determined by dividing the dry weight of the class by total plot production. Existing relative percent compositions were then compared to the climax community species percent composition listed in the USDA SCS range site technical guides (1977). Actual amounts, not in excess of that shown in the guide, were totaled for all vegetation classes to arrive at the numerical range condition scores, a relative ecological rating of floristic similarity to climax community, for the plot (USDA 1981). The plot was then classified into 1 of 4 range condition classes determined by $25 \%$ increments of the range condition scores (USDA 1976).

\section{Determination of Ecological Status and Condition}

Data from each of the 26 macroplots was entered into the Ecodata general form and plant composition data bases (Data General System 1985). The data bases were linked to the Ecodata analysis package (Ecopac) through the Utility system and checked for errors (USDA 1987). The Plotid program was used to group the Ecodata macroplots and create text files for input into the plant community analysis program, Strata. A species synthesis table (species abundance by plot and strata) and constancy-average table (species canopy cover) was generated to select plants common to the 26 macroplots and the 159 plots sampled by Mueggler and Stewart (1980). Plant species composition of Mueggler and Stewart (1980) plots was based on forty, $0.2 \times 0.5 \mathrm{~m}$ microplots per $20 \times 20 \mathrm{~m}$ (0.04 ha) macroplot. The number of species common to both plots was limited to 88 to reduce noise in the similarity analysis (Gauch 1982). The Mueggler and Stewart (1980) plots were grouped into potential natural communities. The Ecopac subroutine, Strata, characterized differences, based solely on the estimated species percent canopy cover, between the existing 26 macroplots and the potential natural communities (habitat type strata) of Mueggler and Stewart
(1980). The species composition of each study macroplot was compared to all 5 habitat types (potential natural communities) by plot-to-strata similarity analysis. The potential natural communities were Pseudoroegneria spicata/Poa sandbergii (Psespi/Poasan), Artemisia tridentata/Festuca idahoensis (Arttri/Fesida), Festuca idahoensis/Elymus caninus/Geranium viscosissimum phase (Fesida/ElyCan/Gervis), Festuca idahoensis/Pascopyrum smithii (Fesida/Passmi), and Festuca idahoensis/Pseudoroegneria spi cata (Fesida/Psespi). The numerical macroplot ecological status score was calculated as degrees of floristic similarity to potential natural communities using Sorensen's (1948) coefficient $K=100$ $(2 \mathrm{c} / \mathrm{a}+\mathrm{b})$, where $\mathrm{c}$ is the sum of percent canopy cover of a single species in two opposing plots, a is the canopy cover of all species in a plot (ie macroplot), and b is the canopy cover of all species in the other plot (ie Mueggler and Stewart's potential natural community plot). The plot was then classified into 1 of 4 ecological condition classes as determined by $25 \%$ increments of the ecological status scores (USDA 1992).

\section{Statistical Procedures}

Differences between the mean range condition scores and ecological status scores were compared using a non-parametric, two-tailed Wilcoxon's signed rank test (Steel and Torrie 1980). This was considered to be a more conservative approach than either the paired t-test or analysis of variance since the two sampling methods were employed at the same location, on the same day. The Wilcoxon's signed rank test only assumes data can be ranked and there are very few ties when ranking values. No other assumptions of independent sampling or normally distributed differences are necessary. There was only one tied rank in the data, therefore this was considered a valid statistical test. Plot was considered the experimental unit for this and all subsequent analyses. A paired t-test (SAS 1988) was used to compare differences of range condition scores and ecological status scores within similar range sites grouped across precipitation zones.

Range condition classes were poor, fair, good, and excellent and ecological condition classes were low, moderate, high, and very high. The 4 condition classes, for both methods, represented successional score percentage breaks of 0-25, 26-50, 51-75, and 76-100. Analyses of range condition classes and ecological condition classes were based on 21 of the 26 plots. A $2 \times 2$ contingency table was used to meet the criteria of having a minimum expected cell count of 5 (McClave and Dietrich 1985). Five plots were excluded because they represented single occurrences in the columns of the contingency table which render the statistical inference invalid for those columns. Class scores were transformed into numerical form (1-4). To determine the degree of independence between range condition classes and ecological condition classes, ChiSquare analysis (MSUStat 1994) was conducted with the 2-way contingency table. Association groups were determined according to the probability of such associations occurring by chance.

The difference between range condition scores and ecological status scores for each of the 26 plots was determined. Regression analysis (SAS 1988) was used to determine the influences of aspect, elevation, precipitation, production, range site, and slope on differences between range condition scores and ecological status scores. Range sites were grouped irrespective of precipitation zone. All statistical comparisons were evaluated at $p<0.05$.

\section{Results}

Five hundred fifty-two vascular plant taxa were identified in the survey of the 9 range sites. Forage production values ranged from $139 \mathrm{~kg} \mathrm{ha}^{-1}$ on the very shallow $38-48 \mathrm{~cm}$ precipitation range site, to $4,708 \mathrm{~kg} \mathrm{ha}^{-1}$ on the silty $50+\mathrm{cm}$ precipitation range site (Westech 1991). Range condition scores varied from $15 \%$ on a silty $50+\mathrm{cm}$ precipitation range site to $78 \%$ on the silty $25-26 \mathrm{~cm}$ precipitation range site. Poor range condition classes occurred on $4 \%$ of the plots, fair condition on $54 \%$ of the plots, $35 \%$ of the plots were found to be in good condition, and $8 \%$ were in excellent condition. Ecological status scores varied from $13 \%$ on the Fesida/Passmi habitat type to $57 \%$ on the Psespi/Poasan/Sticom habitat type. Low ecological condition classes occurred on $12 \%$ of the plots, $62 \%$ of the plots were moderate, and $27 \%$ were classified as high ecological condition.

There was a $15 \%$ difference $(\mathrm{p}<0.02)$ between the range condition scores mean $(48 \%)$ and the mean ecological status scores $(41.3 \%)$. There were no differences $(p>0.05)$ between range condition scores and ecological status scores within range sites (Table 1) with 1 exception. This occurred on the very shallow sites $(n=2)$, 
Table 1. Comparison of mean range condition scores (RCS) and ecological status scores (ESS) for 24 macroplots in the same range sites (grouped across precipitation zones) in southwest Montana.

\begin{tabular}{lrccc}
\hline \hline Range Site & $\mathrm{n}$ & $\mathrm{RCS}$ & $\mathrm{ESS}$ & P-Value \\
\hline & & $(\%)$ & $(\%)$ & \\
Silty & 13 & 49 & 37 & 0.54 \\
Shallow & 7 & 47 & 44 & 0.78 \\
Very Shallow & 2 & 57 & 27 & 0.02 \\
Overflow & 2 & 24 & 27 & 0.82 \\
\hline
\end{tabular}

where productivity was lower than other range sites.

Categorizing vegetation into mid or fair ecological condition and high or good range condition classes resulted in 16 of 21 plots being placed in the same seral categories. Chi-Square analyses revealed that range condition and ecological condition methods used to categorize condition classes or seral stages were not independent $(\mathrm{p}<0.02)$.

Regression analysis indicated that aspect, elevation, habitat type, and precipitation did not affect differences between range condition scores and ecological status scores (Table 2). Production (Fig. 1) and range site $(\mathrm{p}<0.001$ and $\mathrm{p}<0.04)$ were the only variables that affected the differences between range condition scores and ecological status scores. The equations of linear relationship between ecological status scores minus range condition scores and all other variables are provided in Table 2. Lower producing sites had greater range condition scores than ecological status scores and higher producing sites had greater ecological status scores than range condition scores (Fig. 1).

\section{Discussion}

Differences between range condition scores and ecological status scores were probably related to different assessment methods. Relative percent species compo-
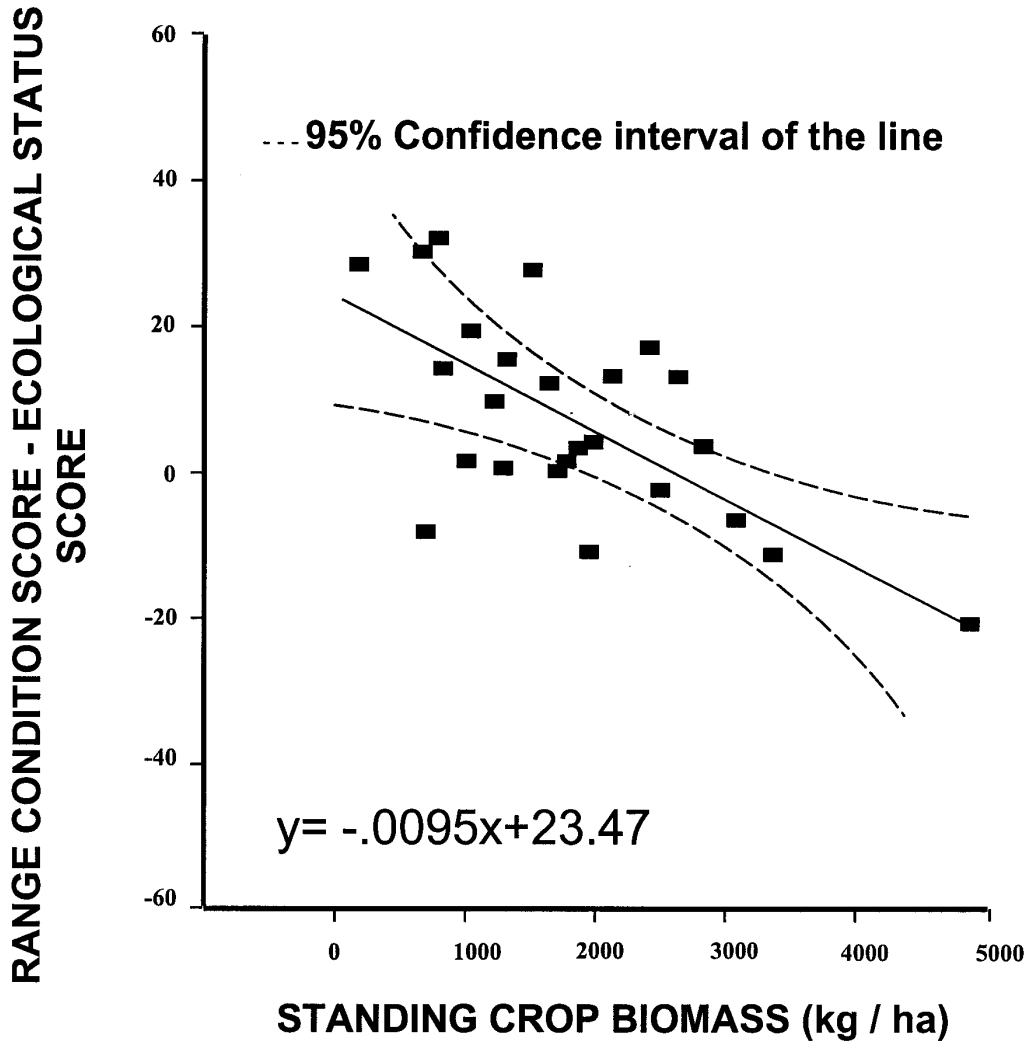

Fig. 1. Standing crop biomass effects on range condition score minus ecological status score on 26 macroplots in southwest Montana.

sition by weight used in the range condition analysis method favors plants that produce more biomass, while the Ecodata system emphasizes canopy cover. Payne (1974) found that the average correlation of cover and weight was 0.62 for all grass species and provided evidence that correlations between weight and cover could vary from $R=0.98$ to $R=0.14$ depending on the individual plant species. Therefore, differences between ecological status scores and range condition scores could be due to variable correlations between plant weight and canopy cover.

Percent canopy cover estimates used with the Ecodata method are placed in cover class ranges, assigned a standard

Table 2. Simple linear equations and statistics for the effect of seven variables on the differences between range condition score and ecological status score in southwestern Montana.

\begin{tabular}{llll}
\hline \hline Source & \multicolumn{1}{c}{ Equation } & $\mathrm{R}$ & P-Value \\
\hline Aspect & $\mathrm{y}=-0.03 \mathrm{x}+13.02$ & 0.24 & 0.21 \\
Elevation & $\mathrm{y}=-0.003 \mathrm{x}+12.87$ & 0.1 & 0.83 \\
Range Sites & $\mathrm{y}=5.01 \mathrm{x}+-2.28$ & 0.4 & 0.04 \\
Habitat Type & $\mathrm{y}=-0.24 \mathrm{x}+8.09$ & 0.1 & 0.78 \\
Precipitation & $\mathrm{y}=-0.61 \mathrm{x}+33.49$ & 0.17 & 0.38 \\
Standing Crop Biomass & $\mathrm{y}=-0.0095 \mathrm{x}+23.47$ & 0.32 & 0.001 \\
Slope & $\mathrm{y}=0.31 \mathrm{x}+0.39$ & 0.67 & 0.11 \\
\hline
\end{tabular}

class midpoint, and assigned a class code. For example, in the canopy cover range of $1-<5 \%$, the midpoint is $3.0 \%$, and in the range of $35-45 \%$, the midpoint is $40.0 \%$ (the median). The assigned midpoint may be biased by extremely low or high estimates (Daubenmire 1968). The experience of the investigator may affect the estimate. Plots with very low foliage cover are likely to be underestimated, and plots with greater foliar cover are likely to be overestimated (Meuller-Dombois and Ellenberg 1974). This may partially explain why ecological status scores are lower on sites with lower production and higher on sites with greater production.

Differences in the scores were probably not attributed to different concepts of climax or potential natural communities classification. Range site and habitat type have been found to classify the land unit and potential vegetation in essentially the same fashion (Hironaka 1989). Both the range site and habitat type concepts are based on soil characteristics unique to a site and on the differences in expected climax plant composition and production on the same site.

Mueggler and Stewart (1980) sampled 0.04 ha macroplots near-pristine areas and 
areas subject to mild grazing disturbance to determine climax plant communities. Our study used the same size macroplots as Mueggler and Stewart (1980), therefore it is unlikely that differences between the 2 methods were the result of plot size influences.

Range managers often rely on condition classes for management purposes. There were no differences in range condition classes and ecological condition classes. It appears that these classifications could be used interchangeably.

\section{Conclusions}

In this study, the mean of the ecological status scores, as determined by USFS Ecodata, was lower $(p<0.02)$ than the mean of the range condition scores, as determined by the SCS range condition analysis method. When conducting range inventories, Ecodata methods may indicate a decline in vegetation resources when the results are compared to range condition analysis methods. Differences between ecological status scores and range condition scores were probably due to variable correlations between plant weight and cover. Resulting condition classification from both Ecodata and range condition analysis methods were the same. These findings indicate that categorization of vegetative seral stages are comparable and that both methods are based on similar comparisons to climax or potential natural plant communities.

\section{Literature Cited}

Data General System. 1985. AOS/VS INFOS II system user's guide. Data General Corp., Westburo, Mass.

Daubenmire, R. 1968. Plant communities, a textbook of plant synecology. Harper \& Row, New York, N.Y.

Dorn, R.D. 1984. Vascular plants of Montana. Mountain West Publishing, Cheyenne, Wyo.

Gauch, H.G. Jr. 1982. Multivariate analysis in community ecology. Cambridge Univ. Press, Cambridge, Mass.

Great Plains Flora Association. 1986. Flora of the Great Plains. University Press of Kansas, Lawrence, Kan.

Hansen, P.L., S.W. Chadde, and R.D. Pfister. 1988. Dominance types of Montana. Montana Riparian Association. Misc. Publ. Number 49, School of Forestry, Univ. of Montana, Missoula, Mont.

Hironaka, M. 1989. Relationship of habitat type and range site, p. 300-301. In: D.E. Ferguson, P. Morgan, and F.S. Johnston (compilers), Proc. Land Classifications
Based on Vegetation: Applications for Resource Management. Moscow, Idaho. USDA U.S. Forest Serv. Gen. Tech. Rep. INT-257. Ogden, Ut.

Hitchcock, C.L. and A. Cronquist. 1973. Flora of the Pacific Northwest. Univ. of Washington Press, Seattle, Wash.

Hitchcock, C.L., A. Cronquist, M. Ownbey, J.W. Thompson. 1955-1969. Vascular plants of the Pacific Northwest. Vols. 1-5, Univ. of Washington Press, Seattle, Wash.

McClave, J.T. and F.H. Dietrich. 1985. Statistics. Dellen Publishing Company c/o Macmillan Publishing Company Front and Brown Streets, Riverside, N. J. 08075.

MSUStat. 1994. MSUStat Statistical Analysis Package, Users Guide. Res. \& Dev. Inst., Inc. Bozeman, Mont.

Mueggler, W.F., and W.L. Stewart. 1980. Grassland and shrubland habitat types of Western Montana. USDA U.S. Forest Serv. Gen. Tech. Rep. INT-66. Ogden, Utah.

Mueller-Dombois, D., and H. Ellenberg. 1974. Aims and methods of vegetation ecology. John Wiley \& Sons, New York, N.Y.

Payne, G.F. 1974. Cover-weight relationships. J. Range Manage. 27:403-404.

Pfister, R.D., B.L. Kovalchik, S.F. Arno, and R.C. Presby. 1977. Forest habitat types of Montana. USDA U.S. Forest Ser. Gen. Tech. Rep. INT-34. Ogden, Ut.

RISC. 1983. Guidelines and Terminology of Range Inventories and Monitoring. Rep. of Range Inventory Standardization Com. Soc. for Range Manage., Denver, Colo. pp. 13.

Robertson, F.D. 1992. Ecosystem management of the national forests and grasslands. USDA USFS, Wash., D.C. 1330-1 policy letter, 4 June 1992.

Ross, R.L., and H.E. Hunter. 1976. Climax vegetation of Montana. USDA Soil Conservation Service, Bozeman, Mont. 64 p.

SAS Institute Inc. 1988. SAS/Stat users guide, version 6. SAS Institute Inc., Cary, N.C.

Sorensen, T. 1948. A method of establishing groups of equal amplitude in plant sociology based on similarity of species content. Det Kong. Danske Vidensk.Selsk. Biol. Skr. 5(4):1-34. Copenhagen.

Steel, R.G.D. and J.H. Torrie. 1980. Principles and procedures of statistics, a biometrical approach. McGraw-Hill Book Company, New York, N.Y.

Svejcar, T., and J.R. Brown. 1991. Failures in the assumptions of the condition and trend concept for management of natural ecosystems. Rangelands 13:165-167.

USDA Natural Resources and Conservation Service. 1994. Soil survey of Gallatin County area, Mont. Bozeman, Mont.

USDA Soil Conservation Service. 1976. National range handbook. NRH-1. Wash., D.C.

USDA Soil Conservation Service. 1977. Grazing guide for potential climax forest sites and condition classes, Montana foothills and mountains area. Bozeman, Mont.

USDA Soil Conservation Service. 1981. Technical guide to range sites and condition classes, Montana foothills and mountains.
National soils handbook, amend. MT-1. p. 407(1)-407(6). Bozeman, Mont.

USDA Soil Conservation Service. 1989. Soil survey of Madison County area, Mont. Bozeman, Mont. 384p. plus maps.

USDA U.S. Forest Service. 1987. Ecosystem classification handbook. Chapter fourEcodata sampling method. FSH 12/87 R-1. Missoula, Mont.

USDA U.S. Forest Service. 1992. Draft ecosystem classification and analysis guide. Chapter five-Plot level analysis programs. FSH 7/92 R-1. Missoula, Mont.

Westech. 1991. Baseline range condition evaluation and inventory of sensitive plant species for the Flying D Ranch, Madison and Gallatin Counties, Montana, 1990. Western Technology and Engineering, Inc. Helena, Mont. 


\title{
Carbon exchange rates in grazed and ungrazed pastures of Wyoming
}

\author{
DANIEL R. LECAIN, JACK A. MORGAN, GERALD E. SCHUMAN, JEAN D. REEDER, AND RICHARD H. HART
}

Authors are plant physiologists, USDA-ARS, Crops Research Laboratory, Fort Collins, Colo; soil scientist, USDA-ARS High Plains Grasslands Research Station, Cheyenne Wyo.; soil scientist, USDA-ARS Crops Research Laboratory, Fort Collins, Colo; and rangeland scientist, USDA-ARS High Plains Grasslands Research Station, Cheyenne Wyo.

\begin{abstract}
The influence of cattle grazing on carbon cycling in the mixed grass prairie was investigated by measuring the $\mathrm{CO}_{2}$ exchange rate in pastures with a 13 year history of heavy or light grazing and an ungrazed exclosure at the High Plains Grasslands Research Station near Cheyenne, Wyo. In 1995, 1996 and 1997 a closed system chamber, which covered $1 \mathrm{~m}^{2}$ of ground, was used every 3 weeks from April to October to measure midday $\mathrm{CO}_{2}$ exchange rate. Green vegetation index (similar to leaf area index), soil respiration rate, species composition, soil water content, soil temperature, and air temperature were also measured to relate to $\mathrm{CO}_{2}$ exchange rates of the 3 grazing treatments. Treatment differences varied among years, but overall early season (mid April to mid June) $\mathrm{CO}_{2}$ exchange rates in the grazed pastures were higher (up to $2.5 \mathrm{X}$ ) than in the exclosure. Higher early season $\mathrm{CO}_{2}$ exchange rates were associated with earlier spring green-up in grazed pastures, measured as higher green vegetation index. As the growing season progressed, green vegetation index increased in all pastures, but more so in the ungrazed exclosure, resulting in occasionally higher (up to $2 \mathrm{X}$ ) $\mathrm{CO}_{2}$ exchange rate compared with grazed pastures late in the season. Seasonal treatment differences were not associated with soil temperature, soil respiration rate, or air temperature, nor was there a substantial change in species composition due to grazing. We hypothesize that early spring green-up and higher early season $\mathrm{CO}_{2}$ exchange rate in grazed pastures may be due to better light penetration and a warmer microclimate near the soil surface because of less litter and standing dead compared to the ungrazed pastures. When all the measurements were averaged over the entire season, there was no difference in $\mathrm{CO}_{2}$ exchange rate between heavily grazed, lightly grazed and ungrazed pastures in this ecosystem.
\end{abstract}

Key Words: Grazing, productivity, photosynthesis, soil respiration, species composition.

Domestic livestock grazing on rangelands has received much attention recently, as there is often disagreement on the impacts of grazing on ecosystem sustainability. The challenge is manag-

The authors thank Barry Weaver and Dean Ackerman for chamber design and construction, and for assistance with the $\mathrm{CO} 2$ exchange rate measurements, and Pamela Freeman and Stanley Clapp for doing the point quadrat measurements and collecting the climate data. We also thank D.G. Milchunas and H.W. Hunt for excellent and timely reviews.

Manuscript accepted 17 Jul. 1999.

\section{Resumen}

En la Estación Experimental High Plains, cercana a Chayenne, Wyo., se investigo la influencia del apacentamiento de ganado en el reciclaje de carbón en pastizales mixtos. La determinación se efectuó mediante la medición de la tasa intercambio de $\mathrm{CO}_{2}$ en potreros con un historial de 13 años de apacentamiento fuerte o ligero y en potreros excluidos al apacentamiento. Durante el período de Abril a Octubre de 1995, 1996 y 1997 se utilizó un sistema de cámara cerrada (el cual cubría un $1 \mathrm{~m}^{2}$ ) a intervalos de 3 semanas para medir la tasa de intercambio de $\mathrm{CO}_{2}$ al mediodía. También se midieron el índice de vegetación verde (similar al índice de área foliar), la tasa de respiración del suelo, la composición botánica, el contenido de agua del suelo y la temperatura del suelo y aire para relacionarlos con las tasas de intercambio de $\mathrm{CO}_{2}$ de los 3 tratamientos de apacentamiento. Las diferencias entre tratamientos difirieron entre años, pero en general a inicios de la estación (Abril a Junio) las tasas de intercambio de $\mathrm{CO}_{2}$ de los potreros apacentados fueron mayores (hasta 2.5 veces) que las tasas de los potreros excluidos. Las altas tasas de intercambio de $\mathrm{CO}_{2}$ de inicios de estación se asociaron con altos índices de vegetación verde. Conforme la estación de crecimiento avanzó, el índice de vegetación verde aumento en todos los potreros, pero este incremento fue mayor en los potreros sin apacentamiento resultando en tasas de intercambio de $\mathrm{CO}_{2}$ ocasionalmente altas (hasta 2 veces) en comparación con los potreros apacentados a fines de la estación. Las diferencias estacionales de los tratamientos no se asociaron con la temperatura el suelo, la tasa de respiración del suelo o la temperatura del aire, ni tampoco hubo un cambio substancial en la composición de especies vegetales debido al apacentamiento. Nosotros hipotetizamos que el rebrote temprano de primavera y las tasas altas de intercambio de $\mathrm{CO}_{2}$ a inicios de estación de los potreros apacentados puede deberse a una mejor penetración de la luz y a un microclíma más cálido cerca de la superficie del suelo, esto porque hay menos mantillo y vegetación muerta en pie en comparación con los potreros sin apacentar. Cuando todas las mediciones se promediaron en toda la estación completa no hubo diferencias en la tasa de intercambio de $\mathrm{CO}_{2}$ entre los potreros con apacentamiento fuerte, ligero $\mathrm{y}$ sin apacentamiento.

ing these important lands to provide food and products for society, while protecting this natural resource base. As human population increases, so do the demands on rangelands, making it even more important to understand the effects of management strategies on rangelands. 
Many of the world's rangelands have historically been grazed by large mammals, and there is convincing evidence that grasses co-evolved with grazers (Stebbins 1981). As many as 20 million bison existed on the Great Plains of North America before European settlement (Shaw 1995). Therefore, grazing by large mammals is the natural condition of the Great Plains (Milchunas et al. 1988).

The effect of grazing on primary productivity and the carbon cycle are important factors in the long-term sustainability of these ecosystems. However, the information of how animal grazing impacts primary productivity and carbon cycling is limited and inconsistent. For instance, depending on the particular study and rangeland investigated, one can find examples of negative, neutral or positive effects of grazing on above-ground net primary productivity (Milchunas and Lauenroth 1993, Sims and Singh 1978b). McNaughton (1979) maintains that an optimal level of grazing will maximize annual net primary productivity in most rangeland ecosystems, so presumably most of the negative effects of grazing may be examples of over-grazing for a particular ecosystem. Bremer et al. (1998) reported that grazing reduced annual soil respiration by up to $18 \%$ in the tallgrass prairie, indicating that grazing may have a large effect on the carbon cycle of this ecosystem.

Over time, soils will integrate long-term above and below-ground ecosystem processes (Manley et al. 1995, Berg et al 1997). Therefore, soil carbon can be a good relative indicator of the effect of grazing on many aspects of the carbon cycle. However, as with plant productivity, there are reports that grazing increases (Smoliak et al. 1972, Ruess and McNaughton 1987, Schuman et al. 1999), decreases (Bauer et al. 1987, Dormaar and Willms 1998) or does not affect soil carbon (Berg et al. 1997, Milchunas and Lauenroth 1993). Changes in species composition and accompanying changes in rooting patterns resulting from grazing can sometimes explain changes in soil carbon (Smoliak et al. 1972).

An important topic that has not been addressed in the evaluation of how grazing impacts rangeland primary productivity is the photosynthetic response of plant communities to grazing. Many studies have investigated the influence of grazing or simulated grazing on the photosynthesis of individual plants or leaves (Wallace 1990, Painter and Detling 1981). Clipping increases tillering in some grass species and typically stimulates photosynthesis in remaining leaves (Painter and Detling 1981, Detling et al. 1979). However, it is difficult to extrapolate results from single plant or leaf studies to the community level, where species interactions and competition may have a greater impact. Morgan and Brown (1983) reported a positive relation between leaf area index and canopy photosynthesis in mowed Bermudagrass swards. However, there have been few reports of photosynthesis measured on an actively grazed native plant community (McNaughton et al. 1996).

In the mixed grass prairie of southeastern Wyoming, Manley et al. (1995) and Schuman et al. (1999) measured soil carbon of pastures grazed for 12 years vs. ungrazed exclosures. They found greater soil carbon in the upper $30 \mathrm{~cm}$ of soil of grazed pastures compared with ungrazed pastures. Although minor changes in species composition resulted from grazing, this did not help explain the differences in soil carbon.

As a first step towards a more systems oriented approach to understanding the effects of cattle grazing on the carbon cycle in the mixed grass prairie, we investigated how grazing treatments of the same pastures examined by Manley et al. (1995) affected plant community photosynthesis. We hypothesized that the result of grazing on plant community $\mathrm{CO}_{2}$ exchange rate would depend on how grazing affected the photosynthetic surface area of the canopy. We expected that treatment differences in $\mathrm{CO}_{2}$ exchange rate could be explained by corresponding differences in green vegetative surface area of the pasture.

\section{Materials and Methods}

The study site is near Cheyenne Wyo., USA, at the USDA-ARS High Plains Grasslands Research Station (lat. $41^{\circ} 11^{\prime}$ $\mathrm{N}$, long. $104^{\circ} 54^{\prime} \mathrm{W}$ ). The region is a northern mixed-grass prairie with elevations averaging $1,930 \mathrm{~m}$, mean annual precipitation averaging $38.4 \mathrm{~cm}$ and an average of 127 frost free days. Mean air temperatures are $17.5^{\circ} \mathrm{C}$ in summer and $-2.5^{\circ} \mathrm{C}$ in winter, with maximum July temperatures averaging $27^{\circ} \mathrm{C}$. The major cool-season grasses are western wheatgrass (Pascopyrum smithii (Rydb.) A. Love) and needle-and-thread grass (Stipa comata Trin and Rupr.), and the major warm season grass is blue grama (Bouteoloua gracilis (H.B.K.) Lag. Ex
Steud.). The soils are a mixed, mesic, Aridic Argiustolls with the soil series being an Ascalon sandy loam (Schuman et al. 1999).

The study was conducted on pastures grazed since 1982 at a continuous seasonlong (early June to mid-October) light stocking rate (21.6 steer-days $\left.\mathrm{ha}^{-1}\right)$, continuous season-long heavy stocking rate (62.7 steer-days ha $^{-1}$ ) and an ungrazed, 0.5 ha exclosure. The continuous heavy and continuous light stocking rate amounted to about $50 \%$ and $10 \%$ utilization of the annual production. The heavily and lightly grazed pastures share a fence and the exclosure is in the continuous light pasture. Before the initiation of these grazing treatments, the site had not been grazed by domestic livestock for 40 years (for more detail see Hart et al. 1988). The high labor requirements to perform these measurements permitted only 1 pasture of each grazing treatment being sampled to evaluate $\mathrm{CO}_{2}$ exchange rates. Initial soil sampling at the start of grazing trials showed that these pastures had the same soil type, thereby reducing experimental variability. The plant communities within each pasture were quite homogenous.

Metal, angle-iron frames that enclose 1 $\mathrm{m}^{2}$ of ground were driven into the soil along a transect established in 1982. The frames were level with the soil surface and had no apparent effect on cattle activity. Five frames per pasture (pseudo-replications), spaced $5 \mathrm{~m}$ apart, were installed along the transect for a total of 15. Canopy $\mathrm{CO}_{2}$ exchange rate was measured with a 40 (height) x $100 \times 100 \mathrm{~cm}$ 'Lexan' (Regal Plastics, Littleton, Colo. ${ }^{1}$ ) chamber, which had a closed-cell foam gasket on the base, which formed a seal with the metal frames. Air in the chamber was circulated by small fans, and a sample was pumped to a portable infrared gas analyzer (Analytical Development Co. model LCA-2, Hoddesdon, UK). The $\mathrm{CO}_{2}$ exchange rate is then estimated from the rate of $\mathrm{CO}_{2}$ depletion within the chamber. Measurements were performed rapidly (about 2 minutes) to minimize changes to the microclimate caused by the chamber (Angell and Svejcar 1999). $\mathrm{CO}_{2}$ exchange rate measurements were performed from about 1000 to 1300 hours (mountain standard time) approximately every 3 weeks during the growing seasons of 1995, 1996 and 1997. Diurnal measurements made during 1995 showed that maximum daily $\mathrm{CO}_{2}$ exchange rate

\footnotetext{
${ }^{1}$ Mention of a trademark or manufacturer by the USDA does not imply its approval to the exclusion of other products or manufacturers that may also be suitable.
} 
occurred at this time of day (also see Detling et al. 1978). The sequence of measurement among pastures was varied each date to reduce differences related to time of day. In 1995, we measured CO2 exchange rate on only 6 dates due to inclement weather during the spring (measurement requires cloud free conditions).

On each measurement date the point frame method was used to determine the relative photosynthetic surface area and species composition within each sample frame (Warren-Wilson 1963). Though the point frame method has limitations when used to determine leaf area index and for detecting less abundant species (Hazlett 1992, D. G. Milchunas pers. comm.) we considered it the best method of nondestructively determining photosynthetic surface area and species composition on plots which were repeatedly sampled. Green leaves, stems, and sheaths were recorded by the point frame since all 3 are significant contributors to photosynthesis (Caldwell et al. 1981). Total number of green tissue "hits" as 100 points were passed through the canopy of each $1 \mathrm{~m}^{2}$ plot (500 points per pasture) were recorded to get a "green vegetation index". The hits were identified by species for determination of community composition. Soil water content was estimated from 0-30 $\mathrm{cm}$ soil cores and converted to a volumetric basis by multiplying by the soil bulk density (Schuman et al. 1999). Air temperature and light intensity (Analytical Development Co. model PLC(N), Hoddesdon, UK) were also determined at the time of each $\mathrm{CO}_{2}$ exchange rate measurement. Seasonal precipitation and air temperature were obtained from a weather station near the site.

Soil respiration rate and soil temperature $(2.5 \mathrm{~cm}$ depth) were measured (PP Systems model SRC, Hertfordshire, UK.) on 5 small plots $\left(82 \mathrm{~cm}^{2}\right)$ next to each of the $1 \mathrm{~m}^{2}$ plots at the same time as the $\mathrm{CO}_{2}$ exchange rate measurements. Plastic rings were inserted about $2.5 \mathrm{~cm}$ into the ground and all above-ground vegetation was clipped from within the ring. These small plots rested for 2 weeks before soil respiration rate was measured to avoid $\mathrm{CO}_{2}$ fluctuations associated with soil disturbance. All above-ground vegetation was clipped prior to each measurement. These rings were moved twice during each season. In 1995 the soil respiration measuring equipment was not available until the later part of the season. Therefore, soil respiration rate was only measured on the last 2 sampling dates. The $\mathrm{CO}_{2}$ exchange rate, calculated on a ground surface area basis, was corrected for soil respiration by adding the soil respiration rate (when available) to the chamber $\mathrm{CO}_{2}$ exchange rate. Therefore, $\mathrm{CO}_{2}$ exchange rate comprises plant canopy photosynthesis and respiration only.

Statistical analysis such as analysis of variance are not appropriate for this experiment since we only have 1 true experimental unit per treatment. Data from the five, $1 \mathrm{~m}^{2}$ plots in each pasture are presented here as means + standard errors.

\section{Results}

Spring (May and June) of 1995 had greater than average precipitation, and May temperatures were cooler than long term averages (Fig. 1). Precipitation and temperature were more similar to longterm averages in 1996, while precipitation was higher than normal during the late summer of 1997 . Soil water content varied greatly depending upon the season, but the ungrazed pasture tended to have higher soil water content than either of the grazed pastures (Fig. 2). This was believed to be the result of the greater accumulation of litter and standing dead in the exclosure (Schuman et al. 1999), which acts as a mulch, particularly in the spring time after water has been stored during the winter (Bremer et al. 1998). Although it is not apparent in Figure 1, due to greater than normal early June and late July precipitation, in 1997 a significant drought occurred from mid June to late July (see Fig. 2)

On the first measurement date in 1995 (16 May), $\mathrm{CO}_{2}$ exchange rate was higher in both of the grazed pastures compared to the exclosure (Fig. 3A). Poor weather prevented sampling again for almost 4 weeks. On the next sampling date (13 June) the grazed plots again had higher $\mathrm{CO}_{2}$ exchange rates than the exclosure, although treatment differences were very small. The same trend suggests that there was a period of several weeks when the $\mathrm{CO}_{2}$ exchange rate was higher in the grazed vs. exclosed pastures. In contrast, $\mathrm{CO}_{2}$ exchange rate was typically lower in the grazed pastures in autumn. Seasonal trends in $\mathrm{CO}_{2}$ exchange rate among the grazing strategies were similar to trends in green vegetation index (Fig. 3B). Green vegetation index was higher in the grazed pastures on the first 2 measurement dates and was lower in the grazed pastures later in the season (green vegetation index was not measured on 14 September 1995). On the 2 dates that we measured soil respiration rate, the exclosure had the lowest res-

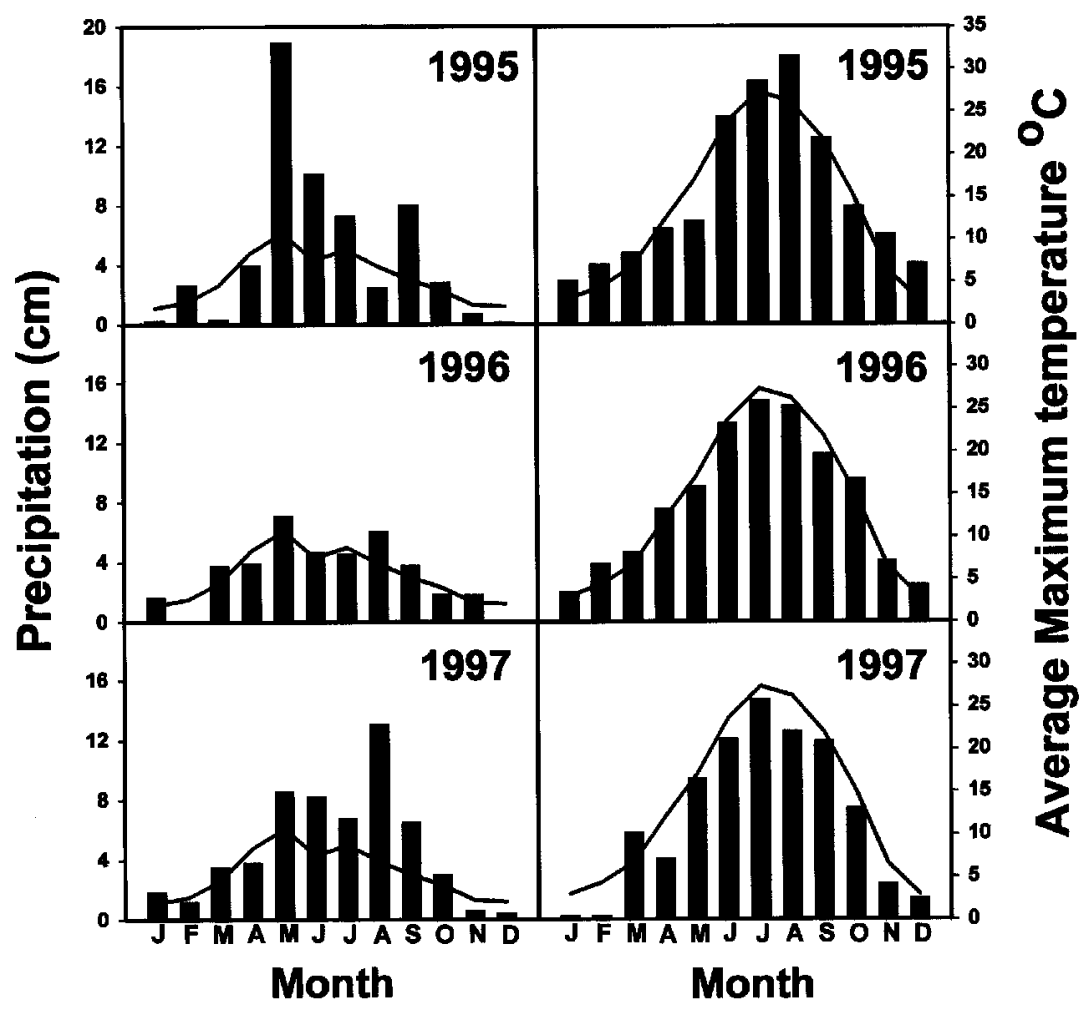

Fig. 1. Monthly total precipitation and average monthly maximum air temperatures of a mixed grass prairie site in Wyoming. The lines are long-term averages. 


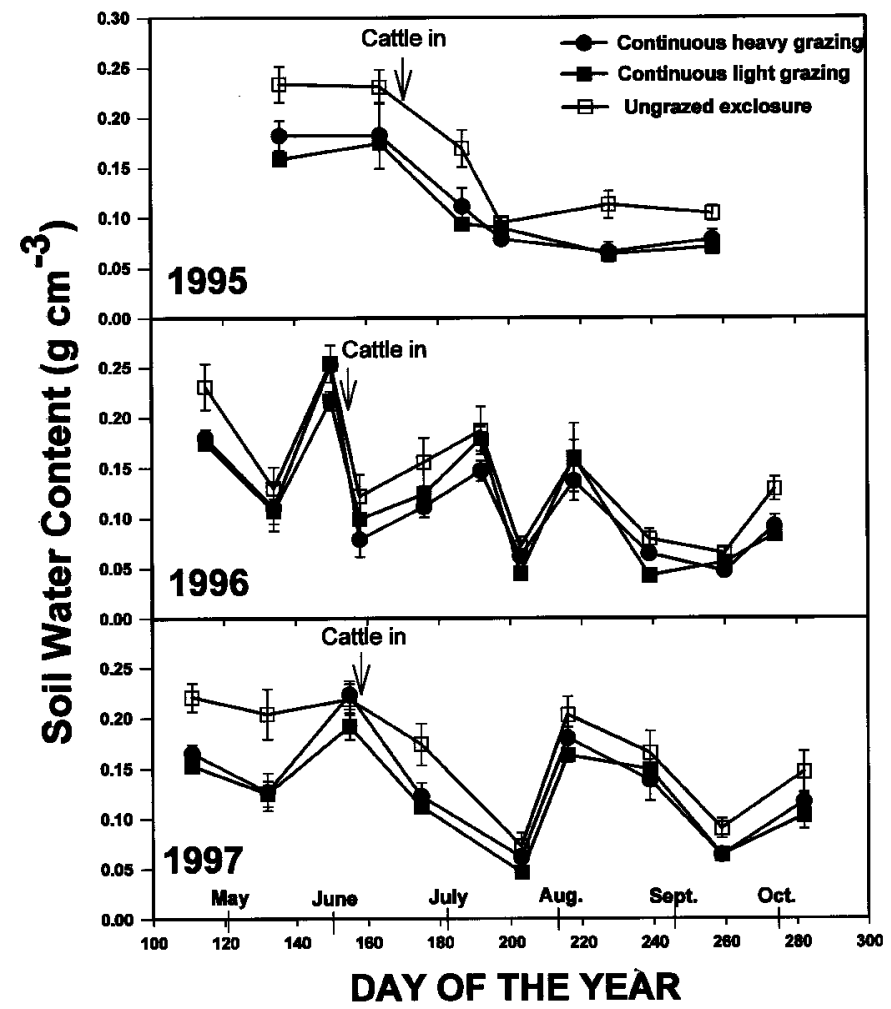

Fig. 2. Soil water content in the upper $30 \mathrm{~cm}$ of 3 mixed grass prairie pastures subjected to different grazing intensities. The $X$ axis has the first day of the month marked. Data are means of 3 replications + standard errors.

piration rate and there was little difference between the heavily and lightly grazed pastures (Fig. 3C).

In 1996 only the heavily grazed pasture had greater $\mathrm{CO}_{2}$ exchange rate than the exclosure on the first measurement date (24 April) (Fig. 4A). This trend continued for the next 2 measurement dates (13 May and 29 May), although differences were small. As in 1995, the heavily grazed pasture also had the greatest green vegetation index early in the season (Fig. 4B). Contrary to 1995 , the $\mathrm{CO}_{2}$ exchange rate and green vegetation index in the lightly grazed pasture were not higher than the exclosure in the spring of 1996. As in 1995 , once cattle were put in the pastures the green vegetation index declined slightly in the continuous heavy compared to the continuous light and exclosed pastures. $\mathrm{CO}_{2}$ exchange rate also tended to be lowest in the heavily grazed pasture during this period. During the spring of 1996 there were 2 measurement dates when soil respiration rate was slightly higher in the continuous heavy pasture than the continuous light and exclosure (day of the year 150 and 158) (Fig. 4C). There was no difference in soil respiration rate among the grazing treatments during the rest of the season.
On the first 4 measurement dates during the spring of 1997 (21 April-24 June) the $\mathrm{CO}_{2}$ exchange rate was higher in both the heavily and lightly grazed pastures compared with the exclosure (Fig. 5A). An ensuing drought caused $\mathrm{CO}_{2}$ exchange rates to drop to near zero in all pastures by mid July. $\mathrm{CO}_{2}$ exchange rates recovered following late July and early August precipitation, but there were no treatment differences for the rest of the season. Higher $\mathrm{CO}_{2}$ exchange rates in the 2 grazed pastures was again accompanied by greater green vegetation index although not on day of the year 155 (Fig. 5B). Surprisingly, green vegetation index was highest in the heavily grazed pasture on 3 dates in July and August (day of the year 203, 216, 239) but this did not result in greater $\mathrm{CO}_{2}$ exchange rate. There were 2 dates during the 1997 season when the continuous heavy pasture had a higher soil respiration rate than the continuous light and exclosed pastures (Fig. 5C). In none of the three years were treatment differences in $\mathrm{CO}_{2}$ exchange rate associated with air or soil temperature at the time of measurement (data not shown).

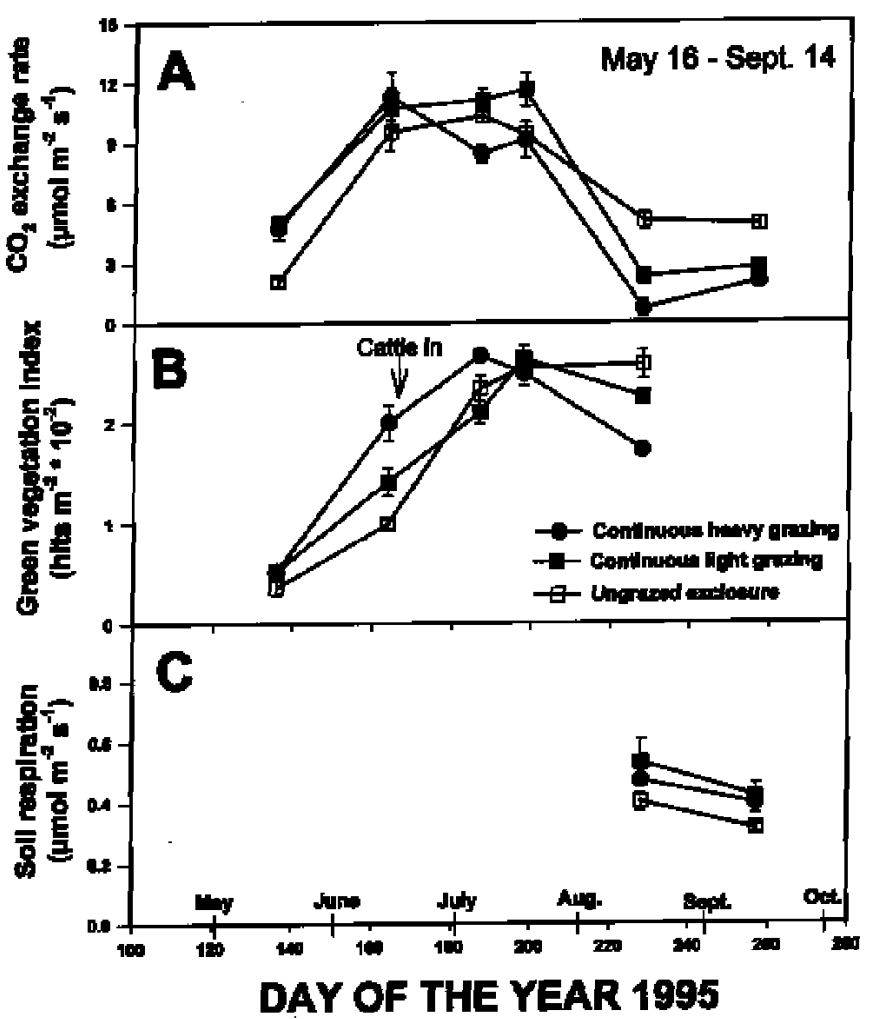

Fig. 3. 1995 data of $\mathrm{CO}_{2}$ exchange rate (corrected for soil respiration when available; $\mathrm{A}$ ), green vegetation index $(B)$ and soil respiration rate $(C)$ of 3 mixed grass prairie pastures subjected to different grazing intensities (the soil respiration equipment was not available until the final 2 dates). The $\mathbf{X}$ axis has the first day of the month marked. Data are means of 5 replications + standard errors. 


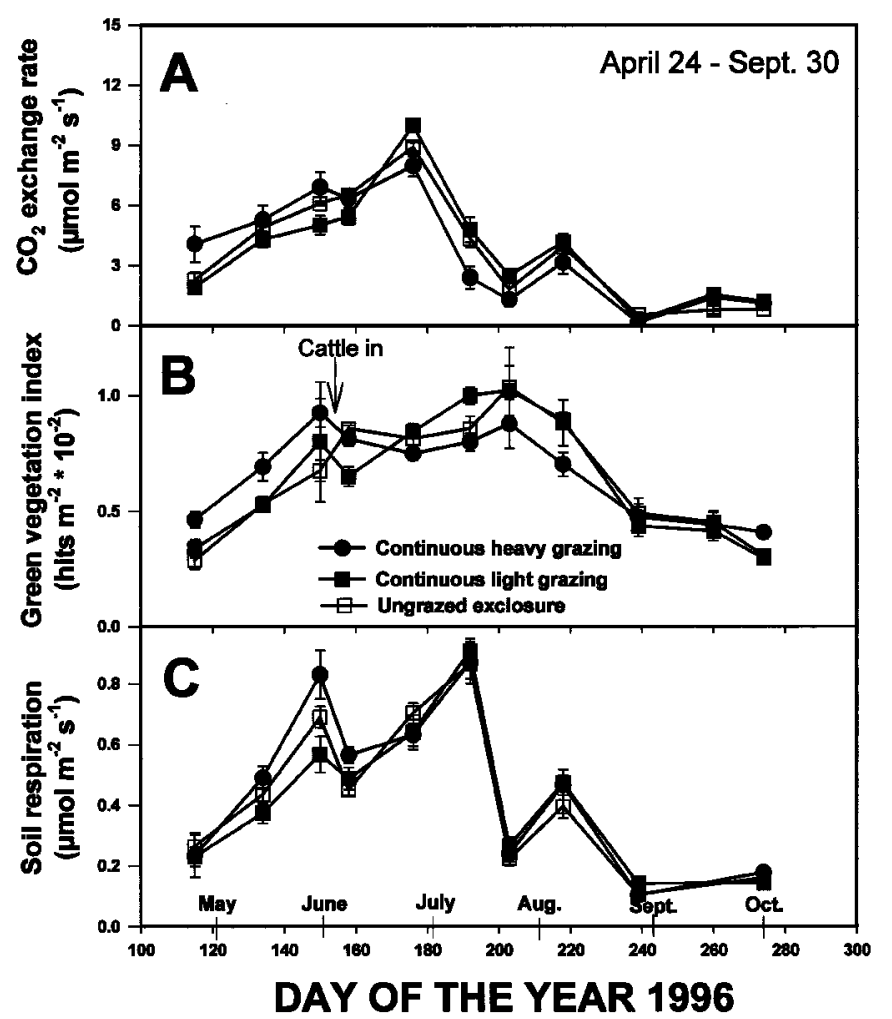

Fig. 4. 1996 data of $\mathrm{CO}_{2}$ exchange rate (corrected for soil respiration; $\mathrm{A}$ ), green vegetation index $(B)$ and soil respiration rate $(C)$ of 3 mixed grass prairie pastures subjected to different grazing intensities. The $X$ axis has the first day of the month marked. Data are means of 5 replications + standard errors.
Our data do not allow us to calculate annual net primary productivity, however, by averaging the $\mathrm{CO}_{2}$ exchange rate data over each season we can look at overall trends in carbon exchange resulting from 13 and more years of grazing. When the data are averaged over the entire season, within each year, they show no difference in the average $\mathrm{CO}_{2}$ exchange rate among these 3 grazing systems, although in 1997 there is a trend for greater $\mathrm{CO}_{2}$ exchange rate in the continuous heavy pasture, compared with exclosure (Table 1). Though the grazed pastures often had higher $\mathrm{CO}_{2}$ exchange rate early in the season, the exclosure often had equal or higher rates during mid to late season.

Since changes in species composition may affect seasonal $\mathrm{CO}_{2}$ exchange rate and soil carbon (Smoliak et al. 1972), the occurrence of the most prevalent species (as detected by the point frame) was averaged over the entire study (Table 2 ). There is relatively more blue grama in the continuous heavy and exclosed pastures than the continuous light pasture. Blue grama $\left(\mathrm{C}_{4}\right)$ appears to be replaced by the $\mathrm{C}_{3}$ species fringed sage (Artemisia frigida Willd.) and scarlet globemallow (Sphaeralcea coccinea (Nutt.) Rydb.) in the continuous light pasture. The continuous heavy pasture has less western wheatgrass than the continuous light and exclosure, but more carex (Carex eleocharis Bailey) plants. Overall, there are only small changes in species composition induced by grazing for 13 plus years. Also, no significant difference in belowground biomass was detected in these pastures (Schuman et al., 1999). Our data differ somewhat from those of Schuman et al. (1999) who measured botanical composition as a percentage of harvested peak standing crop, and found higher amounts of blue grama in the continuous heavy treatment than both the continuous light and exclosure pastures. The differences noted above may be a result of the particular placement of our $1 \mathrm{~m}^{2}$ frames in these large pastures, or that our data are averaged over many dates through the season rather than at peak standing crop.

\section{Discussion}

\section{$\mathrm{CO}_{2}$ exchange rates}

Though there was year to year variation in this study, the seasonal pattern consisted of higher $\mathrm{CO}_{2}$ exchange rates in the grazed plots (most consistently in the con-

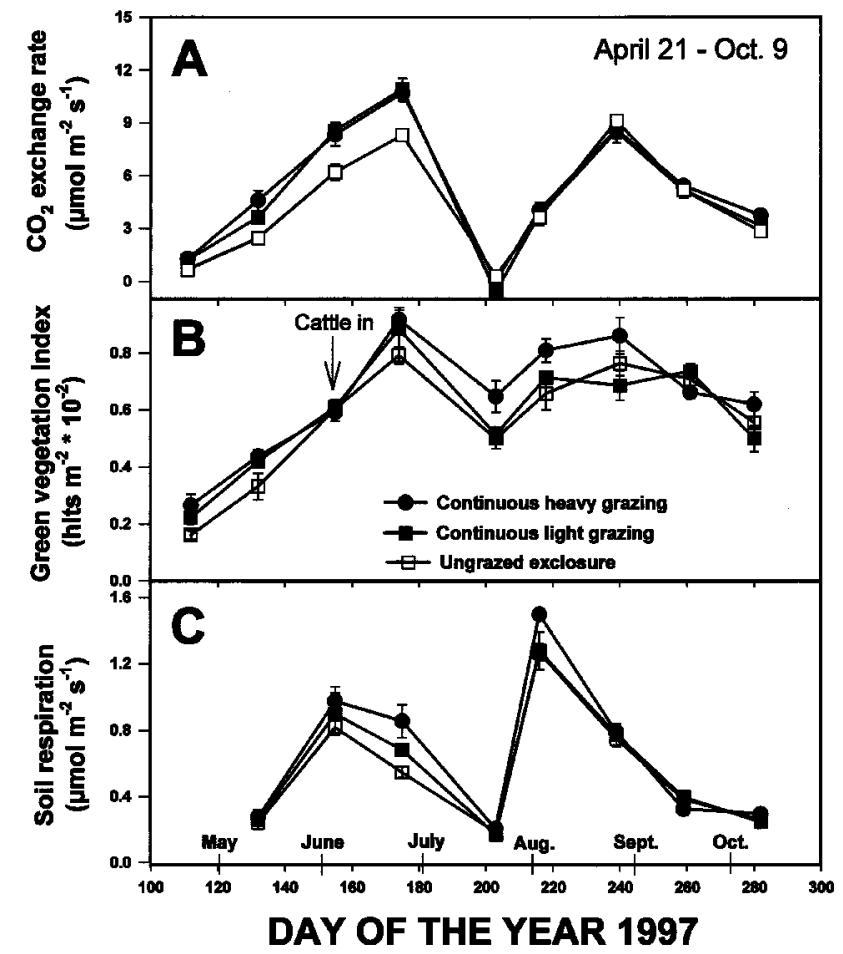

Fig. 5. 1997 data of $\mathrm{CO}_{2}$ exchange rate (corrected for soil respiration; A), green vegetation index $(B)$ and soil respiration rate $(C)$ of 3 mixed grass prairie pastures subjected to different grazing intensities. The $X$ axis has the first day of the month marked. Data are means of 5 replications + standard errors. 
Table 1. The $\mathrm{CO}_{2}$ exchange and soil respiration rates of grazed and ungrazed mixed grass prairie pastures near Cheyenne Wyoming (averaged over the entire growing season) ${ }^{1}$.

\begin{tabular}{|c|c|c|c|c|c|c|}
\hline \multirow[b]{2}{*}{ Treatment } & \multicolumn{3}{|c|}{$\mathrm{CO}_{2}$ exchange rate } & \multicolumn{3}{|c|}{ Soil respiration rate } \\
\hline & 1995 & 1996 & 1997 & 1995 & 1996 & 1997 \\
\hline & $-\ldots-\ldots$ & - - - - n & $\cdots(\mu \mathrm{r}$ & $\left.\mathrm{n}^{-2} \sec ^{-1}\right)--$ & 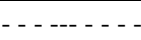 & 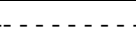 \\
\hline Continuous heavy grazing & $6.1 \pm 0.8$ & $3.9 \pm 0.4$ & $5.2 \pm 0.5$ & $0.43 \pm .02$ & $0.47 \pm .04$ & $0.66 \pm .07$ \\
\hline Ungrazed exclosure & $6.9 \pm 0.6$ & $4.0 \pm 0.4$ & $4.3 \pm 0.5$ & $0.43 \pm .04$ & $0.43 \pm . .04$ & $0.56 \pm .06$ \\
\hline
\end{tabular}

${ }^{1}$ Data are means \pm standard errors of 6,11 , and 9 measurement dates for $\mathrm{CO}_{2}$ exchange rate and 2, 10, and 8 dates for soil respiration rate in 1995,1996 , and 1997 , each of 5 replicate plots.

tinuous heavy pasture) compared with the exclosure in the spring (April, May, early June), with differences diminishing by mid June, followed by occasional higher $\mathrm{CO}_{2}$ exchange rate in the ungrazed pasture late in the season. Treatment differences in $\mathrm{CO}_{2}$ exchange rate were associated with differences in green vegetation index, indicating earlier spring green-up in the grazed pastures. There was no apparent correlation between treatment differences in $\mathrm{CO}_{2}$ exchange rate and yearly climate variation.

We did not measure litter and standing dead in this study. However, Schuman et al. (1999), using these same pastures, showed that grazing greatly reduced litter and standing dead, while in the exclosure, $72 \%$ of the above-ground phytomass was litter and standing dead. We hypothesize that earlier spring green-up (measured as higher green vegetation index) and higher $\mathrm{CO}_{2}$ exchange rates in grazed pastures is due to better light penetration and warmer microclimate conditions near the soil surface as a result of less litter and standing dead than in the ungrazed pasture. Our hypothesis is supported by Bremer et al. (1998), who attributed warmer soil temperature in clipped vs. unclipped plots to improved radiation penetration resulting from less litter and standing dead. We were unable to measure canopy light penetration in our system, as it is very difficult to assess accurately where plant canopy structure is low. Summarizing over the 3year period of this study, we conclude that these intensities of grazing do not have a large effect on daytime carbon exchange of the mixed-grass prairie of Wyoming.

\section{Soil respiration rate}

When examined on a seasonal basis, we found no difference in soil respiration rate in grazed vs. ungrazed pastures (Table 1), but there were several dates over the 3 years when soil respiration rate was higher in the grazed vs. ungrazed pastures. These results differ from Bremer et al. (1998) who reported reduced soil respiration in grazed vs. ungrazed tallgrass prairie. In that study the reduction in photosynthetic surface area and available carbohydrates was reported to be the dominating factor in lowered respiration rates. In our ecosystem, photosynthesis was actually higher in the grazed pastures early in the season. Therefore, higher soil respiration rates in the spring may be indicative of greater carbon allocation to roots. Our maximum soil respiration rates were about $10 \%$ of those of the tallgrass prairie, indicating very different soil microbial and root respiration activity between tallgrass and mixed grass prairie ecosystems.

\section{Green vegetation index and species composition}

It was surprising in 1997 not to see a decrease in $\mathrm{CO}_{2}$ exchange rate and green vegetation index in the heavily grazed pasture after cattle were put in the pasture. The introduction of cattle was followed by a severe drought period in 1997 (Fig. 2). Plant responses to drought, rather than grazing treatment, may have been the overriding factor in any treatment differences measured during and following the drought period in 1997.

There was no apparent relationship between the small differences in species composition in these pastures and the seasonal trends in $\mathrm{CO}_{2}$ exchange rate. In a similar study (LeCain et al. 1998), conducted on the shortgrass prairie of eastern Colorado, long-term grazing elicited a shift in species composition to a greater dominance of blue grama. The prevalence of this warm-season grass was related to higher $\mathrm{CO}_{2}$ exchange rate in the grazed pastures when warm temperatures occurred, while the exclosure, with a greater percentage of cool-season species, had higher $\mathrm{CO}_{2}$ exchange rate when weather was cool. No such relationship was seen in the mixed grass prairie study. However, shifts in species composition in these pastures are likely to be more of a factor in the future (Schuman et al. 1999).

\section{Effects of $\mathrm{CO}_{2}$ exchange and soil respiration rates on soil carbon}

Our data show only small differences in $\mathrm{CO}_{2}$ exchange rate and soil respiration rate between grazed and exclosed pastures when the rates are averaged within each year (Table 1), suggesting little effect of grazing on soil carbon concentration in our study. However, our ability to make conclusions about effects of carbon

Table 2. The relative abundance ${ }^{1}$ of major species on grazed and ungrazed mixed grass prairie pastures near Cheyenne Wyo., as determined by the point frame method.

\begin{tabular}{lccc}
\hline \hline & \multicolumn{2}{c}{ Grazing intensity } & Ungrazed \\
\cline { 2 - 3 } Species & Continuous heavy & Continuous light & $36.5 \pm 3$ \\
Blue grama (Bouteoloua gracilis (H.B.K.) Lag. Ex Steud.) & $37.0 \pm 3$ & $25.3 \pm 2$ & $22.8 \pm 2$ \\
Western Wheatgrass (Pascopyrum smithii (Rydb.) A. Love) & $10.5 \pm 1.5$ & $22.9 \pm 2$ & $8.1 \pm 0.9$ \\
Carex (Carex eleocharis Bailey) & $15.0 \pm 1$ & $3.6 \pm 0.6$ & $6.0 \pm 0.8$ \\
Fringed Sage (Artemisia frigida Willd.) & $8.1 \pm 0.5$ & $26.0 \pm 2$ & $5.0 \pm 0.5$ \\
Scarlet globemallow (Sphaeralcea coccinea (Nutt.) Rydb.) & $3.2 \pm 0.3$ & $12.0 \pm 1$ & $6.0 \pm 0.9$ \\
Needle-and-thread grass (Stipa comata Trin and Rupr.) & $3.2 \pm 0.3$ & $2.0 \pm 0.3$ & \\
\hline
\end{tabular}

Relative abundance is the percentage of point frame "hits" over 3 years worth of data on 5 replicate plots (125 measurements) \pm standard error. 
exchange on soil carbon are limited because our measurements were performed at 3 week intervals through the season and only during periods of maximum daily photosynthesis. We do not know the proportion of spring days during which grazed plots had higher $\mathrm{CO}_{2}$ exchange rates, nor how many days during the summer that $\mathrm{CO}_{2}$ exchange rate was lower in the continuous heavy plots, nor if treatment differences seen at midday occur diurnally.

The influence of observed seasonal trends in $\mathrm{CO}_{2}$ exchange rate on soil carbon depends on interactive effects of grazing and rainfall on $\mathrm{CO}_{2}$ exchange rate and seasonal patterns of partitioning of photosynthate between above and below-ground organs. On the northern mixed grass prairie most of the above-ground production typically occurs prior to July when soil moisture and temperature are favorable for growth of the dominant $\mathrm{C}_{3}$ species (Sims and Singh 1978a, also see green vegetation index in Figs. 3, 4, and $5)$. Although a direct effect of grazing is to decrease carbon allocation to the roots during above-ground regrowth (Caldwell et al. 1981, Detling et al. 1979) much of the period of higher $\mathrm{CO}_{2}$ exchange rate which we measured in grazed pastures occurred before cattle were introduced. Higher $\mathrm{CO}_{2}$ exchange rate and productivity in grazed vs. ungrazed pastures during this part of the season are likely accompanied by greater carbon allocation to the roots. Over time this could increase soil carbon concentration. There was also a trend for greater soil respiration in the grazed compared to the ungrazed pastures early in the season, particularly in the heavily grazed pasture. This is another indication of improved biological activity and greater carbon allocation to roots during the early part of the season in grazed pastures, probably because of warmer soil temperature (Bremer et al. 1998).

In typical years, soils dry out as the season progresses and $\mathrm{CO}_{2}$ exchange rate and plant productivity slows. The $\mathrm{CO}_{2}$ exchange rate declines as defoliation by grazers lowers the photosynthetic surface area. This suggests less below-ground carbon allocation in grazed vs. ungrazed pastures during the later part of the season. However, much of the mid- to late-season photosynthate in range grasses is used in storage, rather than shoot or root growth, as plants prepare for summer or winter dormancy (White 1973). Most late season carbohydrates are stored in the stem bases and crowns and are utilized in winter respiration and leaf tissue regeneration in early spring (White 1973). Therefore, these carbon compounds may have less effect on soil carbon concentration than carbon used for structural root growth early in the season (Dormaar and Sauerbeck 1983). Further studies are necessary to determine precisely how seasonal differences in $\mathrm{CO}_{2}$ exchange rate and soil respiration influence soil carbon in this ecosystem.

\section{Conclusion}

Our expectation that seasonal $\mathrm{CO}_{2}$ exchange rate would be associated with the amount of green vegetation in the pastures was largely confirmed in this study. However, the discovery of higher $\mathrm{CO}_{2}$ exchange rate and earlier spring green-up in grazed pastures was unanticipated, and perhaps the most interesting find. Overall, our data show that cattle grazing, at the intensities used in this study, elicits only small changes in ecosystem carbon exchange, soil respiration rate, green vegetation production and species composition. These results agree with studies conducted on the nearby shortgrass prairie, where the ecosystem has been found to be very tolerant of cattle grazing. Semiarid grasslands with a long history of grazing respond to grazing with only small changes in annual net primary productivity and community composition (Milchunas et al. 1988, Milchunas and Lauenroth 1993). In both systems up to $90 \%$ of the plant based carbon is below-ground (Schuman et al. 1999, Milchunas et al. 1998). Therefore, removal of even $50 \%$ of the above-ground plant material (as in the continuous heavy treatment) has only a small effect on ecosystem functioning.

\section{Literature Cited}

Angell, R. and T. Svejcar. 1999. A chamber design for measuring net $\mathrm{CO}_{2}$ exchange on rangeland. J. Range Manage. 52:27-31.

Bauer, A., C.V. Cole and A.L. Black. 1987. Soil property comparisons in virgin grasslands between grazed and nongrazed management systems. Soil Sci. Soc. Amer. J. 51:176-182.

Berg, W.A., J.A. Bradford, and P.L. Sims. 1997. Long-term soil nitrogen and vegetation change on sandhill rangeland. J. Range Manage. 50:482-486.

Bremer, D.J., J.M. Ham, C.E. Owensby and A.K. Knapp. 1998. Responses of soil respiration to clipping and grazing in a tallgrass prairie. J. Environ. Qual. 27:1539-1548.
Caldwell, M.M., J.H. Richards, D.A. Johnson, R.S. Nowak, and R.S. Dzurec. 1981. Coping with herbivory: Photosynthetic capacity and resource allocation in two semiarid Agropyron bunchgrasses. Oecologia 50:14-24.

Detling, J.K., M.I. Dyer, and D.T. Winn. 1979. Net photosynthesis, root respiration and regrowth of Bouteloua gracilis following simulated grazing. Oecologia 41:127-134.

Detling, J.K., W.J. Parton, and H.W. Hunt. 1978. An empirical model for estimating $\mathrm{CO} 2$ exchange of Bouteloua gracilis (H.B.K.) Lag. in the shortgrass prairie. Oecologia 33:137-147.

Dormaar, J.F. and D.R. Sauerbeck. 1983. Seasonal effects on photoassimilated carbon14 in the root system of blue grama and associated soil organic matter. Soil Biol. Biochem. 15:475-479.

Dormaar, J.F. and W.D. Willms. 1998. Effect of forty years of grazing on fescue grassland soils. J. Range Manage. 51:122-126.

Hart, R.H., M.J. Samuel, P.S. Test, and M.A. Smith. 1988. Cattle, vegetation and economic responses to grazing systems and grazing pressure. J. Range Manage. 41:282-286.

Hazlett, D.L. 1992. Leaf area development of four plant communities in the Colorado steppe. Amer. Midl. Nat. 127:276-289.

LeCain, D.R., J.A. Morgan, G.E. Schuman, J.D. Reeder, and R.H. Hart. 1998. Cattle grazing and carbon assimilation in the shortgrass steppe of eastern Colorado. American Society of Agronomy abstracts. Baltimore, Md. October, 1998.

Manley, J.T., G.E. Schuman, J.D. Reeder and R.H. Hart. 1995. Rangeland soil carbon and nitrogen responses to grazing. J. Soil and Water Cons. 50:294-298.

McNaughton, S.J. 1979. Grazing as an optimization process: Grass-ungulate relationships in the serengeti. The American Naturalist. 113:691-703.

MeNaugton, S.J., D.G. Milchunas, and D.A. Frank. 1996. How can net primary productivity be measured in grazing ecosystems? Ecology 77:974-977.

Milchunas, D.G. and W.K. Lauenroth. 1993. Quantitative effects of grazing on vegetation and soils over a global range of environments. Ecol. Mono. 63:327-366.

Milchunas, D.G., W.K. Lauenroth and I.C. Burke. 1998. Livestock grazing: animal and plant biodiversity of shortgrass steppe and the relationship to ecosystem functioning. Oikos 83:65-74.

Milchunas, D.G., O.E. Sala, and W.K. Lauenroth. 1988. A generalized model of the effects of grazing by large herbivores on grassland community structure. The Amer. Naturalist 132:87-106.

Morgan, J.A. and R.H. Brown. 1983. Photosynthesis and growth of Bermudagrass swards. II. Growth patterns as estimated by harvest and gas exchange techniques. Crop Sci. 23:352-357.

Painter, E.L. and J.K. Detling. 1981. Effects of defoliation on net photosynthesis and regrowth of western wheatgrass. J. Range Manage. 34:68-71. 
Ruess, R.W. and S.J. McNaughton. 1987. Grazing and the dynamics of nutrient and energy regulated microbial processes in the Serengeti grasslands. Oikos 49:101-110.

Schuman, G.E., J.D. Reeder, J.T. Manley, R.H. Hart, and W.A. Manley. 1999. Impact of grazing management on the carbon and nitrogen balance of a mixed-grass prairie. Ecol. Appl. 9:65-71.

Shaw, J.H. 1995. How many bison originally populated western rangelands? Rangelands 17:148-150.
Sims, P.L. and J.S. Singh. 1978a. The structure and function of ten western North American grasslands II. Intra-seasonal dynamics in primary producer compartment. J. Ecol. 66:547-572.

Sims, P.L. and J.S. Singh. 1978b. The structure and function of ten western North American grasslands III. Net primary production, turnover and efficiencies of energy capture and water use. J. Ecol. 66:573-597.

Smoliak, S., J.F. Dormaar, and A. Johnston. 1972. Long-term grazing effects on Stipa-Bouteloua prairie soils. J. Range Manage. 25:246-250.
Stebbins, G.L. 1981. Coevolution of grasses and herbivores. Ann. Missouri Bot. Gard. 68:75-86.

Wallace, L.L. 1990. Comparative photosynthetic responses of big bluestem clipping versus grazing. J. Range Manage. 43:58-61.

Warren-Wilson, J. 1963. Estimation of foliage denseness and foliage angle by inclined point quadrats. Aust. J. Bot. 11:95-105.

White, L.M. 1973. Carbohydrate reserves in grasses: a review. J. Range Manage. 26:13-18. 


\title{
Alkaloid levels of a tall larkspur species in southwestern Alberta
}

\author{
W. MAJAK, R.E. MCDIARMID, J.W. HALL, AND W. WILLMS
}

Authors are toxic plant biochemist and research technician, Agriculture and Agri-Food Canada (AAFC), Range Research Unit, Kamloops, B.C. V2B 8A9; statistician, $A A F C$, Summerland, B.C. VOH 1ZO; and range ecologist, AAFC, Lethbridge, AB T1J $4 B 1$.

\begin{abstract}
Tall larkspurs (Delphinium spp.) are widely distributed in western North America and they kill more cattle on rangelands than any other poisonous plant. In Alberta, Canada, D. brownii Rydb. has a long history of causing cattle poisoning. The neurotoxic norditerpenoid alkaloid methyllycaconitine (MLA) was first detected in D. brownii over 50 years ago. A 2-year (1996 to 1997) survey was conducted on the levels of MLA in D. brownii collected at 5 sites in the foothills of southwestern Alberta. The vegetative stage of growth yielded the highest levels of MLA and the decline and change in concentration during that interval could be predicted on the basis of Julian day alone. The MLA levels during bud to pod development were not significantly different but they exceeded the reported levels for MLA in low larkspur by 5to 10-fold. A new method is described for the determination of MLA by HPLC.
\end{abstract}

Key Words: Poisonous plants, Delphinium brownii, neurotoxic alkaloids, methyllycaconitine

Larkspur (Delphinium spp.), especially the tall larkspurs, constitute the most serious poisonous plant problem to rangeland cattle in North America (Nielson and Ralphs 1998, Wroe and Smith 1991, Fowler et al. 1982). Four species of tall larkspur predominate in western USA: D. barbeyi Huth, D. glaucescens Rydb., D. occidentale S. Wats., and D. glaucum S. Wats. (Ralphs et al. 1997). A large geographically separate population of D. glaucum also occurs in northwestern Saskatchewan (SK) and Alberta (AB), extending through northern British Columbia (B.C.), the Yukon, Western Mackenzie and Alaska (Brayshaw 1989). The 2 populations of D. glaucum are sometimes treated as distinct species (Hitchcock and Cronquist 1964). The population in the Pacific States is referred to as D. glaucum (mountain larkspur) and that in Alaska and Canada as D. brownii Rydb. (tall delphinium). According to Brayshaw (1989), the morphological features that separate them on a taxonomic basis are minor and indistinct and he does not treat them as separate species and all modern Floras of Alaska, Yukon, Northwest Territories, B.C., $\mathrm{AB}, \mathrm{SK}$ agree. However, the chemical literature on tall larkspur in Canada always refers to D. brownii, so we have chosen to retain the 2 species concept.

The authors would like to thank Michael Benn, Garry Manners and Dale Gardner for providing alkaloid standards, Harriet Douwes for collecting plant samples, and Blair Surridge for technical assistance. This manuscript is dedicated to the late Dr. Robert T. Ogilvie for his contributions to the study of poisonous plants in Western Canada.

Manuscript accepted 30 May 1999.

\section{Resumen}

"Tall larkspurs" (Delphinium spp.) están ampliamente distribuidas en el oeste de Norte américa, y ellas matan mas ganado en los pastizales que ningún otra especie de planta tóxica. En Alberta, Canadá, $D$. brownii tiene un largo historial como causante de la muerte de ganado por envenenamiento. El alcaloide neurotóxico norditerpenoide metilicaconitina (MLA) fue detectado por primera vez en $D$. brownii hace 50 años. Se condujo un examen de dos años (1996 a 1997) de los niveles de MLA en $D$. brownii colectado en 5 sitios al pie de las montañas del sudoeste de Alberta. Los más altos niveles de MLA se registraron cuando la planta estaba en la etapa vegetativa de crecimiento y la disminución y cambio en la concentración durante ese intervalo pudieron ser predichas en base solo a los días julianos. Los niveles de MLA durante el desarrollo de yemas y vainas no fueron significativamente diferentes, pero ellos excedieron entre 5 y 10 veces los valores de MLA reportados en "Low larkspur". Se describe un nuevo método para la determinación de MLA por medio de HPLC.

The detection of methyllycaconitine (MLA) in D. brownii occurred over 50 years ago (Manske 1938, Marion and Manske 1946). The proof of structure (Benn et al. 1963), the precise stereochemistry (Pelletier et al. 1981, Edwards and Przyblyska 1982) and the mode of action of the alkaloid (Aiyar et al. 1979, Nation et al. 1982) were subsequently elucidated. It is now well established that MLA is the principal neurotoxic alkaloid in most native species of Delphinium in North America (Manners et al. 1991, 1993, Majak 1993). The objectives of this study were 1) to develop a new method for MLA determination by HPLC since earlier column packings for MLA determinations on HPLC (Manners and Pfister 1993, Majak et al. 1987) were not readily available and 2) to compare MLA levels in D. brownii at different stages of growth and at different sampling sites in southwestern Alberta where cattle losses due to the ingestion of D. brownii can be severe.

\section{Materials and Methods}

The 5 sampling sites were located between Bow Crow Forest $\left(49^{\circ} 51^{\prime} \mathrm{N}, 114^{\circ} 0^{\prime} \mathrm{W}\right)$ and the $\mathrm{OH}$ Ranch $\left(50^{\circ} 35^{\prime} \mathrm{N}, 114^{\circ} 21^{\prime} \mathrm{W}\right)$ in the fescue (Festuca campestris Rydb.)-aspen (Populus tremu loides Michx.) parkland of southwestern Alberta, commonly known as the foothills. The elevations at the sites ranged from 1,400 to $1,600 \mathrm{~m}$ and the soils were loamy and characterized as Dark Gray Chernozem (Boralfic Boroll). 
Composite samples of D. brownii (100-200 g fresh weight, aerial portions) representing sequential stages of growth (vegetative, bud, flower, and pod) were collected randomly at each site during 2 growing seasons $(\mathrm{n}=26$ in 1996 and $\mathrm{n}=$ 31 in 1997). The number of samples at each stage of growth varied with site and year, depending on the duration of the phenological stage. When the larkspur plants became elongated and stemmy, the upper $50 \mathrm{~cm}$ of the shoot containing most of the leaves and the inflorescence was excised for analysis. The samples were freeze-dried, the alkaloids were extracted as described previously (Majak et al. 1987) and the extracts analyzed by HPLC utilizing a polymeric reverse phase column (PRP-1, 150 x $4.1 \mathrm{~mm}$, Hamilton Co., part no. 79444) and acetonitrile $0.1 \%$ phosphoric acid, 23:77, as the isocratic developing solvent at a flow rate of $1.8 \mathrm{ml} / \mathrm{min}$ with UV detection at $212 \mathrm{~nm}$. The PRP-1 column minimized tailing of alkaloidal compounds without the use of ion-pairing reagents (Majak et al. 1987), which can accumulate as residues and affect instrument performance. The alkaloid was quantified by the external standard method with duplicate injections per plant sample using a $20 \mu 1$ sample loop.

The effects of site and stage of growth on MLA concentration (\% by weight) were determined by analysis of variance, or co-variance using the procedures of the SAS Institute Inc. (1989). Years were considered a form of replication. The data were transformed to logarithms for analysis to provide homogeneity of variance. Concentrations varied with collection date during the vegetative stage but not during the bud, bloom, or pod stages. For this reason, the data from the vegetative stage were analysed separately from the data for the other 3 stages. For the vegetative stage, the sources of variation in the analysis of co-variance were site, year, site $\mathrm{x}$ year, Julian day (co-variate) and the residual error. A test for non-parallelism at different sites and years was also carried out. For the bud, bloom, and pod data, the sources of variation in the analysis of variance were stage, site, stage $\mathrm{x}$ site, year, year $\mathrm{x}$ site $\mathrm{x}$ stage (experimental error, includes year $\mathrm{x}$ site and year $\mathrm{x}$ stage) and the residual error. Least squares estimates of $\log$ (MLA) concentration were made for each stage, site and year and back transformed for presentation. As is appropriate for back transformed logarithmic data, the variability was indicated by the coefficient of variation of the mean. This is the standard error divided by the mean and expressed as a percentage.

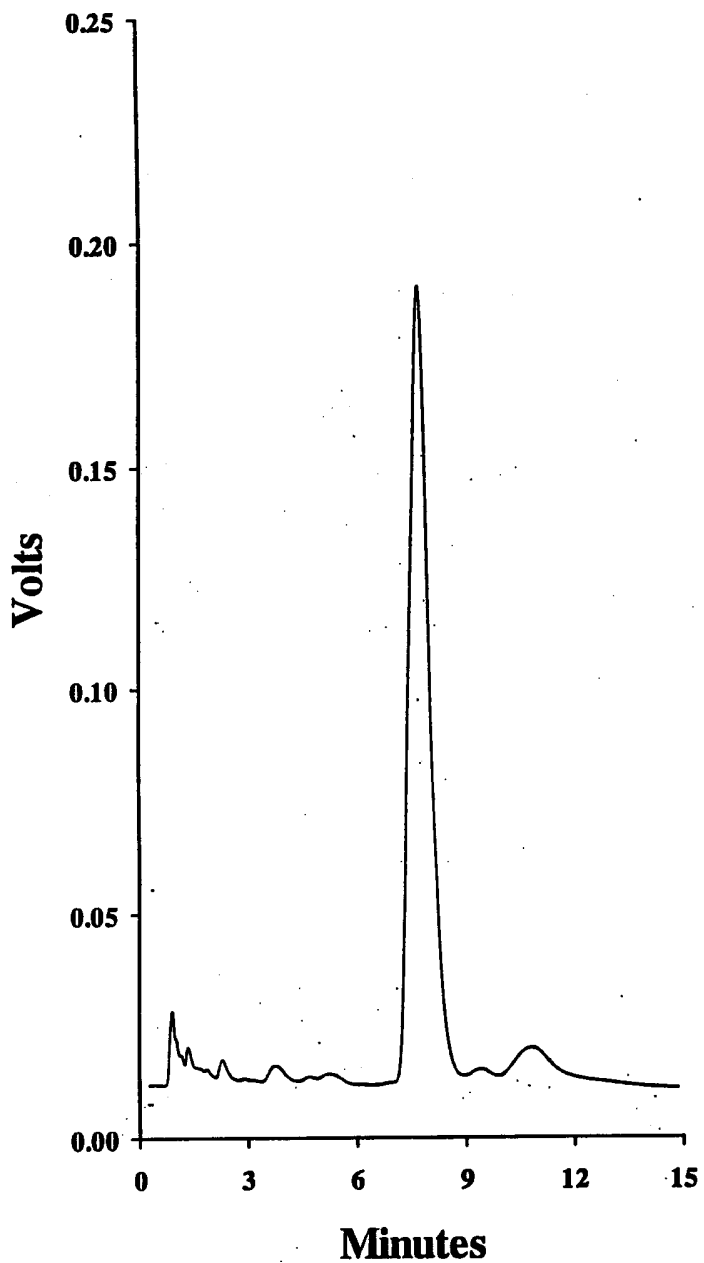

Fig. 1. HPLC separation of MLA $(320 \mathrm{ppm})$ from a purified extract of freeze-dried $D$. brownii (0.5 g). Column: Hamilton PRP-1 (150 x $4.1 \mathrm{~mm})$. Detection: $212 \mathrm{~nm}$. Mobile phase: acetonitrile $-0.1 \%$ phosphoric acid (23:77).

\section{Results and Discussion}

The detection limit for MLA on the PRP-1 column was $<10$ ppm and the resolution on HPLC was equal to that described previously (Majak et al. 1987). For example, MLA (retention time $=7.4$ min) was separated from nudicauline (retention time $=8.6 \mathrm{~min}$ ) with near baseline resolution. Nudicauline differs from MLA only at $\mathrm{C}_{14}$ where MLA has a methoxy group and nudicauline has an acetyl group. In agreement with earlier studies (Benn et al. 1963) and as evidenced by the single peak on HPLC (Fig. 1), MLA was the major anthranoyl-type norditerpenoid alkaloid thus far detected in $D$. brownii. It is possible that geyerline and grandiflorine, previously reported in D. glaucum (Manners et al. 1998) were also present in D. brownii but only in trace quantities. These alkaloids were also resolved in our HPLC system.
The norditerpenoid alkaloids, browniine (Benn et al. 1963) and browniine acetate (Aiyar et al. 1978) have also been isolated from $D$. brownii, but these alkaloids would not be visualized by UV detection on HPLC owing to the absence of the anthranoyl-group. The absence of this group also renders these alkaloids much less toxic than MLA (Benn and Jacyno 1983, Manners et al. 1993). Ralphs et al. (1997) reported on the concentration of total toxic anthranoyl-type norditerpenoid alkaloids in D. glaucum (mountain larkspur) but they did not specify on the proportion of MLA. They concluded however, that of the 4 species of tall larkspur that were examined in the USA, D. glaucum had the highest levels of toxic norditerpenoid alkaloids: $1 \%$ on a dry matter basis with the range extending from 0.5 to $2 \%$.

The highest levels of MLA in D. brownii occurred during the vegetative stage of growth and the levels extended from 1 to $5 \%$. These MLA levels were at least 2- to 
Table 1. Levels of MLA (\% by weight) in tall larkspur averaged for each stage, site, and year.

\begin{tabular}{|c|c|c|c|c|c|c|c|c|c|c|c|c|}
\hline \multicolumn{4}{|c|}{ Stage } & \multicolumn{6}{|c|}{ Site } & \multicolumn{3}{|c|}{ Year } \\
\hline Bud & Bloom & Pod & $\mathrm{CV}^{1}$ & 1 & 2 & 3 & 4 & 5 & $\mathrm{CV}$ & 1996 & 1997 & $\mathrm{CV}$ \\
\hline
\end{tabular}

10-fold greater than those reported for low larkspur (D. nuttallianum) at the same stage of growth (Majak 1993). This may well account for the much higher incidence of larkspur poisoning in the foothills of Alberta than in the southern interior of B.C. where low larkspur is widespread but tall larkspur is absent. Tall larkspur is also seasonally persistent as compared to low larkspur, which is seasonally ephemeral. Field observations on grazing cattle in Canada suggest that the larkspurs are a preferred species during the vegetative stages of growth (Majak and Engelsjord 1988, B. Maynard, personal communication, $\mathrm{OH}$ Ranch).

During the vegetative stage, there was a significant $(\mathrm{P}<0.0001)$ decline in MLA levels with time. The relationship between log concentration of MLA and time (Julian days after January 1) during the vegetative stage of D. brownii could be expressed as:

$$
\ln [\mathrm{MLA}]=6.1059-0.0310 \text { (days) (1) }
$$

where $\mathrm{r}^{2}=0.79, \mathrm{SE}$ (intercept) $=0.5824$ and SE (regression coefficient) = 0.003465. During 1996 and 1997, the vegetative stage in $D$. brownii began at the end of May and ended during the beginning of July. The rate of decline was the same for all sites and years (no significant non-parallelism). On average, the MLA concentration declined by about $3 \%$ of its value each day. There were no significant differences in the intercepts among sites or among years.

During bud, bloom, and pod development, there were no significant differences in MLA levels among stages of growth or among sites at those stages but average values for MLA were higher in 1997 than in 1996 (Table 1). The levels of MLA in D. brownii at the more advanced stages of growth were still 5- to 10-fold higher than those reported for low larkspur (Majak 1993, Pfister and Gardner 1998). This again underlines the much greater toxicity of this species of tall larkspur.

The rainfall in the study area during July and August, 1996, which was the bud to pod growing period, was 5 to $10 \%$ of normal. The rainfall for the same period in 1997 was closer to normal. Whether this difference in moisture affected the MLA levels in D. brownii is not known. There are only a few reports on the effect of moisture stress on tall larkspur toxicity and they are inconsistent. Olsen et al. (1990), using a mouse bioassay, reported no difference in the toxicity of D. occiden tale collected from a moist site and a dry site. Ralphs et al. (1997) compared toxic alkaloid levels in tall larkspur growing in shaded and unshaded areas. The alkaloid levels in $D$. barbeyi were higher $(\mathrm{P}<0.02)$ at the open site but significant differences were not detected in the alkaloid levels of D. occidentale from the 2 types of sites. In low larkspur, a seasonally ephemeral species, lower levels of MLA were associated with site conditions that reduced soil moisture stress (Majak et al. 1999). It is possible that moisture conditions affect alkaloids in climax species, such as tall larkspur, differently and more studies are required to resolve this issue.

In summary, a reliable method was developed for the analysis of MLA in $D$. brownii by HPLC. The vegetative stage of growth yielded the highest levels of MLA and the change and decline in concentration during that period could be predicted from Julian day alone. The MLA levels during bud to pod development did not show significant changes, nor were there differences in MLA levels among sites. The MLA levels in D. brownii, a tall larkspur, can be 5-to 10-fold higher than in $D$. nuttallianum, a low larkspur, and this may account for the much higher incidence of cattle poisoning from tall larkspur than from low larkspur ingestion in Western Canada.

\section{Literature Cited}

Aiyar, V.N., M. Benn, Y.Y. Huang, J.M. Jacyno, and A.J. Jones. 1978. The alkaloids of Delphinium brownii. Phytochemistry 17:1453-1454.

Aiyar, V.N., M.H. Benn, T. Hanna, J. Jacyno, S.H. Roth, and J.L. Wilkens. 1979. The principal toxin of Delphinium brownii Rydb., and its mode of action. Experientia 35:1367-1368.
Benn, M.H. and J.M. Jacyno. 1983. The toxicology and pharmacology of diterpenoid alkaloids. In S.W. Pelletier (ed.) Alkaloids: Chemical and biological perspectives. Vol. 1. John Wiley and Sons Inc., New York, N.Y.

Benn, M.H., M.A.M. Cameron, and O.E. Edwards. 1963. The alkaloids of Delphinium brownii Rydb. The structure of browniine. Can. J. Chem. 41:477- 482.

Brayshaw, T.C. 1989. Buttercups, waterlillies and their relatives in British Columbia. Royal British Columbia Museum, Victoria, B.C.

Edwards, O.E. and M. Przybylska. 1982. The lycoctonine family of alkaloids: a stereochemical revision. Can. J. Chem. 60:2661-2667.

Fowler, M., A.L. Craigmill, B.B. Norman, and $P$. Michelsen. 1982. Livestock Poisoning Plants of California. Leaflet 21268. Division of Agric. Sci. Univ. of Calif., Davis, Calif. 23 p.

Hitchcock, C.L. and A. Cronquist. 1964. Vascular Plants of the Pacific Northwest. Part 2: Salicaceae to Saxifragaceae. University of Wash. Press, Seattle, Wash.

Majak, W. 1993. Alkaloid levels in a species of low larkspur and their stability in rumen fluid. J. Range Manage. 46:100-104.

Majak, W. and M. Engelsjord. 1988. Levels of a neurotoxic alkaloid in a species of low larkspur. J. Range Manage. 41:224-226.

Majak, W., R.E. McDiarmid, and M.H. Benn. 1987. Isolation and HPLC determination of methyllycaconitine in a species of low larkspur (Delphinium nuttallianum). J. Agr. Food Chem. 35:800-803.

Majak, W., A.L. van Ryswyk, and J.W. Hall. 1999. Soil moisture influences low larkspur and death camas alkaloid levels. J. Range Manage. 52:127-131.

Manners, G.D., J.A. Pfister, M.H. Ralphs, K.E. Panter, and J.D. Olsen. 1991. Larkspur chemistry: toxic alkaloids in tall larkspurs. J. Range Manage. 45:63-67.

Manners, G.D., K.E. Panter, J.A. Pfister, J.H. Ralphs, and L.F. James. 1998. The characterization and structure-activity evaluation of toxic norditerpenoid alkaloids from two Delphinium species. J. Nat. Prod. 61:1086-1089.

Manners, G.D. and J.A. Pfister. 1993. Normal phase liquid chromatographic analysis of toxic norditerpenoid alkaloids. Phytochem. Anal. 4:14-18. 
Manners, G.D., K.E. Panter, M.H. Ralphs, J.A. Pfister, J.D. Olsen, and L.F. James. 1993. Toxicity and chemical phenology of norditerpenoid alkaloids in the tall larkspurs. J. Agr. Food Chem. 41: 96-100.

Manske, R.H.F. 1938. An alkaloid from Delphinium brownii Rydb. Can. J. Res. B. 16:57-60.

Marion, L. and R.H.F. Manske. 1946. Identity of the hydrolytic base obtained from Delphinium brownii Rydb. with lycoctonine. Can. J. Research B. 24:1- 4.

Nation, P.N., M.H. Benn, S.H. Roth, and J.L. Wilkens. 1982. Clinical signs and studies of the site of action of purified larkspur alkaloid, methyllycaconitine, administered parenterally to calves. Can. Vet. J. 23:264-266.
Nielsen, D.B. and M.H. Ralphs. 1988. Larkspur: economic considerations, $\mathrm{p}$. 119-129. In L.F. James, M.H. Ralphs, and D.B. Nielsen (eds.) The ecology and economic impact of poisonous plants on livestock production. Westview Press, Boulder, Colo.

Olsen, J.D., G.D. Manners, and S.W. Pelletier. 1990. Poisonous properties of larkspur (Delphinium spp.). Collect. Bot. (Barcelona) 19:141-151.

Pelletier, S.W., N.W. Mody, K.I.Varughese, J.A. Maddry, and H.K. Desai. 1981. Structure revision of 37 lycoctonine-related alkaloids. J. Amer. Chem. Soc. 103:6536-6538.
Pfister, J.A. and D.R. Gardner. 1999. Consumption of low larkspur (Delphinium nuttallianum) by cattle. J. Range Manage. (in press).

Ralphs, M.H., G.D. Manners, J.A. Pfister, D.R. Gardner, and L.F. James. 1997. Toxic alkaloid concentration in tall larkspur species in the western U.S. J. Range Manage. 50:497-502.

SAS Institute Inc. 1989. SAS/STAT users guide. (Version 6). 4th ed. SAS Inst. Inc., Cary, N.C.

Wroe, B. and R. Smith. 1991. Poisonous plants on range and pasture. Agri-fax. Alberta Agr., Edmonton, AB. 3 p. 


\title{
Seasonal chemical composition of saltbush in semiarid grasslands of Jordan
}

\author{
MOH'D KHAIR J. EL-SHATNAWI, AND YASER M. MOHAWESH
}

Authors are assistant professor of Range Ecology, Natural Resources and the Environment Department, Faculty of Agriculture, Jordan University of Science and Technology, PO Box 3030, Irbid, Jordan, e-mail: mkhair@just.edu.jo, and agronomist, National Center for Agricultural Research and Technology Transfer, PO. Box 639, Baqa', Amman, Jordan.

\section{Abstract}

Saltbush (Atriplex halimus L.), a native shrub which is adapted to arid rangelands, was transplanted to the semiarid grassland at Jordan University of Science and Technology Campus in 1986. Our objective was to determine the seasonal changes in the chemical composition of the annual growth of leaves and stems of saltbush (Atriplex halimus L.) during 1995-96 and 1996-97. A strong positive correlation was found among $\mathrm{P}$, Ca, crude protein, and nitrogen free extract and a strong negative correlation was found between fiber and $P$, Ca, crude protein, and nitrogen free extract. Nitrogen free extract (NFE) had a strong positive linear correlation with $\mathrm{P}, \mathrm{Ca}$, and crude protein. $\mathrm{P}, \mathrm{Ca}, \mathrm{Ca}: \mathrm{P}$ ratio, crude protein, and NFE contents were found to be higher in leaves than in stems on all the occasions.

Leaves had relatively higher concentrations of $P, C a$, crude protein, and NFE during the growing season (February to April). Crude protein of leaves reached its maximum in March $(22.7 \%)$. The concentrations decreased, however, to $15 \%$ during the dry period (June to October). Crude protein content of stems ranged from 11.3 to $12.2 \%$. Fiber content of leaves was lowest during February and March (16.9 to 18\%), and reached maximum values during August and October. Saltbush is a good protein source for sheep during the dry season; however, $P$ content would not meet nutritional requirements of ewes.

Key Words: Atriplex halimus, crude protein, dry season, ewes, fiber, leaves, Middle East, stems

Atriplex spp. are halophytes that have considerable forage potential in the arid and semiarid rangelands of West Asia (Le Houerou 1992, 1995). In Jordan Atriplex spp. are thought to be a solution to feed shortages that occur during droughts and dormant seasons. Most forages usually have high nutritive value during early growth, but their nutritive value declines rapidly with maturity. Most shrubs generally have high levels of crude protein, phosphorous and calcium throughout the year (Stidham et al. 1982).

In Israel, Atriplex halimus L. furnishes protein, vitamins and minerals to sheep during summer and autumn (Benjamin et al. 1959). Sheep grazed on dormant crested wheatgrass ((Agropyron cristatum L.) had greater weight losses than those grazing a mix-

We express our gratitude to Dr. Kapur Ahlawat for improving the quality of this manuscript.

Manuscript accepted 28 Jun. 1999.
Resumen

En 1986 se transplantaron arbustos de "Saltbush" (Atriplex halimus L.) (una especie nativa adaptada a pastizales áridos) en un pastizal semiárido de la Universidad Científica y Tecnológica de Jordania. Nuestro objetivo fue determinar los cambios estacionales de la composición química del crecimiento anual de hojas y tallos de "Saltbush" (Atriplex halimus L.) durante las estaciones de crecimiento de 1995-1996 y 1996-1997. Se encontró una fuerte correlación positiva entre $\mathbf{P}$, Ca, proteína cruda, $y$ extracto libre de nitrógeno. También se encontró una fuerte correlación negativa entre la fibra y $P$, Ca, proteína cruda, y extracto libre de nitrógeno. El extracto libre de nitrógeno (ELN) tuvo una fuerte correlación lineal positiva con $P$, Ca y proteína cruda. En todos los muestreos el contenido de $\mathbf{P}, \mathrm{Ca}$, la relación $\mathrm{P}: \mathrm{Ca}$, proteína cruda, y ELN fueron mayores en hojas que en tallos.

Durante la estación de crecimiento (Febrero a Abril), las hojas tuvieron un contenido relativamente mayor de $P$, Ca, proteína cruda y ELN. La proteína cruda de las hojas alcanzó su máximo valor $(27 \%)$ en Marzo, sin embargo, la concentración disminuyó a $15 \%$ durante el período seco (Junio a Octubre). El contenido de proteína cruda de los tallos vario de 11.3 a $12.2 \%$. El menor contenido de fibra de las hojas ocurrió en Febrero y Marzo (16.9 a $18 \%$ ) y los valores máximos se alcanzaron en Agosto y Octubre. Durante la época seca, el "Saltbush" es una buena fuente de proteína para los ovinos; sin embargo, el contenido de $P$ podría no satisfacer los requerimientos nutricionales de las borregas.

ture of crested wheatgrass and fourwing saltbush (A. canescens (Pursh) Nutt.) (Otsyina et al. 1982). Protein content of A. cane sens leaves had decreased from $25 \%$ in April to $10 \%$ in August before it gradually increased during winter to about $20 \%$. The feed value of leaves again decreased during June through December (Thomson et al. 1997). Chatterton et al. (1971) reported a remarkable variation in the nutritive value of different parts of the plant A. polycarpa (Torr.) S. Wats. over the year.

Jordan has over 2.6 million sheep and 1 million goats, and the amount of supplemented feed stuff is estimated at 444 thousand tons (FAO 1994). Sheep in autumn depend on crop stubble and native pasture. Saltbush (A. halimus L.) is a native shrub found in many salty and arid regions of the Middle East including Jordan. It's a promising forage source and supplemental feed during dry seasons and emergencies, but the seasonal variation of its nutritive value and chemical composition has not been investigated. Our objective was to determine the seasonal changes in chemical 
composition of the current year's growth of leaves and stems of saltbush (Atriplex halimus L.) on semiarid grassland in Jordan.

\section{Materials and Methods}

\section{Site Description}

The saltbush on which this study was conducted grows on semiarid grassland located within the campus boundary of the Jordan University of Science and Technology (JUST) $22 \mathrm{~km}$ east of Irbid $\left(32^{\circ} 34^{\prime} \mathrm{N}, 36^{\circ} 0^{\prime} \mathrm{E}\right)$. Altitude is $520 \mathrm{~m}$, and the site is characterized by flat to gently rolling topography with less than $10 \%$ slope. The soil is a weakly cracked and deep silty clay. Natural vegetation is typical of Mediterranean semiarid grassland. Our study utilized 3 hectares of $A$. halimus L. transplanted in an adaptability trial during 1986-87 and protected from grazing. Mean annual precipitation for that site is $230 \mathrm{~mm}$, and annual rainfall during 1995-96 and 1996-97 occurred during October to April. Highest accumulations and the most rapid plant growth occurred during the period from January to March (Fig. 1). Plant growth usually starts during December and stops by the end of April due to dry-hot conditions.

\section{Sampling}

Four100-m transects were randomly selected. In 1995-96 and 1996-97, 16 saltbush shrubs on each transect were selected randomly, and 8 shrubs per tran-

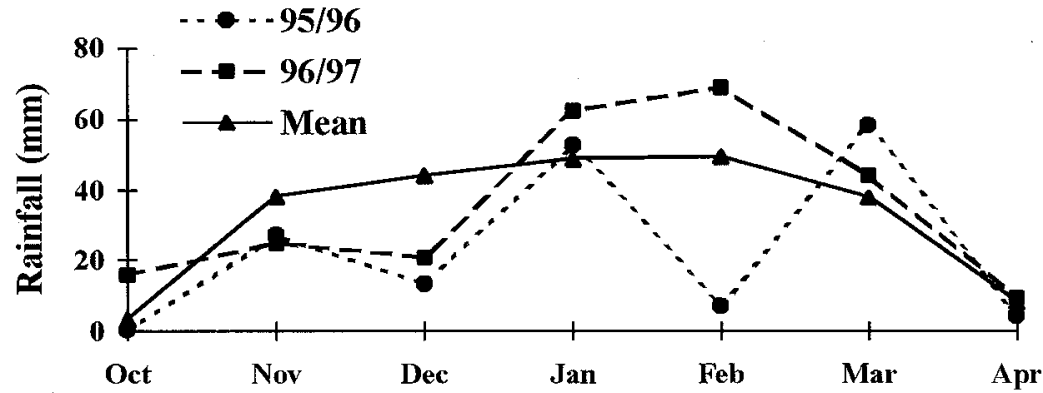

Fig. 1. Monthly rainfall $(\mathrm{mm})$ for $1995-96,1996-97$ and long term means $(\mathrm{n}=11)$.

\section{Chemical Analysis}

One hundred-gram samples of oven-dry leaves and stems from each shrub were milled to pass a $0.4-\mathrm{mm}$ screen and used for subsequent chemical analyses. Calcium was determined by atomic absorption spectrophotometer. Phosphorous was determined following Watanable and Olsen (1965) procedures. Crude protein (Nx6.25), nitrogen free extract (NFE) and fiber were determined according to AOAC (1984) procedures.

\section{Statistical Analysis}

The data were analyzed using a $2 \times 8 \times 2$ factorial using a randomized complete block design. Factors were years (2), months (8), and plant parts (2) with 4 replications. Null hypotheses related to all 3 main effects and the pertinent interactions were tested at the $\mathrm{P} \leq 0.01$ level of significance. Analyses of variance did not show a significant year effect (Table 1),

\section{Results}

Simple linear correlation analysis (Table 2) showed strong positive relationships between $\mathrm{P}, \mathrm{Ca}$, crude protein, and nitrogen free extract, whereas fiber exhibited a strong negative correlation with $\mathrm{P}, \mathrm{Ca}$, crude protein, and nitrogen free extract. Analyses of variance did not show a significant year effect, however, there were significant differences between leaves and stems and significant seasonal effects in the composition of leaves and stems during the year at $\mathrm{P} \leq 0.01$ (Table 1).

\section{Leaves}

Leaves of Atriplex halimus L. showed higher $(\mathrm{P} \leq 0.01) \mathrm{P}, \mathrm{Ca}, \mathrm{Ca}: \mathrm{P}$ ratio, crude protein, and nitrogen free extract (NFE) values than stems on any clipping date (Fig. 2). Leaves had maximum levels of $P$, $\mathrm{Ca}$, crude protein, and NFE during the February to April growing season, and the

Table 1. Significance levels in analyses of variance of various chemical components extracted from saltbush (Atriplex halimus L.) in Jordan from December 1995-October 1997.

\begin{tabular}{|c|c|c|c|c|c|c|c|c|}
\hline Source of variation & df & & $\mathrm{P}$ & $\mathrm{Ca}$ & $\mathrm{Ca}: \mathrm{P}$ & $\mathrm{CP}$ & NFE & Fiber \\
\hline replicate & $(\mathrm{r}-1)$ & 3 & ns & ns & $\mathrm{ns}$ & ns & ns & $\mathrm{ns}$ \\
\hline year & $(y-1)$ & 1 & ns & ns & ns & ns & ns & ns \\
\hline plant part & $(\mathrm{s}-1)$ & 1 & $* *$ & ** & ** & ** & ** & ** \\
\hline month & $(\mathrm{m}-1)$ & 7 & ** & ** & $* *$ & ** & $* *$ & ** \\
\hline year X month & $(y-1)(m-1)$ & 7 & $\mathrm{~ns}$ & $\mathrm{~ns}$ & $\mathrm{~ns}$ & $\mathrm{~ns}$ & ns & ns \\
\hline plant part X month & $(\mathrm{s}-1)(\mathrm{m}-1)$ & 7 & $* *$ & $* *$ & $* *$ & $* *$ & $* *$ & $* *$ \\
\hline year X plant part X month & $(\mathrm{y}-1)(\mathrm{s}-1)(\mathrm{m}-1)$ & 7 & $\mathrm{~ns}$ & $\mathrm{~ns}$ & ns & $\mathrm{ns}$ & $\mathrm{ns}$ & $\mathrm{ns}$ \\
\hline
\end{tabular}

** Significant at $\mathrm{P}<0.01$

ns Not significant

sect were utilized for the experiment each year. Samples were collected on 28 December, January, February, March, April, June, August, and October. On each sampling date, the current year's growth of 4 randomly selected shrubs was clipped, and the leaves and stems separated and dried at $70^{\circ} \mathrm{C}$ for 72 hours. therefore, means of the chemical composition of leaves and stems were pooled over years. Means were separated by Fisher's Least Significant Difference (LSD) at $\mathrm{P} \leq$ 0.01. Linear relationships among the chemical properties were determined by correlation techniques described by Steel and Torrie (1980).
$\mathrm{Ca}: \mathrm{P}$ ratio increased gradually from 5 during February to 11.7 during October (Fig. 2C). Crude protein content ranged from 15.8 to $22.7 \%$ (Fig. 3A), with the highest values detected in February $(20.8 \%)$ and March $(22.7 \%)$. Crude protein decreased to about $15 \%$ during the June to October dry period. Nitrogen free extract (NFE) 

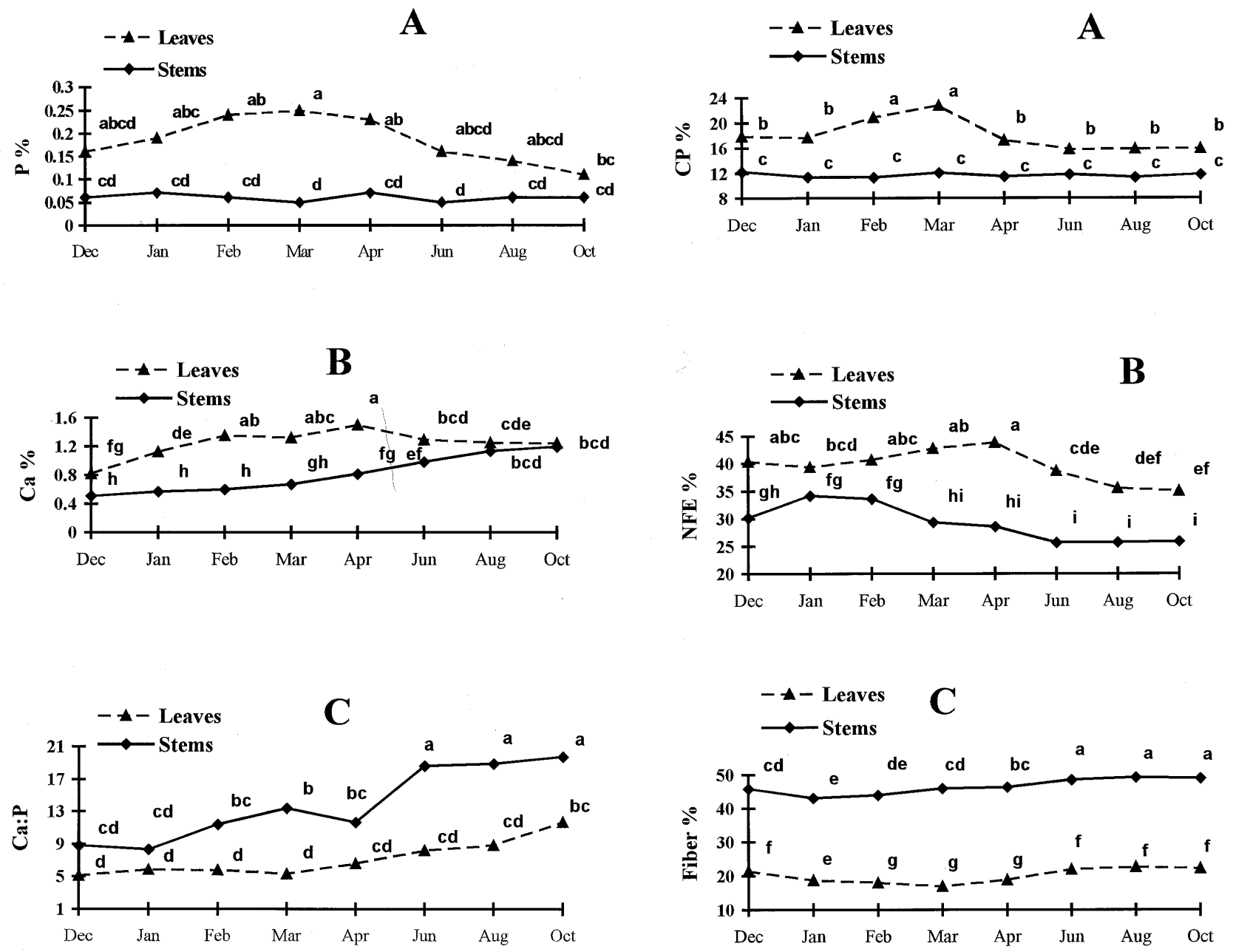

Fig. 2. Seasonal phosphorous (A), calcium $(B)$ and Ca:P ratio $(C)$ contents of saltbush $(A$. halimus $\mathrm{L}$.) leaves and stems during 1995-96 and 1996-97 at Jordan University of Science and Technology Campus. Means within a component having a common letter do not differ significantly $(P>0.01)$.

Fig. 3. Seasonal crude protein (A), nitrogen free extract $(B)$ and crude fiber $(C)$ contents of saltbush (A. halimus $\mathbf{L}$.) leaves and stems during 1995-96 and 1996-97 at Jordan University of Science and Technology Campus. Means within a component having a common letter do not differ significantly $(\mathbf{P}>0.01)$..

increased gradually from $40 \%$ at the December sampling date, to $44 \%$ during April. Thereafter NFE gradually decreased to $35 \%$ in October (Fig. 3B). Fiber content increased from a low in February $(16.9 \%)$ to a high of $22.6 \%$ in October (Fig. 3C).

\section{Stems}

Except for $\mathrm{P}$ and crude protein, where no seasonal changes occurred, the nutrient content of stems increased gradually from December to October (Fig. 2A and 3A). Crude protein content ranged from 11.3 to $12.2 \%$. Ca content was $0.5 \%$ during December, and it increased gradually to $1.22 \%$ in October (Fig. 2B). During October, $\mathrm{Ca}$ concentrations of leaves and stems were equal. The $\mathrm{Ca}: \mathrm{P}$ ratio increased gradually from 8.8 in December to 19.8 in October (Fig. 2C). Nitrogen free extract (NFE) was highest during January
(34.1\%) but started decreasing after February to a low of $25.8 \%$ in October (Fig. 3B). The crude fiber content of stems increased gradually from December (43\%) to October (49\%) (Fig. 3C).

\section{Discussion}

Jordanian rangeland has a unimodal precipitation pattern, with a short rainy period followed by an extended dry season furnishing limited opportunities for herbaceous forage production. Plant dormancy stimulates a decline in both quantity and quality of forage. Annual grasses may lose $75 \%$ of their protein content and up to $52 \%$ of their phosphorous during the dry season (Louis et al. 1983). Wheat and barley residue grazing starts immediatly after harvest in June and lasts until September. This provides the basic diet for sheep throughout the summer into autumn; when supplementary feeding begins (ACSAD 1983). The forage value of the crop residues deteriorates after a month of grazing, and the animals begin loosing weight. Supplementation with cotton seed meal or cereal grain at a rate of $100 \mathrm{~g} / \mathrm{day}^{-1}$ could stop weight losses (Turminini 1991).

Sheep usually need supplementation for 6 months in a normal year and 9 months during drought years (Nesheiwat and Muhammed 1987). The CP content of saltbush (Atriplex halimus L.) is high, and would be a good protein source for livestock during dry summer and autumn periods. Protein is one of the most limiting nutrients for range livestock production and its supplementation is cost effective, because it improves forage intake and 
Table 2. Correlation coefficients among some chemical components of A. halimus L. sampled in Jordan from December 1995-October 1997.

\begin{tabular}{llllll}
\hline \hline & $\mathrm{Ca}$ & $\mathrm{Ca}: \mathrm{P}$ & $\mathrm{CP}$ & $\mathrm{NFE}$ & Fiber \\
\hline $\mathrm{P}$ & $0.66^{* *}$ & $-0.72^{* *}$ & $0.92^{* *}$ & $0.93^{* *}$ & $-0.87^{* *}$ \\
$\mathrm{Ca}$ & & 0.04 & $0.89^{* *}$ & $0.50^{* *}$ & $-0.53^{* *}$ \\
$\mathrm{Ca}: \mathrm{P}$ & & & $-0.68^{* *}$ & $-0.77^{* *}$ & $0.79^{* *}$ \\
$\mathrm{CP}$ & & & & $0.90^{* *}$ & $-0.88^{* *}$ \\
$\mathrm{NFE}$ & & & & & $-0.85^{* *}$ \\
\hline
\end{tabular}

** Significant at $\mathrm{P}<0.01$

digestibility (Holechek and Herbel 1986). On Utah rangelands, Gade and Provenza (1986) compared the diet quality of sheep using crested wheatgrass and a wheatgrass-shrub mixture during winter. They found that sheep grazed on wheatgrassshrub mixtures had higher forage intake, higher crude protein intake, and lower fiber levels in their diets than sheep grazing a pure stand of wheatgrass. In our study, saltbush (A. halimus L.) crude protein and $\mathrm{Ca}$ contents were sufficient to meet ewes maintenance and lactation requirements during any time of the year. Phosphorus was deficient for ewes, suggesting supplements would be necessary to adjust the high $\mathrm{Ca}: \mathrm{P}$ ratio in their diet. Ewes require 7 to $9 \%$ crude protein for maintenance and 10 to $12 \%$ for lactation. They also need $0.15 \%$ to $0.20 \% \mathrm{P}$ for maintenance and 0.25 to $0.30 \%$ for lactation (Holechek et al. 1994). The introduction of saltbush (A. halimus L.) into semiarid grassland of Jordan would elevate the nutritive plain of livestock and possibly minimize the need for grain supplements during summer and autumn.

\section{Conclusion}

Semiarid grasslands usually supply livestock with high food quality during spring but forage quality declines rapidly as grass mature. Saltbush showed relatively high levels of protein and nitrogen free extract throughout the year. Saltbush is drought resistant and can be grazed during droughty years. Introducing saltbush into Jordan's grassland may improve the quality of the livestock diets and minimize grain supplementation during summer and autumn. Phosphorous supplementation, however, would be necessary to adjust the $\mathrm{Ca}: \mathrm{P}$ ratio.

\section{Literature Cited}

ACSAD. 1983. Studies of Houd-Al Hamad. Animal production in the Jordanian Hamad ACSAD-Damascus (in Arabic).
AOAC, Washington. 1984. Official Methods of Analysis of the Association of Official Analytical Chemists, Washington D.C.

Benjamin, R., Y. Orev, and E. Eyal. 1959. Grazing saltbush (Atriplex halimus) with cows and sheep. Rep. Agr. Res. Sta. Bet Dagan, Israel. no 266 (Hebrew, with English summary).

Chatterton, N.J., J.R. Goodin, and G.M. Mckell, et al. 1971. Monthly variation in the chemical composition of desert saltbush. J. Range Manage. 24:37-40.

FAO. 1994. Sheep production under extensive system a case study. Near East Regional Office, Food and Agr. Organ. of the United Nations.

Gade, A.E. and F.D. Provenza. 1986. Nutrition of sheep grazing crested wheatgrass versus crested wheatgrass-shrub pastures during winter. J. Range Manage. 39:527-530. Supplementing range livestock. Rangelands 8:29-33.

Holechek, J.L., R.D. Pieper, and C.H. Herbel. 1994. Range Management: Principle and Practices. Prentice Hall, Englewood Cliffs.

Le Houerou, H.N. 1992. Role of salt bushes (Atriplex spp.) in arid land rehabilitation in the Mediterranean basin: a review. Agroforestry Systems 18:107-148.

Le Houerou, H.N. 1995. Forage halophytes in the Mediterranean basin. pp 115-136.In: Chouker-Allah, R., C.V. Malcolm and A. Hamdy (eds.). Halophytes and biosaline Agriculture. MarcelDekker, Inc., New York, Basel, Hong Kong.

Louis, S.L., A. Dankintafo, B. Bookary, and N. Goumey. 1983. Seasonal influence on the nutritive value of the rangeland in Niger pastoral zone. Ministry of Rural Development US AID Tech. Bull. 2. Tahoua, Niger.

Nesheiwat, K. and J. Muhammed. 1987. Socio-economy and farming systems. Vol. 2 of the base-line study of Ma'in Pilot Project Perimeter. Amman-Jordan. MOA/FAO.

Otsyina, R., C.M. Mckell, and G. Van Epps. 1982. Use of shrubs to meet nutrient requirements of sheep grazing on crested wheatgrass during fall and early winter. J. Range Manage. 35:751-754.

Steel, R.G.D., and J.H. Torrie. 1980. Principles and Procedures of Statistics: A Biometrical Approach, 2nd ed. McGraw-Hill Co., New York, N.Y. systems in the Near East: Jordan pastoral

Holechek, J.L., and C.H. Herbel. 1986.
Stidham, N.D., J. Powell, F. Gary, and P.L. Claypool. 1982 Establishment, growth, utilization and chemical composition of introduced shrubs on Oklahoma Tallgrass Prairie. J. Range Manage. 35:301-304.

Thomson, E.F., S.N. Mirza, and S. Rafique et al. 1997. Utilization of fourwing saltbush for arid rangelands of highland Balochistan, Pakistan. In: N. Haddad, R. Tutwiler, and E. Thomson (ed), Improvement of crop-livestock integration systems in West Asia and North Africa. Savvy Press, Syria.

Turminini, A. 1991. By-products of crops and straw and formulation of rations. Range, feeds and animal production program. ICARDA, Aleppo.

Watanable, F.S. and S.R. Olsen. 1965. Test of an ascorbic acid method for determining phosphorous in water and $\mathrm{NaHCO}_{3}$ extract from soil. Proc. Soil Sci. Soc. 21:677-678. 


\title{
Grazing effects on spring ecosystem vegetation of California's hardwood rangelands
}

\author{
BARBARA ALLEN-DIAZ AND RANDALL D. JACKSON
}

Authors are associate professor and graduate student researcher, Department of Environmental Science, Policy, and Management-Ecosystem Sciences Division, 151 Hilgard Hall, University of California, Berkeley, Calif. 94720-3110 email: ballen@nature.berkeley.edu

Abstract

Three watersheds at the University of California's Sierra Foothill Research and Extension Center (SFREC), Marysville, Calif. were selected to study cattle grazing effects on the vegetation surrounding cold-water springs and their downslope creeks. Three spring-creek systems from each of 3 watersheds were randomly assigned to grazing treatments ( 9 total). Treatments were ungrazed, lightly grazed $\left(1,500 \mathrm{~kg}^{\circ} \mathrm{ha}^{-1}\right.$ residual dry matter), and moderately grazed $\left(1,000 \mathrm{~kg}^{\circ} \mathrm{ha}^{-1}\right.$ residual dry matter) based on degree of use in upland pastures encircling the spring-creek systems. Total herbaceous cover at springs varied significantly among the 6 years only once (greater in 1994 than all others) covarying with previous year's rainfall. Grazing intensity did not affect total herbaceous cover at springs. A year $X$ grazing treatment interaction $(P<0.05)$ was detected for total herbaceous cover at spring-fed creeks. Three years after grazing removal, total herbaceous cover on ungrazed creek plots surpassed cover at moderately grazed and lightly grazed plots. Moderately grazed plot herbaceous cover declined steadily throughout the first 3 years, while lightly grazed cover remained relatively stable. Plant community composition and stability by year and grazing treatment were analyzed with TWINSPAN. With few exceptions, stable plant communities persisted on sites regardless of grazing intensity or cover changes. Total herbaceous cover was sensitive to interannual fluctuations, especially under increased grazing intensities. This attribute renders cover a more useful gauge of ecosystem health than plant composition as the latter may not provide evidence of potentially deleterious grazing $X$ climate interactions until after soil erosion or water table characteristics are seriously, perhaps permanently, altered.

Key Words: Riparian, creek, cover, grazing, species composition

The ecology and management of California's annual grasslands, woodlands, and savannas have been well studied (Bartolome and Standiford 1992, Bartolome and McClaran 1992, Bartolome et al. 1994, Heady et al. 1992, Standiford et al. 1997). However, few studies examine cold-water spring ecosystems of these rangelands, or the potential for grazing effects on them (Allen-Diaz et al. 1998).

The authors thank James Bartolome and 2 anonymous reviewers for review and comments; Irene Timossi for information system management; Mark Spencer, Clay Taylor, Chris Campbell, Cheryl Lovato Niles, Jeff Fehmi and others for field sampling assistance; and Mike Connor and Sierra Foothill Research and Extension Center personnel for range management. The Integrated Hardwood Range Management Program, University of California funded this project.

Manuscript accepted 10 July 1999.

\section{Resumen}

Se seleccionaron tres cuencas hidrológicas de la Estación de Investigación y Extensión Sierra Foothills de la Universidad de California con el objetivo de estudiar los efectos del apacentamiento del ganado en la vegetación circundante de manantiales de agua fría y sus arroyos pendiente abajo. En cada cuenca, tres sistemas de manantial-arroyos se asignaron aleatoriamente a los tratamientos de apacentamiento ( 9 en total). Los tratamientos fueron; sin apacentamiento, apacentacentado ligeramente $(1,500$ $\mathrm{kg} \mathrm{ha}^{-1}$ de materia seca residual) y apacentacentado moderadamente $\left(1,000 \mathrm{~kg} \mathrm{ha}^{-1}\right.$ de materia seca residual), los tratamientos se basaron en el grado de utilización de tierras arriba que circundan los sistemas de manatial-arroyos. La cobertura total de la vegetación herbácea en los manantiales varió significativamente solo una vez en 6 años (en 1994 fue mayor que los otros años) y los cambios se correlacionaron con la precipitación del año anterior. La intensidad de apacentamiento no afecto la cobertura total de la vegetación herbácea de los manantiales. En la variable cobertura total de la vegetación herbácea de los manantiales-arroyo, se detecto una interacción año $x$ tratamiento de apacentamiento $(P<0.05)$. Después de 3 años de que el apacentamiento se suspendió, la cobertura total herbácea de las parcelas de los arroyos sin apacentar superó a la cobertura registrada en las parcelas con apacentamiento ligero y moderado. La cobertura de herbáceas de las parcelas con apacentamiento moderado disminuyo paulatinamente durante los primeros tres años, mientras que la cobertura de las parcelas con apacentamiento ligero permaneció relativamente estable. La composición y estabilidad de la comunidad vegetal por año y tratamiento de apacentamiento se analizaron con TWINSPAN. Con pocas excepciones, comunidades estables de plantas persistieron en los sitios, independientemente de la intensidad de apacentamiento o los cambios de cobertura. La cobertura total herbácea fue sensible a las fluctuaciones interanuales, especialmente bajo las mayores intensidades de apacentamiento. Este atributo, en comparación con la composición de la comunidad, representa una mejor medida de la salud del ecosistema que este ultima puede no proveer de evidencia del daño potencial de la interacción apacentamiento $x$ clíma hasta que la erosión del suelo o las características de agua freática son seriamente alteradas.

Managers assess range condition or health by comparing existing plant community composition to a standard (Dyksterhuis 1949, Busby et al. 1994). Plant species cover is the variable most often estimated for generating range condition classes. Although grazing management changes often effect changes in vegetation cover, Bartolome (1984) and Milchunas and Lauenroth (1993) 
suggested that species composition does not necessarily track cover variability and may lead to erroneous conclusions concerning long-term ecosystem productivity. Busby and Cox (1994) suggested that soil degradation and water quality parameters may be more important than plant species composition for assessing ecosystem health.

We tested the effects of different cattle grazing intensities on vegetation surrounding springs over 6 years on California's oak-dominated hardwood rangeland. We hypothesized that reduced grazing intensity would induce plant community composition change. However, we held no a priori notions regarding compositional change direction.

\section{Study Site}

Research was conducted at Sierra Foothill Research and Extension Center (SFREC). The study site was described in detail in Allen-Diaz et al. 1998. Briefly, SFREC has an average annual precipita-

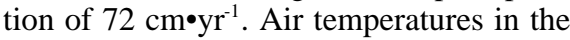
region range from monthly averages of $32.0^{\circ} \mathrm{C}$ in July to $2.2^{\circ} \mathrm{C}$ in January. Dominant vegetation is blue oak (Quercus douglasii Hook. \& Arn.)/gray pine (Pinus sabiniana Douglas) woodlands and savannas with introduced annual grass and forb understories. Soils in this area are classified as Auburn (loamy, oxidic, thermic, Ruptic-Lithic Xerochrepts) and Argonaut (fine, mixed, thermic Mollic Haploxeralfs) series (Herbert and Begg 1969).

As described previously, springs and their resultant creeks are quite small (about $0.5 \mathrm{~m}$ wide at the source). Wetland species (Table 1 for typical spring spp.) remain green in summer and sharply delineate a spring's boundaries, which extend an average of $3 \mathrm{~m}$ perpendicular to flow, forming oval-like borders. The highly palatable, perennial vegetation of spring ecosystems encourages intense cattle use. This is especially evident during summer months as upland annual grasses dry (Table 1 for typical annual grassland spp.). Concentrated utilization of springs creates visually striking vegetation impacts that motivated this study.

Three spring-creek systems were selected from each of 3 SFREC watersheds (Campbell, Schubert, and Forbes) for grazing treatment application (Allen-Diaz et al. 1998). Watersheds were selected for the presence of undeveloped springs, geographic proximity, and similar management histories. These watersheds had all been grazed by cattle at a moderate level
(800 to $1000 \mathrm{~kg} \bullet \mathrm{ha}^{-1}$ residual dry matter) since 1960 when the ranch came under University of California ownership. Prior to this ownership change, it is believed that greater livestock use levels existed (Kinney 1996), however, these use levels have not been quantified. Impediments to wildlife herbivory do not exist, nor do we believe any ever have in the past.

\section{Methods}

\section{Grazing treatment}

Each pasture within a watershed was randomly assigned a grazing treatment, ungrazed (UG), lightly grazed (LG), or moderately grazed (MG); applied from
1993 through 1997 . The approximately 2 ha pastures were grazed by cattle following autumn germination (usually November). Cattle were then removed for the winter and returned to pastures during the spring season annual vegetation rapidgrowth phase (February through April). Residual herbage on a dry matter basis (RDM) estimates were then made and cattle were returned to pastures in May to meet target RDM levels (Table 2 for annual RDM estimates). The number of animals placed in a pasture during any period was variable as it was based on available upland forage. Indeed, more animals were often placed on the lightly grazed plots because of site and interannual productivity differences (Allen-Diaz et al. 1998).

Table 1. Partial herbaceous-layer flora of springs and uplands.

\begin{tabular}{|c|c|c|}
\hline Species & Common name & Family \\
\hline \multicolumn{3}{|l|}{ Springs } \\
\hline Brachypodium distachyon L.. & False brome & Poaceae \\
\hline Briza minor $\mathrm{L}$ & Rattlesnake grass & Poaceae \\
\hline Carduus pycnocephalus L. & Italian thistle & Asteraceae \\
\hline Cynodon dactylon $\mathrm{L}$. & Crabgrass & Poaceae \\
\hline Cynosurus echinatus L. & Dogtail & Poaceae \\
\hline Cyperus niger Ruiz Lopez \& Pavon & Sedge & Cyperaceae \\
\hline Cyperus odoratus L. & Sedge & Cyperaceae \\
\hline Eleocharis macrostachya Britton. & $--^{1}$ & Cyperaceae \\
\hline Holcus lanatus L. & Velvet grass & Poaceae \\
\hline Lolium multiflorum Lam. & Italian ryegrass & Poaceae \\
\hline Mimulus guttatus DC. & Monkey flower & Scrophulariaceae \\
\hline Paspalum dilatatum Poiret & Dallis grass & Poaceae \\
\hline Polypogon monspeliensis L. & Annual beard grass & Poaceae \\
\hline Rorippa nasturtium-aquaticum Hayek & Water cress & Brassicaceae \\
\hline Rubus ursinus Cham. \& Schldl. & Blackberry & Rosaceae \\
\hline Stachys albens A. Gray. & Hedge nettle & Lamiaceae \\
\hline Stellaria media Villars & Common chickweed & Caryophyllaceae \\
\hline Typha angustifolia $\mathrm{L}$. & Cattail & Typhaceae \\
\hline Verbena bonariensis L. & $--^{1}$ & Verbenaceae \\
\hline Vitis californica Benth. & California grape & Vitaceae \\
\hline \multicolumn{3}{|l|}{ Uplands } \\
\hline Avena fatua $\mathrm{L} .$. & Wild oat & Poaceae \\
\hline Bromus diandrus Roth & Ripgut brome & Poaceae \\
\hline Bromus hordeaceus L. & Soft chess & Poaceae \\
\hline Bromus madritensis L. & Red brome & Poaceae \\
\hline Carduus pycnocephalus L. & Italian thistle & Asteraceae \\
\hline Centaurea solstitialis L. & Yellow star thistle & Asteraceae \\
\hline Elymus glaucus Buckley & Blue wildrye & Poaceae \\
\hline Erodium botrys Bertol. & Filaree & Geraniaceae \\
\hline Erodium cicutarium L'Her. ; & Filaree & Geraniaceae \\
\hline Galium aparine $\mathrm{L}$. & Common bedstraw & Rubiaceae \\
\hline Geranium molle L. & Geranium & Geraniaceae \\
\hline Hordeum murinum L. & Barley & Poaceae \\
\hline Lolium multiflorum Lam. & Italian ryegrass & Poaceae \\
\hline Medicago polymorpha L. & California burclover & Fabaceae \\
\hline Nassella pulchra Barkworth & Purple needlegrass & Poaceae \\
\hline Phalaris aquatica $\mathrm{L}$. & Harding grass & Poaceae \\
\hline Taeniatherum caput-medusae Nevski & Medusahead & Poaceae \\
\hline Torilis nodosa L. & Wild carrot & Apiaceae \\
\hline Trifolium hirtum All. & Rose clover & Fabaceae \\
\hline Vulpia myuros C. Gmelin & Annual festuca & Poaceae \\
\hline
\end{tabular}

No known common name 
Table 2. Annual residual dry matter (RDM) estimates made each June from 3 clipped plots in pastures surrounding spring sites to estimate grazing intensity.

\begin{tabular}{|c|c|c|c|c|c|c|c|c|}
\hline \multirow[b]{2}{*}{ Watershed } & \multirow[b]{2}{*}{ Treatment } & \multicolumn{5}{|c|}{ Grazing Year (September-June) } & \multirow[b]{2}{*}{ Mean } & \multirow[b]{2}{*}{ SE } \\
\hline & & $1992 / 3$ & $1993 / 4$ & $1994 / 5$ & $1995 / 6$ & $1996 / 7$ & & \\
\hline & & & & & $\left(\mathrm{kg} \bullet \mathrm{ha}^{-1}\right)$ & & & $\ldots$ \\
\hline \multirow[t]{3}{*}{ Campbell } & $\mathrm{UG}^{1}$ & 2586 & 1404 & 2347 & 1227 & 1478 & 1808 & 274 \\
\hline & $\mathrm{LG}^{2}$ & 1256 & 462 & 2240 & 1066 & 790 & 1163 & 301 \\
\hline & $\mathrm{MG}^{3}$ & 1248 & 798 & 1685 & 1040 & 742 & 1103 & 171 \\
\hline \multirow[t]{3}{*}{ Schubert } & UG & 6092 & 3031 & 5899 & $--^{4}$ & 1915 & 4234 & 1043 \\
\hline & LG & 1453 & 1413 & 3461 & 1592 & 878 & 1759 & 442 \\
\hline & MG & 1597 & 402 & 1013 & 1788 & 578 & 1076 & 272 \\
\hline \multirow[t]{3}{*}{ Forbes } & UG & 5019 & 2648 & 5317 & $--^{4}$ & 3114 & 4025 & 670 \\
\hline & LG & 5436 & 1807 & 5211 & 3403 & 3119 & 3795 & 680 \\
\hline & MG & 2509 & 1399 & 2224 & 1434 & 1660 & 1845 & 222 \\
\hline
\end{tabular}

Ungrazed

${ }^{2}$ Lightly grazed

${ }^{3}$ Moderately grazed

${ }^{4}$ Data not available

Cattle were English-cross yearlings, including Angus, Red Angus, and Hereford breeds that averaged $455 \mathrm{~kg}$ (Table 3). Actual use data for pastures surrounding springs were provided in AllenDiaz et al. (1998). Livestock were managed under a comprehensive SFREC health care program, which included immunization against locally common cattle diseases several times annually.

Livestock grazing during the growing season has little effect on forage composition or productivity on California's hardwood rangelands (Bartolome and McClaran 1992). Grazed California annual grass rangelands are managed so that target residual dry matter levels are achieved at the end of the annual grass growing season (late May) or before the new rains start (September) (Bartolome et al. 1980, Heady et al. 1992). Domestic grazing animals are generally allowed to graze rangeland pastures on a semi-continuous or periodic rotational basis so that at the end of the growing season RDM target levels for the grassland are met. Animal management objectives include maintaining or enhancing body weight, and animal numbers are adjusted depending on the quality and quantity of forage available at any time during the annual grass growth cycle. Other elements of the rangeland landscape, such as springs, are not managed for per se. Rather, these ecosystems experience cattle use levels in proportion to their desirability as green forage and place of water.

Experienced Research Center annual grassland range managers monitored grazing treatment intensity during each treatment period. Cattle were left on a site until a visually estimated residual dry matter (RDM) target level was attained during any grazing period. To quantify grazing treatment levels, upland RDM was mea-

\section{Statistical analyses}

Potential differences in total herbaceous cover at springs and creeks among grazing treatments were assessed with split-plot, repeated measures ANOVA (S-PLUS 1993). Three watersheds comprised a blocking variable that effectively reduced error variance by partitioning site-to-site variability out of the ANOVA model. Each watershed was subjected to 3 grazing treatment levels (whole plot) repeatedly measured over 6 years (and 6 weeks for 1997; split plot). Homoscedasticity was verified for both factors but significant covariance among years indicated nonindependence across factor levels rendering univariate analyses inappropriate for significance tests of temporal variation (Winer 1971). Hence, MANOVA was performed on year-wise orthogonal contrasts of total cover for tests of time. Orthogonal contrasts were created by multiplying total cover by a coefficient matrix whose determinant equaled zero. MANOVA was then performed using yearly responses as dependent variables (Venables and Ripley 1997). When significant main or interaction effects were detected, pooled standard errors of the differences among means were examined to ascertain which treatment levels gave rise to significant differences main or interaction effects.

Temporal changes in plant species composition across grazing treatments were assessed with TWINSPAN, a divisive, polythetic classification program (Hill 1979). Default cut-levels were used to classify each pasture-year combination.

\section{Results}

Vegetative "hits" were determined according to the first foliar intercept in the herbaceous layer. Total herbaceous cover was calculated as total hits minus non-vegetation hits divided by total hits. Plant species identification and nomenclature followed The Jepson Manual (Hickman 1993). ceous cover at springs. Interannual variation was significant only in 1994, when total herbaceous cover was greater than cover totals in 1995 and $1997(\mathrm{P}<0.05)$.

Table 3. Cattle abundance and mean weight in each grazing period for 3 treatments. (Actual use dates and number of animals per treatment can be found in Allen-Diaz et al. 1998).

\begin{tabular}{lcc}
\hline \hline Grazing treatment period & Animal type & Animal weight \\
\hline & & $(\mathrm{kg})$ \\
November-December 1992 & cow & $360-405$ \\
March-May 1993 & cow & $360-405$ \\
November-December 1993 & cow & $360-405$ \\
March-May 1994 & cow & 455 \\
May 1994* & steer & 225 \\
December 1994-May 1995 & cow & 455 \\
February 1996-May 1996 & cow, calf & 455,214 \\
November 1996-May 1997** & cow, calf, bull & $455,214,475$ \\
\hline
\end{tabular}

*adjustment to reach RDM standards

**7 bulls for 2 days on Campbell LG 


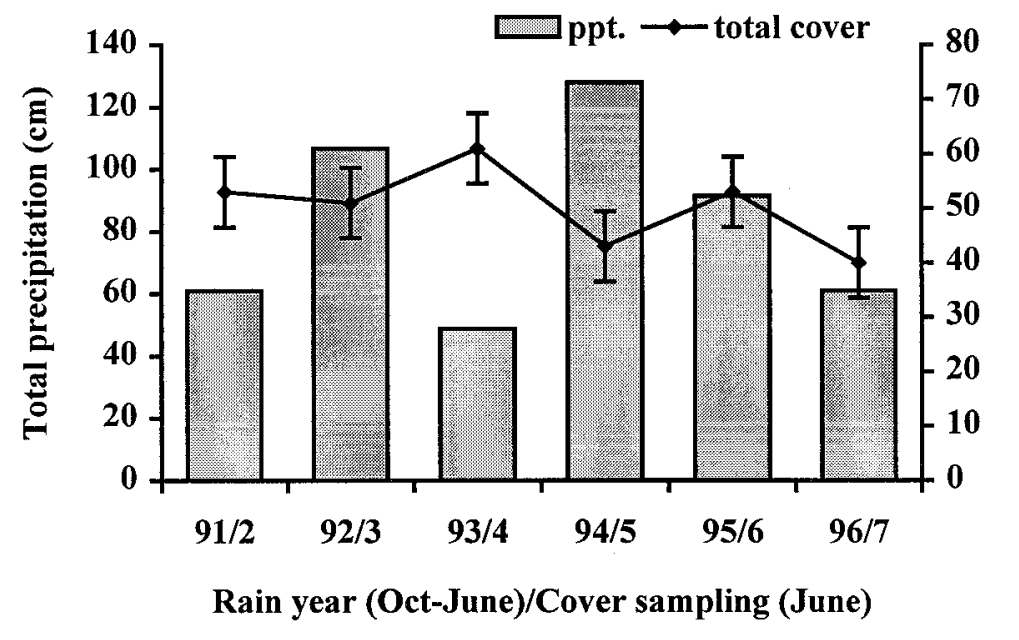

Fig. 1. Annual precipitation and total herbaceous cover at springs.

Precipitation well above average in the 1992/93 rain-year coupled with below average precipitation for the 1993/94 rain year probably contributed to increased cover in 1994 and reduced cover in 1995 (Fig. 1).

A significant grazing $\mathrm{X}$ year interaction was determined for total herbaceous cover at creek sites $(\mathrm{P}<0.05)$. Grazing treatment groups did not differ significantly for 1992 and 1993 (Fig. 2). But, in 1994, ungrazed (UG) cover increased dramatically from $63 \%$ to $86 \%$ while the moderately grazed (MG) group declined from $74 \%$ to $59 \%$ total herbaceous cover. The UG group retained greater cover than $\mathrm{MG}$ and lightly grazed (LG) in 1995 and 1996, but not in 1997. The LG group maintained the most stable total herbaceous cover val- ues over the study period ranging between $45-55 \%$. The MG group cover ranged from $80 \%$ at the beginning of the study (1992) to $34 \%$ one year after the lowest rainfall year (1994).

TWINSPAN classification analysis showed that only one spring transitioned to a new community type, a result of Rubus spp. expansion at the Forbes moderately grazed (MG) spring plot (Fig. 3). The transition occurred between 1992 and 1993 and has an associated eigenvalue $(\lambda)$ of 0.434 indicating a high goodness-ofsplit (Jongman et al. 1995). All other splits were based on dominant tree presence (Salix spp., $\lambda=0.556)$, Typha angustifolia L. presence $(\lambda=0.474)$, and Rhamnus cal ifornica Eschsch. presence $(\lambda=0.359)$, which changed little during the study.

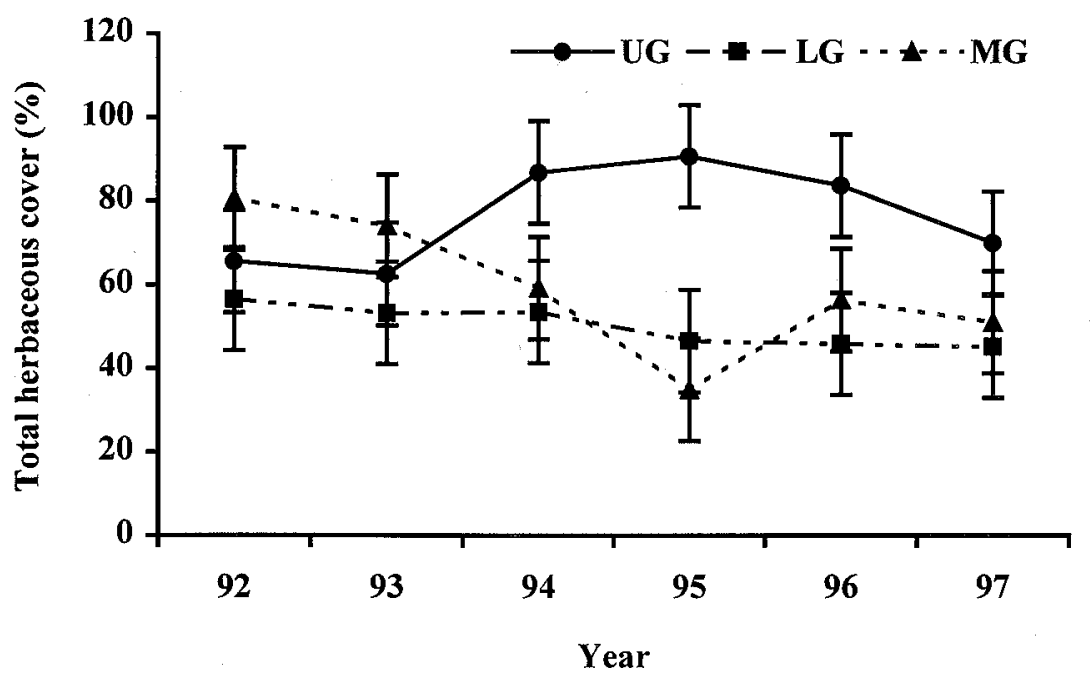

Fig. 2. Total herbaceous cover by grazing treatment at creeks.

Results based on 1997 quasi-weekly sampling showed no grazing treatment effects and no temporal variation in total herbaceous cover at springs. A year $\mathrm{X}$ grazing interaction for total herbaceous cover at creeks $(\mathrm{P}<0.01)$ reflected a difference between LG and MG for the initial 1997 sampling week (11 April). Lightly grazed and $\mathrm{MG}$ groups then stabilized at $\sim 50 \%$ herbaceous cover for the remainder of the 1997 6-week sampling period. The TWINSPAN results showed no compositional changes over the 6-week sampling period.

\section{Discussion}

Domestic livestock have grazed the Sierra Foothill Research \& Extension Center (SFREC) area for about 120 years. Although grazing intensity has certainly varied during this period, springs and their resulting creeks likely experienced periods of intense utilization, especially during summer. With the introduction of SFREC range management (1960), use at springs remained concentrated but less continuous, allowing for vegetative recovery and regrowth of perennial vegetation during rest periods. At SFREC, cattle are moved often, usually dictated by research needs.

While mean residual dry matter (RDM) target levels were met for the 6-year period, moderate- and light-grazed targets were transposed in several years (Table 2). This resulted from difficulties in reconciling visual upland RDM estimates with visual observations of spring use and because the presence of particular species at certain sites (Typha angustifolia L., Rhamnus californica Eschsch.) somewhat physically deterred riparian use until surrounding annual grasses had been heavily utilized. Moderately grazed and lightly grazed (LG) targets were also occasionally transposed because of upland vegetation regrowth under more favorable weather conditions after animals had been removed. Hence, cattle were sometimes removed from pastures before upland RDM targets were met. We do not believe that the minor interannual differences in RDM target levels affected the overall 6year results.

In fact, our study continued the 120-year history of periodic, intense use of the spring systems at both LG and moderately grazed (MG) treatment levels, but especially at MG levels. The ungrazed (UG) treatment can be thought of as release from 120 years of MG use. Grazing treatments, including complete protection, did 


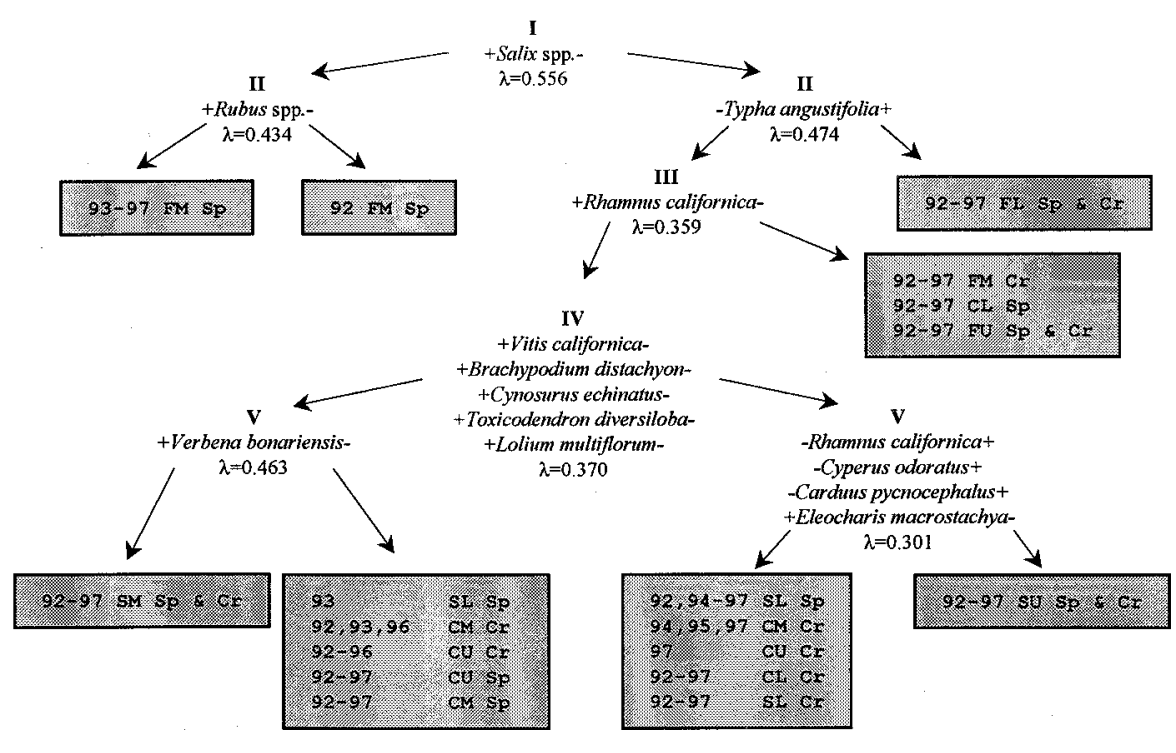

Fig. 3. TWINSPAN classification results. Roman numerals indicate different division levels. Numbers in shaded boxes indicate year, first letter denotes watershed $(F=F o r b e s$, $\mathbf{S}=$ Schubert, $\mathbf{C}=$ Campbell $)$, second letter denotes grazing treatment $(\mathrm{M}=$ moderately grazed, L=lightly grazed, U=ungrazed), "Sp" denotes spring-site, "Cr" denotes creek-site. Classification divisions were based on presence (+) or absence (-) of noted species. Strength of a given division is measured by eigenvalue $(\lambda ; 0.00-1.00$ range $)$.

not alter total herbaceous cover at springs or species composition at springs or creeks during the 6-year study.

The finding that MG plots changed in total cover more among years at creeks and springs than either the LG or UG groups, possibly under the influence of rainfall fluctuations, is compelling. Annual rainfall patterns control variations in species dominance on California's annual grasslands (Pitt and Heady 1978). It appears that these same patterns could similarly influence herbaceous cover in the perennial vegetation of low-flow spring systems, but with a 1-year time lag (Fig. 1). We did not observe interannual rainfall induced shifts in vegetation composition, an anticipated result, because seed bank, edaphic characteristics, and water, which are known to affect annual uplands, are less limiting at spring ecosystems.

We speculate that prolonged drought in moderately grazed situations probably reduces herbaceous cover at both springs and creeks, but without an immediate impact on plant community composition until some low-cover threshold is crossed (sensu Bartolome 1984). We hypothesize that soil loss and decreasing water table depth would eventually produce compositional changes on moderately grazed systems, given drought conditions. As spring flows seasonally waned, the changing pattern of water table drawdown shown to affect composition in wet meadows (Allen-Diaz 1991) should eventually induce compositional transitions. Shallowrooted annual species would move into formerly saturated areas. It is unknown whether these changes would be fluid enough that a return to pre-drought springflow would result in a linear, reverse transition to pre-drought species composition and spatial extent. However, given that this system has been moderately grazed for $120+$ years, enduring several droughts, it seems apparent that the plant communities found presently represent some relatively stable result of Mediterranean-type climatic regimes. Monitoring to detect threshold response of these spring-creek systems under continued grazing exclusion and increased grazing intensity (target $\sim 600 \mathrm{~kg} \mathrm{ha}^{-1} \mathrm{RDM}$ ) will continue.

Instead of showing more sensitivity to grazing, ample water supply seems to buffer deleterious grazing effects at springs and spring-fed creeks. This buffering apparently stabilizes perennial spring vegetation composition. We conclude that species composition is not sensitive to existing grazing systems that include periodic intense use coupled with overall moderate grazing levels on uplands. Instead, spring vegetation composition appears resistant to changes in both grazing and climatic conditions.

However, total vegetative cover appears to be a more useful metric for abiotic and biotic resource conservation in these systems. We base this conclusion on our finding that total herbaceous cover is sensitive to weather variability, especially under higher grazing intensities. Because total cover is directly linked to erosion rates and hydrologic processes (Busby et al. 1994, Busby and Cox 1994), total cover may prove to be an appropriate monitoring parameter for these systems.

\section{Literature Cited}

Allen-Diaz, B. H. 1991. Water table and plant species relationships in Sierra Nevada meadows. Amer. Midland. Natur. 126:30-43.

Allen-Diaz, B. H., R. D. Jackson, and J. Fehmi. 1998. Detecting channel morphology change in California's hardwood rangeland spring ecosystems. J. Range Manage. 51:514-518.

Bartolome, J. W. 1984. Impacts of grazing intensity and grazing systems on vegetation composition and production, $\mathrm{p}$. 917-925 In: Committee on Developing Strategies for Rangeland Management (ed.), Developing strategies for rangeland management: a report. Westview Press, Boulder, Colo.

Bartolome, J. W. and M. P. McClaran. 1992. Composition and production of California oak savanna seasonally grazed by sheep. J. Range Manage. 45:103-107.

Bartolome, J. W. and R. B. Standiford. 1992. Ecology and management of Californian oak woodlands. p. 115-118. In: Peter F. Ffolliott, et al. (eds.), Ecology and management of oak and associated woodlands: perspectives in the southwestern United States and northern Mexico, USDA Forest Serv. GTR RM-218, Sierra Vista, Ariz.

Bartolome, J. W., B. H. Allen-Diaz, and W. D. Tietje. 1994. The effect of Quercus douglasii removal on understory yield and composition. J. Range Manage. 47:151154.

Bartolome, J. W., M. C. Stroud and H. F. Heady. 1980. Influence of natural mulch on forage production on differing California annual range sites. J. Range Manage. 33:4-8.

Busby, F. E. and C. A. Cox. 1994. Rangeland health: new methods to classify, inventory, and monitor rangelands. Renewable Resources J. 12:13-19.

Busby, F. E., J. C. Buckhouse, D. C. Clanton, G. C. Coggins, G. R. Evans, K. L. Gadzia, C. M. Jarecki, L. A. Joyce, D. Loper, D. L. Merkel, G. B. Ruyle, J. W. Thomas, J. H. Wald, and S. E. Williams. 1994. Rangeland health: new methods to classify, inventory, and monitor rangelands. Com. on Rangeland Classification, Board on Agr., Nat. Res. Council. Nat. Academy Press, Washington, D.C.

Dyksterhuis, E. 1949. Condition and management of rangeland based on quantita- 
tive ecology. J. Range Manage. 2:104-115.

Heady, H. F., R. P. Gibbens, and R. W. Powell. 1959. A comparison of the charting, line intercept, and line point methods of sampling shrub types of vegetation. J. Range Manage. 12:180-188.

Heady, H. F., J. W. Bartolome, M. D. Pitt, G. D. Savelle, and M. C. Stroud. 1992. California prairie, p. 313-332 In: R.T. Coupland (ed.), Natural grasslands. Vol. 8A Elsevier, New York, N.Y.

Herbert, F. W. and E. L. Begg. 1969. Soils of the Yuba Area, California. County of Yuba, Calif., Davis, Calif.

Hickman, J. C. 1993. The Jepson Manual. University of California Press, Berkeley, Calif.
Hill, M. O. 1979. TWINSPAN-a FORTRAN program for arranging multivariate data in an ordered two-way table by classification of the individuals and attributes. Cornell University, Ithaca, N.Y.

Jongman, R. H., C. J. F. ter Braak, and O. F. R. Van Tongeren. 1995. Data analysis in community and landscape ecology. Cambridge University Press, Cambridge.

Kinney, W. C. 1996. Conditions of rangelands before 1905 , p. 31-46 In: Univ. of Calif. Centers for Water and Wildland Resources (ed.), Sierra Nevada Ecosystem Project, Final Rept. to Congress. Vol. II, Davis, Calif.

Milchunas, D. G. and W. K. Lauenroth. 1993. Quantitative effects of grazing on vegetation and soils over a global range of environments. Ecol. Monogr. 63:327-366.
Pitt, M. D. and H. F. Heady. 1978. Responses of annual vegetation to temperature and rainfall patterns in northern California. Ecol. 59:336-350.

S-PLUS. 1993. Statistical Sciences, S-PLUS Programmer's Manual, Version 3.2. StatSci, a division of MathSoft, Inc., Seattle, Wash.

Standiford, R., N. McDougald, W. Frost, and R. Phillips. 1997. Factors influencing the probability of oak regeneration on southern Sierra Nevada woodlands in California. Madroño 44:170-183.

Venables, W. N. and B. D. Ripley. 1997. Modern applied statistics with S-PLUS. Springer, New York, N.Y.

Winer, B. J. 1971. Statistical principles in experimental design. McGraw-Hill, New York, N.Y. 


\title{
Switchgrass growth and development: Water, nitrogen, and plant density effects
}

\author{
M. A. SANDERSON AND R. L. REED
}

Authors are research agronomist, USDA-ARS Pasture Systems and Watershed Management Research Laboratory, Curtin Road, University Park, Penn. 16802-3702 and forage specialist, The Samuel Roberts Noble Foundation, Box 2180, Ardmore, Okla. 73402. At the time of the research the authors were associate professor and research associate, Texas A\&M University Agricultural Research and Extension Center, Stephenville, Tex.

\begin{abstract}
Switchgrass (Panicum virgatum L.), an important component of the tallgrass prairie, is a productive warm-season forage grass. Interest in growing switchgrass for alternative uses has raised questions about resource use during production. The objective of our study was to examine how resource inputs affected interspecific plant competition in switchgrass. 'Alamo' switchgrass was established from seed in outdoor lysimeters in May 1993 and grown under 22 or $112 \mathrm{~kg} \mathrm{~N} \mathrm{ha}^{-1}$, and under field capacity or water-deficit conditions until August 1994. Plant spacing varied systematically from 10 to $70 \mathrm{~cm}$. Plants were harvested in late summer each year and individual plant dry weight, tiller number, leaf area, and morphological development stage were measured. Soil moisture tensions below $\mathbf{- 4 5} \mathrm{kPa}$ reduced switchgrass photosynthetic rates and xylem pressure potential. As plant spacing increased, tiller number, leaf area, plant dry weight, and morphological development stage increased. Plant dry weight and tiller number in the establishment year was not affected by $\mathrm{N}$ input. Established plants in 1994, however, responded to high $\mathrm{N}$ input at low plant densities with 50 to $100 \%$ greater leaf area and up to 3-fold greater plant dry weight compared to the low-N treatment. The increased plant dry weight at high $N$ input resulted from increased individual tiller weight and not increased tiller number. Our data indicate that competitive responses of switchgrass plants at high plant densities were controlled by competition for aboveground resources, as plant yield and morphology at high densities were not affected by water or $\mathrm{N}$ inputs.
\end{abstract}

Key Words: Panicum virgatum, morphological development, stress

Switchgrass is a warm-season perennial grass commonly grown in the Great Plains for harvested forage and grazing. Recent interest in alternative uses for switchgrass (e.g., biomass energy feedstock; McLaughlin and Walsh 1998) has prompted questions about how resource inputs (such as water and nutrients) affect growth, development, and plant relations of switchgrass. Water

Research supported by the Biofuels Systems Division under contract DECo5-840R21400 to Oak Ridge National Laboratory managed by Lockheed Martin Energy Systems. The authors thank Dr. Stan Wullschleger, Oak Ridge National Laboratory, for advice in conducting this experiment and for the use of the time domain reflectometer.

Manuscript accepted 16 May 1999.

\section{Resumen}

"Switchgrass" (Panicum virgatum L.), un componente importante de las praderas de zacares altos, es un zacate forrajero productivo de estación caliente. El interés de cultivar "Switchgrass" para usos alternativos ha generado preguntas acerca del uso de recursos durante la producción. El objetivo de nuestro estudio fue examinar como la adición de recursos afectó la competencia interespecífica del "Switchgrass". En Mayo de 1993, mediante semilla, se estableció el zacate "Switchgrass" variedad 'Alamo' en lísimetros colocados en el exterior, las plantas se fertilizaron con 22 o $112 \mathrm{~kg} \mathrm{ha}^{-1}$ de nitrógeno y crecieron bajo condiciones de capacidad de campo o déficit de humedad hasta Agosto de 1994. El espaciamiento entre plantas vario sistemáticamente de 10 a $70 \mathrm{~cm}$. Las plantas se cosecharon a fines del verano de cada año y a cada una de ellas se les determino individualmente el peso seco, número de hijuelos, área foliar y desarrollo morfológico. Tensiones de humedad del suelo abajo de a $-45 \mathrm{kPa}$ redujeron las tasas fotosintéticas y el potencial de presión del xilema del "Switchgrass". Conforme el espaciamiento entre plantas aumento, el número de hijuelos, área foliar, peso seco y desarrollo morfológico también aumentaron. Durante el año de establecimiento, la adición de nitrógeno no afecto el peso seco ni número de hijuelos de las plantas. Sin embargo, en 1994, las plantas establecidas a respondieron a la adición alta de nitrógeno; a densidades bajas de plantas, el área foliar aumento de 50 a $100 \%$ y el peso seco por planta hasta en 3 veces comparadas con las plantas con una adición baja de nitrógeno. El aumento del peso seco de las plantas en el tratamiento alto en nitrógeno fue producto de un aumento del peso individual de los hijuelos y no de un incremento en el número de ellos. Nuestros datos indican que la respuesta competitiva de plantas de "Switchgrass" en altas densidades fue controlada por la competencia por los recursos arriba de la superficie del suelo ya que el rendimiento por planta y su morfología a altas densidades no fueron afectados por la adición de nitrógeno o agua.

and nitrogen are the principal resources limiting productivity in perennial warm-season grass ecosystems (Epstein et al. 1996) and efficient use of these inputs in switchgrass production is critical.

Competition between plants is affected by plant population density (nearness and number of neighbors) and resource availability (Murphy and Briske 1992). In grasses, several morphogenetic changes, such as reduced tillering and increased shoot 
height, are presumably mechanisms for individual plants to adapt to resource availability (Ballare et al. 1995). These changes may buffer fluctuations in herbage yield. For example, Sanderson et al. (1996) reported that herbage yield of switchgrass was the same whether grown in rows spaced 10 or $100 \mathrm{~cm}$ apart because of compensatory responses in tiller number and size. At low plant population densities, individual plants may exploit larger pools of resources from above and below ground. If some soil resources are limited, input of additional water or nutrients should compensate for increased plant density.

The objective of our study was to examine how $\mathrm{N}$ and water affected competition among plants in switchgrass. We varied plant density, $\mathrm{N}$ fertility, and water availability and measured tillers and leaf area per plant, individual plant dry weight, and developmental stage to examine effects of these treatments on switchgrass morphology and development.

\section{Materials and Methods}

'Alamo' switchgrass seed was planted in sixteen, $1.8-\mathrm{m}$ diameter by $0.6-\mathrm{m}$ deep lysimeters (galvanized metal tanks) on 4 May 1993 at the Texas A\&M University Agricultural Research and Extension Center at Stephenville, Tex. The lysimeters were outdoors in 2 rows spaced $2 \mathrm{~m}$ apart. The soil in each lysimeter was a Bunyan loam (fine loamy, mixed, nonacid, thermic, Typic Udifluvents). The lysimeters were filled so that the original soil profile and bulk density were maintained as much as possible. A $10-\mathrm{cm}$ layer of pea gravel was placed in the bottom of each lysimeter and a 5-cm outlet was maintained for water drainage. The lysimeters were filled with soil in 1992 and allowed to settle until 1993. Analysis of soil samples taken to $15 \mathrm{~cm}$ in 1993 indicated 3.3 $\mathrm{mg} \mathrm{NO}_{3}-\mathrm{N} \mathrm{kg} \mathrm{kg}^{-1}$ of dry soil, $22 \mathrm{mg}$ extractable $\mathrm{P} \mathrm{kg}^{-1}, 108 \mathrm{mg}$ extractable K $\mathrm{kg}^{-1}$ and a $\mathrm{pH}$ of 8.0.

The planting arrangement in each lysimeter was a systematic design for plant spacing experiments (Nelder 1962). Plots were arranged in a wagon-wheel lay out with 8 radii (spokes) and 4 plants per radius. Each radius was planted along its entire length with switchgrass seeds. Plants were thinned on 8 June 1993 to 1 plant each at 10,20,40, and $70 \mathrm{~cm}$ from the center of the lysimeter. Plants were watered in all lysimeters to ensure establishment.
Treatments applied to the lysimeters included $\mathrm{N}$ fertilizer rates at 22 or $112 \mathrm{~kg}$ $\mathrm{N} \mathrm{ha}^{-1}$ (as ammonium nitrate, no other fertilizer was applied) and soil water levels of approximately field capacity and $50 \%$ water deficit. The $\mathrm{N}$ fertilizer was applied in July of 1993 after seedlings had established (tillers had formed on the main stem), and in April of 1994. Beginning 7 July 1993, the water levels were imposed and maintained by an automated watering system controlled by tensiometers (Soil Moisture Equipment model 2725, Santa Barbara, Calif.) placed $30 \mathrm{~cm}$ deep in each lysimeter. The tensiometers had a magnetic switch that triggered a solenoid valve when soil water tension fell below a preset level of $-10 \mathrm{kPa}$ for the field capacity treatment and $-50 \mathrm{kPa}$ for the water deficit treatment. A timing device was programmed to query the solenoid valves at 0800,1200 , and 1700 hours each day. If the solenoid was switched on, water was applied for 1 hour. Water was distributed within the lysimeter via a drip irrigation system with 9 emitters spaced $10 \mathrm{~cm}$ apart and arranged in a circle. The experimental design was a randomized complete block with a 2 x 2 factorial arrangement of $\mathrm{N}$ and water levels in 4 blocks.

Photosynthetic rates were measured periodically to determine if treatments affected plant physiological functions. Photosynthetic rate of the most recent fully expanded leaf blade on 2 tillers from 2 plants at the $40-\mathrm{cm}$ spacing in each lysimeter was measured on 7 dates in 1993 and 6 dates in 1994 with a Li-Cor 6200 portable photosynthesis system (Li-Cor Inc., Lincoln, Neb.). Preliminary measurements showed that plant density did not affect photosynthetic rates. Measurements were made during 1000 to 1400 hours on clear days. Only leaves in the fully exposed upper portion of the plant were measured. Leaves used for photosynthesis measurements were also used for xylem pressure potential measurements immediately after with a leaf pressure chamber (Scholander et al. 1965). In 1994, volumetric soil water content to a $30-\mathrm{cm}$ depth was estimated with a calibrated time domain reflectometer (Trase System I, Soil Moisture Equipment Co., Santa Barabara, Calif.) on the days when photosynthesis measurements were made.

Plant height, tiller number per plant, and stage of morphological development (Sanderson, 1992) were measured weekly on each plant at each density on 4 radii beginning 28 June 1993 and 18 April 1994 and continuing until 1 September 1993 and 15 August 1994. On 9 September
1993 and 20 August 1994, plants in 4 radii from each lysimeter were harvested by hand to a $15-\mathrm{cm}$ stubble. Tiller number per plant, morphological development stage of 5 tillers per plant, height of the 2 tallest tillers, and leaf blade area and dry weight ( 2 radii only) of each plant were measured. Plant and leaf blade dry weight were determined by drying at $55^{\circ} \mathrm{C}$ for 48 hours. Total Kjeldahl $\mathrm{N}$ was determined on leaf blades of plants in 1 radius from each lysimeter in 1993 and 1994. In August 1994, root mass was determined in each lysimeter by taking five, $7.5-\mathrm{cm}$ diameter by $60-\mathrm{cm}$ deep soil cores and washing roots from the soil over a $0.5 \mathrm{~mm}$ sieve. Roots were dried at $55^{\circ} \mathrm{C}$ for 72 hours to determine dry weight. In 1994, the plant crowns (stubble and plant material to a $5-\mathrm{cm}$ depth) were dug from the soil and the total number of visible buds (crown and rhizome buds) were counted.

The data were analyzed as a 2 × 2 factorial with 4 replicates. Responses to plant spacing were determined by linear regression and a comparison of regression slopes and intercepts of each treatment (SAS 1988).

\section{Results and Discussion}

\section{Soil Water Levels in Lysimeters and Plant Physiological Function}

During 1993, soil water tension was relatively constant in lysimeters used for the field capacity treatment (Fig. 1). The water-deficit treatment developed soil water deficits during 15 July to 13 August, 19 to 23 August, and 27 August to 1 September. In each instance (except for 12 August) the water deficit was relieved by natural rainfall. All lysimeters were rewatered to field capacity on 12 August to start a second wet-dry cycle.

During 1994, there were 4 periods of low soil water in the water-deficit treatment: 20 May to 6 June; 21 June to 1 July; 11 to 23 July; and 26 July to 8 August (Fig. 1). The high-N, water-deficit treatment developed a lower soil water tension in the upper $30 \mathrm{~cm}$ of soil than did the low-N field-capacity treatment probably because there was a greater amount of transpiring biomass in the high $\mathrm{N}$ treatment. Despite irrigation, the field-capacity treatment developed relatively low soil moisture tensions during 27 May to 1 June, 1 July to 5 July, and 6 July to 11 July. Measurements of volumetric soil water content at 5 dates in 1994 confirmed the soil water tensions measured by tensiometer (Table 1). Rainfall was much less 


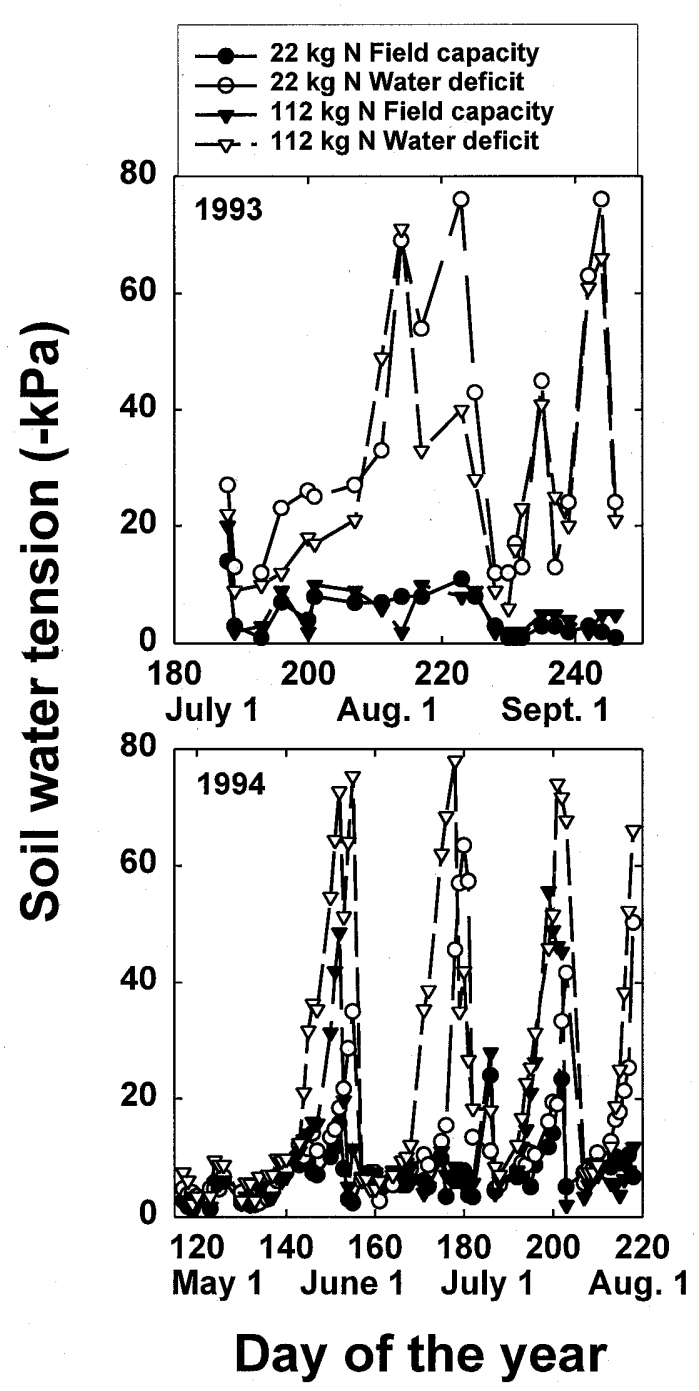

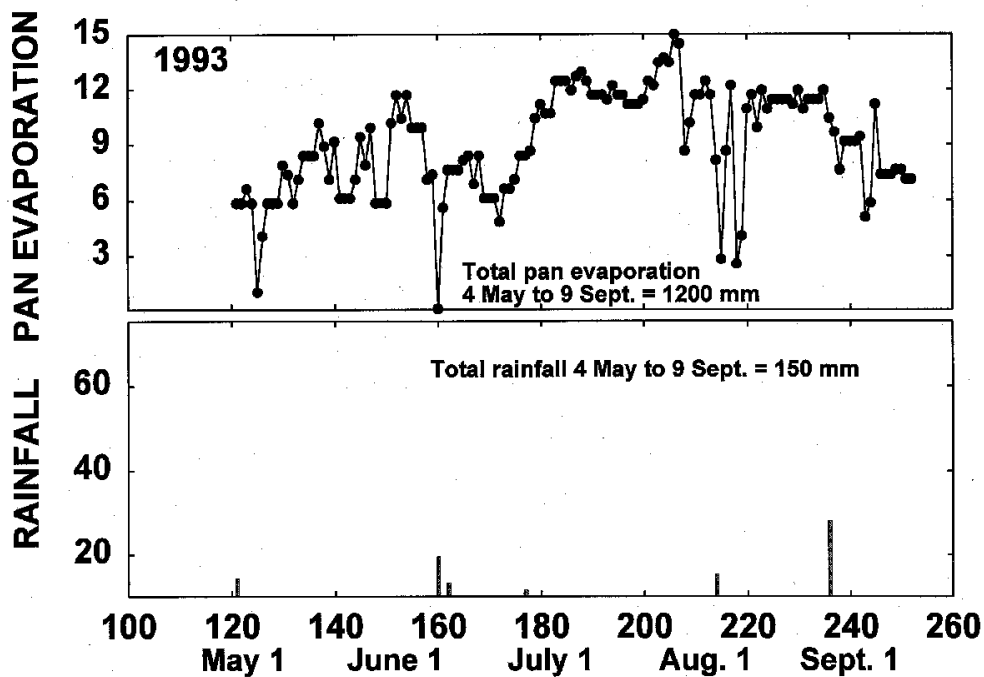

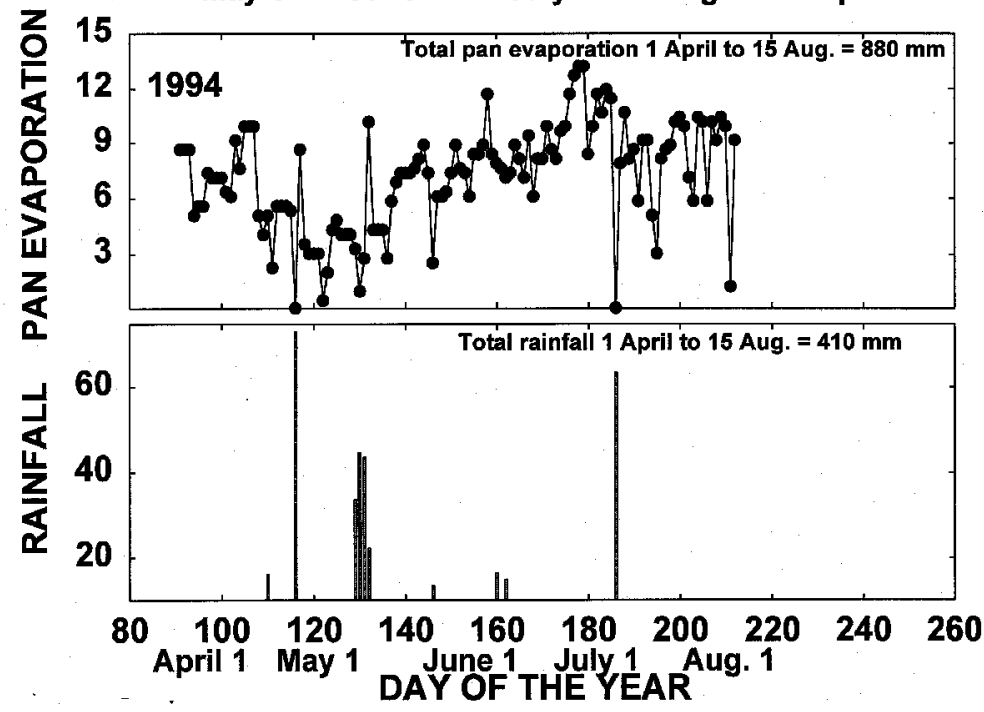

Fig. 1. Soil water tension (-kPa) as indicated by tensiome- Fig. 2. Daily open pan evaporation and rainfall (mm) during 4 May ters placed 30-cm deep in the soil of each lysimeter. Data points are averages of 4 replicate lysimeters.

(planting) to 9 September (harvest), 1993 and 1 April (greenup) to 20 August (harvest) 1994. and pan evaporation was greater during the 1993 growing season compared to 1994 (Fig. 2).

We tried to time photosynthesis measurements to coincide with periods of water deficit to document effects on physiological function; however, because of limited time and climatic conditions (measurements were made between 1000 and 1400 hours on clear days), we were able to document water-deficit effects on photosynthetic rates only on 12 and 30 August in 1993 and 29 June, 22 July, and 10 August in 1994. Switchgrass maintained relatively high rates of photosynthesis on 17 and 26 July 1993, which were not affected by $\mathrm{N}$ or water level (Table 1) and were similar to rates reported by Wullschleger et al.
(1996) for Alamo switchgrass grown in the field.

On 12 August 1993, after water was withheld for 15 days, photosynthetic rate of plants in the water-deficit treatment was only $10 \%$ of that for plants in the fieldcapacity treatment, whereas xylem pressure potentials dropped from about -1.6 to -3.3 $\mathrm{MPa}$. When all lysimeters were rewatered and plants allowed to recover until 20 August, photosynthetic rates and xylem pressure potential recovered to pre-stress levels. On 24 and 27 August, time and atmospheric conditions allowed us to obtain measurements only from the waterdeficit treatments. Photosynthetic rates were lower on these dates than on 20 August, indicating a developing water deficit. On 30 August, it appeared that water deficit significantly reduced photosynthetic rates and xylem pressure potential compared to the field-capacity treatment.

In 1994, photosynthetic rates and xylem pressure potential were reduced in waterdeficit treatments on 29 June, 22 July, and 10 August. On 22 July, only the high-N water-deficit treatment had significantly lower photosynthetic rates and xylem pressure potential than other treatments, whereas on 29 June and 10 August, both low- and high-N water-deficit treatments had lower photosynthetic rates and xylem pressure potential. Rainfall was abundant during April and May (Fig. 2) and precluded the development of significant soil water deficits in the spring. 
Table 1. Photosynthetic rates, xylem pressure potential, and soil moisture in each treatment on several dates in 1993 and 1994

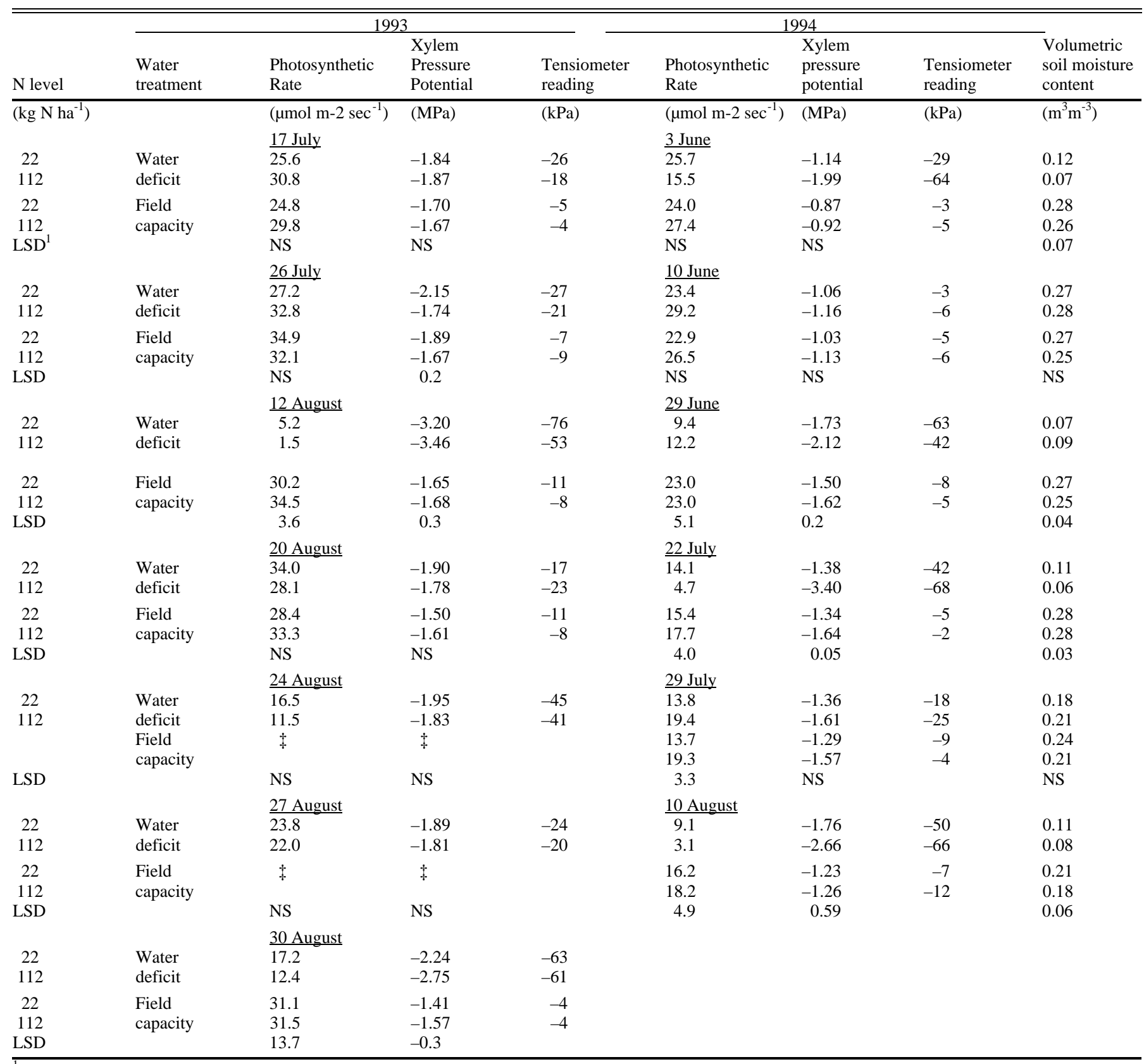

${ }^{1} \mathrm{LSD}=$ least significant difference at $\mathrm{P}<0.05$. $\ddagger$ Data were not taken.

Although we were not able to measure photosynthetic rates as often as we would have liked, it was clear that the waterdeficit and field-capacity treatments differed in soil water levels and that these differences affected physiological function of switchgrass. When soil water tension was less than about $-45 \mathrm{kPa}$, xylem pressure potential and photosynthetic rates were severely reduced indicating significant plant stress. Knapp (1985) reported photosynthesis rates near zero for switchgrass plants under severe water deficit (xylem pressure potential $<-2.0 \mathrm{MPa}$ ) on the Konza prairie in Kansas.

\section{Plant Dry Weight}

In 1993, the dry weight of individual switchgrass plants was not affected $(\mathrm{P}<$ 0.05 ) by water or $\mathrm{N}$ inputs. Plant spacing had the largest effect on plant dry weight and all treatments increased linearly in weight with increased plant spacing (Fig. 3). During 1994, however, switchgrass plants responded strongly to increased $\mathrm{N}$ fertilizer, but not to additional water. Switchgrass plants increased in dry weight with increased plant spacing, but the response (slope of the regression line) was nearly doubled with increased $\mathrm{N}$ fertilizer.
Thus, neither increased water nor $\mathrm{N}$ fertilizer were able to overcome the aboveground competition among plants at the higher plant densities.

The absence of a response in dry weight of seeding year switchgrass plants to or $\mathrm{N}$ input may indicate that the soil pool of $\mathrm{N}$ was adequate and that the young plants were able to explore and exploit a large volume of soil. In 1994, plants probably had a fully developed root system, which was able to draw more resources. Root dry weight was significantly higher for the $112 \mathrm{~kg} \mathrm{~N}$ treatment than in the low-N 


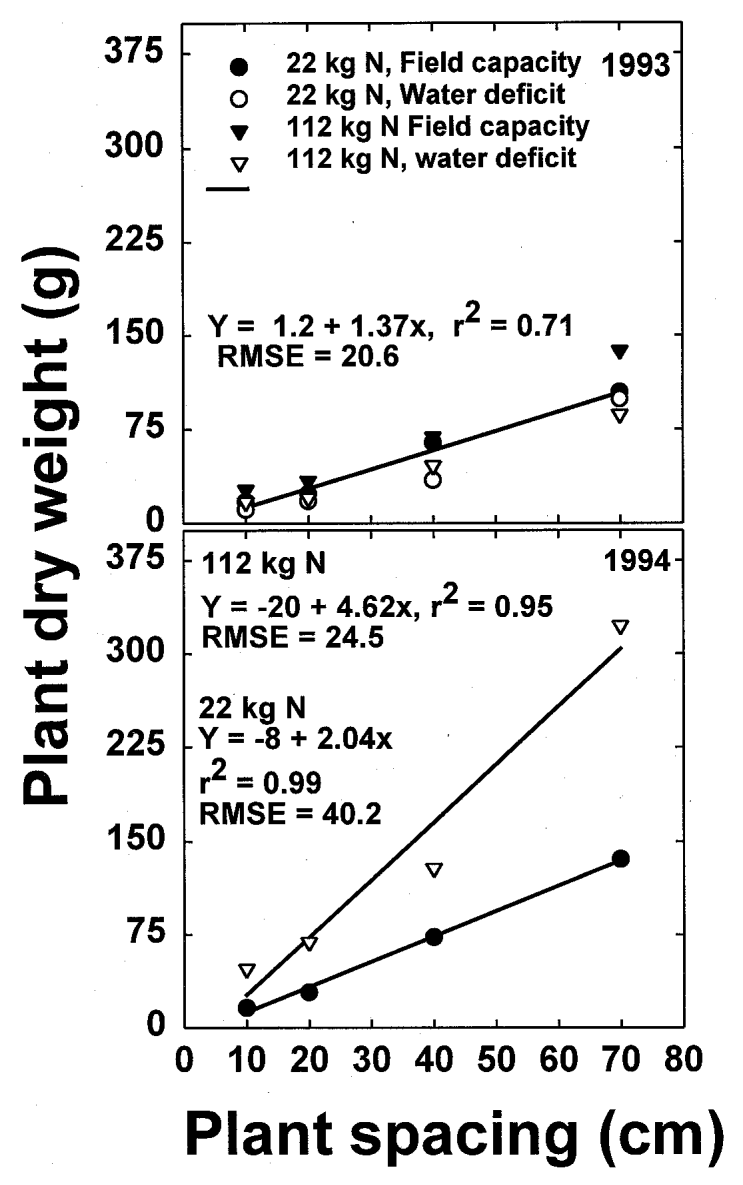

Fig. 3. Yield of dry matter per plant at $2 \mathrm{~N}$ and water levels in response to plant spacing. Data points in 1994 are the averages of 2 water treatments for each $\mathbf{N}$ level. RMSE = root mean square error.

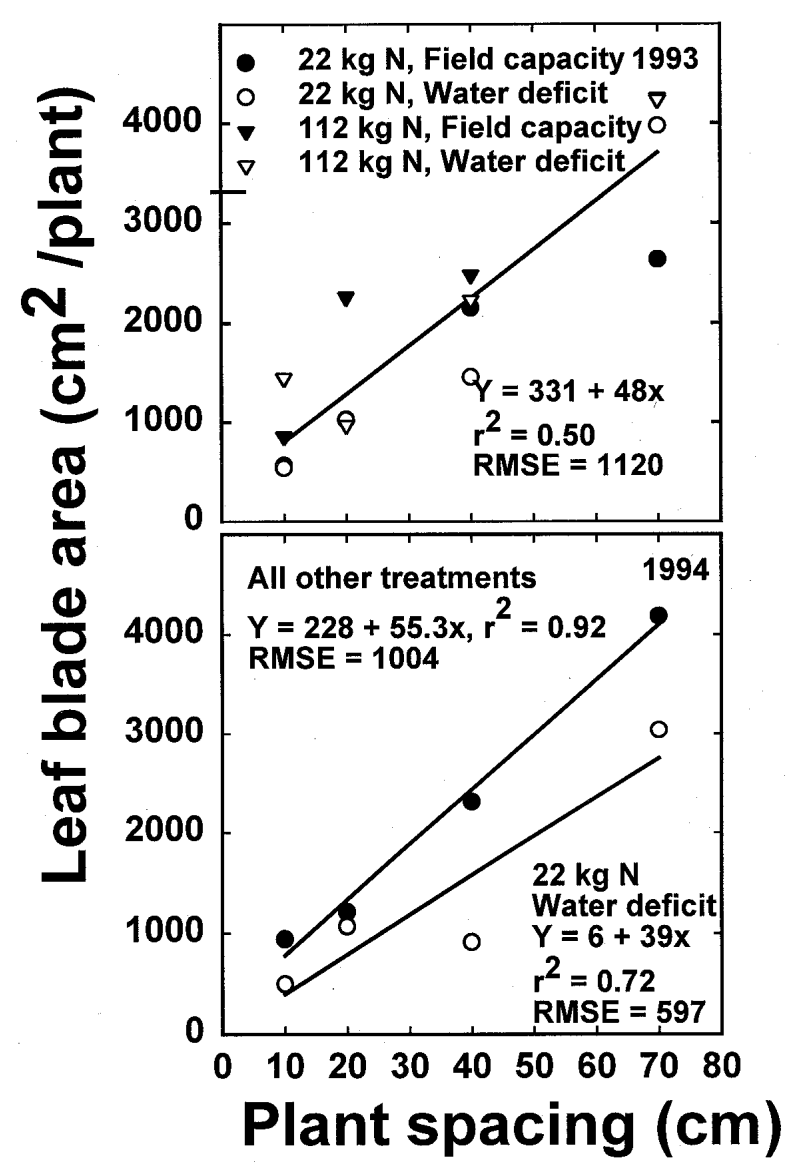

Fig. 4. Leaf blade area per plant at $2 \mathrm{~N}$ and water levels in response to plant spacing. There was no significant difference among the water treatments at $112 \mathrm{~kg} \mathrm{~N}$ and the $22 \mathrm{~kg} \mathrm{~N}$ field capacity water treatment, thus, these data were averaged for the regression response line. RMSE = root mean square error. treatment at the end of the season in 1994 , but was not affected by water level (Table 2). In 1993, all treatments were watered until 7 July to assure establishment. Significantly lower soil moisture tensions occurred after this, but all treatments were watered again on 12 August. Thus despite documenting significant differences in photosynthetic rates between water treatments on some dates (Table 1), the water deficit periods may not have been long enough to significantly reduce plant yields. Lower yields in 1993 compared to 1994 were a result of slow seedling growth and a shorter growing season (May to August in 1993 and March to September in 1994).

Leaf area per plant increased linearly with increasing plant spacing in 1993, but there were no significant differences among $\mathrm{N}$ or water treatments (Fig. 4). During 1994 , the leaf area of plants grown with low $\mathrm{N}$ and under water deficit responded less (smaller regression slope) to wider

Table 2. Dry weight of switchgrass roots to a 60-cm depth in August 1994 as affected by nitrogen rate and soil water level.

\begin{tabular}{|c|c|c|c|}
\hline \multirow[b]{2}{*}{ Water treatment } & \multicolumn{2}{|c|}{ Nitrogen level $\left(\mathrm{kg} \mathrm{ha}^{-1}\right)$} & \multirow[b]{2}{*}{ Mean } \\
\hline & 22 & 112 & \\
\hline & \multicolumn{3}{|c|}{ - } \\
\hline Field capacity & 11700 & 15300 & 13500 \\
\hline Water deficit & 9900 & 13500 & 11700 \\
\hline $\operatorname{Mean}^{1}$ & $11000 \mathrm{a}$ & $14400 \mathrm{~b}$ & \\
\hline SEM & \multicolumn{2}{|c|}{1200} & \\
\hline
\end{tabular}

${ }^{1}$ Means are significantly different at $\mathrm{P}<0.05$. plant spacing than the other treatments, which were not significantly different.

Leaf $\mathrm{N}$ concentration varied among years and treatments (Table 3). In 1993, plants grown with high $\mathrm{N}$ and under water deficit had one-third greater $\mathrm{N}$ concentration than other treatments. In 1994, there was no effect of water deficit, but the 112$\mathrm{kg} \mathrm{N}$ treatment had $36 \%$ greater leaf $\mathrm{N}$ than the 22-kg N treatment. There was an interaction among $\mathrm{N}$ and water treatments in leaf $\mathrm{N}$ concentration. Leaf $\mathrm{N}$ was not different between water treatments at the 22-kg N treatment, whereas leaf $\mathrm{N}$ increased with water deficit in the $112-\mathrm{kg}$ $\mathrm{N}$ treatment.

\section{Tiller Dynamics}

Tiller number per plant increased linearly with increasing plant spacing and was not affected by $\mathrm{N}$ or water inputs in either year (Fig. 5). Thus, differences in yield per plant among treatments in 1994 probably resulted from increased tiller size rather than tiller number. Moreover, tiller 


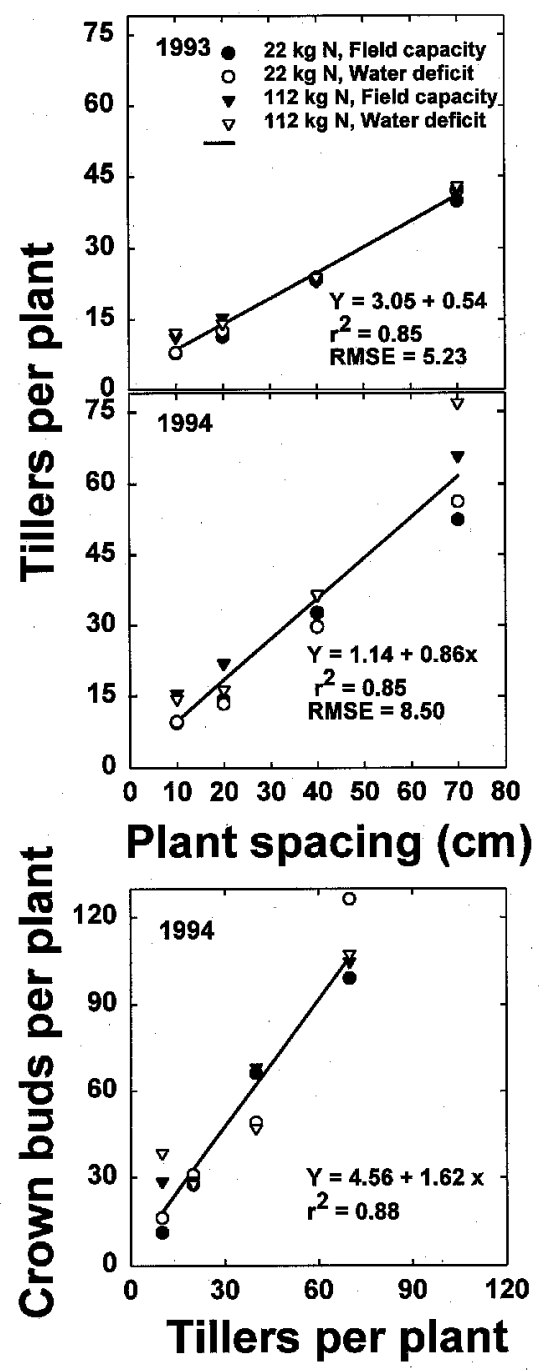

Fig. 5. Number of tillers per plant at $2 \mathrm{~N}$ and water levels in response to plant spacing in 1993 and 1994, and number of visible buds on the plant crown after harvest in 1994. RMSE = root mean square error.

number seemed to be affected more by aboveground competition than by competition for belowground resources. Similar to tiller number, the number of visible buds on the plant crown after harvest in 1994 increased linearly with increasing plant spacing and was not affected by $\mathrm{N}$ or water inputs (Fig. 5).

The pattern of tillering during the 1993 season was different among plant spacings (Fig. 6). Plants at the 40 and $70 \mathrm{~cm} \mathrm{spac-}$ ings increased greatly in tiller number from July to September. At the 2 lower plant spacings, there was a small increase in tiller number during June, but tiller number remained relatively constant after that. Peak tiller recruitment occurred during early May and early July for plants at the 40 and $70 \mathrm{~cm}$ spacings in 1994 . At the 10

Table 3. Concentration of $\mathrm{N}$ in leaf blades of switchgrass in 1993 and 1994 as affected by nitrogen rate and soil water level.

\begin{tabular}{|c|c|c|c|}
\hline \multirow[b]{2}{*}{ Water treatment } & \multicolumn{2}{|c|}{ Nitrogen level $\left(\mathrm{kg} \mathrm{ha}^{-1}\right)$} & \multirow[b]{2}{*}{ Mean } \\
\hline & 22 & 112 & \\
\hline \multicolumn{4}{|c|}{ - } \\
\hline & & 1993 & \\
\hline Field capacity & 8.2 & 10.8 & $9.5 \mathrm{a}$ \\
\hline Water deficit & 11.3 & 15.1 & $13.2 \mathrm{~b}$ \\
\hline Mean $^{1}$ & $9.8 \mathrm{a}$ & $13.0 \mathrm{~b}$ & \\
\hline \multirow[t]{2}{*}{ SEM } & & 1.11 & \\
\hline & & 1994 & \\
\hline Field capacity & $5.8 \mathrm{a}$ & $7.1 \mathrm{~b}$ & 6.4 \\
\hline Water deficit & $5.5 \mathrm{a}$ & $8.0 \mathrm{c}$ & 6.8 \\
\hline Mean & $5.6 \mathrm{a}$ & $7.6 \mathrm{~b}$ & \\
\hline SEM & & 0.81 & \\
\hline
\end{tabular}

${ }^{1}$ Means are significantly different at $\mathrm{P}<0.05$.

and $20 \mathrm{~cm}$ spacings, there was no spring peak in tiller number, but there was a pronounced increase in tiller number in July. The increase in tiller number during May at the 40 and $70 \mathrm{~cm}$ spacings could have been from rhizomes and crown buds formed during the previous fall, whereas the increase in July may have been from axillary buds. Thus, at all plant spacings, switchgrass was able to initiate and maintain tillers until August, after which tiller mortality increased. Late-formed tillers may not have been able to develop functional roots. When new tillers form, they obtain water via the parent plant until they develop functional adventitious roots (Carman and Briske, 1982). If the root system does not develop, the tillers will die.

\section{Morphological \\ Development}

Developmental stage of switchgrass plants increased with increasing plant spacing in 1993 (Fig. 7). Water deficit retarded morphological development, whereas $\mathrm{N}$ treatment had no effect. Plants in the water-deficit treatment had delayed inflorescence emergence and reproductive development compared with the field-capacity treatment (Fig. 8). In 1994, developmental stage responses to plant spacing dif- fered between $\mathrm{N}$ treatments, but was not affected by water treatments (Fig. 7). Switchgrass plants had a lower developmental stage in the $22-\mathrm{kg} \mathrm{N}$ treatment compared with $112 \mathrm{~kg} \mathrm{~N}$ at the 10 - and $20-\mathrm{cm}$ spacings. There were no differences among treatments at the 40 and 70$\mathrm{cm}$ spacing. Plants in the high $\mathrm{N}$ treatment exerted inflorescences earlier than low-N plants in 1994 (Fig. 8).

The pattern of morphological development in this experiment was similar to that reported by Sanderson (1992) and Sanderson and Wolf (1995). Nitrogen addition to individual switchgrass plants on the Konza Prairie increased the number of tillers that flowered and produced seed (Hartnett 1993) and increased plant density (in a pot experiment in the greenhouse)

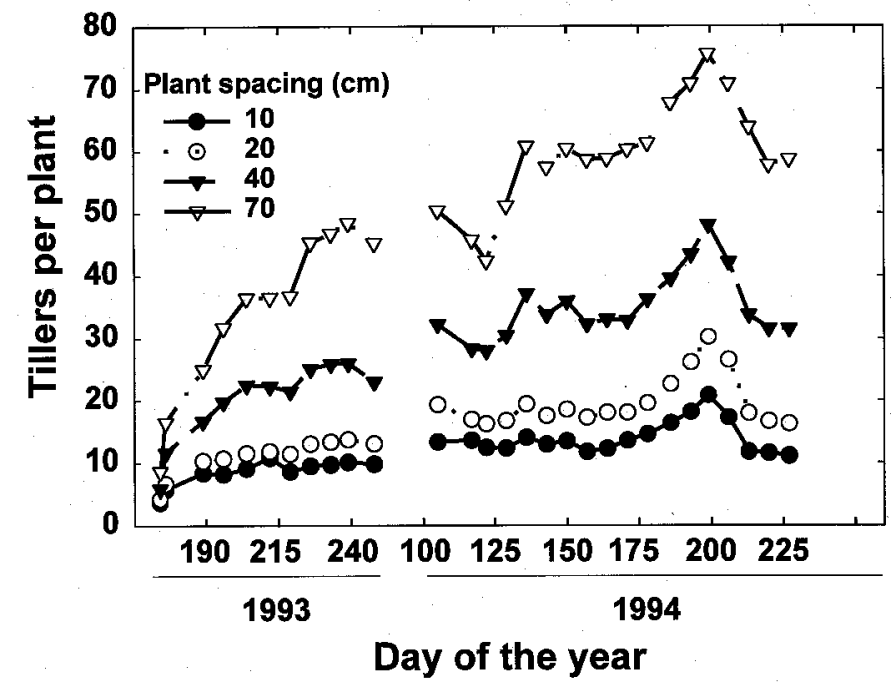

Fig. 6. Tillering patterns of switchgrass from planting to harvest in 1993, and from 15 April to 15 August 1994. Data points are averages of $2 \mathrm{~N}$ and water levels and 4 replicates. 


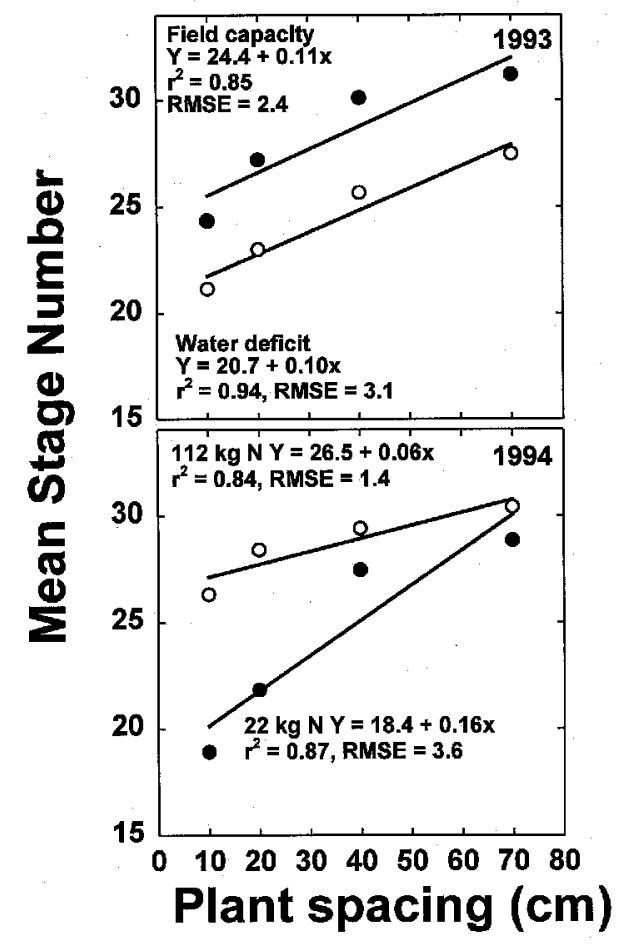

Fig. 7. Mean stage of morphological development at harvest at $2 \mathrm{~N}$ and water levels in response to plant spacing. In 1993, the data points are averages of $2 \mathrm{~N}$ levels, whereas in 1994 the data points are averages of 2 water treatments. Stage number $15=$ vegetative plants with 5 elongated internodes; $20=$ boot stage; $25=50 \%$ of the inflorescence emerged; $30=$ anthesis. Morphological stages determined according to Sanderson (1992).

reduced reproductive growth of switchgrass (Hartnett 1989). Sanderson (1992) and Sanderson and Wolf (1995) reported no differences between wet and dry years in switchgrass development patterns. Thus, switchgrass development may be more sensitive to water stress during the seeding year than in subsequent production years after the plants have fully established.

Our data support the suggestion of Hartnett (1993) that $\mathrm{N}$ availability does not affect the rate of increase in clonal growth of switchgrass. Water availability and the canopy light environment of individual switchgrass plants were shown to be the dominant controls of individual plant tiller growth and dynamics (Hartnett, 1993). Our data were not clear-cut regarding the effects of water availability. We found that water and $\mathrm{N}$ affected tiller size, whereas tiller number was influenced mainly by interplant competition for aboveground resources.

This concept has practical application in managing stands of switchgrass that have

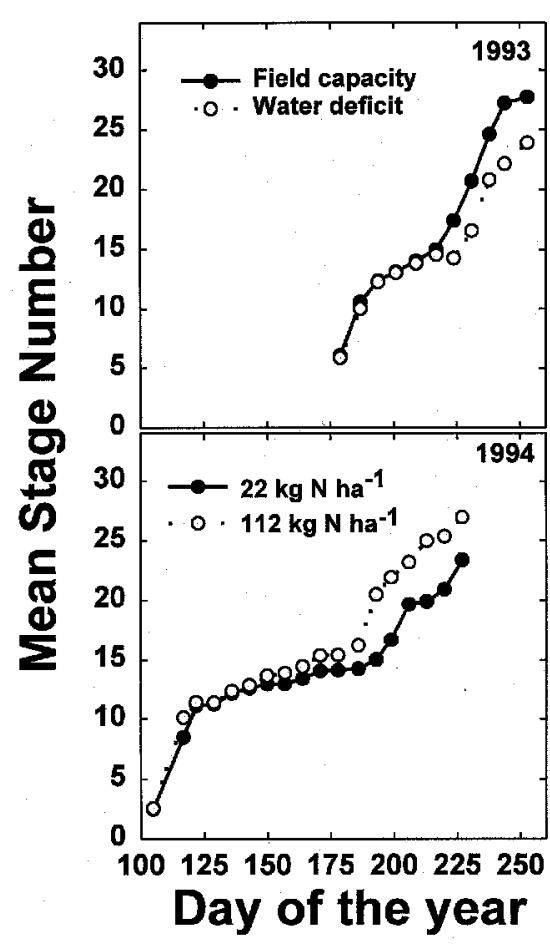

Fig. 8. Morphological development (mean stage number) pattern of switchgrass as affected by soil water level in 1993 and $\mathbf{N}$ fertility in 1994. Stage number $5=$ vegetative plants with 5 fully expanded leave blades and no elongated internodes; $10=$ beginning of internode elongation; 15 $=$ vegetative plants with 5 elongated internodes; 20 = boot stage; $25=\mathbf{5 0 \%}$ of the inflorescence emerged; $30=$ anthesis. Morphological stages determined according to Sanderson (1992).

decreased in density by natural thinning or mismanagement. If stands have thinned to a point at which individual plants are not able to compensate by increased tillering, production cannot be increased from these stands by adding more water or $\mathrm{N}$ fertilizer.

\section{Literature Cited}

Ballare, C.L., A.L. Scopel, and R.A. Sanchez. 1995. Plant morphogenesis in canopies, crop growth, and yield. Hort Sci. 30:11721181.

Carman, J.G. and D.D. Briske. 1982. Root initiation and leaf elongation of dependent little bluestem tillers following defoliation. Agron. J. 74:432-435.

Epstein, H.E., W.K. Lauenroth, I.C. Burke, and D.P. Coffin. 1996. Ecological responses of dominant grasses along two climatic gradients in the Great Plains of the United States. J. Veg. Sci. 7:777-788.

Hartnett, D.C. 1989. Density and growth-stage dependent responses to defoliation in two rhizomatous grasses. Oecologia 80: 414-420.

Hartnett, D.C. 1993. Regulation of clonal growth and dynamics of Panicum virgatum (Poaceae) in tallgrass prairie: Effects of neighbor removal and nutrient addition. Amer. J. Bot. 80:1114-1120.

Knapp, A.K. 1985. Effect of fire and drought on the ecophysiology of Andropogon ger ardii and Panicum virgatum in a tallgrass prairie. Ecol. 66:1309-1320.

McLaughlin, S.B. and M.E. Walsh. 1998. Evaluating environmental consequences of producing herbaceous crops for bioenergy. Biomass and Bioenergy 14:317-324.

Murphy, J.S. and D.D. Briske. 1992. Regulation of tillering by apical dominance: chronology, interpretive value, and current perspectives. J. Range. Manage. 45:419-429.

Nelder, J.A. 1962. New kinds of systematic designs for spacing experiments. Biometrics 18:283-307.

Sanderson, M.A. 1992. Morphological development of switchgrass and kleingrass. Agron. J. 84:415-419.

Sanderson, M.A. and D.D. Wolf. 1995. Morphological development of switchgrass in diverse environments. Agron J. 87:908-915.

Sanderson, M.A., R.L. Reed, S.B. McLaughlin, S.D. Wullschleger, B.V. Conger, D.J. Parrish, D.D. Wolf, C. Taliaferro, A.A. Hopkins, W.R. Ocumpaugh, M.A. Hussey, J.C. Read, and C.R. Tischler. 1996. Switchgrass as a sustainable bioenergy crop. Bioresource Tech. 56:83093.

SAS 1988. SAS Institute Inc. SAS/STAT User's Guide, Release 6.03. SAS, Cary, N.C.

Scholander, P.F., H.T. Hammel, E.D. Bradstreet, and E.A. Hemmingsen. 1965. Sap pressure in vascular plants. Sci. (Wash. D.C.) $148: 339-346$.

Wullschleger, S.D., M.A. Sanderson, S.B. McLaughlin, D.P. Bindar, and A.L. Rayburn. 1996. Photosynthetic rates and ploidy levels among populations of switchgrass. Crop Sci. 36:306-312. 


\title{
Effects of nitrogen fertilization in leafy spurge root architecture
}

\author{
KIRSTIN RINGWALL, MARIO E. BIONDINI, AND CAROLYN E. GRYGIEL
}

Authors are undergraduate student, professor, and associate professor, Department of Animal and Range Sciences, North Dakota State University, Fargo, N.D. 58105. Request for reprints should be sent to M.E. Biondini.

Abstract

There is a dearth of information concerning the degree to which the amounts, periodicity, and spatial patterns of $\mathrm{N}$ applications can be manipulated to alter the rooting strategy of leafy spurge, and thus make it more susceptible to chemical and biological controls. This study was designed with the following objectives: (1) determine the effect of patchy $\mathbf{N}$ fertilization on shoot and root biomass, root distribution by depth, root plasticity, and the ratio of coarse vs. fine roots of leafy spurge; and (2) determine how leafy spurge scales root biomass to root lateral spread and root surface area, as well as how these scaling patterns are affected by $\mathbf{N}$ fertilization. The root architecture, plasticity, and response to patchy $\mathbf{N}$ fertilization was evaluated in 3 separate experiments conducted in large containers. Patchy fertilization did not alter the morphological characteristics of leafy spurge roots, but did cause a reduction in root biomass and a drastic change in the distribution of the root surface area within the plant's rooting volume. Fertilization both doubled the percentage of roots located in the top $10 \mathrm{~cm}$ of soil and shifted it toward the fertilized patches.

Key Words: Leafy spurge fertilization, root plasticity, root lateral spread

Leafy spurge (Euphorbia esula L.) has evolved into an extensive weed control issue since first introduced to North America over 130 years ago (Selleck et al. 1962). The majority of current eradication strategies fall into 3 major categories (Lym and Zollinger 1995): physical (mowing, cultivation, competition), biological (grazing, insects), and chemical (herbicides). Leafy spurge eradication, however, has proven difficult primarily due to spurge's ability to persist under adverse conditions, a result of an efficient reproductive system and an extensive root system (Raju et al. 1963, Bowes and Thomas 1978, Galitz and Davis 1983, Messersmith 1983, Lajeunesse et al. 1995, Lym and Zollinger 1995). The heterorhizic complex root system of leafy spurge includes long roots having indeterminate longitudinal growth and the ability to undergo secondary (cambial) growth and short roots having limited cambial activity (Raju et al. 1963). Vertical ("long") roots can grow to depths up to $8.5 \mathrm{~m}$, while horizontal roots can have lateral spreads of up to $5 \mathrm{~m}$ (Lajeunesse et al. 1995, Galitz and Davis 1983). The 2 primary modes of reproduction are through regenerative adventitious root buds and dehis-

Research was funded by the North Dakota EPSCoR Science Bound Awards Program and a grant from the National Science Foundation (DEB-9624928).

Manuscript accepted 30 May 1999.
Resumen

Tenemos al presente un conocimiento limitado de como la cantidad, periodicidad, y distribución espacial de la fertilización con $\mathrm{N}$ puede ser manipulada para alterar la distribución de las raíces de leafy spurge y como consecuencia hacerla mas vulnerable a los controles biologicos y quimicos. Este estudio fue diseñado con los siguientes objetivos: (1) determinar como la aplicación espacialmente irregular de $\mathbf{N}$ afecta la producción de hojas, tallos, $\mathbf{y}$ raíces, la distribución de raíces a diferentes profundidades en el suelo, la plasticidad de las raíces, y la proporción de raíces gruesas en comparación con raices finas de leafy spurge; y (2) determinar la relación entre la biomasa, la expanción lateral y la superficie de las raices en cuestion, y como esa relación es afectada por la fertilización con $\mathbf{N}$. La estructura, plasticidad, y la respuesta de raices a la distribución irregular de $\mathbf{N}$ fue evaluada en 3 experimentos conducidos en macetas grandes. La aplicación espacialmente irregular de $\mathbf{N}$ no afectó las caracteristicas morfologicas de las raices de leafy spurge, pero resultó en una reduccion en la proporción de la biomasa de la planta destinada a las raíces y un drastico cambio en la distribución espacial de las raíces dentro del volumen de suelo explorado por la planta. La fertilización simultaneamente duplicó el porcentaje de raices localizadas en los primeros $10 \mathrm{~cm}$ del suelo, y las concentró en las porciones del suelo fertilizadas.

cence of seed capsules (up to $5 \mathrm{~m}$. from the parent plant) (Galitz and Davis 1983).

Nitrogen $(\mathrm{N})$ plays a key role in the development and competitive abilities of plant species (Haynes et al. 1986), and the root morphological development of spurge has proven highly responsive to variant $\mathrm{N}$, including responses in root:shoot ratios, percentage "long" and lateral roots, and number of root and shoot buds produced (McIntyre and Raju 1967). Recent studies have also shown that soil $\mathrm{N}$ plays a critical role in the overwintering strategy in leafy spurge root systems, and that seasonal fluctuations of root $\mathrm{N}$ are accurate indicators of plant health and determinants of potential regenerative vigour (Lym and Messersmith 1993, McIntyre and Raju 1967, Cyr and Bewley 1989, 1990). Furthermore, fall $\mathrm{N}$ fertilization has been shown to increase the effectiveness of spring applied herbicides (Regimbal and Martin 1985).

A renewed interest has arisen among plant ecologists in determining how root morphology and root plasticity (ability to redirect root growth to areas of high nutrient concentration) can affect plant performance and composition in patchy environments, and how the spatial distribution of nutrients themselves can alter biomass allocation to roots and root architecture (Campbell et al., 1991; Caldwell 1994; Jackson and Caldwell 
1996). Results from these studies have suggested that the ability of plants to compete for soil resources is highly dependent on: (a) the spatial distribution, concentration, and supply rate of soil nutrients; (b) the volume of soil explored by their root system; (c) the density and spatial patterns of root surfaces within the rooting volume; and (d) the rate of nutrient uptake. The available information for most native species and leafy spurge, however, is still quite limited.

Significant amounts of research have been done on leafy spurge physiology, eradication methods, and root organogenesis, but few studies have concerned themselves with elucidating how the competitive ability of leafy spurge can be influenced through interactions among the spatial distribution of soil nutrients (i.e. soil $\mathrm{N}$ ), root architecture, and root plasticity. In particular there is a dearth of information concerning the degree to which the amounts, periodicity, and spatial patterns of $\mathrm{N}$ applications can be manipulated to alter the rooting strategy of leafy spurge, and thus make it more susceptible to chemical and biological controls. This study, thus, was designed with the following objectives:

1. Determine the effect of patchy $\mathrm{N}$ fertilization on shoot and root biomass, root distribution by depth, root plasticity, and the ratio of coarse vs. fine roots.

2. Determine how leafy spurge scales root biomass to root lateral spread and root surface area, as well as how these scaling patterns are affected by $\mathrm{N}$ fertilization.

\section{Materials and Methods}

The root architecture, plasticity, and response to patchy $\mathrm{N}$ fertilization of leafy spurge was evaluated in 3 separate experiments conducted from 1995 to 1997.

\section{Experiments 1 and 2}

Leafy spurge root rhizomes were randomly collected from a sandy soil type in the Sheyenne National Grasslands and planted in $60 \times 60 \times 60 \mathrm{~cm}$ wooden boxes (one $2.5 \mathrm{~cm}$ rhizome, with a bud, per box) equipped with detachable sides and filled with washed river sand from the Buffalo River, N.D. The boxes had two, $2 \mathrm{~cm}^{2}$ hardware mesh panels inserted horizontally at depths of 10 and $30 \mathrm{~cm}$. The mesh was intended to keep the roots in place after the sand had been removed so accurate measurements of vertical and horizontal distributions could be made. Half of the boxes in each experiment were fertilized with Sierra ${ }^{\circledR}$ slow release fertilizer prills (N-P-K:16-8-12 plus minor nutrients) at a rate of $37.5 \mathrm{gN} / \mathrm{m}^{2}$. All prills were located in one side of the box (North), at $7.5 \mathrm{~cm}$ below the surface in a straight line half way between the plant and the outer edge of the container. The purpose of the design was to effectively test the degree to which root architecture was affected by nutrient patchiness. Before adopting this method, a series of preliminary tests were run to determine the design capability for maintaining nutrient patches. Nitrate $\left(\mathrm{NO}_{3}\right)$ was measured (due to its high mobility) for a 4 week trial period using different $\mathrm{N}$ concentrations. Although there was some movement of $\mathrm{NO}_{3}$, we were able to maintain gradients ranging from 15 to 400 ppm.

The experiments were arranged as a completely randomized design with two treatments, fertilized and not-fertilized, and 5 replications per treatment. The experiments were conducted, outdoors, from May to September of 1995 (Experiment 1), and repeated in 1996 (Experiment 2). At the end of each experiment we proceeded as follows: (1) above ground biomass was clipped at the surface level; (2) the sides of the boxes were removed and the sand washed out; and (3) roots were harvested by depth (0-10 and $10-60 \mathrm{~cm})$ and separated in two halves in accordance with the fertilization design. Aboveground biomass and roots were oven-dried for 12 hours at $60^{\circ} \mathrm{C}$ and weighed. In the first experiment, root subsamples by depth and halves were digitized using a Hewlett Packard high resolution scanner and analyzed for total root length, root diameter, and root surface area with the use of a Delta-T Scan imaging system.

\section{Experiment 3}

The third experiment was designed to determine how leafy spurge scales root biomass to root lateral spread. Cylindrical containers $(50 \mathrm{~cm}$ in diameter, $90 \mathrm{~cm}$ in depth) were fitted with 2 cylindrical dividers (15 and $30 \mathrm{~cm}$ in diameter) made of wire netting ( $1 \mathrm{~cm}$ mesh). The mesh system was used to accurately measure root biomass by depth at fixed horizontal distances of $0-7.5,7.5-15$, and $15-25 \mathrm{~cm}$ from the rhizome (one $2.5 \mathrm{~cm}$ rhizome, with a bud, per box). The containers were filled with pure silica sand and planted with leafy spurge rhizomes. Half of the containers were fertilized using the same design outlined in Experiments 1 and 2.

The experiment was organized as a completely randomized design with 2 treatments, fertilized and not-fertilized, and 6 replications per treatment. The experiment was conducted in the greenhouse from May to September (1997). Above ground biomass was clipped at the surface level. Roots were rinsed out while still in the containers and clipped on the basis of 18 locations determined by 3 categories: (1) North side (fertilized) vs. South side (notfertilized); (2) horizontal distance from rhizome $(0-7.5 \mathrm{~cm}, 7.5-15 \mathrm{~cm}$, and $15-25$ $\mathrm{cm})$; and (3) depth $(0-10 \mathrm{~cm}, 10-20 \mathrm{~cm}$, and $20-80 \mathrm{~cm})$. Above and below ground biomass were dried and weighed. Roots were scanned, digitized, and analyzed for total root length, root diameter, and root surface area using the same method discussed in the previous section.

\section{Statistical Analysis}

Statistical differences between fertilized and not-fertilized treatments in terms of above ground biomass, root biomass, and root biomass by depth were analyzed using a t-test. Differences in the proportion of root biomass between the North side (fertilized side in the fertilized treatment) and the South side within each treatment were analyzed using a paired t-test with a null hypothesis of $\mathrm{H}_{\mathrm{o}}=0.5$. The data in this case was transformed using the angular transformation (Bonham 1989). Combined P-values for the 3 experiments, where pertinent, were calculated using the Fisher test (Folks 1984). Differences in the distribution functions of root diameter vs. root surface area among treatments were tested using the Kolmogorov-Smirnov test (Sokal and Rohlf 1969). All results were considered significant at the $\mathrm{P}<0.05$ level.

The scaling relationship of root biomass with root surface area and root lateral spread were analyzed using an allometric model of the form $\boldsymbol{y}=\alpha^{*} \mathbf{R} \mathbf{B}^{\beta}$ where $\boldsymbol{y}$ is either root lateral spread (rls in $\mathrm{cm}$ ) or root surface area $\left(\mathrm{RSA}\right.$ in $\left.\mathrm{m}^{2}\right)$, and $\mathbf{R B}$ is root biomass $(\mathrm{g})$. The equation parameters were estimated with the use of linear regressions on the log-log transformations: $\ln (y)=\ln (\alpha)+\beta * \ln (R B)$.

\section{Results}

Total leafy spurge biomass was unaffected by fertilization in 2 of the 3 experiments (Fig. 1A). In Experiment 2, however, total biomass in the fertilized treatment was more than 3 times higher than in the notfertilized treatment, which resulted in a combined P-value for the 3 experiments of $\mathrm{P}<0.001$. Total root surface area in Experiments 1 and 3 averaged $0.63 \mathrm{~m}^{2}$, but there were no differences between the fertilized and not-fertilized treatment (Fig. 

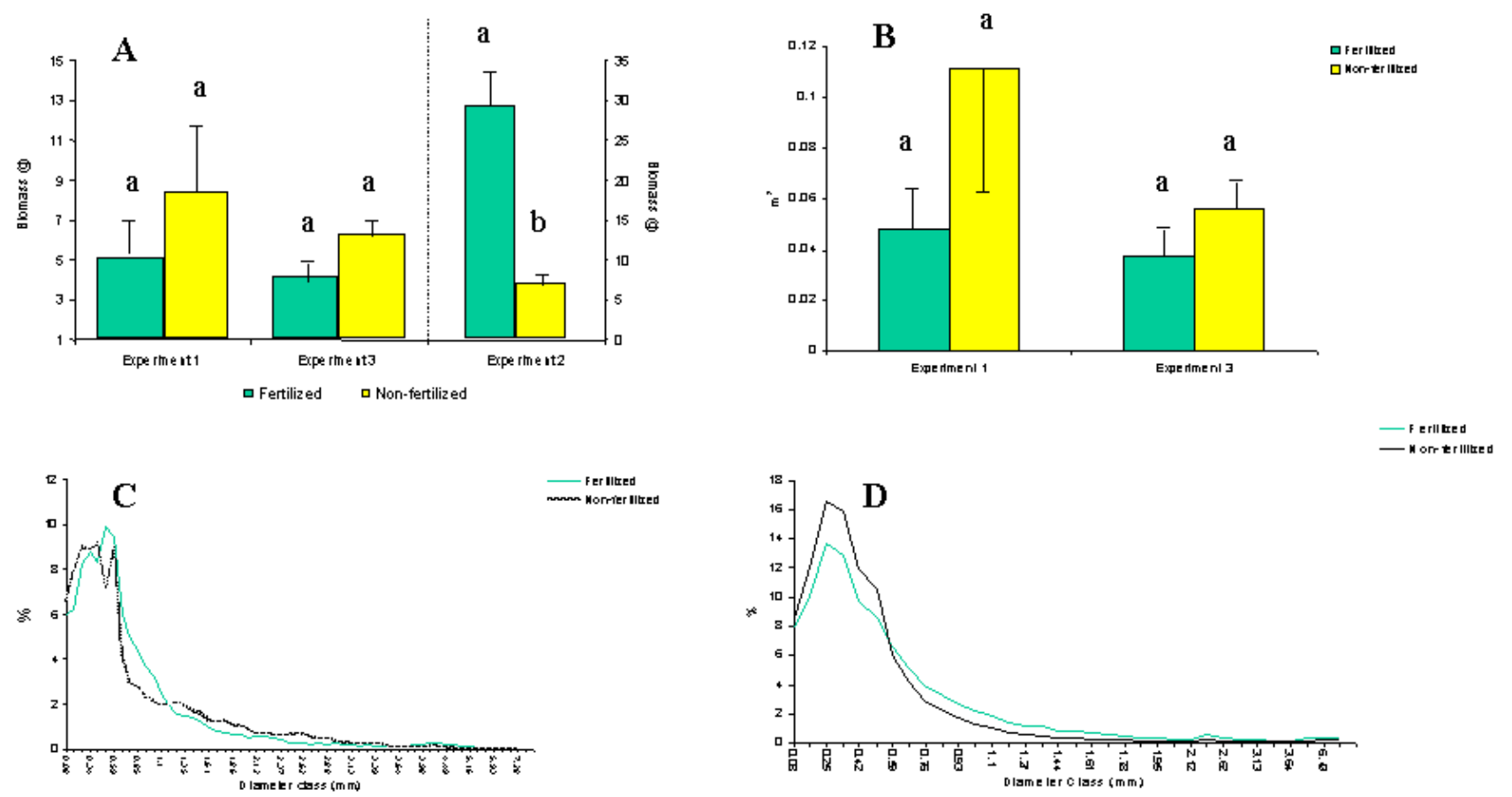

Fig. 1. Effects of fertilization on: A. Total plant biomass (g). B. Total root surface area $\left(\mathrm{m}^{2}\right)$. Percent distribution of total root surface area as a function of root diameter classes (in $\mathrm{mm}$ ) in experiment 1 (C) and experiment 3 (D). Treatments with different letters within an experiment are statistically different at the $P<0.05$ level. Vertical lines represent 1 SE.

1B). Fifty percent of the total root surface area in Experiment 1 and $70 \%$ in Experiment 2 (Figs. 1 C-D) were composed of very fine roots (diameters $<0.5$ $\mathrm{mm})$, but there were no differences in either experiment between the distribution of the root diameter classes of the fertilized vs. the not-fertilized treatments (Figs. $1 \mathrm{C}-\mathrm{D})$.

Root:shoot ratios and the vertical distribution of root biomass were significantly affected by fertilization (Figs. 2 A-C). In 2 of the 3 experiments fertilization reduced root:shoot ratio by an average of 50\%: 1.29 vs. 2.49 (Fig. 2A), and doubled the percentage of root biomass allocated to the first $10 \mathrm{~cm}$ of the soil profile: $31 \%$ vs. $15 \%$ (Figs. 2 B-C). The combined Pvalues for the 3 experiments were $\mathrm{P}<$ 0.001 and $P<0.006$ respectively. An analysis of data from Experiment 3, where 3 depths were available, showed that: (1) $70 \%$ or more of total root biomass was allocated below $20 \mathrm{~cm}$; and (2) leafy spurge allocated only $11 \%$ of root biomass at depths of $10-20 \mathrm{~cm}$, which was unaffected by fertilization (increases in root biomass in the $0-10 \mathrm{~cm}$ came from decreases in the $20-80 \mathrm{~cm}$ depth).

Leafy spurge showed a significant degree of root plasticity (Fig. 2D). In all 3 experiments leafy spurge allocated an average of $75 \%$ of its root biomass to the fertilized side of the containers in the fertilized treatments (Fig. 2D). No differences were found between the North and South sides in the not-fertilized treatments.

There was a significant allometric relationship between root biomass and root surface area, and root biomass and root lateral spread (Table 1). The equations for both the fertilized and not-fertilized treatments were remarkably similar showing very robust and stable scaling patterns. Fertilization, thus, did not affect the total area explored by the root system (Table 1) but simply changed the distribution of the roots within the given area (Figs. 2 B-D).

\section{Discussion and Conlusions}

Total biomass was unaffected by fertilization in 2 out of the 3 experiments, a result that was rather unexpected (Fig. 1A). Also interesting, was the fact that total biomass in Experiments 1 and 3 was very similar even though the experiments differed in the depth of the growth medium $(60 \mathrm{~cm}$ vs. $90 \mathrm{~cm})$, and location: outside vs. greenhouse. The total root surface area of these 2 experiments, furthermore, was also unaffected by fertilization (Fig. 1B). The statistical results in this case were caused by large standard errors, but there seems to be, nevertheless, a definite trend suggesting a decrease in root surface

Table 1. Allometric relationships of root lateral spread $(\mathrm{rsl}$ in $\mathrm{cm})$ and root surface area $(\mathrm{RSA}$ in $\mathrm{m}^{2}$ ) with root biomass ( $R B$ in $\mathrm{g}$ ).

\begin{tabular}{lccll}
\hline \hline Experiment & Treatment & Equation & $\mathbf{R}^{2}$ & P-value \\
\hline Experiment 1 (1995) & Fertilized & $R S A=0.0325 * R B^{0.9243}$ & 0.79 & 0.0028 \\
& Not-Fertilized & $R S A=0.03808^{*} R B^{1.08}$ & 0.85 & 0.025 \\
Experiment 3 (1997) & & & \\
& Fertilized & $R S A=0.0155^{*} R B^{0.95}$ & 0.83 & 0.031 \\
& Not-Fertilized & $R S A=0.0144 * R B^{0.94}$ & 0.94 & 0.032 \\
& Fertilized & $r l s=0.0616^{*} R B^{0.91}$ & 0.80 & 0.0000001 \\
& Not-Fertilized & $r s l=0.0641 * R B^{0.88}$ & 0.85 & 0.0000001 \\
\hline
\end{tabular}



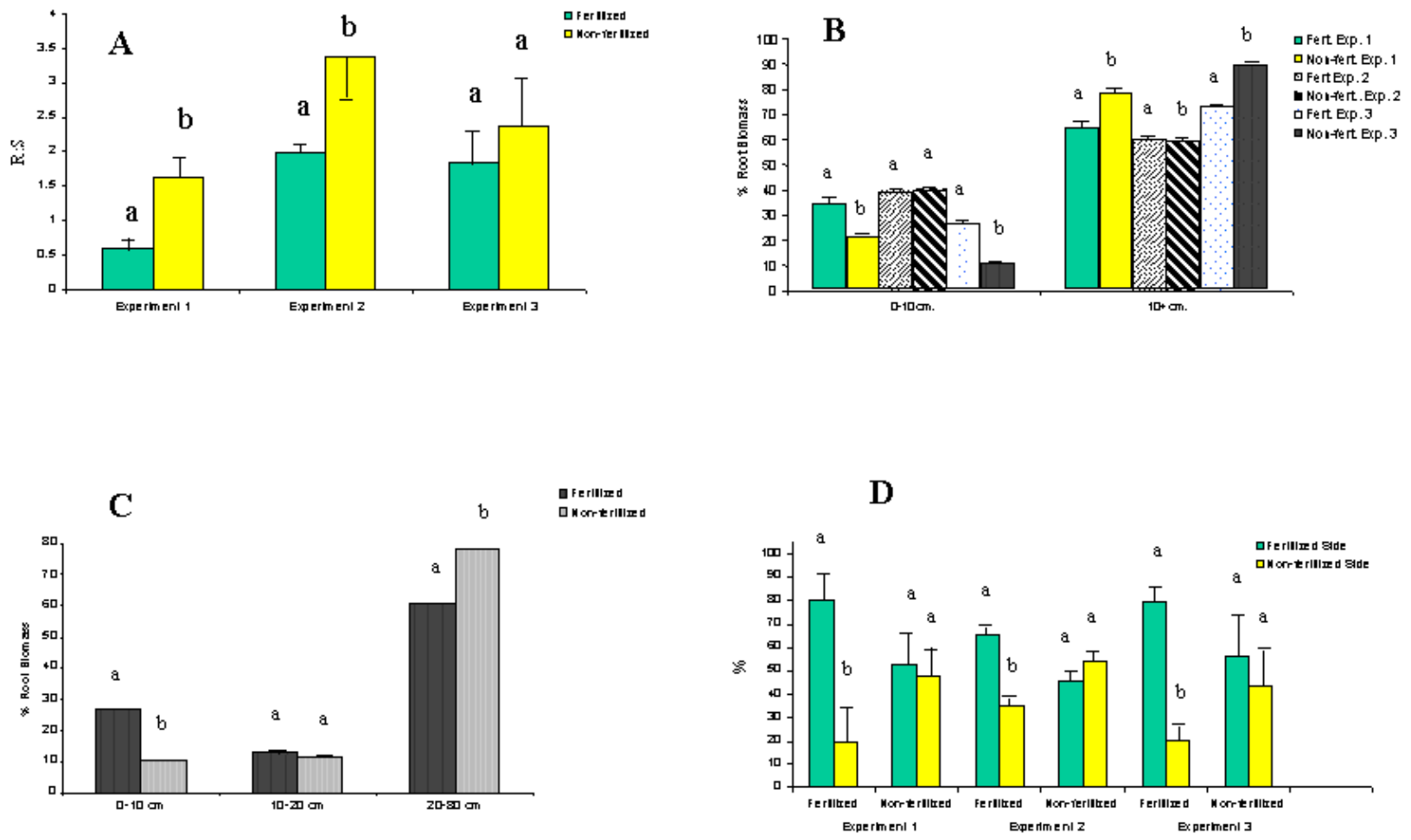

Fig. 2. Effects of fertilization on: A. Root:Shoot $(\mathrm{R}: \mathrm{S})$ ratio. B. Percent root biomass distribution in $0-10 \mathrm{~cm}$ and below $10 \mathrm{~cm}$ of depth for all 3 experiments. C. Percent root biomass distribution in the 0-10, 10-20, and $20-80 \mathrm{~cm}$ of depth for experiment 3. D. Percent biomass allocated to the fertilized and not-fertilized patches in the fertilized treatment and comparable areas in the not-fertilized treatment. Treatments with different letters within an experiment are statistically different at the $P<0.05$ level. Vertical lines represent 1 SE.

area with fertilization (Fig. 1B). This trend, however, was not caused by alterations in root morphology but rather by a decline in root biomass. This interpretation is supported by 3 pieces of evidence: (a) fertilization decreased the amount of plant biomass allocated to roots (Fig. 2A), but did not change the way fertilized and not-fertilized plants scaled root biomass to root surface area (Table 1); (b) there were no changes in average root diameter and diameter distribution classes as a result of fertilization (Figs. 1 C-D); and finally (c) there is a substantial body of both empirical and theoretical data that suggests a trade-off in the way plants allocate biomass to roots: under high nutrient conditions plants increase their biomass allocation to leaves and shoots at the expense of roots, thus reducing their total root surface area (Tilman 1990, Ryser and Lambers 1995, Fransen et al. 1998, but also see Shipley and Peters 1990 for a different perspective). The lack of change in the distribution of root diameter classes as a result of fertilization was rather unexpected (Figs. 1 C-D). For most plants, fertilization tends to increase the average diameter of roots since, when nutrient concentration is not a limiting factor, thicker roots have the small axial conductance and high transport capacity needed to fully exploit a high nutrient environment (Ryser and Lambers 1995).

Patchy fertilization, in summary, did not change the morphological characteristics of leafy spurge roots. Its main effect was a reduction in root biomass and a drastic change in the distribution of the root surface area within the plant's rooting volume (Figs. 2 C-D). Fertilization both doubled the percentage of roots located in the top $10 \mathrm{~cm}$ of soil and shifted it toward the fertilized patches. This level of root plasticity is considerably higher than that observed in many other plants: a 3:1 ratio of root biomass in the fertilized vs. notfertilized patches for leafy spurge (Fig. 2D) vs. an average of 1.5:1 reported in the literature for a variety of grasses and forbs (see Larigauderie and Richards 1994, Caldwell 1994, Fransen et al. 1998 and their respective citations).

The high vertical and horizontal plastic response shown by leafy spurge roots, while advantageous for nutrient acquisition, can potentially constitute a weakness. A considerable advantage of leafy spurge, is that the depth distribution pattern of its root system makes it less susceptible to direct competition from the roots of native species: more than $60 \%$ of the root bio- mass of most grasses and forbs native to the Great Plains is located within the top $30 \mathrm{~cm}$ of the soil profile (Jackson et al. 1996, Sun et al. 1997), whereas the majority of leafy spurge roots are located below $30 \mathrm{~cm}$ (Figs. $2 \mathrm{~B}-\mathrm{C}$ ). We hypothesize that patchy fertilization, by causing a decrease in leafy spurge root biomass, a shift of roots toward the top of the soil profile, and a concentration of these roots in small fertilized patches close to the surface, could increase the effectiveness of chemical and biological control methods because:

(a) Leafy spurge will have to compete for nutrients in a section of the soil profile dominated by the roots of native plants. Intense root competition in patchy environments has been shown to be a major mechanism for plant displacement (Caldwell et al. 1996).

(b) A reduced root system with a higher proportion of roots concentrated in small fertilized patches close to the soil surface, should increase the susceptibility of leafy spurge to drought, and more importantly improve the ability of both herbicides and insects to reach a substantial part of its root system. 


\section{Literature Cited}

Bonham, C. 1989. Measurements for Terrestrial Vegetation. John Wiley \& Sons. New York.

Bowes, G.G. and A.G. Thomas. 1978 . Longevity of leafy spurge seeds in the soil following various control programs. J. Range Manage. 31: 137-140.

Caldwell, M.M. 1994. Exploiting nutrients in fertile soil microsites. p. 325-347. In: Caldwell M.M. (ed.). Exploration of Environmental Heterogeneity by Plants. Acad. Press Inc., New York.

Caldwell, M.M., J.H. Manwaring, and S.L. Durham. 1996. Species interactions at the level of fine roots in the field: influence of soil nutrient heterogeneity and plant size. Oecologia 106:440-447.

Campbell, B.D, J.P. Grime, and J.M.L. Mackey. 1991. A trade-off between scale and precision in resource foraging. Oecologia 87:532-538.

Cyr, D.R. and J.D. Bewley. 1989. Carbon and nitrogen reserves of leafy spurge (Euphorbia esula) roots as related to overwintering strategy. Physiol. Plant 77: 67-72.

Cyr, D.R. and J.D. Bewley. 1990. Seasonal variation in nitrogen storage reserves in the roots of leafy spurge (Euphorbia esula) and responses to decapitation and defoliation. Physiol. Plant 78: 361-366.

Folks, J.L. 1984. Combination of independent tests. p. 113-122. In: P.R. Krishnaiah and P.K. Sen (ed.). Handbook of Statistics 4. Nonparametric Methods. North Holland, N.Y.

Fransen, B, H. de Kroon, and F. Berendse. 1998. Root morphological plasticity and nutrient acquisition of perennial grass species from habitats of different nutrient availability. Oecologia 115:351-358.
Galitz, D.S. and D.G. Davis. 1983. Leafy spurge physiology and anatomy. North Dakota Farm Res. Bull. 40: 20-26. North Dakota State Univ., Fargo, N.D.

Haynes, R.J., K.C. Cameron, K.M. Goh, and R.R. Sherlock. 1986. Mineral Nitrogen in the Plant-Soil System. Academic Press Inc., London.

Jackson, R.B. and M.M Caldwell. 1996. Integrating resource heterogeneity and plant plasticity: modelling nitrate and phosphate uptake in a patchy soil environment. J. Ecol. 84: 891-903.

Jackson, R.B., J. Canadell, J. R. Ehleringer, H. A. Mooney, O. E. Sala, and E. D. Schulze. 1996. A global analysis of root distributions for terrestrial biomes. Oecologia 108:389-411.

Lajeunesse, S., R., Sheley., R. Lym, D. Cooksey, C. Duncan, J. Lacey, N. Rees, and M. Ferrell. 1995. Leafy spurge biology, ecology, and management. Montana State Univ. Ext. Serv. Circular W-1088 (EB 134). Bozeman, Mont.

Larigauderie, A. and J. H. Richards. 1994. Root proliferation characteristics of seven perennial arid-land grasses in nutrientenriched microsites. Oecologia 99:102-11.

Lym, R.G. and C.G. Messersmith. 1993. Fall cultivation and fertilization to reduce winter hardiness of leafy spurge. Weed Sci. 41: 441446.

Lym, R.G. and R.K. Zollinger. 1995. Integrated management of leafy spurge. North Dakota State Univ. Ext. Service Bull. W-866. North Dakota State Univ., Fargo, N.D.

McIntyre, G.I. and M.V.S. Raju. 1967. Developmental studies on Euphorbia esula: some effects of the nitrogen supply on the growth and development of the seedling. Can. J. Bot. 45: 975-984.
Messersmith, C.G. 1983. The leafy spurge plant. North Dakota Farm Res. Bull. 40: 3-7. North Dakota State Univ., Fargo, N.D.

Raju, M.V.S., T.A. Steeves, and R.T. Coupland. 1963. Developmental studies on Euphorbia esula: morphology of the root system. Can. J. Bot. 41: 579-589.

Regimbal, G.A. and Martin, A.R. 1985. The influence of growth regulators and nitrogen on leafy spruge (Euphorbia esula) control with picloram. Weed Sci. 33: 109-113.

Ryser, P. and H. Lambers. 1995. Root and leaf attributes accounting for the performance of fast- and slow-growing grasses at different nutrient supply. Plant and Soil 170:251-265.

Selleck, G.W., R.T. Coupland, and C. Frankton. 1962. Leafy spruge in Saskatchewan. Ecol. Monog. 32:1-29.

Shipley B. and R.H. Peters. 1990. A test of Tilman model of plant strategies: relative growth rate and biomass partition. The Amer. Nat. 136:139-153.

Sokal, R.R. and F.J. Rohlf. 1969. Biometry. W.H. Freeman \& Company. San Francisco, Calif.

Sun, G, D. P. Coffin, and W. K. Lauenroth. 1997. Comparison of root distributions of species in North American grasslands using GIS. J. Veg. Sci. 8:587-596.

Tilman, D. 1990. Constraints and tradeoffs: toward a predictive theory of competition and succession. Oikos 58:3-15. 


\title{
Rangeland management impacts on soil biological indica- tors in southern Alberta
}

\author{
JOHAN F. DORMAAR AND WALTER D. WILLMS
}

Authors are soil scientist (retired) and range ecologist, Research Centre, Agriculture and Agri-Food Canada, P. O. Box 3000, Lethbridge, Alberta, Canada $T 1 J 4 B 1$.

\begin{abstract}
Quantitative techniques are needed to determine the effects of cultivation and livestock grazing on biological indicators of soils of the Northern Great Plains. Our objective was to determine how various management practices, which were representative of those used since European settlement in the 1880's, affected 3 biological indicators of soil quality. The study was conducted at 3 sites that are representative of the major grassland ecosystems in Canada: a Mixed Prairie site with Stipa comata Trin. \& Rupr. dominant in the Brown (Aridic Haploboroll) Soil Zone, a Mixed Prairie site with S. comata Trin. \& Rupr. and S. viridula Trin. dominant in the Dark Brown (Typic Haploboroll) Soil Zone, and a Fescue Prairie site with Festuca campestris Rydb. dominant in the Black (Udic Haploboroll) Soil Zone. At each site, 6 treatments representing common production practices were imposed and compared with the native community in a randomized complete block design with 4 replicates and a plot size of $3 \times 10$ m. The treatments included: 1) monoculture seeding of 2 grass species; 2) alfalfa (Medicago sativa L. 'Beaver'); 3) continuous spring wheat (Triticum aestivum L. 'Katepwa'); 4) spring wheat and fallow rotation; and 5) abandoned cultivated land. Our hypothesis that mineralizable-N, and phosphatase and dehydrogenase activities would be influenced by cultivation was confirmed by significant changes in these indicators that were detected after only 180 days after treatment establishment. The pool of readily decomposable organic matter was reduced with cultivation and not replenished over the period of the study. The 3 biological indicators were sensitive to not only time following external management changes, but also to seasonal fluctuations. We conclude that soil biological indicators can be used to quantify temporal and botanical changes in diverse ecotypes within the Northern Great Plains.
\end{abstract}

Key Words: steady state, soil transformations, introduced grasses, abandoned land, monoculture

European settlement of the Northern Great Plains had a great effect on the stability of the soil through the imposition of cultivation and grazing by livestock. Southern Alberta is represented by 3 major grassland ecosystems: a Mixed Prairie site with Stipa comata Trin. \& Rupr. dominant in the Brown Soil Zone (around

The help of R. G. Gschaid with establishing the plots and of B. C. Tovell, R Baldwin, and L. Cramer in carrying out the laboratory analyses is gratefully acknowledged. We appreciate T. Entz's help with the statistical analyses.

Lethbridge Research Centre Contribution No. 8379843.

Manuscript accepted 30 May 1999.
Resumen

Técnicas cuantitativas son necesarias para determinar los efectos de la cultivación y el pastoreo del ganado en los indicadores biológicos de suelos de la Grandes Llanuras Norteñas (Northern Great Plains). Nuestro objetivo fue determinar como diferentes prácticas de manejo, que eran representativas de aquellas utilizadas desde el asentamiento de los europeos alrededor de $\mathbf{1 8 8 0}$, afectaron tres indicadores biológicos de la calidad del suelo. El estudio fue conducido en tres lugares que son representativos del ecosistema pastoril más grande de Canadá: un sitio de Pradera Mixta con Stipa comata Trin. y Rupr. dominante en la zona de suelos Marrones (Aridic Haploboroll), otro sitio con Pradera Mixta con $S$. comata Trin. y Rupr. y $S$. viridula Trin. dominante en la zona de suelos Marrones Oscuros (Typic Haploboroll) y por ultimo un sitio con Pradera de Festuca con Festuca campestris Rydb. que es la dominante en la zona de suelos Negros (Udic Haploboroll). En cada sitio se utilizaron seis tratamientos representativos de las prácticas de producción más comunes y se comparó con la comunidad de especies nativas en un diseño de "bloque seleccionado completamente al azar" con cuatro réplicas y un tamaño de parcela de $3 \times 10$ metros. Los tratamientos incluyeron: 1) siembra de monocultivo de dos especies de pastos;2) alfalfa (Medicago sativa $\mathbf{L}$. 'Beaver'); 3) siembra continua de trigo de primavera (Triticum aestivum L. 'Katepwa'); 4) trigo de primavera y rotación con barbecho; 5 ) tierra de cultivo abandonado. Nuestra hipótesis de que el $\mathbf{N}$ mineralizable y que las actividades fosfatasas y dehidrogenasas serían influenciadas por la cultivación fueron confirmadas por cambios significativos en estos indicadores que fueron detectados después de solamente 180 días después del inicio del tratamiento. La materia orgánica de rápida descomposición fue reducida con la cultivación y no fue restablecida durante el período del estudio. Los tres indicadores biológicos fueron sensibles no solamente a los cambios que siguieron a los manejos externos, pero como asi también a las fluctuaciones estacionales. Concluímos que los indicadores biológicos de suelos pueden ser utilizados para cuantificar cambios temporarios y cambios botánicos en diversos ecotipos de la Grandes Llanuras Norteñas (Northern Great Plains).

$2 \%$ organic C), a Mixed Prairie site with S. comata Trin. \& Rupr. and S. viridula Trin. dominant in the Dark Brown Soil Zone (around 4\% organic C), and a Fescue Prairie site with Festuca campestris Rydb. dominant in the Black Soil Zone (around 11\% organic C).

When settlers arrived on the southern Alberta plains, the soils were at a steady state (Jenny 1980) that included fire and free- 
roaming bison. Cultivation, introduction of new grass species, elimination of fire and replacement of bison with confined grazing of cattle, often at intense grazing pressures, interrupted the original steady state.

Biologically and biochemically mediated processes in soils are fundamental to terrestrial ecosystem function and may be early indicators of soil changes. Hence, to identify early warning indicators of ecosystem stress, an understanding of the underlying biological processes is needed (Dick 1994). For example, soil enzyme activity has been shown to have temporal responsiveness (Dormaar et al. 1984) which must be accounted for if used as an indicator of soil quality.

Assuming native grassland communities evolved for optimum utilization of the local environment, an experiment was designed to examine short-term effects of human interruption of the existing rangeland steady state in 3 ecotypes in the Northern Great Plains. We hypothesized that biological activities including mineralizable-N and enzyme activities would be good indicators of steady state interruption, and thus also be good indicators of changes in rangeland soil quality.

\section{Materials and Methods}

\section{Site Description}

The study was conducted at 3 sites, widely separated geographically, and representative of major ecotypes of the Northern Great Plains (Table 1). One site was at the Agriculture and Agri-Food Canada substation at Onefour $\left(49^{\circ} 07^{\prime} \mathrm{N}\right.$, $110^{\circ} 29^{\prime} \mathrm{W}$ ) and represented the StipaBouteloua faciation of the Mixed Prairie. The second site was at the Animal Diseases Research Institute (ADRI) near Lethbridge $\left(49^{\circ} 43^{\prime} \mathrm{N}, 112^{\circ} 57^{\prime} \mathrm{W}\right)$ and represented the Stipa-Bouteloua-Agropyron faciation of the Mixed Prairie. A third site was at the Agriculture and Agri-Food Canada substation in the Porcupine Hills west of Stavely $\left(50^{\circ} 12^{\prime} \mathrm{N}, 113^{\circ} 57^{\prime} \mathrm{W}\right)$ and represented Fescue Prairie dominated by rough fescue (Festuca campestris). The vegetation at these sites has been described by Moss and Campbell (1947) and Coupland (1961).

\section{Methods}

At each site, 6 treatments representing common production practices were imposed and compared with the native community in a randomized complete block design with 4 replicates and plot sizes $3 \times 10 \mathrm{~m}$. The treatments included 1) monoculture seeding of 2 grass species; 2) alfalfa (Medicago sativa L. 'Beaver'); 3) continuous spring wheat (Triticum aes tivum L. 'Katepwa'); 4) spring wheat and fallow in rotation; and 5) abandoned cultivated land. On the 2 mixed prairie sites (Onefour and Lethbridge), the introduced grass treatments were crested wheatgrass (Agropyron cristatum (L.) Gaertn.) and Russian wildrye (Elymus junceus Fisch.). On the fescue prairie, smooth bromegrass (Bromus inermis Leyss.) and orchard grass (Dactylis glomerata L.) were sown. All plots were established in spring (Table 1) by cultivating and seeding, or abandoning a previously uncultivated native plant community. The native treatment was left intact and undisturbed during plot preparation. The abandoned plot was cultivated several times during the first summer and plants that emerged from live tillers were removed until the second year. All seedings were using $15-\mathrm{cm}$ row spacing. The Stipa-Agropyron-Bouteloua and Festuca campestris sites were prepared and established in spring 1993 and the StipaBouteloua site was established in spring 1994. Each site was enclosed with a 4strand barbed-wire fence that excluded livestock.

Soil samples were taken through the centre of the plots to eliminate edge effect in fall and spring over a 3-year period, beginning in the fall of 1993, at the StipaAgropyron-Bouteloua and Festuca campestris sites, and over a 2-year period, beginning in the fall of 1994, at the StipaBouteloua site (Table 1). Three subsamples from the Ah (=A1) soil horizon were taken by spade, composited, and handsieved in the field through a 2-mm screen. The samples were stored in sealed, double polyethylene bags at $4^{\circ} \mathrm{C}$.
All analyses were made using moist soil and carried out within 3 weeks of arrival at the laboratory. Moisture content was determined gravimetrically. Mineralizable-N, as an index of biological $\mathrm{N}$ availability, was determined as described by Keeney (1982). Dehydrogenase activity, a common enzymatic activity to estimate microbial activity, was determined at $\mathrm{pH} 7.6$ on fresh, moist soil by measuring the triphenylformazan (formazan) produced by reduction of 2,3,5-triphenyltetrazolium chloride when soil was incubated with 2-amino-2(hydroxymethyl)propane-1:3-diol buffer $(0.5 \mathrm{M})$ at $30^{\circ} \mathrm{C}$ for 5 hours (Ross 1971). Phosphatase activity, an indicator of capability to cleave phosphate esters, was determined at $\mathrm{pH} 6.5$ on fresh, moist soil by measuring p-nitrophenol produced when soil was incubated with buffered disodium $p$-nitrophenyl phosphate tetrahydrate solution $(0.115 \mathrm{M})$ and toluene at $37^{\circ} \mathrm{C}$ for 1 hour (Tabatabai and Bremner 1969).

\section{Statistical Analyses}

Each variable was analysed in a whole model as an unbalanced 3 (sites) $x 7$ (treatments) x 2 (seasons) x 2 or 3 (years) $\mathrm{x} 4$ (replicates) split-split-split plot design (Table 2) using the GLM Procedure of SAS (1989). The potential bias resulting from repeated measurements over years was alleviated using the Box Correction Procedure (Milliken and Johnson 1984). The data were unbalanced because there were only 2 years for the Stipa-Bouteloua site and the grass species were combined as 1 treatment to yield $2 \mathrm{x}$ the plot number for the new treatment. This was done to account for the differences in species among sites. The variables were highly responsive to the factors tested and meaningful interpretation required a more detailed examination of the data. This was accomplished by analysing the data by individual site, and the grass species as individual treatments, as a 7 (treatments) $\mathrm{x}$ 2 (seasons) x 2 or 3 (years) x 4 (replicates) split-split plot design. Further analyses consisted of evaluating only the first year effects in a 7 (treatments) x 4 (replicates) design for each season. The yearly trend of each index was also evaluated, for each

Table 1. Study site descriptions.

\begin{tabular}{|c|c|c|c|c|c|c|c|c|c|c|c|}
\hline \multirow[t]{3}{*}{ Location } & \multirow[t]{3}{*}{ Soil Zone } & \multicolumn{2}{|l|}{ Soil } & \multirow{2}{*}{$\begin{array}{c}\text { Average } \\
\text { Precipitation }\end{array}$} & \multirow[t]{3}{*}{ Started } & \multicolumn{6}{|c|}{ Soil Sampling Dates } \\
\hline & & Canada & U.S. & & & 1993 & & 1994 & & 1995 & 1996 \\
\hline & & (Chernozemic) & (Haploboroll) & $(\mathrm{mm})$ & & & & & & & \\
\hline Onefour & Brown & Orthic Brown & Aridic & 310 & 6 Apr. 1994 & & & 1 Nov. & $20 \mathrm{Apr}$. & 28 Sep. & 22 Apr. \\
\hline ADRI & Dark Brown & Orthic Dark Brown & Typic & 420 & 1 Apr. 1993 & 29 Sep. & 21 Apr. & 10 Oct. & 8 Apr. & 11 Oct. & 1 May \\
\hline Stavely & Black & Orthic Black & Udic & 550 & 13 Apr. 1993 & 3 Oct. & 22 Apr. & 19 Sep. & 17 May & 14 Sep. & 6 Jun. \\
\hline
\end{tabular}


Table 2. Analyses of variance for the whole model and by site of $\mathbf{4}$ variables to examine the influence of modified plant communities, site, season, and year on selected soil parameters.

\begin{tabular}{|c|c|c|c|c|c|}
\hline \multirow[t]{2}{*}{ Source of variation } & \multirow[t]{2}{*}{ Df } & & \multicolumn{3}{|c|}{ Probabilities/Means } \\
\hline & & Moisture & Mineralizable- $^{1}$ & $\begin{array}{l}\text { Dehydrogenase } \\
\text { Activity }^{2}\end{array}$ & $\begin{array}{l}\text { Phosphatase } \\
\text { Activity }^{3}\end{array}$ \\
\hline $\begin{array}{l}\text { Whole model } \\
\text { Site }\end{array}$ & & (\%) & -Means-- & & \\
\hline Stipa-Bouteloua & & 12 & 43 & 63 & 867 \\
\hline Stipa-Agropyron-Bouteloua & & 16 & 75 & 103 & 566 \\
\hline $\begin{array}{l}\text { Rough Fescue Prairie } \\
\text { Partial Models (by site) }\end{array}$ & & 40 & 205 & 198 & 2914 \\
\hline \multicolumn{6}{|l|}{ Stipa-Bouteloua $^{5}$} \\
\hline Treatment $(\mathrm{T})$ & 6 & $<0.01$ & $<0.01$ & $<0.01$ & $<0.01$ \\
\hline $\mathrm{R} \times \mathrm{T}$ (Error 1) & 21 & & & & \\
\hline Season $(\mathrm{Se})$ & 1 & $<0.01$ & 0.02 & 0.10 & $<0.01$ \\
\hline $\mathrm{T} \times \mathrm{Se}$ & 6 & $<0.01$ & 0.02 & $<0.01$ & 0.06 \\
\hline $\mathrm{R} \times \mathrm{T} \times \mathrm{Se}$ (Error 2) & 21 & & & & \\
\hline Year $(Y)$ & 1 & $<0.01$ & 0.10 & $<0.01$ & $<0.01$ \\
\hline Se x Y & 1 & $<0.01$ & $<0.01$ & $<0.01$ & $<0.01$ \\
\hline $\mathrm{T} \times \mathrm{Y}$ & 6 & $<0.01$ & $<0.01$ & $<0.01$ & 0.22 \\
\hline T x Se x Y & 6 & $<0.01$ & $<0.01$ & $<0.01$ & 0.02 \\
\hline R x T x Se x Y (Error 3) & 111 & & & & \\
\hline Year & $\cdots$ & & ----Means---- & & \\
\hline 1994/95 & & 15 & 42 & 68 & 914 \\
\hline 1995/96 & & 12 & 43 & 63 & 867 \\
\hline \multicolumn{6}{|l|}{ Stipa-Agropyron-Bouteloua ${ }^{6}$} \\
\hline Treatment $(\mathrm{T})$ & 6 & $<0.01$ & $<0.01$ & $<0.01$ & $<0.01$ \\
\hline $\mathrm{R} \times \mathrm{T}$ (Error 1) & 21 & & & & \\
\hline Season (Se) & 1 & $<0.01$ & 0.02 & $<0.01$ & 0.14 \\
\hline $\mathrm{T} \times \mathrm{Se}$ & 6 & $<0.01$ & $<0.01$ & $<0.01$ & $<0.01$ \\
\hline $\mathrm{R} \times \mathrm{T} \times \mathrm{Se}$ (Error 2) & 21 & & & & \\
\hline Year $(\mathrm{Y})$ & 2 & $<0.01$ & $<0.01$ & $<0.01$ & $<0.01$ \\
\hline Se $x$ Y & 2 & $<0.01$ & $<0.01$ & $<0.01$ & $<0.01$ \\
\hline $\mathrm{T} \times \mathrm{Y}$ & 12 & $<0.01$ & $<0.01$ & $<0.01$ & $<0.01$ \\
\hline $\mathrm{T} \times \mathrm{Se} \times \mathrm{Y}$ & 12 & $<0.01$ & $<0.01$ & $<0.01$ & $<0.01$ \\
\hline R x T x Se x Y (Error 3) & 167 & & & & \\
\hline \multicolumn{6}{|l|}{$\begin{array}{l}\text { Year } \\
1993 / 94\end{array}$} \\
\hline 1993/94 & & 19 & 95 & 68 & 719 \\
\hline $1994 / 95$ & & 16 & 75 & 103 & 566 \\
\hline $1995 / 96 \ldots 7$ & & 18 & 83 & 106 & 466 \\
\hline \\
\hline Treatment $(\mathrm{T})$ & 6 & $<0.01$ & $<0.01$ & $<0.01$ & $<0.01$ \\
\hline $\mathrm{R} \times \mathrm{T}$ (Error 1) & 21 & & & & \\
\hline Season (Se) & 1 & $<0.01$ & $<0.01$ & $<0.01$ & 0.03 \\
\hline $\mathrm{T} \times \mathrm{Se}$ & 6 & $<0.01$ & $<0.01$ & $<0.01$ & $<0.01$ \\
\hline $\mathrm{R} \times \mathrm{T} \times \mathrm{Se}$ (Error 2) & 21 & & & & \\
\hline Year $(Y)$ & 2 & $<0.01$ & $<0.01$ & $<0.01$ & $<0.01$ \\
\hline Se $x$ Y & 2 & $<0.01$ & $<0.01$ & $<0.01$ & $<0.01$ \\
\hline $\mathrm{T} \times \mathrm{Y}$ & 12 & $<0.01$ & $<0.01$ & $<0.01$ & $<0.01$ \\
\hline T x Se x Y & 12 & $<0.01$ & $<0.01$ & $<0.01$ & $<0.01$ \\
\hline R x T x Se x Y (Error 3) & 167 & & & & \\
\hline \multicolumn{6}{|l|}{ Year- } \\
\hline 1993/94 & & 50 & 306 & 189 & 4933 \\
\hline 1994/95 & & 40 & 205 & 198 & 2914 \\
\hline $1995 / 96$ & & 40 & 197 & 180 & 2728 \\
\hline 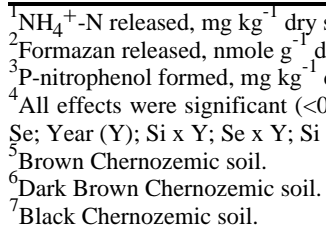 & $\begin{array}{l}\text { soil h}^{-1} \\
\text { dry soil } \\
\text { dry soi } \\
0.01 \text { ) fo } \\
\text { x T x Y }\end{array}$ & $\begin{array}{l}\text { variable: } \\
\text { Se x Y; Si }\end{array}$ & $\begin{array}{l}(\mathrm{Si}) \text {; Treatment }(\mathrm{T} \\
\text { x Se x Y. }\end{array}$ & $\mathrm{T}$; Season (Se); $\mathrm{S}$ & x Se; Si x T \\
\hline
\end{tabular}

site, as either the difference between 2 years with a t-test (Stipa-Bouteloua site) or with simple linear regression over 3 years (Stipa-Agropyron-Bouteloua and evaluated by subtracting the native soil (control) value for each indicator. This was done to remove the effect of environ-
Festuca campestris sites). The trends were ment at the time of sampling by assuming its effect on the control was the same as on the treatments (Table 4). Trends were thus established for each season, treatment, and replicate that were then evaluated by analysis of variance to test for the effect of season. Since the season by treatment interaction was significant $(\mathrm{P}<0.05)$, in all but one case, (phosphatase activity on the Stipa-Bouteloua site), the data were reported by season and treatment. Mean separation was achieved using single degree of freedom contrasts (Steel and Torrie 1980).

\section{Results}

The indices of soil quality selected, i.e., mineralizable- $\mathrm{N}$, and dehydrogenase and phosphatase activities, were highly responsive $(\mathrm{P}<0.01)$ to the agronomic treatments and were influenced $(\mathrm{P}<0.01)$ by site, season and year (Table 2). The main effects all influenced $(P<0.01)$ one another necessitating a more detailed examination to discern constituent response (Tables 3 and 4). The indices of soil quality tended to increase across sites with Stipa-Bouteloua < Stipa-AgropyronBouteloua < Festuca campestris. This response corresponded to increased soil moisture at the time of sampling (Table 2). Only phosphatase activity was lower on the Stipa-Agropyron-Bouteloua site than on the Stipa-Bouteloua site (Table 2).

The unadjusted (with the control) indices of soil quality tended to decrease with years since cultivation (Table 2). These means include the control (native prairie), so the trend describing the effect of years since cultivation was partially obscured by this analysis.

In the first year, cultivation and seeding affected the indices of soil quality ( $\mathrm{P}<$ 0.05 ) in both fall and spring on each site (Table 3). The mineralizable-N and dehydrogenase activity were reduced by all treatments in both seasons on the StipaBouteloua site and in spring only on the Stipa-Agropyron-Bouteloua and Festuca campestris sites (Table 3); however, both indices increased $(\mathrm{P}<0.05)$ in response to treatment in fall on the Stipa-AgropyronBouteloua and Festuca campestris sites. Phosphatase activity tended to follow a similar pattern of response as the biological index and dehydrogenase activity, but with 1 exception in fall where the response to cultivation was less clear on the StipaBouleloua site. Among the treatments in the first year, grass species tended to have lower mineralizable-N, and lower or simi- 
Table 3. The influence of cultivation and modified plant communities on selected soil parameters in the year after establishment.

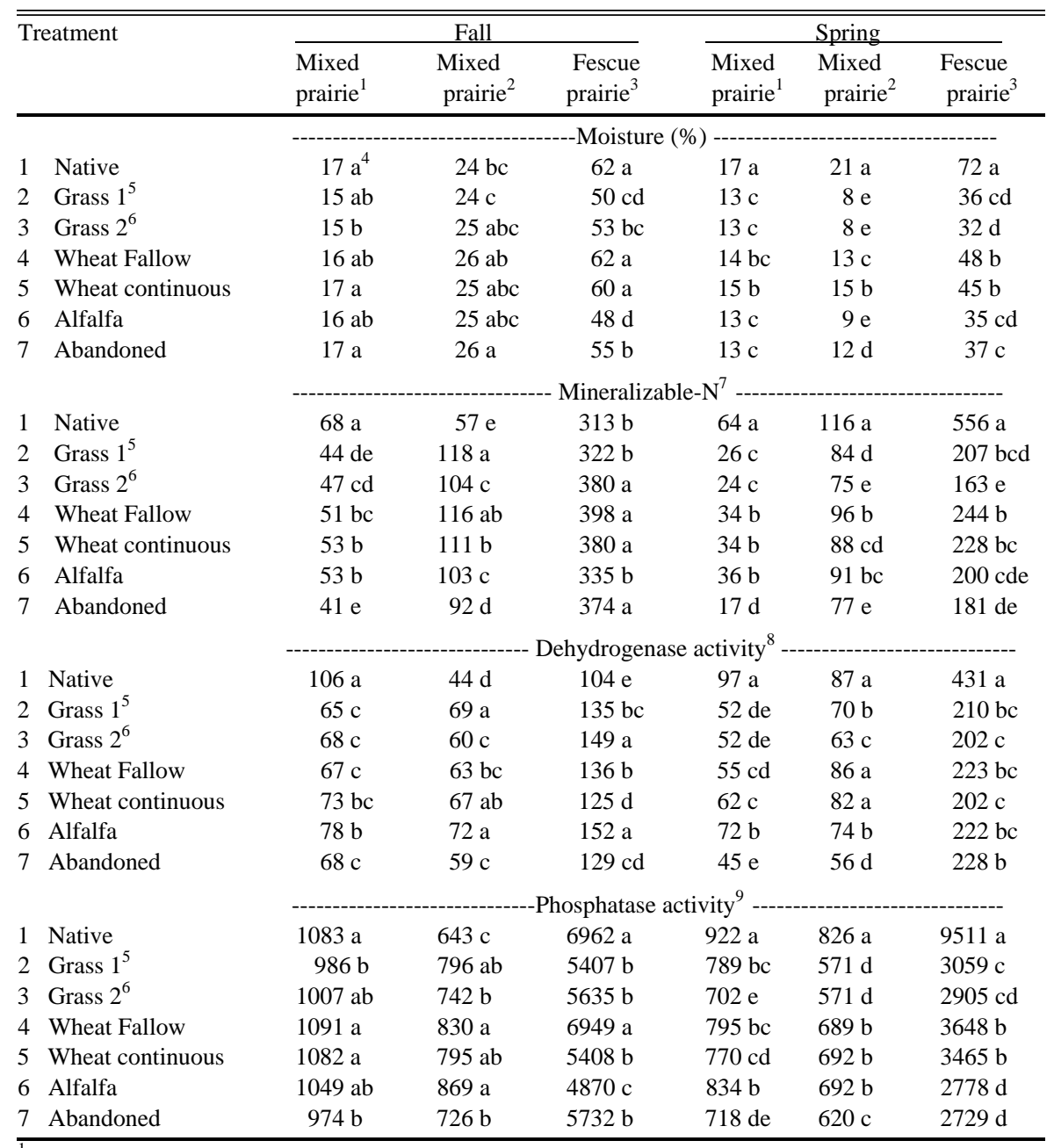

${ }^{1}$ Stipa-Bouteloua, Brown Chernozemic soil.

${ }^{2}$ Stipa-Agropyron-Bouteloua, Dark Brown Chernozemic soil.

${ }^{3}$ Festuca campestris, Black Chernozemic soil.

${ }^{4}$ Means having the same letter within a subset of the column do not differ significantly $\mathrm{P}>0.05$.

${ }^{5}$ Grass species is crested wheatgrass in the mixed prairie and smooth brome in the fescue prairie.

${ }^{6}$ Grass species is Russian wildrye in the mixed prairie and orchard grass in the fescue prairie.

${ }_{8}^{7} \mathrm{NH}_{4}{ }^{+}$-N released, $\mathrm{mg} \mathrm{kg}^{-1}$ dry soil $\mathrm{h}^{-1}$.

${ }^{8}$ Formazan released, nmole $\mathrm{g}^{-1}$ dry soil $\mathrm{h}^{-1}$

${ }^{9}$ P-nitrophenol formed, $\mathrm{mg} \mathrm{kg}^{-1}$ dry soil ${ }^{-1}$.

lar dehydrogenase and phosphatase activities compared to wheat (Table 3 ). The 2 wheat treatments in the first year were identical and the differences $(\mathrm{P}<0.05)$ detected between them (Table 3 ) are an anomaly likely produced by sampling.

Trends in the indices of soil quality over years since cultivation and seeding (Table 4) were, with a few exceptions, affected (P $<0.05)$ by treatment, season, and their interaction. On the Stipa-Bouteloua site, the trend of dehydrogenase activity was not $(P>0.05)$ influenced by either treatment or season while phosphatase activity was not $(P>0.05)$ influenced by treatment or the interaction of treatment with season. On the Stipa-Agropyron-Bouteloua site, only dehydrogenase activity was not $(\mathrm{P}>$ 0.05 ) influenced by season.

Over years since cultivation and seeding, mineralizable- $\mathrm{N}$ tended to decline in fall and increase in spring (Table 4). The treatment response, and differences between season, became greater from the Stipa-Bouteloua to the Festuca campestris sites. Dehydrogenase activity increased in both spring and fall in a similar manner $(\mathrm{P}$ $<0.05)$ across treatments on the StipaBouteloua site. In the Stipa-AgropyronBouteloua site, dehydrogenase activity was mostly unaffected by years since cultivation and seeding while on the Festuca campestris site, dehydrogenous activity increased $(\mathrm{P}<0.05)$ over all treatments in spring and tended to decrease in fall except where orchard grass was seeded (Table 4). In the fall, phosphatase activity decreased over years since cultivation and seeding on both the Stipa-Bouteloua and Stipa-Agropyron-Bouteloua sites but increased on the Festuca campestris site. In spring, phosphatase activity increased on the Festuca campestris site, but remained mostly constant on the other 2 sites (Table 4).

\section{Discussion}

\section{Initial effect of cultivation}

Cultivation and seeding had a dramatic effect on the indices of soil quality as measured by mineralizable- $\mathrm{N}$, dehydrogenase activity, and phosphatase activity. These effects were mediated by site, season and treatment and influenced by time after cultivation and seeding. Since the first time measurement was made only 180 days after cultivation and seeding, we speculate that cultivation stimulated a rapid release of organic compounds through microbial decomposition of existing soil organic matter that was readily decomposed and was not replenished under the newly established cultivated species.

\section{How are the indices related to soil organic matter and soil quality?}

Site differences appear to be related to the decomposable nature of the organic matter. That is, the Ah horizon of Brown Chernozemic soils contained considerably more organic matter that was readily decomposable (Dormaar 1975) and less resistant to thermal decomposition (Lutwick and Dormaar 1976) than that under Black Chernozemic soils. Up to $39 \%$ of the organic matter of Brown Chernozemic soils was still in an undecomposed form compared with $5 \%$ in Black Chernozemic soils (Dormaar 1977). Comminution of root mass is significantly greater under Mixed Prairie than under the fescue prairie (Dormaar and Willms 1993).

It is clear that the variables of the 3 sites are different even in response to the treatments. For the 4 comparisons of the first 2 years, the phosphatase activities were consistently lower for the Dark Brown than for the Brown Chernozemic soil. Conversely, under growth chamber conditions phosphatase activity was Brown<Dark Brown<Black Chernozemic soils (Dormaar 1988). Although the rea- 
Table 4. Trends of selected soil quality variables in 3 plant communities over a 2 or 3 year period since cultivation and reseeding, or abandonment, in both fall and spring after adjustment for the composition in native soil.

\begin{tabular}{|c|c|c|c|c|c|c|c|}
\hline & & $\begin{array}{c}\text { Crested } \\
\text { wheat- } \\
\text { grass }\end{array}$ & $\begin{array}{l}\text { Russian } \\
\text { wild rye }\end{array}$ & $\begin{array}{l}\text { Wheat- } \\
\text { fallow }\end{array}$ & $\begin{array}{c}\text { Continuous } \\
\text { wheat }\end{array}$ & Is Alfalfa & Abandoned \\
\hline \multicolumn{8}{|l|}{ Stipa-Bouteloua $^{1}$} \\
\hline \multirow[t]{2}{*}{ Soil Moisture (\%) } & Fall & -0.25 & 0.5 & $5.50 *^{3}$ & $4.25^{*}$ & 0.75 & 2.00 \\
\hline & Spring & 1.5 & 1.25 & 0 & 0.25 & 3.25 & 1.25 \\
\hline \multirow[t]{2}{*}{ Mineralizable- $\mathrm{N}^{4}$} & Fall & 3 & -0.2 & -1.2 & -7 & -7.2 & 3.5 \\
\hline & Spring & $23.0^{*}$ & $27.0^{*}$ & 11.8 & 13 & $25.8^{*}$ & $31.5^{*}$ \\
\hline \multirow[t]{2}{*}{ Dehydrogenase $^{5}$} & Fall & $29.0^{*}$ & $18.5^{*}$ & $42.5^{*}$ & $35.75^{*}$ & 19.5 & $28.0^{*}$ \\
\hline & Spring & $27.0^{*}$ & $30.8^{*}$ & $22.5^{*}$ & 17 & $28.5^{*}$ & $30.0^{*}$ \\
\hline \multirow[t]{2}{*}{ Phosphatase $^{6}$} & Fall & $-55^{*}$ & $-106^{*}$ & $-137 *$ & -105 & -19 & -68 \\
\hline & Spring & 29 & 70 & 22 & 67 & 50 & 19 \\
\hline \multicolumn{8}{|c|}{ Stipa-Agropyron-Bouteloua ${ }^{2}$} \\
\hline \multirow[t]{2}{*}{ Soil Moisture (\%) } & Fall & -1.88 & $-3.38^{*}$ & -2.38 & $-3.25 *$ & $-3.75^{*}$ & $-3.25^{*}$ \\
\hline & Spring & 0.12 & 0.88 & 0.5 & 0 & 0.62 & 0.5 \\
\hline \multirow[t]{2}{*}{ Mineralizable-N } & Fall & $-31.1^{*}$ & $-21.6^{*}$ & $-34.4^{*}$ & $-35.6^{*}$ & $-25.8^{*}$ & -23.2 \\
\hline & Spring & 7.9 & $9.9 *$ & -4.2 & 3.5 & $10.0^{*}$ & $13.6^{*}$ \\
\hline \multirow[t]{2}{*}{ Dehydrogenase } & Fall & 3.6 & -1.2 & 7.5 & -5.5 & 1.4 & 3.2 \\
\hline & Spring & 7.8 & 0 & -8.1 & -6.5 & 5.8 & 13.1 \\
\hline \multirow[t]{2}{*}{ Phosphatase } & Fall & $-191 *$ & $-134 *$ & $-152^{*}$ & $-184^{*}$ & $-160 *$ & $-118^{*}$ \\
\hline & \multicolumn{7}{|c|}{ Fescue Prairie $^{2}$} \\
\hline & & $\begin{array}{c}\text { Orchard } \\
\text { Grass }\end{array}$ & $\begin{array}{l}\text { Smooth } \\
\text { Brome }\end{array}$ & & & & \\
\hline \multirow[t]{2}{*}{ Soil Moisture (\%) } & Fall & 1.62 & -4 & $-5.12^{*}$ & -2.5 & 2 & -3 \\
\hline & Spring & $13.00 *$ & $11.50 *$ & 3.12 & 4.38 & 8.88 & 4.62 \\
\hline \multirow[t]{2}{*}{ Mineralizable-N } & Fall & $-60.0^{*}$ & $-132.0^{*}$ & $-129.4^{*}$ & $-93.1^{*}$ & $-101.0^{*}$ & $-136.6^{*}$ \\
\hline & Spring & $121.9^{*}$ & $103.0^{*}$ & $56.8^{*}$ & $80.0^{*}$ & $73.4^{*}$ & $87.6^{*}$ \\
\hline \multirow[t]{2}{*}{ Dehydrogenase } & Fall & $33.6^{*}$ & -15 & $-25.6^{*}$ & 10.1 & -25.4 & -7.4 \\
\hline & Spring & $134.0^{*}$ & $123.2^{*}$ & $121.9^{*}$ & $146.1^{*}$ & $128.6^{*}$ & $151.4^{*}$ \\
\hline \multirow[t]{2}{*}{ Phosphate } & Fall & $69^{*}$ & 342 & -235 & $614^{*}$ & $809^{*}$ & $258^{*}$ \\
\hline & Spring & $2176^{*}$ & $1949 *$ & $1655^{*}$ & $1661 *$ & $1945^{*}$ & $1679 *$ \\
\hline
\end{tabular}

${ }^{\mathrm{T}}$ Mean differences of adjusted values between the first and second years after establishment of qualitative constituents, $\mathrm{n}=8$.

${ }^{2}$ Coefficients of linear regression equations of adjusted values over 3 years $(n=12)$; average change of the coefficients over the 3 years.

${ }^{3}$ Asterisk denotes a significant $(\mathrm{P}>0.05)$ mean difference or coefficient $(\mathrm{n}=12)$.

${ }_{5}^{4} \mathrm{NH}_{4}{ }^{+}-\mathrm{N}$ released, $\mathrm{mg} \mathrm{kg}^{-1}$ dry soil $\mathrm{h}^{-1}$.

${ }^{5}$ Dehydrogenase activity: Formazan released, nmole $\mathrm{g}^{-1}$ dry soil $\mathrm{h}^{-1}$.

${ }^{6}$ Phosphatase activity: P-nitrophenol formed, $\mathrm{mg} \mathrm{kg}^{-1}$ dry soil $\mathrm{h}^{-1}$.

sons for this are not fully understood, a tentative explanation, for the spring differences at least, in the field, can be offered. If the ratio of soil organic carbon (C)/ $\mathrm{NaOH}$-extractable organic phosphorus (P) increases, it means more inorganic $\mathrm{P}$ bound to the soil organic matter complex has been released by the phosphatases present in the soil (Dormaar 1972, Dormaar et al. 1984). This leads to decreased levels of phosphatase activity and increased levels of available inorganic $\mathrm{P}$. This available inorganic $\mathrm{P}$, however, is immediately being taken up by the roots as the plant actively starts to grow again in the spring (Dormaar 1972). When the spring 1996 samples were obtained for this study, other samples were collected for a 1-time, early comparison of the various treatments (unpublished data). The ratios of total organic soil $\mathrm{C}$ over $\mathrm{NaOH}$-extractable organic $\mathrm{P}$ for the average of all 28 samples ( 7 treatments $\times 4$ replicates) per site are 248, 425, and 156 for the Brown, Dark Brown, and Black Chernozemic soils, respectively. Obviously, timing, i.e., attempting to sample at equivalent biological activity stages, would be desirable; however, weather conditions generally do not permit this. In addition, there are numerous other factors, such as soil moisture, depth of Ah horizon and chemical properties, that influence soil phosphatase activities (Speir and Ross 1978).

On the whole, with some exceptions at the Stipa-Agropyron-Bouteloua site, once native prairie has been disturbed, in spite of replacement with introduced grass species, biological activity in the soil has decreased in the first 2 or 3 years. Time will tell if the various treatments will be able to rebuild biological activity to the level of native prairie. This will depend on root mass and plant contributions to the rhizosphere ecosystem. The rhizosphere of the plant provides a surface for microbiological colonization which uses root exudates as an energy source. A major problem is to quantify the amounts of photosynthate that enters the rhizosphere and to identify the composition of root exudates. Only 1 study, and that in a growth chamber, quantified the amounts of photosynthate that enters the rhizosphere of 1 of the native grass species involved, i.e., Bouteloua gracilis (H.B.K.) Lag. (Dormaar and Sauerbeck 1983). Attempts have also been made to determine the impact of the interaction of root systems of 4 different plant species on the quantities and composition of root exudates. Dormaar (1988) and McKenzie et al. (1995) concluded that the properties of rhizosphere soil are system specific, that is, rhizosphere changes are a function of plant species, soil type, and time.

Dick (1994) noted that the primary value of measuring soil enzyme activities may not be to estimate biological activity per se, but rather as an integrative indicator of a change in the biology and biochemistry of soil. This may be due to the external management, such as monoculture of various crops or abandonment, or to environmental factors, such as location and time of the year. The study presented indeed has shown that the 3 biological activity parameters selected were quite sensitive to not only time following external management, but also to seasonal fluctuations. Comparing between sites does not seem realistic, since it is difficult to have each site at the same climatic conditions at the time of sampling. Comparing within sites supports the conclusions on a field scale that were obtained under growth chamber conditions by Dormaar (1988) and McKenzie et al. (1995). Biological activity parameters can be used as soil quality indicators on a routine basis to follow within-site temporal and botanical changes.

\section{Literature Cited}

Coupland, R.T. 1961. A reconsideration of grassland classification in the northern Great Plains of North America. J. Ecol. 49:135-167.

Dick, R.P. 1994. Soil enzyme activities as indicators of soil quality, p. 107-124. In: J.W. Doran, D.C. Coleman, D.F. Bezdicek, and 
B.A. Stewart (eds.), Defining soil quality for a sustainable environment. Soil Sci. Soc. Amer. Spec. Publ. No. 35.

Dormaar, J.F. 1972. Seasonal pattern of soil organic phosphorus. Can. J. Soil Sci. 52:107-112.

Dormaar, J.F. 1975. Susceptibility of organic matter of Chernozemic Ah horizons to biological decomposition. Can. J. Soil Sci. 55:473-480.

Dormaar, J.F. 1977. La fraction humine dans les horizons Ah de Chernozems modaux et lessives. Science du Sol (1977):69-80.

Dormaar, J.F. 1988. Effect of plant roots on chemical and biochemical properties of surrounding discrete soil zones. Can. J. Soil Sci. 68:233-242.

Dormaar, J.F. and D.R. Sauerbeck. 1983. Seasonal effects on photoassimilated carbon14 in the root system of blue grama and associated soil organic matter. Soil Biol. Biochem. 15:475-479.

Dormaar, J.F. and W.D. Willms. 1993. Decomposition of blue grama and rough fescue roots in prairie soils. J. Range Manage. 46:207-213.
Dormaar, J.F., A. Johnston, and S. Smoliak. 1984. Seasonal changes in carbon content, and dehydrogenase, phosphatase, and urease activities in mixed prairie and fescue grassland Ah horizons. J. Range Manage. 37:31-35.

Jenny, H. 1980. The soil resource. SpringerVerlag, New York, N.Y.

Keeney, D.R. 1982. Nitrogen-availability indices. In: A.L.Page (ed.), Methods for soil analysis. Part 2. Chemical and microbiological properties. Agron. 9:711-733. Amer. Soc. Agron., Madison, Wis.

Lutwick, L.E. and J.F. Dormaar. 1976. Relationships between the nature of soil organic matter and root lignins of grasses in a zonal sequence of Chernozemic soils. Can. J. Soil Sci. 56:363-371.

McKenzie, R.H., J.F. Dormaar, G.B. Schaalje, and J.W.B. Stewart. 1995. Chemical and biochemical changes in the rhizospheres of wheat and canola. Can. J. Soil Sci. 75: 439-447.

Milliken, G.A. and D.E. Johnson. 1984. Analysis of messy data. Vol. 1: Designed experiments. van Norstrand Reinhold Co., New York.
Moss, E.G. and J.A. Campbell. 1947. The fescue grassland of Alberta. Can. J. Res. C25:209-227.

Ross, D.J. 1971. Some factors influencing the estimation of dehydrogenase activities of some soils under pasture. Soil Biol. Biochem. 3:97-110.

SAS Institute Inc. 1989. SAS/STAT users guide, Version 6, 4th ed., Vol. 2. SAS Institute Inc., Cary, N.C.

Speir, T.W. and D.J. Ross. 1978. Soil phosphatase and sulphatase, p.197-250. In: R.G. Burns (ed.), Soil enzymes. Academic Press Inc. (London) Ltd., England.

Steel, R.G.D. and J.H. Torrie. 1980. Principles and procedures of statistics: A biometrical approach. McGraw-Hill Book Co., New York.

Tabatabai, M.A. and J.M. Bremner. 1969. Use of $p$-nitrophenyl phosphate for assay of soil phosphatase activity. Soil Biol. Biochem. 1:301-307. 


\title{
Broom snakeweed establishment following fire and herbi- cide treatments
}

\author{
K. C. MCDANIEL, D. B. CARROLL, AND C. R. HART
}

Authors are professor and former graduate research assistants, Department of Animal and Range Sciences, New Mexico State University, Las Cruces, N.M 88003 .

\begin{abstract}
Broom snakeweed (Gutierrezia sarothrae [Pursh] Britt \& Rusby) propagation was monitored from 1990 through 1998 following burning and herbicide control practices conducted on blue grama (Bouteloua gracilis [H. B. K. Lag.]) grasslands near Corona, N.M. Broom snakeweed usually germinated in April, May, or June (83\% of 394 total) and mostly in 1991 and 1992 (81\% of total) when spring moisture was sufficient. The majority of broom snakeweed seedlings (52\% of total) emerged the first or second year after summer burning, especially in areas where grass yield and cover declined and bare ground exposure increased as a result of intense fires. Spring fires caused less damage to blue grama than summer fires, and the number of broom snakeweed seedlings produced (18\% of total) was similar to non-treated rangeland ( $22 \%$ of total), but lower than numbers on areas burned in the summer. Grass yield and cover increased within a year of herbicide spraying and treated plots had significantly $(P<0.05)$ fewer broom snakeweed seedlings $(8 \%$ of total $)$ than burned and non-treated areas.
\end{abstract}

Key Words: Shortgrass prairie, germination, emergence, prescribed burning, picloram

The historical burning frequency on New Mexico's blue grama grasslands is unknown but Wright and Bailey (1982) speculate wildfires to have periodically occurred during periods of drought and probably at 15 to 25 year intervals. Today, wildfires on these shortgrass rangelands are usually started by accident (railroad box fires, downed power lines, etc.) rather than by natural causes (McDaniel et al. 1989). Prescribed burns are uncommon but occasionally landowners will conduct planned fires to remove broom snakeweed and other undesirable weeds and brush.

When burning blue grama grasslands, the majority of mature broom snakeweed can be eliminated provided fuel and weather conditions are suitable to produce heat of sufficient intensity to destroy the entire canopy (McDaniel et al. 1997). Extremely hot fires, however, often damage blue grama and other perennial plants, thereby creating micro-sites potentially favorable for

Research was supported by the New Mexico Agricultural Experiment Station and funded by a State of New Mexico legislative appropriation and USDAÑCSRS Special Grant for broom snakeweed research.

The authors wish to thank Mr. Gene Parker and the staff of the Livestock and Range Research Center for their assistance in this study. Funding was provided by special grants for broom snakeweed research through the Agricultural Experiment Station, Las Cruces, N.M.

Manuscript accepted 5 July 1999

\section{Resumen}

De 1990 a 1998 se monitoreo la propagación "Broom snakeweed" (Gutierrezia sarothrae [Pursh] Britt \& Rusby) después de aplicar quema y herbicidas como practicas de control en un pastizal de "Blue grama" (Bouteloua gracilis [H.B.K. Lag]) situado cerca de Corona, N.M. El "Broom snakeweed" usualmente germino en Abril, Mayo o Junio (83\% de un total de 394), principalmente en 1991 y 1992 (81\% del total) cuando la humedad en primavera fue suficiente. La mayoría de las plántulas de "Broom sankeweed" (52\% del total) emergieron el primero o segundo año después de la quema de verano, especialmente en áreas donde el rendimiento y cobertura del zacate disminuyeron y la cantidad de suelo desnudo aumento como resultado de fuegos intensos. Los fuegos de primavera causaron menos daño al "Blue grama" que los fuegos de verano, y el número de plántulas producidas de "Broom sankeweed" (18\% del total) fue similar al del pastizal no tratado ( $22 \%$ del total), pero menor que las producidas en otras áreas quemadas en verano. El rendimiento y cobertura del zacate se incrementaron dentro del año en que se asperjo el herbicida y las parcelas tratadas tuvieron significativamente ( $P$ < 0.05) menos plántulas de "Broom snakeweed" que las áreas quemadas y las no tratadas.

establishment of low seral species, including broom snakeweed. Establishment of broom snakeweed seedlings shortly after burning can negate the economic benefits that are expected to accrue from prescribed fire (Torell et al.1989).

Research investigating broom snakeweed germination (Kruse 1970, Mayeux and Leotta 1981, Mayeux 1983), dispersal (Wood et al. 1997), and seed bank storage (Osman and Pieper 1988) have provided insight into how this species establishes on southwestern U.S. rangelands. Other research has focused on seedling survival (Nadabo et al. 1980), longevity (McDaniel 1989), and population dynamics (Torell et al. 1992). Broom snakeweed control by herbicides and the subsequent establishment of herbage and broom snakeweed has been reported in a number of studies (McDaniel and Duncan 1987, McDaniel 1989). In this study we examine some of the circumstances under which broom snakeweed is likely to establish after prescribed fire relative to herbicide spraying or no treatment. We specifically addressed the following 3 questions concerning broom snakeweed establishment on blue grama grasslands: (1) Under what conditions is seedling emergence most likely to occur? (2) What fire characteristics are likely to produce micro-sites favorable for seed germination? and (3) Can prescribe fires be conducted in ways to minimize broom snakeweed establishment? 


\section{Materials and Methods}

\section{Description of Area}

The study was conducted on the New Mexico State University Corona Ranch, about $23 \mathrm{~km}$ northeast of Corona, N. M. Two study sites were located about $10 \mathrm{~km}$ apart on blue grama dominated grasslands with level terrain and elevation near 1,870 $\mathrm{m}$. Soils on both sites are comprised of the Taipa-Dean loam association, which are shallow and underlain by impervious limestone bedrock. The Taipa loam is classified as a fine-loamy, mixed, mesic, Ustollic Haplargid, and the Dean loam is a fine, carbonatic, mesic, Ustollic Caliciothid. Surface texture is a sandy loam to loam and soil depth is $0.5 \mathrm{~m}$ or less. Formed from piedmont deposits and derived from limestone quartzite and igneous rock, these soils are subject to wind erosion and are poorly drained, thus surface runoff is moderate to high (USDA 1970).

The NMSU Corona Ranch is characterized by a semiarid, continental climate with an average diurnal temperature range near $15^{\circ} \mathrm{C}$ (USDA 1970). Average daily maximum temperatures range from $6.4^{\circ} \mathrm{C}$ in January to $14.7^{\circ} \mathrm{C}$ in July. In summer, maximum daytime temperatures exceed $32^{\circ}$ about 30 days each year. The growing season, or freeze-free season, is about 155 days a year. Average annual relative humidity is about $50 \%$, but in late winter and early spring the daily average is about $30 \%$ and frequently falls below $15 \%$ by midday.

The primary sources of rain and snow in the region are from storms originating from the Pacific Ocean and the Gulf of Mexico. Winter precipitation is mainly snow, which averages $51 \mathrm{~cm}$ a year, and normally does not stay on the ground more than a few days (USDA 1970). Summer precipitation occurs mostly as intense, local, convectional thunderstorms of short duration. Mean annual precipitation averages $38 \mathrm{~cm}$ with about one-half this amount occurring from July to September.

Blue grama dominates the understory vegetation, but other important perennial grasses include wolftail (Lycurus phleo sides [H.B.K.]), sand dropseed (Sporobolus cryptandrus [Torr.] A. Gray), squirreltail (Elymus longifolius [Smith] Gould), and three awns (Aristida sp.). Broadleaf herbs are relatively uncommon, with scarlet globe mallow (Sphaeralcea coccinea (Nutt.) Rybd.) and verbena (Verbena bracteata Lag. \& Rodr.) most important. Winterfat (Ceratoides lanata [Pursh] J.T. Howell) and cholla are scat- tered throughout the area, but broom snakeweed dominates the over story vegetation. Mature broom snakeweed is 15 to $45 \mathrm{~cm}$ in height and its spatial distribution ranges from irregular dense patches to widely scattered individuals. The relative dominance of broom snakeweed in this area varies through time and may be viewed as an increaser on disturbed grasslands (Pieper and McDaniel 1989).

\section{Fire and Herbicide Treatments}

Treatments were applied to 20 - by 26.5 $\mathrm{m}$ plots arranged in a randomized complete block with 3 replications within the 2 study enclosures. Treatments in 1990 consisted of prescribed burns on 17 March (spring) and 13-14 June (summer); a herbicide spray using picloram (4-amino 3,5,6,trichloro-2-pyridinecarboxylic acid) at $0.42 \mathrm{Kg} \mathrm{ha}^{-1}$ applied with a trailermounted broom sprayer (6.4-m boom) on $26 \mathrm{March}$; and untreated controls. These treatments were reapplied to adjacent plots in 1991. High winds in spring 1991 prevented us from applying treatments to both sites at the same time, so burns were conducted on 20-23 March and 25-27 June at Site 1; and 5-6 April and 7-8 July at Site 2. Herbicide sprays were applied on 11 March at Site 1 and 5 April at Site 2 using a hand held $\mathrm{CO}_{2}$ sprayer (3.3-m boom).

Burns were started as head fires using a hand-held drip torch containing a 1:1 gasoline-diesel oil mixture. Around each plot a 6.7-m buffer was installed using a grader to remove vegetation and to create a mineral break. A detailed description of the methods used to characterize each burning event has been described elsewhere (McDaniel et al. 1997). Burns for this experiment were conducted near the prescribed environmental conditions recommended by Wright and Bailey (1982) for general burning of low-volatile fuels typical of blue grama grasslands. They suggested burning a head fire with air temperatures between 21 to $27^{\circ} \mathrm{C}$, relative humidity 20 to $40 \%$, wind speed from 3.6 to $6.5 \mathrm{~m} \mathrm{sec}^{-1}$ and wind direction from the southwest. While we tried to adhere to this prescription, we rarely experienced all of the weather requirements. Thus some burns were conducted outside the recommended air temperatures or relative humidity ranges (Carroll 1994, Hart1992).

\section{Seedling Monitoring}

After treatments were applied, nine, 1$\mathrm{m}^{2}$ permanent subplots were arranged inside every main plot using 3 by 3 equally spaced rows to monitor broom snake- weed seedling emergence and survival. Metal spikes $(10 \mathrm{~cm})$ marked the corners and nylon twine defined the perimeter of each subplot. Mature broom snakeweed plants within each subplot were initially mapped in a notebook and tagged with a common colored (telephone) wire secured around the plant's base for future identification. Beginning 1 month after treatment, subplots were visited near mid-month through October 1998 to mark and map newly emerged seedlings and to census survival of previously tagged plants. New seedlings were color coded to indicate the month of emergence on the subplot diagram. Death of a seedling was similarly denoted by circling the colored mark with the corresponding month of death. Thus, individual life spans for each seedling could be determined. The proximity of each newly emerged seedling was measured in relation to the nearest live grass plant and later was grouped as emerging within grass or emerging outside grass (bare ground). Data collected within the subplots allowed us to compare broom snakeweed emergence and survival over time, and to determine seedling differences among burned, herbicide, or nontreated areas. Differences in the total seedling number produced by treatment over the various collection dates were analyzed using the GLM procedure within SAS (1984). The experimental design was a randomized complete block with site by replication by year as the error term. Means were compared by Fisher's Protected LSD test using the 5\% probability level.

\section{Influence of Burning on Seedling Emergence}

In 1991, 27 fires were conducted in spring (20 March to 6 April) and 15 fires in summer (25 June to 8 July) under varying fuel load and air temperature regimes for the purpose of developing a burning prescription for maximizing broom snakeweed control with fire (McDaniel et al. 1997). Burning procedures and simple statistics related to conditions before, during, and after these fires have been discussed elsewhere (Hart 1992, McDaniel et al. 1997). The next year (August 1992) it was visibly obvious after walking across burned plots that broom snakeweed seedlings were more abundant on areas burned in summer than spring. Also, we noticed that seedling numbers were not equal among plots burned during the same season, and this offered us the opportunity to compare differences in broom snakeweed emergence after these fires. 
Pre-burn vegetation measurements had been obtained in each plot using ten, 31.5 by $61 \mathrm{~cm}$ permanently marked quadrats (McDaniel et al. 1997). These quadrats were placed along 2 diagonal lines across each plot from corner to opposite corner. Pre-burn measurements included aerial cover, density, and yield of broom snakeweed and grass. The same vegetational information collected during pre-burn measurements was also obtained every October from 1991 through 1998. Environmental variables monitored during each burn, and reported in McDaniel et al. (1997), included air temperature, soil temperature at $10 \mathrm{~cm}$, relative humidity, wind speed, and wind direction. Fire characteristics evaluated included fire temperatures measured with thermocouples and heat sensitive tablets, rate of fire spread, duration of heat, and degree seconds of heat (Hart 1992, McDaniel et al. 1997).

For purposes of this study, broom snakeweed seedlings were counted in each plot in August 1991, 1992, and 1993 using the same 10 permanent quadrats used to obtain other pre- and post-burn vegetation data. This allowed a comparison of seedling density after burning to average pre-burn, climatic, fire, and post-burn measurements in each plot. Few seedlings were counted in 1991 and 1993; thus only 1992 data are reported. Simple linear and nonlinear regression analyses, and stepwise discriminant analyses (SAS 1984), were conducted with total seedling number per plot as the dependent variable. Environmental, fire, and pre- and postburn vegetation measurements were used as independent explanatory variables to relate seedling establishment separately and combined across burning seasons. To examine these differences, least squares regression analysis were performed to evaluate the relationship between the 1992 seedling counts and 1991 burning information. The 1991 post-burn vegetation data were used because $83 \%$ of seedlings counted in 1992 emerged during the second quarter of the year (April to June). Thus, peak emergence had taken place before the growth of warm season perennial grasses in 1992 .

\section{Results and Discussion}

\section{Seedling Emergence and Survival}

During the 9-year study period (1990-1998), annual precipitation at Corona, N.M. was near or slightly above the long-term average every year except 1993 and 1995, which were $28 \%$ and $38 \%$
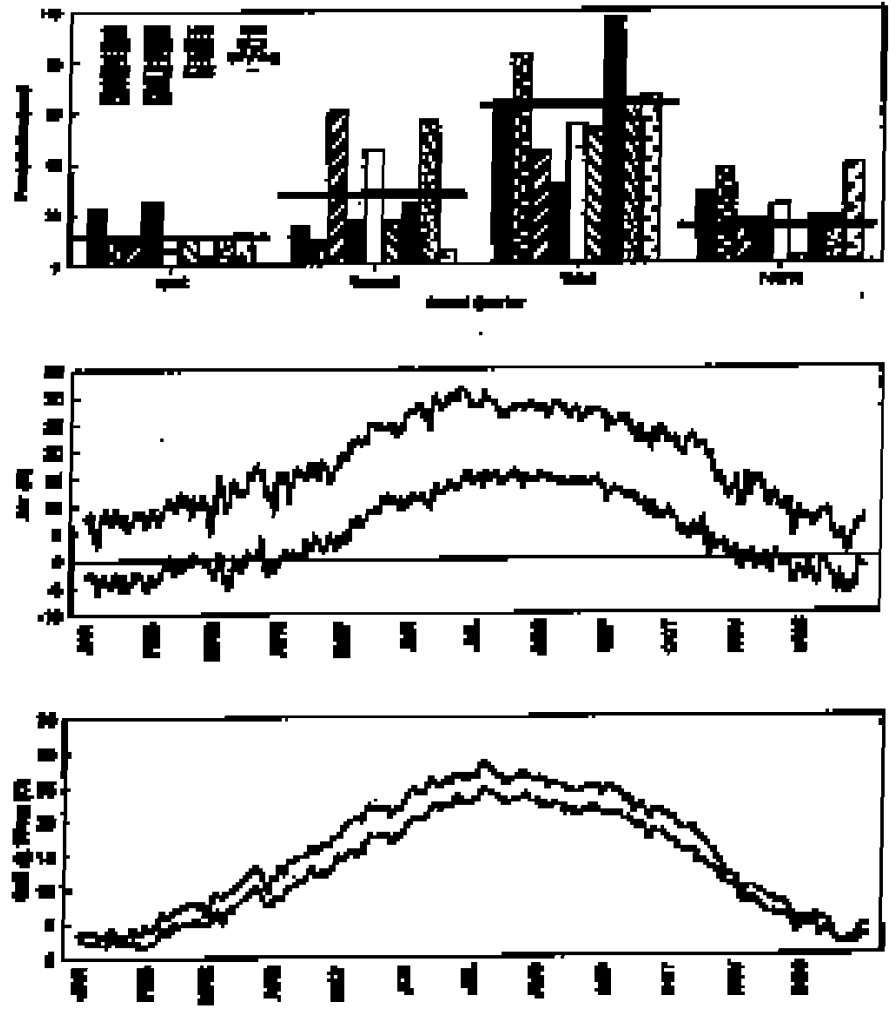

Fig. 1. Precipitation by quarters, and average minimum and maximum air and soil temperatures from 1990 to 1998 on the NMSU Corona Ranch.

below normal (Fig. 1); thus moisture conditions were seemingly favorable for broom snakeweed propagation and survival. Broom snakeweed seed can potentially germinate any month (Lane 1985), but during the course of this study fewer than $2 \%$ of new seedlings were counted in the first (January-March ) or fourth (October-December) quarters of the year (Table 1). About $15 \%$ of seedlings emerged in the third quarter (July-September) when rain fall is usually most abundant. Air and soil temperatures, however, are elevated in these summer months and this probably reduces germination (Fig. 1). Kruse (1979) and Mayeux (1983) reported that broom snakeweed germination ceases when growth chamber temperatures exceed about $30^{\circ} \mathrm{C}$.

The majority $(83 \%)$ of broom snakeweed seedlings emerged during the second quarter (April-June), irrespective of year, site, or treatment (Table 1). This period roughly coincides to when alternating air and surface soil temperatures (10 $\mathrm{cm}$ depth) on our study area are near a 10 to $25^{\circ} \mathrm{C}$ range (Fig. 1). Kruse (1979) and Mayeux (1989) reported that optimal broom snakeweed germination occurs when growth chamber temperatures range between 10 to $25^{\circ} \mathrm{C}$, under an 8-hour light period. An examination of average mini- mum and maximum soil temperatures during the second quarter indicates this optimal range occurs in the spring for about 6 to 8 weeks (about mid April to mid June). Interestingly, soil temperatures on our study area increase gradually in spring but decline rapidly in the fall; thus the optimal temperature range is shorter in autumn (Fig. 1). This may partially explain why few seedlings were counted in the fourth

Table 1. Absolute number of broom snakeweed seedlings counted, irrespective of treatment, from 2 study sites on the NMSU Corona Research Ranch. Counts were made monthly in nine, $1-\mathrm{m}^{2}$ subplots placed in each main plot (3 reps $x 4$ treatments $x 3$ months per quarter).

\begin{tabular}{lccccr}
\hline \hline & \multicolumn{5}{c}{ Seedling emergence by annual quarters } \\
\cline { 2 - 6 } Year & First & Second & Third & Fourth & Total \\
\hline 1990 & 0 & 3 & 4 & 0 & 7 \\
1991 & 0 & 52 & 14 & 0 & 66 \\
1992 & 2 & 211 & 34 & 6 & 253 \\
1993 & 1 & 7 & 1 & 0 & 9 \\
1994 & 0 & 17 & 2 & 0 & 19 \\
1995 & 0 & 6 & 2 & 0 & 8 \\
1996 & 0 & 7 & 0 & 0 & 7 \\
1997 & 0 & 5 & 1 & 0 & 6 \\
1998 & 0 & 18 & 1 & 0 & 19 \\
Total & 3 & 326 & 59 & 6 & 394 \\
\hline
\end{tabular}

First quarter, January, February, March; second, April, May, June; third, July, August, September; fourth, October, November, December 
Table 2. Broom snakeweed emergence in relation to distance from individual grass plants, and seedling survival through the first growing season, irrespective of year, site, or treatment, on the NMSU Corona Research Ranch.

\begin{tabular}{lcc}
\hline \hline \multirow{2}{*}{ Distance } & \multicolumn{2}{c}{ Seedlings } \\
\cline { 2 - 3 } (cm) & $(\%)$ & $(\%)$ \\
0 (within grass clump) & 29 & 80 \\
$1-3$ & 54 & 74 \\
$4-6$ & 15 & 83 \\
$7-11$ & 2 & 83 \\
\hline
\end{tabular}

Percent based on 394 seedlings.

${ }^{2}$ Percent of seedlings alive through first growing season.

quarter. Also, minimum air temperatures when broom snakeweed seed normally begins to disperse in late October are often near freezing, which probably impedes germination (Wood et al. 1997). Contributing to low fall germination may be the need for an after ripening period, which Mayeux and Leotta (1981) reported favors broom snakeweed germination.

In 1992, second quarter rainfall was $224 \%$ above normal and resulted in the highest yearly number of seedlings counted $(64 \%$ of study total, Table 1$)$. Relatively few seedlings emerged in 1990, 1993,1995 , or 1996 (4\% of total) when second quarter precipitation was below the 30 -yr average (Fig. 1). Precipitation was also below normal in the second quarter of 1991 but a single rain event on 13 May provided $26 \mathrm{~mm}$ of moisture and led to the second highest annual seedling total with most counted in mid-June. After this storm we noted the soil surface was saturated and remained wet for about 5 days. We speculate a storm of this intensity is near the minimum required to provide sufficient moisture to imbide seed and to allow germination. In greenhouse studies, Wood et al. (1997) reported optimum broom snakeweed germination occurs when soils are maintained at a minimum matric potential $>-180 \mathrm{kPA}$ for at least 4 days. In contrast, 1997 second quarter precipitation was nearly $200 \%$ above normal and only 6 seedlings emerged within all study plots at both sites. The low number of seedlings produced in 1997 may be because the seed bank held few viable broom snakeweed seed to support a new population. We speculate on this possibility because precipitation was below normal from beginning the first quarter of 1995 through the second quarter of 1996 and this drought caused the death of most adult broom snakeweed plants and resulted in a lack of seed production. Additionally, in 1995 highest average summer air temperatures ever recorded near Corona occurred and this contributed to a lack of flowering and loss of adult broom snakeweed plants. Broom snakeweed seed under natural conditions are not long-lived as most become non-viable within a year of being dispersed (Wood et al. 1997); thus, with essentially 2 years of no seed production it is likely that the seed bank was largely depleted when adequate soil moisture became available in spring 1997.

Irrespective of site, year, or treatment, the emergence of broom snakeweed seedlings in relation to a ground cover was distinct. About $71 \%$ germinated in open bare ground areas, whereas the remainder emerged directly within surrounding grass (Table 2). Percent aerial grass cover was variable over years and treatments, but usually exceeded $60 \%$, whereas bare ground cover was below $25 \%$ (data not shown). A higher proportion of seedling emergence within open areas suggest a negative association with the grass overstory, which agrees with the observation that broom snakeweed is less prominent under increasing grass cover than in open disturbed areas (Jameson 1966, 1970, Ueckert 1979, Pieper and McDaniel 1989). Reduced emergence within grass may partially be related to a light requirement needed for normal germination by this species (Mayeux 1989). Interestingly, broom snakeweed survival through the first 2 growing seasons was equal (about $80 \%$ ) among seedlings that emerged either within or outside grass plants (Table 2). This suggests that, once established, seedling survival to an adult may be more dependent on soil moisture and other environmental conditions than the presence of grass.

Seedling longevity was influenced by the date propagules emerged, and the amount and frequency of rainfall received, especially through the first growing season (Table 3). Broom snakeweed seedlings are vulnerable to dessication because they do

Table 3. Broom snakeweed seedling survival by year, irrespective of treatment or site on the NMSU Corona Research Ranch.

\begin{tabular}{|c|c|c|c|c|c|c|c|c|c|c|}
\hline \multirow[b]{2}{*}{$\begin{array}{l}\text { Year } \\
\text { Emerged }\end{array}$} & \multirow[b]{2}{*}{$\begin{array}{l}\text { Number } \\
\text { Emerged }\end{array}$} & \multicolumn{8}{|c|}{ Survival at end of growing season } & \multirow[b]{2}{*}{1998} \\
\hline & & 1990 & 1991 & 1992 & 1993 & 1994 & 1995 & 1996 & 1997 & \\
\hline 1990 & 7 & 0 & 0 & 0 & 0 & 0 & 0 & 0 & 0 & 0 \\
\hline 1991 & 66 & - & 40 & 30 & 28 & 24 & 10 & 0 & 0 & 0 \\
\hline 1992 & 253 & - & - & 220 & 195 & 167 & 99 & 8 & 6 & 5 \\
\hline 1993 & 9 & - & - & - & 7 & 6 & 3 & 1 & 1 & 1 \\
\hline 1994 & 19 & - & - & - & - & 16 & 11 & 1 & 1 & 1 \\
\hline 1995 & 8 & - & - & - & - & - & 11 & 1 & 1 & 1 \\
\hline 1996 & 7 & - & - & - & - & - & - & 1 & 1 & 1 \\
\hline 1997 & 6 & - & - & - & - & - & - & - & 2 & 2 \\
\hline 1998 & 19 & - & - & - & - & - & - & - & - & 17 \\
\hline
\end{tabular}

not quickly develop an extensive root system to exploit soil water and nutrient resources (Osman and Pieper 1988). Excavations of entire seedlings in the field indicate root penetration is about $9.5 \mathrm{~cm}$ after 5 weeks, but only $27 \mathrm{~cm}$ after 29 weeks in southern New Mexico (Osman 1982). As the plant matures, it develops an efficient, shallow, fibrous root system that gives it access to soil water at about the same depth as associated perennial grasses (Ragsdale 1969, DePuit and Caldwell 1975). In this study, all seedlings that emerged in 1990 died the first season. However, most seedlings produced between 1991 to 1995 survived (60 to $89 \%$ ) through the first growing season and later matured to flower the second year. Some 1991 to 1995 seedlings died annually (Table 3), mostly as a result of dry hot conditions in June or July; all but 11 of the original 365 seedlings produced through this time succumbed to 1995-1996 drought conditions. Eight of these seedlings were still alive when the study terminated in October 1998.

\section{Broom Snakeweed Emergence After Treatment}

In the study, most broom snakeweed seedlings emerged in 1991 and 1992; thus statistical comparisons between treatments were only made for these years (Table 4). Plots burned in summer 1990 had significantly $(\mathrm{P}<0.05)$ more broom snakeweed seedlings the next year than untreated areas; and more seedlings than spring burned and herbicide treated areas the next 2 years. There was an equivalent number of broom snakeweed seedlings in 1990 spring burned and non-treated areas the first year, but fewer seedlings emerged in the spring burned plots the second year. Only 11 seedlings emerged over the 9 year study in plots sprayed with herbicide in 1990, which was less than those counted in spring and summer burned and non-

\section{treated areas.}


Table 4. Total number of broom snakeweed seedlings produced annually within treatments from 1990 through 1998 on the NMSU Corona Research Ranch.

\begin{tabular}{|c|c|c|c|c|c|c|c|c|c|c|c|}
\hline \multirow[b]{2}{*}{$\begin{array}{l}\text { Treatment } \\
\text { Total }\end{array}$} & \multirow{2}{*}{$\begin{array}{c}\text { Year } \\
\text { Applied }\end{array}$} & \multicolumn{9}{|c|}{ Annual Seedling Total $^{1}$} & \\
\hline & & 1990 & 1991 & 1992 & 1993 & 1994 & 1995 & 1996 & 1997 & 1998 & \\
\hline Non-Treated & & 3 & $11 \mathrm{~b}$ & $20 \mathrm{~b}$ & 1 & 6 & 2 & 2 & 0 & 4 & 49 \\
\hline Spring burn & 90 & 3 & $12 b$ & $14 \mathrm{c}$ & 2 & 1 & 1 & 0 & 2 & 4 & 39 \\
\hline Summer burn & 90 & 1 & $42 \mathrm{a}$ & $21 \mathrm{~b}$ & 0 & 2 & 0 & 5 & 0 & 1 & 72 \\
\hline Herbicide & 90 & 0 & $1 \mathrm{c}$ & $3 d$ & 1 & 2 & 0 & 0 & 4 & 0 & 11 \\
\hline Spring burn & 91 & - & - & $35 \mathrm{~b}$ & 1 & 1 & 0 & 0 & 0 & 3 & 40 \\
\hline Summer burn & 91 & - & - & $146 \mathrm{a}$ & 2 & 5 & 3 & 0 & 0 & 4 & 160 \\
\hline Herbicide & 91 & - & - & $14 \mathrm{c}$ & 2 & 2 & 2 & 0 & 0 & 3 & 23 \\
\hline
\end{tabular}

From treatments applied in 1991, summer burned areas accounted for nearly $68 \%$ of the total number of broom snakeweed seedlings that emerged the next year (i.e. 1992; Table 4). New seedlings in 1991 spring burned and non-treated areas were similar, and again the fewest number of seedlings were produced in herbicidesprayed plots. The trend of a relatively high number of seedlings the year after summer burning compared to other treatments indicates that fire probably does not harm seed already distributed on the surface, nor does it later impede broom snakeweed germination. The relatively low number of seedlings in herbicide treated areas compared to burned areas may partially be attributed to the enhancement of grass cover after spraying (Mc Daniel and Duncan 1987). Although spring and summer fires and herbicide spraying eliminated most of the mature broom snakeweed plants after one year (Mc Daniel et al. 1997), the fires always increased bare ground exposure and reduced grass cover relative to herbicide spraying (Table 5; Hart 1992, Carroll 1994).

\section{Influence of Fire on Emergence}

In August 1992, broom snakeweed seedlings were more abundant $(\mathrm{P}<0.05)$ in the 15 plots burned in summer than the 27 plots burned in the spring $1991(2.0 \pm 1.9$ and $0.59 \pm 0.83$ seedling $\mathrm{m}^{-2}$ respectively). There was wide variability among plots in seedling emergence ranging from 0 to 3 seedlings $\mathrm{m}^{-2}$ after spring burning, and 0 to 6 seedlings $\mathrm{m}^{-2}$ after summer burning.

Least squares regression analysis revealed no significant correlation between broom snakeweed emergence and any of the climatic, fire, or pre-and post-burn vegetation data from spring-burned plots (Table 6). Multiple regression analysis with fire and post-burn vegetation variables accounted for less than $20 \%$ of the varia- tion in seedling density following spring burning (data not shown). It was noted by McDaniel et al. (1997) that fires in spring moved faster and burned cooler relative to summer fires, and subsequently resulted in less damage to blue grama. We speculate that when grass growth recovers quickly after fire, then the likelihood for broom snakeweed reestablishment is reduced.

As air temperatures and total fuel biomass increased during summer burning, so too did fire temperatures, total burn time, duration of heat, and degree-seconds of heat (McDaniel et al. 1997). When fires became very intense and produced excessive heat, then post-burn grass yield and cover was reduced for 2 or more years (Hart 1992). Broom snakeweed seedlings were negatively related to increasing grass

Table 5. Percent aerial cover of broom snakeweed, grass, herbs, winterfat, litter, and bare ground when sampled in September 1990 and 1991 after broom snakeweed control on the NMSU Corona Research Ranch.

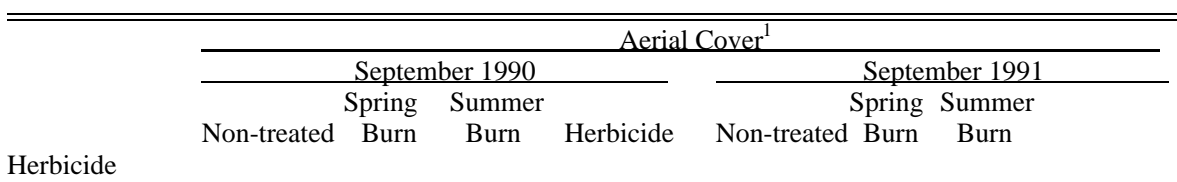

Herbicide

\begin{tabular}{|c|c|c|c|c|c|c|c|c|}
\hline \multicolumn{9}{|l|}{1990 Treatments } \\
\hline Broom Snakeweed & $8 \mathrm{a}$ & $0.7 \mathrm{~b}$ & $0.7 \mathrm{~b}$ & $0.0 \mathrm{~b}$ & $11 \mathrm{a}$ & $1 b$ & $1 b$ & $0.0 \mathrm{~b}$ \\
\hline Grass & $66 c$ & $70 b$ & $62 c$ & $76 a$ & $70 b$ & $74 b$ & $72 b$ & $86 \mathrm{a}$ \\
\hline Herbs & $4 b$ & $4 b$ & $7 \mathrm{a}$ & $0.03 \mathrm{c}$ & $3 b c$ & $4 a b$ & $6 a$ & $1 \mathrm{c}$ \\
\hline Winterfat & $1 \mathrm{a}$ & $1 \mathrm{a}$ & $1 \mathrm{a}$ & $0.2 \mathrm{a}$ & $2 \mathrm{a}$ & $1 \mathrm{a}$ & $1 \mathrm{a}$ & 1a \\
\hline Litter & $5 b$ & $3 c$ & $2 \mathrm{c}$ & $12 \mathrm{a}$ & $6 a$ & $5 a$ & $6 a$ & $5 \mathrm{a}$ \\
\hline Bare ground & $15 \mathrm{bc}$ & $22 \mathrm{ab}$ & $27 \mathrm{a}$ & $12 \mathrm{c}$ & $9 b c$ & $13 \mathrm{ab}$ & $15 \mathrm{a}$ & $7 \mathrm{c}$ \\
\hline \multicolumn{9}{|l|}{1991 Treatments } \\
\hline Broom Snakeweed & - & - & - & - & $11 \mathrm{a}$ & $4 b$ & $1 b$ & $2 b$ \\
\hline Grass & 一 & - & - & - & $70 \mathrm{~b}$ & $70 \mathrm{~b}$ & $60 \mathrm{c}$ & $80 a$ \\
\hline Herbs & 一 & - & 一 & - & $3 b$ & $4 b$ & $15 \mathrm{a}$ & $2 b$ \\
\hline Winterfat & 一 & - & - & - & $2 \mathrm{a}$ & $2 \mathrm{a}$ & $0 \mathrm{a}$ & $2 a$ \\
\hline Litter & 一 & 一 & 一 & - & $6 a$ & $7 \mathrm{a}$ & $8 a$ & $7 \mathrm{a}$ \\
\hline Bare ground & - & - & - & - & $9 \mathrm{ab}$ & $13 a$ & $15 \mathrm{a}$ & $7 b$ \\
\hline
\end{tabular}

${ }^{1}$ Means within rows and sample date with the same letters are not different $(\mathrm{P}<0.01)$. Treatments were replicated 3 times at 2 sites within years. Analysis of variance revealed no difference $(\mathrm{P}<0.01)$ among sites so data were pooled for final analyses. w.M. broom snakeweed emer- yield $(r=-0.73)$ and positively related to increasing bare ground cover $(\mathrm{r}=0.69)$. About $9 \%$ of seedlings emerged in spring and summer burned plots averaging less than $10 \%$ bare ground cover, whereas the remainder emerged where bare ground exposure was higher.

\section{Management Implication}

On our study area near Corona, NM, broom snakeweed propagation was most common in the second quarter (April, May, and June) with moist surface soil temperatures ranging between 10 to $25^{\circ} \mathrm{C}$. Broom snakeweed seed can potentially germinate any time during a year, and we suspect that propagation elsewhere will depend on localized soil temperature and moisture conditions. For example, while little propagation was noted on our study area during the first or fourth quarters of ear, under a milder climate near Las gence was common in January and (Barnett 1996) propagation was irregular with only 1991 and 1992 having a substantial number of was higher in these years than others. Rainfall was plentiful the year after treatments were established. Also, although most adult broom snakeweed plants were killed by the burning and herbicide treatments, there was still a high number of potential progeny in the seed bank the first 
Table 6. Simple linear correlation coefficients obtained on 1991 spring and summer burns with dependent variable snakeweed seedlings $\mathbf{m}^{-2}$.

\begin{tabular}{|c|c|c|c|}
\hline \multirow[b]{2}{*}{ Variables } & \multicolumn{3}{|c|}{ Correlation Coefficients } \\
\hline & Spring & Summer & Combined \\
\hline \multicolumn{4}{|l|}{ Pre-burn Data } \\
\hline Grass Cover & -.09 & -.33 & -.05 \\
\hline Snakeweed Cover & -.02 & .26 & .08 \\
\hline Litter Cover & .12 & .26 & $-.23^{*}$ \\
\hline Bareground Cover & .15 & .25 & .10 \\
\hline Grass Yield & -.18 & -.28 & -.01 \\
\hline Snakeweed Yield & -.15 & .33 & -.04 \\
\hline Snakeweed Density & -.07 & .33 & .06 \\
\hline Grass Moisture & -.25 & -.43 & -.05 \\
\hline Snakeweed Moisture & .25 & -.43 & .07 \\
\hline Soil Moisture & .25 & .43 & $-.30 * *$ \\
\hline \multicolumn{4}{|l|}{ Climatic Data } \\
\hline Air Temperature & .11 & $.59 * *$ & $.51 * * *$ \\
\hline Soil Temperature & .16 & .29 & $.48^{* * *}$ \\
\hline Wind Speed & -.07 & .34 & .16 \\
\hline Relative Humidity & -.12 & $-.50 *$ & $-.32 * *$ \\
\hline Wind Direction & -.18 & $.58 * *$ & $-.25^{*}$ \\
\hline \multicolumn{4}{|l|}{ Fire Measurements } \\
\hline Total Burn Time & .07 & $-.59 * *$ & -.12 \\
\hline Max. Therm. Temp. & .02 & $.58^{* *}$ & $.41 * * *$ \\
\hline Tempil-Strip-Temp. & .16 & $.65 * * *$ & $.60 * * *$ \\
\hline Rate of Spread & .20 & $.65^{* * *}$ & $.29 *$ \\
\hline Duration of Heat & .13 & .22 & $.31 *$ \\
\hline Deg. Seconds Heat & -.003 & $.46^{*}$ & $.44 * * *$ \\
\hline \multicolumn{4}{|l|}{ Post-Burn Data } \\
\hline Grass Cover & .03 & -.23 & -.20 \\
\hline Snakeweed Cover & -.31 & -.39 & -.21 \\
\hline Litter Cover & .19 & $.48 *$ & $.50 * * *$ \\
\hline Bareground Cover & -.09 & $.69 * * *$ & .03 \\
\hline Grass Yield & -.30 & $-.73 * * *$ & .12 \\
\hline Snakeweed Yield & -.26 & $-.46^{*}$ & $-.28 * *$ \\
\hline Snakeweed Density & -.27 & $-.47 *$ & $-.30 * *$ \\
\hline
\end{tabular}

year after treatment. Broom snakeweed seed is not long-lived, with most becoming nonviable within a year of dispersal (Wood et al 1997). Thus, if adult plants are eliminated by fire, herbicide, or natural causes, the greatest opportunity for a large number of seedlings to become established should be shortly after the death of mature plants. We speculate, based on our study, that if 1 or 2 years lapse without seedling establishment, then the return of broom snakeweed to an area will be retarded and occur only after a slow yearby-year build up of the population.

Broom snakeweed control practices that provide for greater grass yield and less bare ground exposure should act to minimize, but not necessarily prevent, future broom snakeweed propagation. In this study, herbicide spraying was the only treatment to significantly increase grass yield and cover relative to non-treated rangeland, and was the most effective control practice examined for reducing broom snakeweed establishment. Other research and commercial spraying experience has shown that with time, broom snakeweed
$3-10 \%$, and pre-burn fine-fuel moisture below $15 \%$. The fine-fuel should be uniformly distributed and exceed $500 \mathrm{~kg} \mathrm{ha}^{-1}$. Obtaining these prescribed conditions was difficult on our study area at all times of the year. However, we believe these conditions, irrespective of burning time, are capable of maximizing both broom snakeweed control while lowering the risk of seedling emergence after fire.

\section{Literature Cited}

Barnet, B. L. 1996. Influence of winter precipitation on broom snakeweed establishment in the Chihuahuan Desert. M.S. Thesis, New Mexico State Univ., Las Cruces, N.M.

Carroll, D. B. 1994. Broom snakeweed seedling response to spring and summer burning in central New Mexico. M. S. Thesis, New Mexico State Univ., Las Cruces, N.M.

De Pruit, E. J. and M. M. Caldwell. 1975. Gas exchange of three cool season semidesert species in relation to temperature and water stress. J. Ecol. 63:835-859.

Hart, C. R. 1992. Broom snakeweed and associated herbage response to seasonal burning in New Mexico. Ph. D. Diss., New Mexico State Univ., Las Cruces, N. M.

Jameson, D. A. 1966. Competition in a blue grama - broom snakeweed actinea community and response to selected herbicides. J. Range Manage., 19: 121-124.

Jameson, D. A. 1970. Value of broom snakeweed as a range condition indicator. J. Range Manage., 23:302-304.

Kruse, W. H. 1979. Temperature and moisture stress effect germination of Gutierrezia sarothrae Range Manage., 23:143-145.

may reestablish after herbicide control, even with a 4 to 6 fold increase in grass production (McDaniel and Duncan 1987). However, the magnitude of broom snakeweed establishment on herbicide treated areas should be less than if the rangeland were burned or not treated.

When prescribed fires are conducted in a manner so as to eliminate mature broom snakeweed plants but minimize damage to associated grasses, then there is a greater likelihood for long-lasting broom snakeweed control. In McDaniel et al. (1997) we reported less broom snakeweed control with spring fires (65\% average mortality) than summer fires (92\% average mortality). In this study, fewer broom snakeweed seedlings emerged after these same spring fires than summer fires, which brings into question, what is the optimal burning time for long-lasting broom snakeweed control? Our recommended conditions for burning blue gramma grasslands in central New Mexico (McDaniel et al. 1997) includes air temperatures from $22^{\circ} \mathrm{C}$, relative humidity $10-20 \%$, soil moisture
Lane, M. A. 1985. Taxonomy of Gutierrezia (Compositae: Astereae) in North America. Syst. Bot. 10:7-28.

Mayeux, H. S., Jr. 1983. Effect of soil texture and seed placement on emergence of four subshrubs. Weed Sci., 31:380 -384.

Mayeux, H. S. 1989. Snakeweed seed characteristics and germination requirements. p. 39-46. In: E. W. Huddleston and R. D. Pieper (ed.). Snakeweed: Problems and perspectives, New Mexico State Univ. Agr. Exp. Sta. Bull. 751, Las Cruces, N.M.

Mayeux, H. S., Jr. and L. Leotta. 1981. Germination of broom snakeweed and threadleaf snakeweed. Weed Sci. 29:530-534.

McDaniel, K. C. 1989. Use of herbicides in snakeweed management. p. 85-100. In: Huddleston and R. D. Pieper (eds.). Snakeweed: Problems and perspectives. New Mexico State Univ. Agr. Exp. Sta. Bull. 751. Las Cruces, N.M.

McDaniel, K. C. and K. W. Duncan. 1987. Broom snakeweed (Gutierrezia sarothrae) control with picloram and metsulfuron. Weed Sci. 35: 837-841.

McDaniel, K. C., C. R. Hart, and D. B. Carroll. 1997. Broom snakeweed control 
with fire on New Mexico blue grama rangeland. J. Range Manage., 50:652-659.

McDaniel, K. C., C. R. Hart, and K. W. Duncan. 1989. Use of fire in snakeweed management. p. 101-112. In: E. W. Huddleston and R. D. Pieper (eds.). Snakeweed: Problems and perspectives. New Mexico State Univ. Agr. Exp. Sta. Bull. 751. Las Cruces, N.M.

Nadabo, S., R. D. Pieper, and R. F. Beck. 1980. Growth patterns and biomass relations of Xanthocephalum sarothrae (Pursh) Shinners on sandy soils in southern New Mexico. J. Range. Manage. 33: 394-397.

Osman, A. A. 1982. Establishment of broom snakeweed and other species on semi-desert grasslands of southern New Mexico. Ph. D. Diss., New Mexico State Univ., Las Cruces, N.M.
Osman, A. A. and R. D. Pieper. 1988. Growth of Gutierrezia sarothrae seedlings in the field. J. Range Manage., 41:92-93.

Pieper, R. D. and K. C. McDaniel. 1989. Ecology and management of broom snakeweed, p. 10 In: E. W. Huddleston and R. D. Pieper (ed.). Snakeweed: problems and perspectives. New Mexico State Univ. Agr. Exp. Sta. Bull. 751. Las Cruces, N.M.

Ragsdale, B. J. 1969. Ecological and phenological characteristics of perennial broomweed. Ph.D. Diss., Texas A \& M Univ., College Station, Tex.

SAS Institute Inc. 1984. SAS/ETS User's Guide, Version 5 edition. SAS Institute, Inc. Cary, N.C.

Torell, L. A., K. C. McDaniel, and K. Williams. 1992. Estimating the life of shortlived, cyclic weeds with processes. Weed Tech. 6:62-67.
Torell, L. A., K. Williams, and K. C. McDaniel. 1989. Economics of broom snakeweed control, p. 113-140. In: E. W. Huddleston and R. D. Pieper (eds.). Snakeweed: Problems and perspectives. New Mexico State Univ. Agr. Exp. Sta. Bull. 751. Las Cruces, N. M.

Ueckert, D. N. 1979. Broom snakeweed: Effect on short grass forage production and soil water depletion. J. Range Manage. $32: 216-219$

USDA Soil Conservation Service. 1970. Soil Survey of Torrance area New Mexico. U. S. Govt. Printing Office, Washington D.C.

Wood, B. L., K. C. McDaniel, and D. Clason. 1997. Broom snakeweed (Gutierrezia sarothrae dispersal, viability, and germination. Weed Sci. 45:77-84.

Wright, H. A. and A. W. Bailey. 1982. Fire ecology, United States and Southern Canada. John Wiley \& Sons, New York.

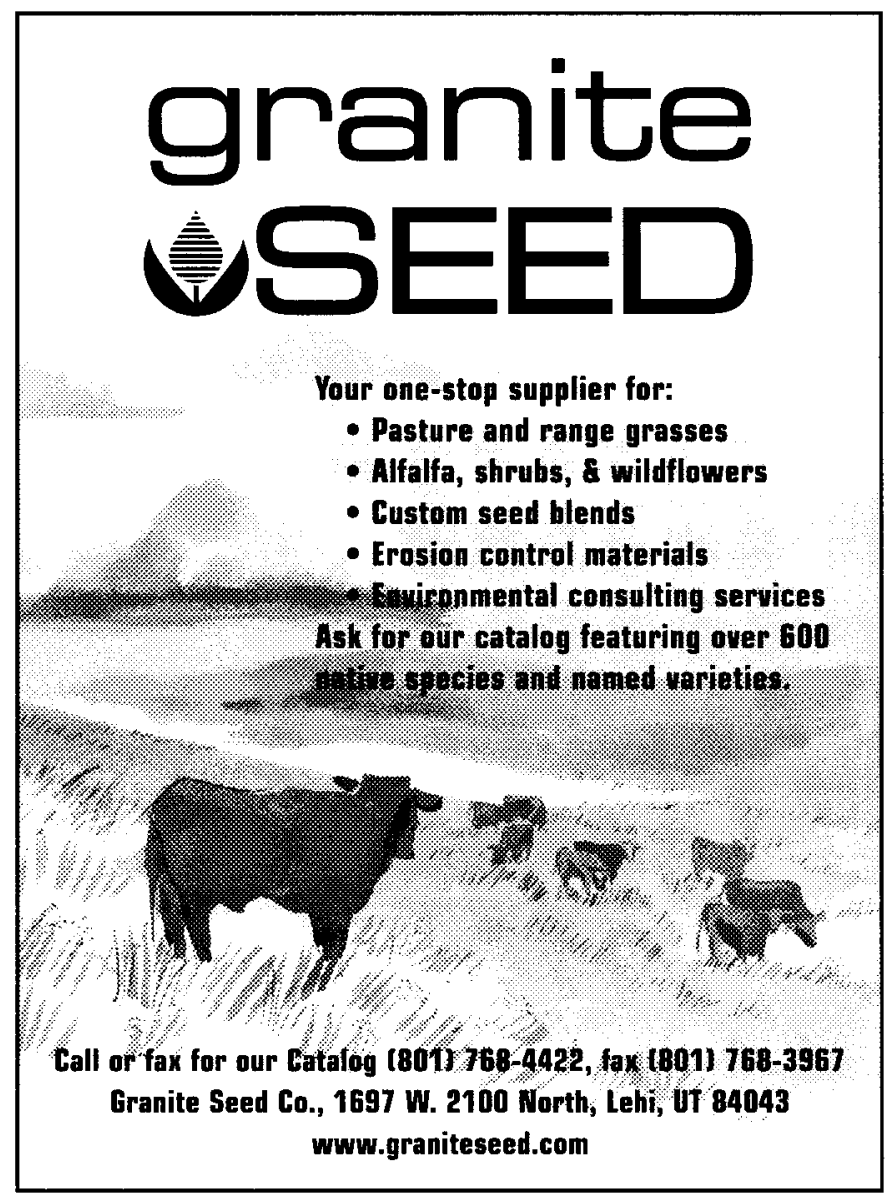




\section{B ook R eviews}

The Politics of Ecosystem Management. By Hanna J. Cortner and Margaret A. Moore. 1999. Island Press, Washington, DC, and Covelo, California. 1979 p. US\$25.00 paper. ISBN 1-55963-672-6.

How should ecosystems be managed so that such systems are ecologically sustainable in the long run? This is the central question that is studied in this book. The authors use the book's 8 chapters to analyze the above question in detail. Rather than provide a tedious chapter by chapter review, in what follows, I shall assess the contents of chapters 1,2, 5, 7, and 8. These chapters are interesting, and contain some of the more thought-provoking ideas of this book. As such, a focus on these 5 chapters should provide the reader with a good idea of the intellectual contributions of The Politics of Ecosystem Management.

Chapter 1 studies the connections between politics and ecological approaches to resource management. To their credit, the authors clearly state that the "way society chooses to deal with its public problems... will necessarily shape how ecosystem management fares in the next century" (p. 6). Moreover, this chapter notes that a key aspect of ecosystem management consists of the maintenance of the resilience of ecosystem structures and processes. Now, the term "resilience" has 2 meanings in ecology, the first due to C.S. Holling and the second due to S.L. Pimm (see the paper by C.S. Holling et al. in the 1995 book Biodiversity Loss: Economic and Ecological Issues). Which meaning do the authors have in mind? We're not quite sure because parts of the book suggest the Holling meaning, other parts suggest the Pimm meaning, and the authors never explain exactly what they mean by resilience. This omission has the unfortunate effect of muddying some of the subsequent discussion about ecosystem management.

With the recent history of U.S. resource management in the background, Chapter 2 studies the shift toward what the authors call "ecosystem management." This chapter makes 2 salient points. First, the authors point out that in recent times, "public involvement policies have resulted in a politics of interest, creating an adversarial style of public involvement in resource management dominated by national interest groups" (p. 28). Second, on the basis of this point, the authors conclude that the typical American's view of what ecosystems are, and ought to be, appears to be undergoing a fundamental shift towards a more holistic perspective.

The philosophical underpinning of ecosystem management is the subject of Chapter 5. After discussing the thinking of the Enlightenment Era, this chapter argues with some justification that Enlightenment thinking has had 4 negative effects on modern society. These effects include an emphasis on human control over nature, a narrow conception of reason, the definition of science as positivism, and the subjugation of humans by humans. In particular, as far as the definition of science as positivism is concerned, the authors note that "positivism not only....served as a tool for the mastery of nature, but....also limited the nature of scientific inquiry to preconceived categories and principles" (p. 79).
These observations are fine, but in their call for changes in the nature of scientific inquiry, the authors occasionally let their zeal get the better of them. For instance, they call for the creation of a "civic science" that "addresses the paradox of expert versus open decision making by encouraging citizens to serve as lay scientists" (p. 84). Can one implement this kind of a scheme to better serve the goal of ecologically sustainable resource management? Second, if citizens are able to serve effectively as lay scientists, then why not dispense with experts and the attendant "expert culture" altogether? These issues are inadequately addressed by the authors.

With the goal of ecological sustainability in mind, Chapter 7 focuses on the enhancement of governmental performance and democratic values. The authors note that a reexamination of extant laws, a rethinking of the notion of property rights, altering a number of administrative organizations, and an alignment of market operations will be necessary to achieve the ultimate goal of sustainability. Although this chapter makes a number of useful points, it also raises several questions. Here are 3 examples. First, it is now well known (see the paper by M. Common and C. Perrings in Ecological Economics, 1992, Vol. 6, pp. 7-34) that ecosystems - or more generally ecological-economic systemsare jointly determined. As such, it is unclear why the authors focus exclusively on ecological sustainability and not on the sustainability of the joint system.

Second, the chapter says that integrating "the goal of ecological sustainability into economic approaches....can do much to resolve the paradoxes of sustainability by avoiding the inadequacies of traditional economic conventions" (p. 127). Does this mean that an ecosystem manager's objective should be attainment of ecological sustainability with economic activities affecting the manager's task as constraints? Or, does this mean that an ecosystem manager should place equal weight on the ecological and the economic aspect of the management problem? The authors do not provide clear answers to these questions.

Finally, a key issue in ecosystem management concerns the ability of our political and other institutions to deal with issues that arise once one adopts a multidisciplinary approach to the task of managing ecosystems. For instance, consider the issue of the substitutability between different kinds of natural capital. The study of this kind of substitutability is important in ecosystem management for at least 2 reasons. First, knowledge of the substitutability between different kinds of natural capital is essential for making prudent species conservation decisions. Second, a knowledge of this kind of substitutability is helpful in valuing the stock of, say a nation's natural capital. In turn, this valuation exercise is useful (see the paper by K.G. Maler in Environmental and Resource Economics, 1991, Vol. 1, pp. 1-15) in correctly computing this nation's net national product (NNP). Very little is known about how existing political institutions would cope with this kind of substitutability issue. Consequently, the authors should have provided a much more expansive discussion of these kinds of management issues that arise in a multidisciplinary context. 
In Chapter 8, the authors speculate on the future of ecosystem management. In the course of their speculations, they make 2 significant points. First, we are rightly told that if "ecological sustainability is to assume a dominant position in natural resource management, [then] American society must embrace sweeping and profound changes...." (p. 139). Second, the authors remind us that short-term economic gains may well have to be sacrificed to protect biodiversity or prevent degradation of the reproductive capability of land or waters" (p. 140). Unfortunately, the clarity of these 2 points is muddied a little by the multiple meanings that the authors attach to the notion of sustainability. The greater part of this book focuses on the notion of ecological sustainability. However, in this last chapter, in addition to the notion of ecological sustainability, we are introduced to the notions of democratic sustainability (p. 136) and social sustainability (p. 137). Parsimony in attaching meaning to the notion of sustainability would have better served the authors in their call for a more integrated and inclusive approach to ecosystem management.

Although it is not possible to heap unqualified praise on The Politics of Ecosystem Management, the book contains much to be enthusiastic about. Consequently, it seems appropriate to conclude by noting that most of this book is worth your time.Amitrajeet A. Batabyal, Utah State University, Logan, Utah.

\section{Carbon and Nutrient Dynamics in Natural and Agricultural Tropical Ecosystcms. Edited by L.} Bergström and I.I. Kirchmann, with numerous text contributors. 1998. Oxford University Press, 198 Madison Avenue, New York, NY 10016-4314, USA. Cabinao@cabi.org. US\$90.00 cloth. ISBN 0-85199-2188.

This book was written following a symposium held in Zimbabwe to acknowledge a 10-year celebration of a Soil Biology and Fertility project in that country. Those who attended included project workers, tropical soil fertility scientists and guest researchers. All of these participants held the view that declining soil fertility is a serious problem not only in Africa but also in other tropical regions around the world. A major theme of the symposium was therefore to find ways to minimize this problem. The book includes 5 major topics, each of which is comprised of subtopics, and an index,

Part I reminds readers of the nutrient dynamics in soils. Authors in this section looked examined soil organic matter (SOM) turnover when different types of land management are applied for various tropical ecosystems. Since legumes are important in tropical soil fertility, their relationships to $\mathrm{N}$ release, soil plundering and soil organic matter (SOM) dynamics were explored. Not surprising, some legume litters readily provide nitrogen for crops, whereas those rich in tannins may hinder nitrogen uptake. Parallel to this mechanism is plant residue decomposition. In animal-based systems such as improved grasslegume tropical pastures, legumes provide aboveground litter/manure recycling that contributes to the SOM build-up. With increases in SOM there would be higher rates of carbon turnover, which lead to increased activity of soil fauna, and to soil aggregation. Land use practices such as deforestation and long-term cultivation of tropical soils lead to reduced levels of SOM, which impact aggregate stability by increasing the dispersion of clays in water.
Part II deals with crop residue decomposition. Authors in this section discussed some low-input means for soil fertility management based on locally available biological resources. Incorporating high quality tree prunings, nitrogen-15-labeled maize residues in Zimbabwean soils increased maize yields due to improvements in nitrogen availability and uptake. Similarly, the use of coffee husks in Ugandan banana production resulted in substantial increases in banana yields. Thus, litter and crop residues represent valuable organic resources for small-scale African farmers who cannot afford to use industrial fertilizers. Equally important is the quality of such plant residues because of their influence on residue decomposition and nutrient release.

Part III examined tree-soil-crop interactions in agroforestry systems. Influence of the canopy on understory vegetation and soils was reviewed from a low-cost and low-technology agricultural systems perspective. The studies illustrated that trees and shrubs in arid areas may improve soil fertility of soils below their crowns. Others found that rain and sunlight are intercepted by woody vegetation, minimizing their impact on the soil beneath tree/shrub canopies. As tree/shrub canopies and other characteristics are likely to change, however, ecosystem and landscape level changes are questionable, requiring more studies that would also consider global climate change. Models can provide useful tools for understanding the functioning of agroforestry systems, not just at a specific location or ecoregion, but also for other areas.

Part IV of the book dealt with ecosystem dynamics. Authors in this section compared natural ecosystems and agroecosystems, focusing on carbon (C) and the best ways to achieve nitrogen management practices. When natural vegetation replaced by crops, soil organic matter usually declines. Differences in $\mathrm{C}$ occurred within $5 \mathrm{~cm}$ of the topsoil, maize fields having $50 \%$ less soil organic $\mathrm{C}$ than adjacent natural woodland. Even though the soil fauna density, biomass, and diversity were higher in natural systems, spatial variability resulted in lower $\mathrm{C}$ in the woodlands than in maize fields. A simulation study that assessed $\mathrm{N}$ uptake and leaching in maize fields resulted in reduced $\mathrm{N}$ uptake, which reflected soil-water stress in low rainfall seasons.

Part V, which is the final chapter of the book, discussed the present and future of agriculture in the tropics. In the final remarks, the authors provided information on investigating and managing soil fertility in Africa, an analytical framework for land use change, and the soil biology and fertility research outlook.

This book is a valuable resource for soil scientists, agronomists, students and ecologists with interest primarily in tropical soil biology and fertility. Also, it will be of interest to policy-makers in natural resource management. T. Mbabaliye, Washington State University, Pullman, Washington.

The Pheasants of the World. Biology and Natural History. Second edition. By Paul A. Johnsgard. 1999. Smithsonian Institution Press, Washington D.C. 398 p. US\$50.00 cloth. ISBN 1-56098-839-8.

Last week while driving to my office I heard on the radio news that Washington State was considering ending the fall ringnecked pheasant season early because of low populations of pheasants reported in several areas where their populations are normally high. Sparse cover and wet winter and spring weather, not to mention hunters, can be tough on pheasants in eastern Washington, but I hadn't noticed any particular shortage of pheasants this year following last year's mild winter. And I tend 
to notice pheasants, because some of my earliest memories are of my father making a living, one might say, raising game birds, especially ring-necked pheasants, for our commercial hunting and fishing preserve in northeastern Ohio. So the second edition of Paul A. Johnsgard's The Pheasants of the World recalled personal history beyond its technical edification.

Long a prolific writer of technical, semi-technical and popular books on natural history, Paul Johnsgard has, in this revised second edition, contributed a significant review of the Old World family Phasianidae. This edition updates the first edition published over 15 years ago. Recent research on pheasants has come from research institutions, captive breeding programs, and from commercial and hobbyist breeders of these birds. Dr. Johnsgard has utilized all of these sources.

The Pheasants of the World consists of 2 main sections. Part 1 consists of 8 short chapters covering general ecological topics of the pheasant family including taxonomy, hybridization, growth and development, individual and social behaviors, ecology and population biology, mating behavior and social signaling, reproductive biology, and aviculture and conservation. The discussions here are succinctly semi-technical, but within these 83 pages are found some interesting tabular data, (much of it from the 1940's-1980's), and ultimately, general coverage of pheasant biology and ecology.

Part 2 of the book consists of taxonomic keys, and of species descriptions arranged by genus. Individual species descriptions include varying topics such as other vernacular names, species distributions, descriptions of subspecies, identification features, measurements, habitats, predators, behaviors, avicultural traits, and population status and conservation outlook. Descriptions for some species, such as the common or ring-necked pheasant (Phasianus colchicus) are more detailed, while those for some of the more obscure species are predictably shorter. Many of the 49 species descriptions include hand-drawn illustrations, most by the author. While all pheasants are exotic to the Western Hemisphere, some are long-introduced species (e.g. golden pheasant), while others are still largely indigenous to their Asian areas of origin. Dr. Johnsgard's book includes an appendix of derivations of scientific and vernacular names, an extensive bibliography, and a detailed general index.

As its title and content might suggest, The Pheasants of the World is better characertized as a review of the Phasianidae than as any kind of synthesis. Beyond review of the strikingly ornamental pheasants, the book offers little thermatic message, other than a pensively analytical ambivalence toward captive breeding by zoos and its role in species preservation. Stylistically, the text has the flavor of a review, with abundant, although rarely excessive, citations of literature, and straightforward, scientific narrative. Combination of these features yields a readable reference.

More colorful than the text is section of glossy plates including half- and full-age photographs of living birds and some full-page 19th Century colored plates by Joseph Wolf, both with minimal captions. These plates add much to the book for the casual reader, but The Pheasants of the World will be reference interest to scientists and students, and would seem a must for avicultural hobbyists as well. The book offers much scope and considerable depth to amateur bird breeders, especially to those who specialize in the less common exotic species, individuals who are usually far outside the purview of those who try to commercially raise ring-necked pheasants.

I haven't heard whether Washington State has decided to short- en the ring-necked pheasant season this year. Poor pheasants. Introduced into marginal exotic habitats full of hunters, they often seem to have a rough go of it, and so, for that matter, do some people who raise them for a living. Both certainly, have their pleasant moments, but pleasant and pheasant are a letter away from peasant, simple spelling deletions that, like surviving commercial pheasant farming, are easily accomplished. It is all just a matter of getting the $h$ and $l$ out.-David L. Scarnecchia, Washington State University, Pullman, Washington.

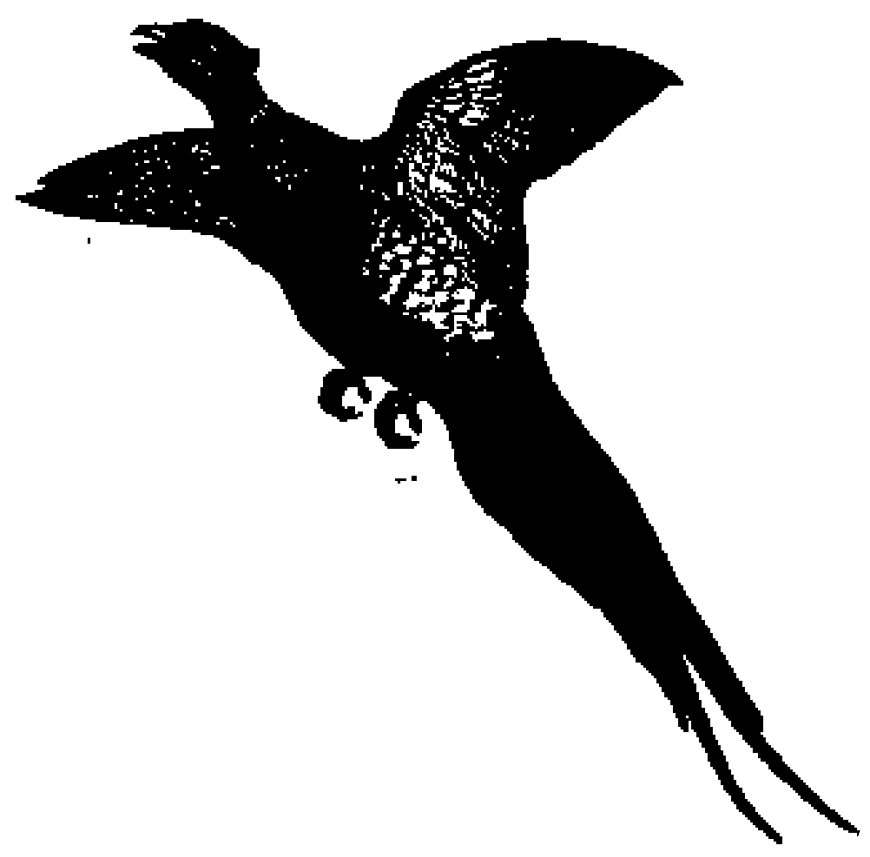




\section{Eligibility}

The Journal of Range Management is a publication for reporting and documenting results of original research and selected invitational papers. Previously published papers are unacceptable and will not be considered for publication. Exceptions to this criterion are research results that were originally published as department research summaries, field station reports, abstracts of presentations, and other obscure and nontechnical handout publications. Manuscripts submitted to the JRM are the property of the Journal until published or released back to the author(s). Manuscripts may not be submitted elsewhere while they are being considered for this journal. Papers not accepted for publication are automatically released to the authors.

\section{Kinds of Manuscripts}

Journal Articles report original findings in Plant Physiology, Animal Nutrition, Ecology, Economics, Hydrology, Wildlife Habitat, Methodology, Taxonomy, Grazing Management, Soils, Land Reclamation (reseeding), and Range Improvement (fire, mechanical chemical). Technical Notes are short articles (usually less than 2 printed pages) reporting unique apparatus and experimental techniques. By invitation of the Editorial Board, a Review or Synthesis Paper may be printed in the journal. Viewpoint articles or Research Observations discussing opinion or philosophical concepts regarding topical material or observational data are acceptable. Such articles are identified by the word viewpoint or observations in the title.

\section{Manuscript Submission}

Contributions are addressed to the Editor, Gary Frasier, Journal of Range Management, 7820 Stag Hollow Road, Loveland, Colorado 80538. Manuscripts are to be prepared according to the instructions in the Journal's Handbook and Style Manual. If the manuscript is to be one of a series, the Editor must be notified. Four copies of the complete manuscript, typed on paper with numbered line spaces are required. Authors may retain original tables and figures until the paper is accepted, and send good quality photocopies for the review process. Receipt of all manuscripts is acknowledged at once, and authors are informed about subsequent steps of review, approval or release, and publication.

Manuscripts that do not follow the directives and style in Journal handbook will be returned to the authors before being reviewed. A manuscript number and submission date will be assigned when the paper is received in the appropriate format.

\section{Manuscript Review}

Manuscripts are forwarded to an Associate Editor, who usually obtains 2 or more additional reviews. Reviewers remain anonymous. These reviewers have the major responsibility for critical evaluation to determine whether or not a manuscript meets scientific and literary standards. Where reviewers disagree, the Associate Editor, at his discretion, may obtain additional reviews before accepting or rejecting a manuscript. The Associate Editor may also elect to return to the author those manuscripts that require revision to meet format criteria before the Journal review.

The Associate Editor sends approved manuscripts, with recommendations for publication, to the Editor, who notifies the author of a projected publication date. Manuscripts found inappropriate for the JRM are released to the author by the Associate Editor. Manuscripts returned to an author for revision are returned to the Associate Editor for final accept ability of the revision. Revisions not returned within 6 months, are considered terminated. Authors who consider that their manuscript has received an unsatisfactory review may file an appeal with the Editor. The Editor then may select another Associate Editor to review the appeal. The Associate Editor reviewing the appeal will be provided with copies of an correspondence relating to the original review of the manuscript. If the appeal is sustained, a new review of the manuscript may be implemented at the discretion of the Editor.

Authors should feel free to contact the Associate Editor assigned to their manuscript at any stage of the review process: to find out where the paper is in the process; to ask questions about reviewer comments; to ask for clarification or options if a paper has been rejected.

\section{Page Proofs}

Page proofs are provided to give the author a final opportunity to make corrections of errors caused by editing and production. Authors will be charged when extensive revision is required because of author changes, even if page charges are not assessed for the article. One author per paper will receive page proofs. These are to be returned to the Production Editor, 445 Union Blvd., Suite 230, Lakewood, Colorado 80228, within 48 hours after being received. If a problem arises that makes this impossible, authors or their designates are asked to contact the Production Editor immediately, or production and publication may proceed without the author's approval of his edited manuscript.

\section{Page Charges and Reprint Orders}

Authors are expected to pay current page charges. Since most research is funded for publication, it will be assumed that the authors are able to pay page charges unless they indicate otherwise in writing, when submitting a manuscript. When funds are unavailable to an author, no page charges will be assessed. Only the Editor will have knowledge of fund status of page charges; the Associate Editors and reviewers will accept or reject a manuscript on content only.

An order form for reprints is sent to one author with the page proofs. Information as to price and procedure are provided at that time. The minimum order is 100; no reprints are provided free of charge.

\section{Basic Writing Style}

Every paper should be written accurately, clearly, and concisely. It should lead the reader from a clear statement of purpose through materials and methods, results, and to discussion. The data should be reported in coherent sequence, with a sufficient number of tables, drawings, and photographs to clarify the text and to reduce the amount of discussion. Tables, graphs, and narrative should not duplicate each other.

Authors should have manuscripts thoroughly reviewed by colleagues in their own institution and elsewhere before submitting them. Peer review before submission insures that publications will present significant new information or interpretation of previous data and will speed $J R M$ review process.

Particular attention should be given to literature cited: names of authors, date of publication, abbreviations or names of journals, titles, volumes, and page numbers.

It is not the task of Associate Editors or Journal reviewers to edit poorly prepared papers or to correct readily detectable errors. Papers not properly prepared will be returned to the author. 